\author{
ZENTRUM \\ FÜR BIODIVERSITÄT UND NACHHALTIGE LANDNUTZUNG \\ SEKTION \\ BIODIVERSITÄT, ÖKOLOGIE UND NATURSCHUTZ \\ - Centre Of Biodiversity AND SustaINABLE LAND USE - \\ SECTION: BIODIVERSITY, ECOLOGY AND NATURE CONSERVATION
}

\title{
Altitude, litter quality and availability of root derived resources as determinants of decomposition processes and soil microarthropod community composition in tropical montane rainforests in Southern Ecuador
}

Dissertation zur Erlangung des Doktorgrades der Mathematisch-Naturwissenschaftlichen Fakultäten der Georg-August-Universität Göttingen

vorgelegt von

Diplom Biologin

Franca Marian

aus

Offenbach 
Referentin/Referent: Prof. Dr. Stefan Scheu Korreferentin/Korreferent: Prof. Dr. Mark Maraun Tag der mündlichen Prüfung: 19.08.2016 
„Das ist überall dasselbe wo es zu wenig Licht gibt. Da spielt die Natur verrückt, weil sie sich unbeobachtet fühlt." aus „Rumo \& Die Wunder im Dunkeln“ von Walter Moers 


\section{Contents}

Summary

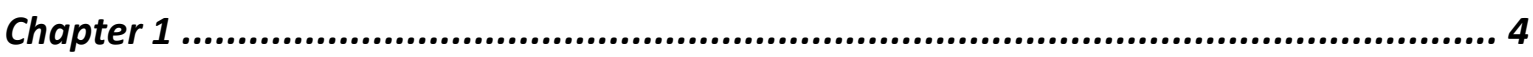

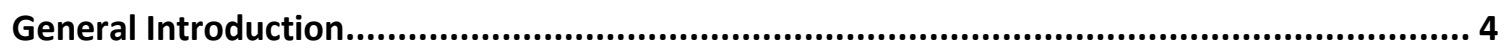

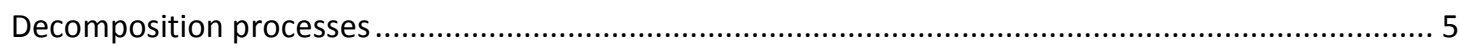

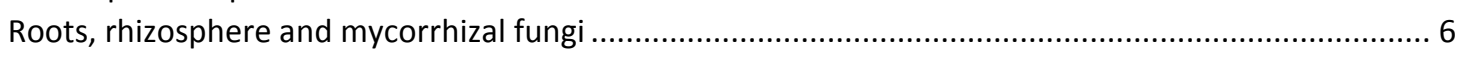

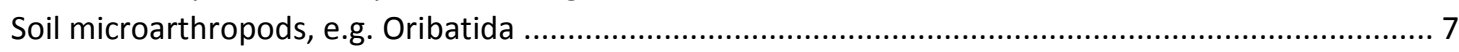

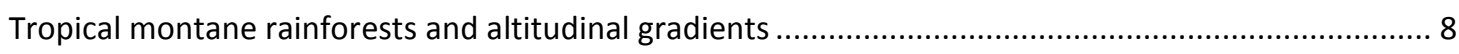

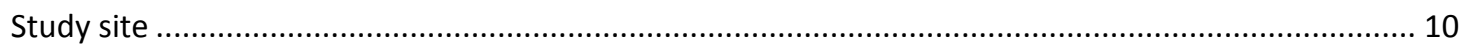

Objectives and chapter outline............................................................................................ 11

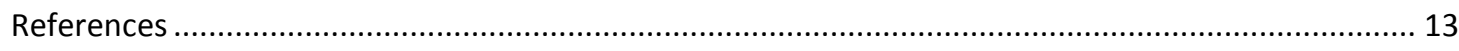

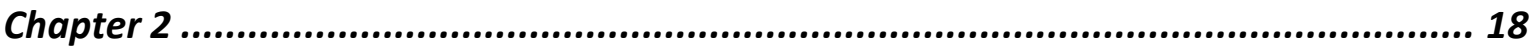

Decomposition of leaf and root litter in tropical montane rainforests suggests strong nutrient

limitation resulting in long-term carbon sequestration.................................................. 18

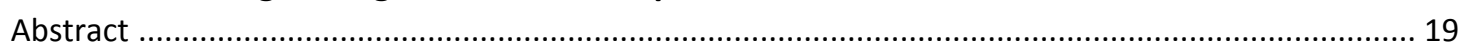

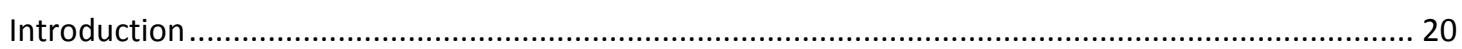

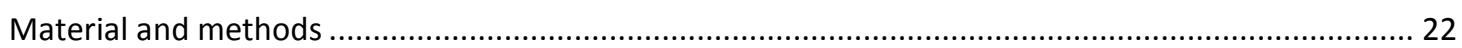

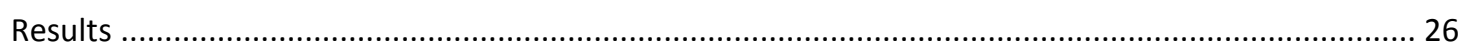

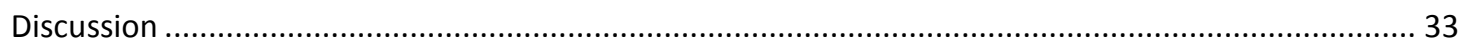

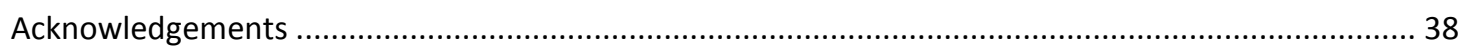

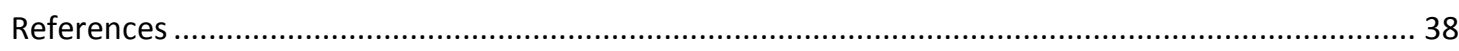

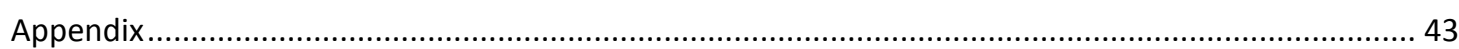

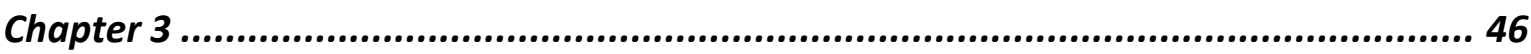

Changes in the structure of soil animal communities in decomposing leaf and root litter in tropical montane rainforests: Influence of altitude and litter origin......................................46

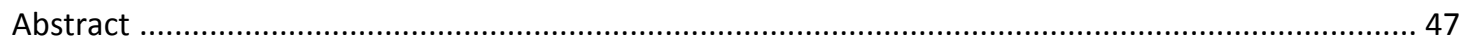

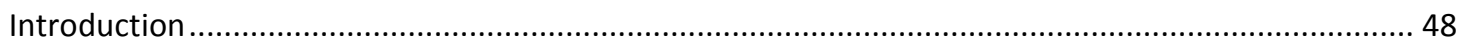

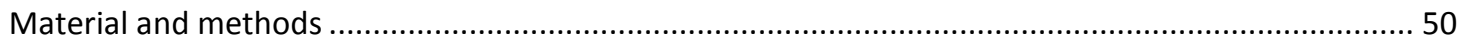

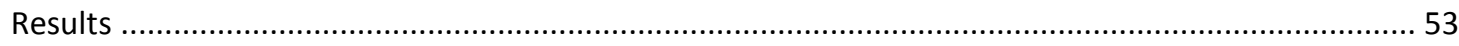

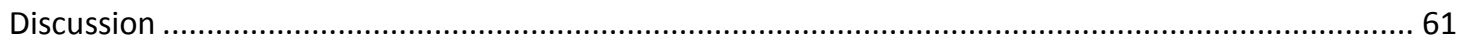

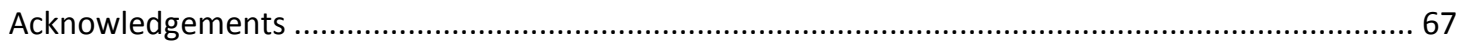

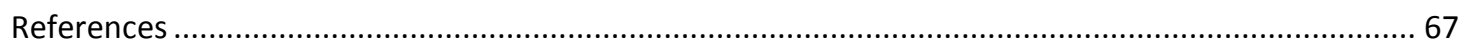

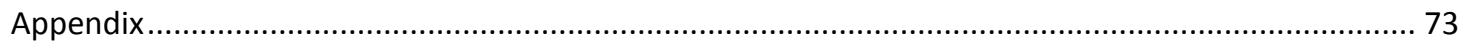

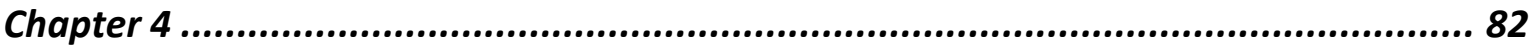

Roots, mycorrhizal fungi and altitude as determinants of litter decomposition and soil animal

communities in tropical montane rainforests.................................................................. 82

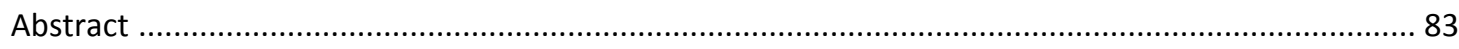

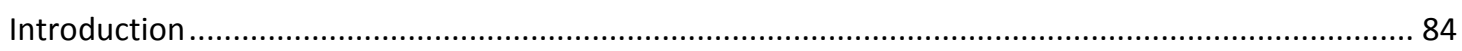

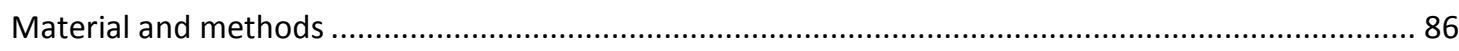

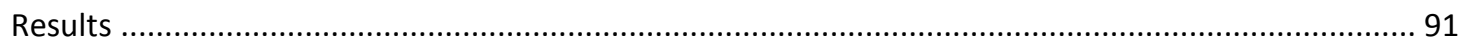

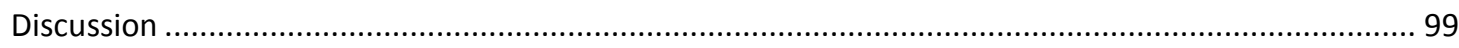

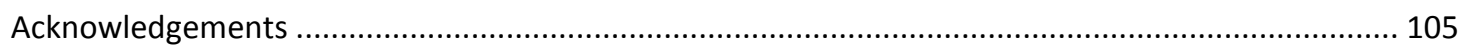

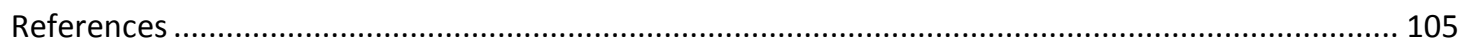

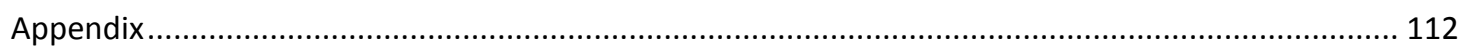

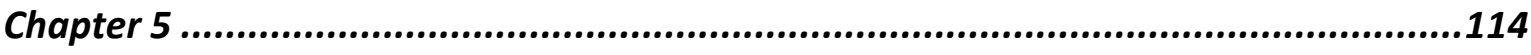

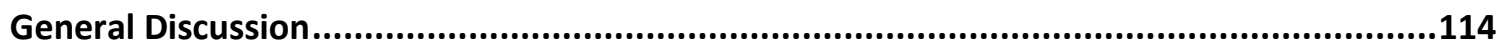


Regulatory forces of litter decomposition

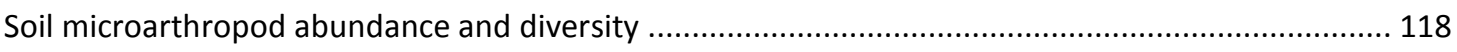

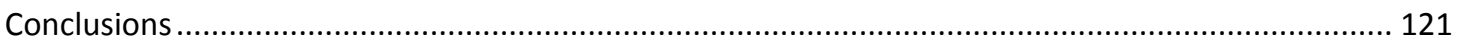

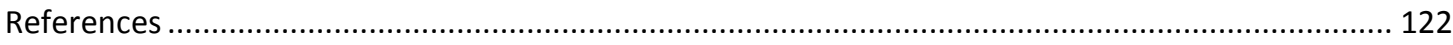

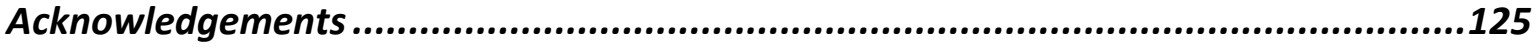

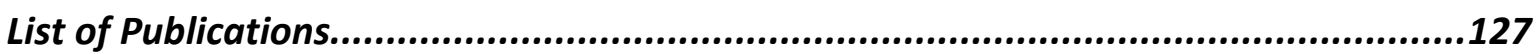

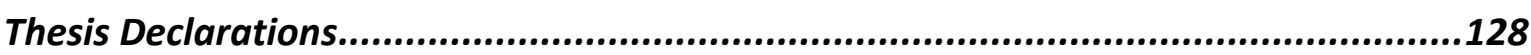

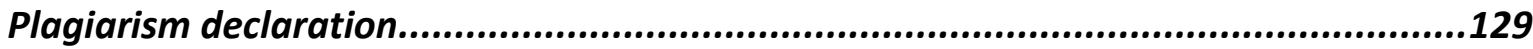




\section{Summary}

Decomposition processes in the high tropical Andes are complex and influenced by a variety of biotic and abiotic factors. Tropical montane rainforests of the high Andes harbour large stocks of dead organic material and little is known on the regulatory forces responsible for this accumulation of carbon. Litter quality, climate and the decomposer community are known from other systems as the main factors controlling decomposition rates. Microarthropods play a major role in regulating decomposition processes due to the impact they have on their surrounding habitat. They are known to regulate organic matter turnover and influence nutrient cycling via direct and indirect processing of organic matter entering the soil system as both litter fall and root exudates. However, there is a lack of knowledge on interrelationships between litter decomposition and the structure of soil microarthropod communities in tropical montane rainforests.

This thesis focuses on disentangling the relative importance of regulatory forces, e.g. litter quality and local biotic and abiotic conditions, in regulating long term decomposition processes and variations in the microbial and microarthropod community composition. Further, I investigated the role of root derived resources in structuring the soil fauna community and in regulating decomposition processes. The studies were performed as field experiments along an altitudinal gradient from 1000 to 2000 to $3000 \mathrm{~m}$ in a tropical montane rainforest in Southern Ecuador.

In the first study, presented in Chapter 2, I investigated the influence of litter quality, i.e. litter origin, and altitude on long term decomposition rates of both leaf and root litter in the tropical montane rainforests. The results suggested that the pronounced accumulation of dead organic material at higher altitudes at least in part is caused by reduced or even ceasing decomposition rates after 12 months. The study demonstrated that litter quality is far less important in controlling decomposition rates than previously assumed. Rather, site specific and altitude dependant biotic and abiotic factors are most relevant. Presumably, the observed long term decomposition patterns are caused by different forest floor types at the investigated altitudes as well as different rhizosphere interactions between plants and the belowground community. Litter materials are generally poor in nitrogen and do not allow effective decomposition by saprotrophic microorganisms and this applies in particular to condensed litter compounds such as lignin. The results suggest that poor nutrient conditions in organic litter layers at high altitudes inhibit microorganisms to decompose litter materials due to the lack of contact to nutrients in the mineral soil. Presumably, restriction of microorganisms to root derived resources in the organic layer results in a closer linkage between plants and the decomposer community exploiting litter resources and this linkage is most pronounced at higher altitudes.

Parallel to decomposition processes, in a second study I investigated changes in the abundance and diversity of the most abundant microarthropod groups in soil, i.e. Oribatida and Collembola, as well 
as Oribatida diversity and species composition, during litter decomposition (Chapter 3). As in the first study presented in Chapter 2, I investigated the role of litter quality (i.e. litter origin), altitude and litter type (root and leaf litter) as driving factors in order to quantify their role in regulating the composition and abundance of the microarthropod community. The parallel investigation of decomposition processes and microarthropods in one experiment allowed linking driving factors of both litter decomposition and microarthropod community composition. Similar to the results of the first study quality of litter material was of little importance as driving force for the composition of the microarthropod community. Rather, factors changing with altitude were most important, with both the abundance of microarthropods as well as the diversity of Oribatida decreasing with increasing altitude. Decomposition stage also strongly affected the soil microarthropod fauna with the changes in abundance and diversity occurring over time being closely associated with changes in the speed of litter decomposition and associated changes in microorganisms. Surprisingly however, microarthropods were unable to benefit from the flourishing microbial community at the early decomposition stage, potentially due to the presence of plant secondary compounds such as phenols, and the dominance of mycorrhizal fungi. At later stages microarthropods appear to benefit from the dominance of saprotrophic microorganisms decomposing more recalcitrant litter compounds, either by feeding on these microorganisms directly or by indirectly benefiting from the conditioning of the litter by microbial enzyme production.

The results of the first two studies suggest that in particular at higher altitude root-derived resources are major drivers of decomposition rates, microorganisms and soil microarthropods in the investigated tropical montane rainforests. The third experiment, presented in Chapter 4, therefore focused on investigating the effect of the exclusion of roots and mycorrhizal hyphae on litter decomposition and soil fauna community composition. The results from this study suggested that mycorrhizal fungi and saprotrophic microorganisms compete for litter-derived resources, with mycorrhizal fungi suppressing the activity of saprotrophic microorganisms at each of the investigated altitudes. Collembola were the only microarthropods to benefit from mycorrhiza exclusion and reduced competition between mycorrhizal fungi and saprotrophic microorganisms, indicating that they depend on litter-derived resources. Total soil microarthropod density as well as Oribatida diversity, however, were reduced if roots and mycorrhizal hyphae were excluded, highlighting the importance of root-derived resources for fuelling soil food webs. Along the altitudinal gradient variations in microarthropod abundance and decomposition rates did not fit the patterns observed in the studies presented in Chapters 2 and 3 suggesting that plant-soil fauna interactions influencing belowground ecosystem processes vary with season, e.g. with drought or drought related changes, especially at lower altitude. 
By highlighting the importance of altitude and root derived resources for long term decomposition processes and the belowground community structure the results of this thesis improved the understanding of regulatory forces controlling decomposition processes as well as microarthropod abundance and diversity in tropical montane rainforests. 


\section{Chapter 1}

\section{General Introduction}
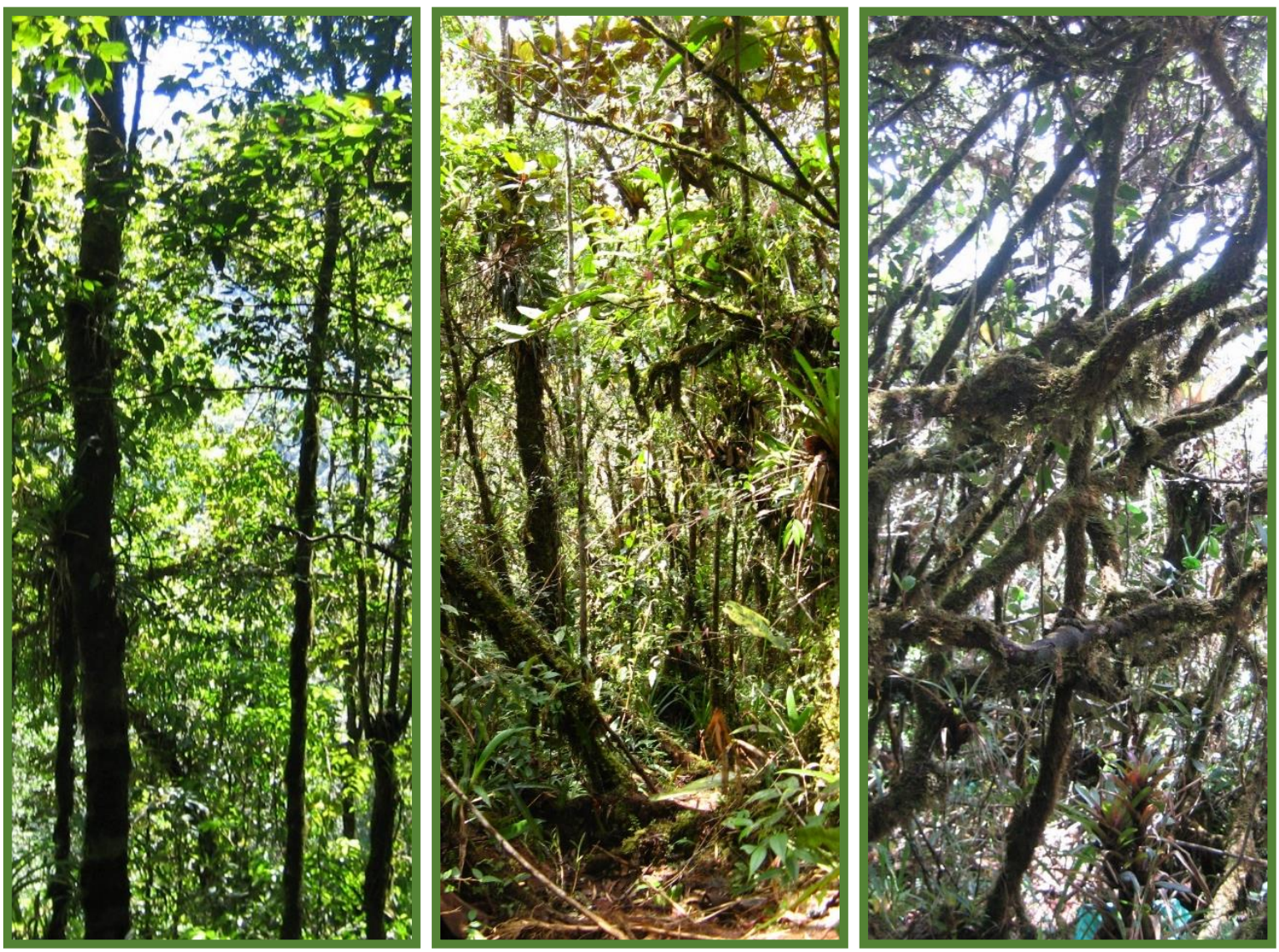


\section{Decomposition processes}

Decomposition is one of the most important processes in terrestrial ecosystems, with between 80 and $90 \%$ of the aboveground net primary production entering the soil as leaf and root litter (McNaughton et al., 1989; Bardgett, 2005). Under unfavourable environmental conditions undecomposed plant material can accumulate resulting in extensive amounts of carbon (C) being stored. Especially in peatlands, tundra and the boreal zone an estimated one-third of the global C stock is accumulated in large organic layers (Post et al., 1982; Gorham, 1991). The release of this C in either gaseous or aqueous form may contribute substantially to the increasing $\mathrm{CO}_{2}$ concentrations in the atmosphere (Cox et al., 2013). Current models projecting the response of soil organic $\mathrm{C}$ pools to climate change and elevated atmospheric $\mathrm{CO}_{2}$ levels are still uncertain whether C storage will increase or decline and more data on regulatory forces of decomposition processes are needed (Cox et al., 2013; Todd-Brown et al., 2014). Processes and interactions involved in decomposition are manifold and complex. It is almost impossible to consider all possible influences when investigating decomposition processes in natural systems (Berg \& McClaugherty, 2008), but litter quality, climate and the decomposer community have been identified as the most important drivers (Kirschbaum, 1995; Coûteaux et al., 2002; Davidson \& Janssens, 2006; Berg, 2014). Over the course of decomposition the chemical composition of litter material changes both through import and export of nutrients and the synthesis of new organic compounds (Berg \& McClaugherty, 2008). Litter mass loss during decomposition is due to $\mathrm{CO}_{2}$ released via microbial respiration, fragmentation of litter material by larger decomposer fauna as well as leaching of both $\mathrm{C}$ and nutrients. Over the course of decomposition complex litter compounds (e.g. proteins, lignin, cellulose etc.) are broken down by the microbial community through the release of extracellular enzymes producing smaller compounds that can be assimilated by the microorganisms (Bardgett, 2005). Despite being taken up in large by microorganisms, plants in part may also assimilate organic compounds such as amino acids. Most plants, however, are unable to obtain organic nutrients and therefore rely on microorganisms, which release inorganic $\mathrm{N}$ (ammonium) after their own nutritional requirements are fulfilled. This net $\mathrm{N}$ mineralization is assumed to only occur in ecosystems where the decomposing material contains $\mathrm{C}-$ to- $\mathrm{N}$ ratios lower than 25 (Hodge et al., 2000). Decomposition processes are known to undergo different stages with the early stage being characterized by fast mass loss through leaching of soluble compounds and decomposition of holocellulose while in the later phases of decomposition the rate of mass and $\mathrm{C}$ loss slows down and is dominated by the degradation of lignified litter compounds (Berg \& McClaugherty, 2008; Berg, 2014). With the changes in litter quality over the course of decomposition also the importance of litter as a basal resource for the soil food web varies not only between habitats but also over time, with litter in later stages of decomposition becoming more palatable for soil mesofauna 
consumers (Bardgett, 2005). Next to litter decomposition products also resources provided via the root pathway play an important role in structuring the soil food web.

\section{Roots, rhizosphere and mycorrhizal fungi}

Plant roots modify both physical and chemical properties of the soil by structuring the soil and organic material surrounding them, the release of nutrients via root exudates and through their death and decomposition (Bardgett, 2005; Cesarz et al., 2013; Eissfeller et al., 2013). The rhizosphere; i.e. the area closely surrounding the root surface, has long been recognised as an area of high microbial activity in soil due to the release of root exudates and consequently very close interactions between roots and soil microorganisms (Hiltner, 1904; Gregory, 2006). Root exudates are a high quality resource consisting of ions, water, mucilage and many low molecular primary and secondary metabolites containing C (Bertin et al., 2003; Bais et al., 2006). They are relevant for sustaining the soil microbial community in close proximity to the root surface where microbial biomass is significantly increased compared to the bulk soil (Whipps \& Lynch, 1983; Bais et al., 2006; Dennis et al., 2010). C from the plant not only reaches the soil via root exudates, but also a large proportion of plant assimilated $\mathrm{C}$ is transported into mycorrhizal fungi, which form mutualistic associations with plants (Farrar et al., 2003). Mycorrhizal fungi therefore function as a sink of plant C (Averill et al., 2014) and gain an advantage in competition with the soil microbial community. In return plants receive nitrogen $(\mathrm{N})$ as well as phosphorus $(\mathrm{P})$ from mycorrhizal fungi with this interaction being especially close in nutrient ( $\mathrm{N}$ and $\mathrm{P}$ ) limited ecosystems (Johnson et al., 2003). Plant species associated with mycorrhizal fungi comprise around $95 \%$ of all vascular plants (Smith \& Read, 2008) and the enhanced nutrient supply increases their competitive strength as well as the growth rate and improves plant fitness (Bardgett, 2005). Mycorrhizal fungi can be divided into different types according to their growth form within the root, with ectomycorrhizal (EM), arbuscular mycorrhizal (AM) and ericoid mycorrhizal fungi being the most abundant types. The more primitive AM fungi are dominant forming associations with up to $80-90 \%$ of plant species, including grasses, herbs, crops and trees (Mosse, 1973). AM fungi reproduce asexually and cannot be cultivated without their host. They grow within their hosts root cortical cells, forming tree like structures, the arbuscules, which are thought to be the area in which $\mathrm{C}$ and nutrients are exchanged between plant and fungus (Bardgett, 2005). EM fungi on the other hand are most abundant in temperate and boreal forest ecosystems where they form associations with shrubs and trees, especially coniferous species. They do not grow inside their hosts cells but rather form either the intercellular Hartig net or a mantle of fungal tissue covering the entire root (Smith \& Read, 2008). Ericoid mycorrhizal fungi only form associations with ericaceous plants, which typically grow in highly organic, nutrient poor soils, mainly of the alpine and tundra regions (Bardgett, 2005). The 
ericoid fungus grows inside the root cortical cells similar to the AM fungi, but without forming arbuscules. While EM and ericoid mycorrhizal fungi have saprotrophic capabilities, AM fungi were in the past assumed to be unable to take up organic forms of $\mathrm{N}$, but have recently been suggested to in fact also possess saprotrophic capabilities and enhance decomposition rates (Hodge et al., 2001; Hodge \& Fitter, 2010). Both EM and AM fungi can therefore influence decomposition processes (Gadgil \& Gadgil, 1971; Hodge et al., 2001; Bending, 2003; Nuccio et al., 2013; Leifheit et al., 2015) with their functioning in litter decomposition being closely associated with the activity and community structure of saprotrophic microorganisms (Leigh et al., 2011). Depending on the environmental conditions, mycorrhizal fungi can either slow down or enhance decomposition processes (Gadgil \& Gadgil, 1971; Olsson et al., 1996; Hodge et al., 2001; Hodge \& Fitter, 2010) with slowed down decomposition presumably being caused by mycorrhizal fungi competing with saprotrophic bacteria and fungi for nutrients (mainly nitrogen; Gadgil and Gadgil, 1971; Leigh et al., 2011) as well as for water (Bending, 2003). AM fungi have also been shown to form close interactions with the soil fauna community, e.g. the microbial community and protozoans, increasing $\mathrm{N}$ uptake of plants via the microbial loop (Coleman, 1994; Koller et al., 2013) as well as soil microarthropods grazing on extra-radical hyphae of AM fungi (Ngosong et al., 2014).

\section{Soil microarthropods, e.g. Oribatida}

Soil microarthropods are highly diverse and abundant in soils of virtually any ecosystem and climatic zone (Bardgett, 2005). Together with other soil fauna groups they impact their surrounding habitat by regulating organic matter turnover and nutrient cycling via processing of organic matter that is entering the soil system via litter fall and root exudates (Bardgett, 2005). The effect of soil microarthropods on decomposition processes may be direct by shredding litter material, but also indirect via trophic interactions with the fungal and bacterial community (Moore et al., 1988; Maraun et al., 1998; Pollierer et al., 2012; Zieger et al., 2015). Recently soil microarthropods have been recognised to also largely depend on root-derived resources (Pollierer et al., 2007; Zieger et al., 2015). The two most abundant groups of soil microarthropods are Collembola and Acari. Both of these groups interact closely with bacteria and fungi and comprise a wide spectrum of species of different trophic levels including primary and secondary decomposers and in part also predators (Scheu, 2002; Schneider et al., 2004a; Chahartaghi et al., 2005). Although soil microarthropods are present in virtually any soil, both their abundance and diversity varies between ecosystems as well as within few centimetres of soil (Ettema \& Wardle, 2002). The reasons for the high spatial heterogeneity in the structure of soil microarthropod communities still are little understood, but likely are due to both variations in biotic and abiotic factors such as local climatic conditions and litter quality (Coûteaux et al., 1995; Wardle et al., 2006; Berg \& McClaugherty, 2008). 
With around 55,000 described species and an estimated total species number between 500,000 and 1,000,000 (Krantz et al., 2009) Acari are one of the most diverse and also oldest microarthropod groups (Fisher et al., 2013). While earliest fossil records of Acari were found in Devonian sediment ( 380 million years ago) (Shear et al., 1984; Norton et al., 1988) molecular clock analysis dates the origins of Acari as far back as 570 million years (Schaefer et al., 2010). Acari are extremely successful in colonising a wide spectrum of terrestrial, aquatic and marine habitats (Krantz et al., 2009). With nearly 10,000 described species (Subias, 2015) and an estimated total of 110,000 species (Walter \& Proctor, 2013) the Oribatida are the most species-rich subgroup within the Acari (Krantz et al., 2009). In soils rich in organic material Oribatida are often the most abundant microarthropod group (Krantz et al., 2009), reaching densities of up to 200,000 individuals per square meter in temperate coniferous forests (Maraun \& Scheu, 2000). Oribatida were, for a long time, assumed to be predominantly decomposers feeding on dead organic material. In recent years closer analysis of their feeding biology via gut content and stable isotope analysis as well as laboratory feeding experiments have shown that Oribatida also feed on lichens and algae, nematodes and root-derived resources, therefore ranging over three to four trophic levels (Schneider et al., 2004b; Erdmann et al., 2007; Pollierer et al., 2007). With a live span of typically between one to two years and low reproductive output Oribatida invest strongly in defence mechanisms, such as camouflage, strong sclerotization, defensive glands and protective structures and are as a result well defended and not preyed upon by mesofauna predators (Peschel et al., 2006; Schneider \& Maraun, 2009; Heethoff et al., 2011; Heethoff \& Raspotnig, 2012). Parthenogenesis is more abundant in Oribatida than in any other Acari (Krantz et al., 2009), although the percentage of parthenogenetic species varies between habitats. In tropical regions where Oribatida are the most abundant soil microarthropods (Heneghan et al., 1999; Franklin et al., 2004; Illig et al., 2010) even so their diversity does not appear to increase towards the tropics (Maraun et al., 2007) and many species are not yet described (Ermilov et al., 2013a,b,c), only around $30 \%$ of species are parthenogenetic (Maraun et al., 2013) compared to between 60-80 \% in temperate and boreal forest (Maraun et al., 2003; Fischer et al., 2010).

\section{Tropical montane rainforests and altitudinal gradients}

The term tropical rainforest was first introduced in 1898 by the German botanist A.F.W. Schimper, describing all forests in the humid tropical regions. Today the term tropical rainforest is mainly used to describe evergreen forests occurring in regions of constantly high temperatures with less than five degree variation between mean daily temperatures and high amounts of precipitation ( $\geq 100 \mathrm{~mm}$ per month) throughout the year (Whitmore, 1990). Tropical rainforests are found on all three land regions around the equator, i.e. Middle and South America, Sub Saharan Africa and 
Southeast Asia. The largest are the neotropical rainforests of South America covering $4 \times 10^{6} \mathrm{~km}^{2}$ and making up half of the world's rainforest areas (Whitmore, 1990). All tropical rainforests are exceptionally species rich, containing most of the world's higher plants (Pitman \& Jørgensen, 2002) as well as a high diversity in both vertebrate and invertebrate fauna. In different environments tropical rainforests possess individual compositions, structures and physiognomy and are therefore often separated into forest types according to the conditions under which they occur, e.g. swamp forests, peat forests, coastal forests (i.e. mangroves), lowland forests and montane forests. Montane rainforests are found in all major tropical forest regions, although in Africa they only occur in smaller local patches. They are especially species rich (Myers et al., 2000) due to the progressively changing abiotic conditions along altitudinal gradients. Changes in both biodiversity and abundance have been widely studied along altitudinal gradients for different taxa and in a wide range of ecosystems (Richardson et al., 2005; Sanders et al., 2009; Sundqvist et al., 2013; Willig \& Presley, 2015). Altitudinal gradients provide the opportunity to investigate the influence of changing abiotic conditions on fauna and flora composition and can help understanding consequences of climate change. Precipitation, soil moisture, cloud coverage, solar radiation as well as mean annual air temperature generally vary with altitude, leading to some predictable vegetation patterns that can be observed in all tropical montane rainforests. The altitude in which the different forest types occur depends on the size of the mountain, with forest zones being higher on larger mountains (Bruijnzeel \& Hamilton, 2000). This phenomenon is called the "Massenhebungseffekt" and is due to differences in cloud coverage and temperature, depending on the height and surface area of the mountain (Ghazoul \& Sheil, 2010). Forest types change from lower montane forests to lower montane cloud forests followed by upper montane and finally subalpine cloud forests, also called dwarf forests or "elfine woodland" (Ghazoul \& Sheil, 2010). These subalpine dwarf forests are especially common in the high tropical Andes occurring above 2,800 to 3,000 $\mathrm{m}$ a.s.l. With increasing altitude the tree canopy gets lower and plant species diversity generally decreases; the abundance of mosses and bryophytes increases while lianas disappear at higher altitudes (Ghazoul \& Sheil, 2010). Above the tree line which can be as high as 3,900 $\mathrm{m}$ a.s.l. the forests give way to alpine vegetation consisting of grasslands, heath, tundra bogs and meadows (Ghazoul \& Sheil, 2010). In the tropical Andes this vegetation zone is called "Paramo". The Tropical Andes are one of the world's biodiversity hotspots (Myers et al., 2000; Brehm et al., 2008). Myers et al. (2000) defined these hotspots as areas containing exceptionally high numbers of endemic species, focusing on aboveground animal and plant species (Henderson et al., 1991; Myers et al., 2000; Barthlott et al., 2005), still there is far less known about the belowground system. While in tropical lowland forests macrofauna decomposers such as termites and earthworms are abundant and play an important role as primary decomposers improving the accessibility of litter material for bacteria 
and fungi by shredding the litter, in montane rainforests these macro-decomposers are rare (Anichkin et al., 2007; Illig et al., 2008) and their place is supposedly filled by mesofauna species (Illig et al., 2005) such as the highly abundant Oribatida (see above).

\section{Study site}

Studies of the present thesis were conducted on the eastern slope of the tropical Andes in southern Ecuador, with three study sites along an altitudinal gradient at 1000, 2000 and $3000 \mathrm{~m}$ a.s.l. The study sites are in the northern part of the Podocarpus National Park where slopes are moderately steep with $26^{\circ}-31^{\circ}$ (Moser et al., 2007) and covered with mostly undisturbed montane rainforest (Homeier et al., 2002). The site at $1000 \mathrm{~m}$ (Bombuscaro, S04 $06^{\prime} 54^{\prime \prime}, \mathrm{W} 78^{\circ} 58^{\prime} 02^{\prime \prime}$ ) is located south of the city Zamora in the valley of the Rio Bombuscaro. The site at $2000 \mathrm{~m}$ (San Francisco, $\left.\mathrm{S}^{\circ} 58^{\prime} 18^{\prime \prime}, \mathrm{W} 79^{\circ} 4^{\prime} 45^{\prime \prime}\right)$ is part of a private reserve, the Reserva Biologica San Francisco, which includes an area of 9 ha on the flank of the valley of the Rio San Francisco on the northern border of the Podocarpus National Park. The site at 3000 m (Cajanuma, S04 $06^{\prime} 711^{\prime \prime}$, W79 $10^{\prime} 58^{\prime \prime}$ ) is located south of the city Loja at the north-west gate of the Podocarpus National Park.

With 8-10 humid months per year the region has a semi humid climate. Mean annual rainfall increases from 2230 and $1950 \mathrm{~mm}$ at 1000 and $2000 \mathrm{~m}$, respectively, to $4500 \mathrm{~mm}$ at $3000 \mathrm{~m}$ (Moser et al., 2007), while the mean annual air temperature decreases with increasing altitude from 19.4 to 15.7 to $9.4^{\circ} \mathrm{C}$ at 1000,2000 and $3000 \mathrm{~m}$, respectively. Soil pH also gradually decreases with increasing altitude from 3.94 to 3.52 to 2.86 at 1000, 2000 and 3000 m, respectively (Moser et al., 2007). With increasing altitude the mean soil moisture in the organic layer increases to 45.3 vol.\% at $3000 \mathrm{~m}$ as compared to 9.9 and 11.6 vol.\% at 1000 and $2000 \mathrm{~m}$, respectively (Leuschner et al., 2007). Biotic conditions also change along the altitudinal gradient. Mean tree height decreases from 15.6 to 10.1 to $5.2 \mathrm{~m}$ at 1000,2000 and $3000 \mathrm{~m}$, respectively, while thickness of organic layers as well as fine root biomass increases from $48 \mathrm{~mm}$ and $2.7 \mathrm{tha}^{-1}$ to $305 \mathrm{~mm}$ and $6.2 \mathrm{t}$ ha-1 to $435 \mathrm{~mm}$ and $10.8 \mathrm{t} \mathrm{ha}^{-1}$ at the respective sites (Moser et al., 2007; Graefe et al., 2008). At $1000 \mathrm{~m}$ a thin litter layer overlays the mineral soil (Ah horizon), i.e. $\mathrm{F}$ and $\mathrm{H}$ layers are lacking; in contrast, at 2000 and $3000 \mathrm{~m}$ the leaf litter overlays thick organic layers comprising predominantly of $\mathrm{F}$ material. Soil types at 1000, 2000 and $3000 \mathrm{~m}$ are predominantly Alumic Acrisols, Gley Cambisols and Podzols, respectively (Moser et al., 2007). 


\section{Objectives and chapter outline}

This thesis aims at improving the knowledge about interactions between above- and belowground compartments of ecosystems in a tropical montane rainforest in Southern Ecuador focusing on the controlling forces influencing decomposition processes at different altitudes. Chapters 2 to 4 are all field experiments with Chapter 2 aiming at quantifying the relative importance of litter quality and abiotic conditions on long term decomposition processes of leaf and root litter and Chapter 3 in parallel investigating the colonisation of leaf and root litter material by microorganisms and soil microarthropods. The field experiment presented in Chapter 4 investigates the role of mycorrhizal fungi and root-derived resources for belowground food web interactions in tropical forest ecosystems.

The main hypotheses of this thesis are as follows:

(1) Decomposition rates as well as changes in $\mathrm{C}$ and $\mathrm{N}$ concentrations in decomposing litter material are driven by both biotic and abiotic site specific conditions as well as the quality of the litter material, i.e. the origin of litter from rainforests of different altitude.

(2) The abundance of the Collembola and Acari as well as Oribatida diversity decreases along the altitudinal gradient and differs between leaf and root litter.

(3) Abundance and diversity of the soil fauna community vary with litter quality and with the degree to which the litter material is decomposed.

(4) Root-derived resources influence decomposition processes and the abundance and diversity of soil microarthropods.

The content of the three chapters can be summarized as follows:

In Chapter 2 we investigated the effect of altitude, litter origin and litter type on long term decomposition rates and microorganisms in a tropical montane rainforest in southern Ecuador. Leaf litter from three abundant tree species and roots of different diameter were collected from three sites along an altitudinal gradient $(1000,2000,3000 \mathrm{~m})$, placed in litterbags and incubated for 6 , 12, 24, 36 and 48 months. Altitude and time were the main factors driving litter decomposition, while origin and therefore quality of the litter material was of minor importance. At 2000 and $3000 \mathrm{~m}$ decomposition of litter declined for 12 months reaching a limit value of $50 \%$ of initial not decomposing further from 12 to 24 months; after 36 months decomposition commenced, but at low rates resulting in an average of $37.9 \%$ and $44.4 \%$ of initial remaining after 48 months. In contrast, at 1000 m decomposition continued for 48 months with only $10.9 \%$ of the initial litter remaining. Changes in decomposition rates were paralleled by changes in the microbial community 
with microbial biomass decreasing after 24 months at 2000 and 3000 m, while varying little at $1000 \mathrm{~m}$. The results suggest that low nutrient supply at high altitudes inhibit decomposition processes resulting in the sequestration of carbon in thick organic layers.

Chapter 3 presents further results from the experimental setup described in Chapter 2. Parallel to the results presented in Chapter 2 the effect of the same parameters (i.e. altitude, litter origin and litter type) on soil microarthropod communities over the course of long term decomposition processes in a tropical montane rainforest in southern Ecuador were investigated (see above). Density and diversity of soil microarthropods (i.e. Acari and Collembola) decreased with increasing altitude and varied with the degree to which the litter was decomposed rather than with litter origin and therefore quality of the litter material. Species composition of Oribatida varied strongly between altitudes, with few species overlapping between altitudes. This suggests origin and therefore quality of litter material to be of little importance as driving force for the composition of the microarthropod community of tropical montane rainforests. Factors changing with altitude, such as temperature and soil $\mathrm{pH}$, as well as decomposition stage and associated changes in the microbial community and interactions with mycorrhizal fungi and litter-derived resources are much more important.

Results of the experiments presented in Chapters 2 and 3 suggested a strong influence of rootderived resources on decomposition rates, microorganisms and soil microarthropods in the investigated tropical montane rainforest. Therefore, in Chapter 4 we investigated the role of roots and mycorrhizal fungi on these parameters. We conducted an experiment at the three altitudes (1000, 2000 and $3000 \mathrm{~m}$ a.s.l.) and placed microcosms with openings covered with different mesh sizes ( $4 \mathrm{~mm}, 45 \mu \mathrm{m}$ and closed) to manipulate the accessibility by roots and mycorrhizal fungi in the field. The microcosms contained an undisturbed soil core and a litter layer consisting of litter from the three abundant tree species at each altitude. Decomposition rates, C-to-N ratio, water content, microbial parameters and microarthropod abundance differed between the three altitudes. While water content and $\mathrm{C}$-to- $\mathrm{N}$ ratio were lower and microbial biomass was increased in the litter layer at the lowest altitude, decomposition rate and microarthropod abundance were at a maximum at the intermediate altitude. The exclusion of roots and mycorrhizal fungi did not affect the decomposition rate but lead to a decrease in Oribatida abundance and diversity, while Collembola abundance was increased in closed microcosms. Oribatida community composition varied between the altitudes. The results of Chapter 4 indicate that root- and mycorrhiza-derived resources are of similar importance at each of the three investigated altitudes. Nutrient limitation presumably resulted in competition between mycorrhizal fungi and saprotrophic microorganisms for litterderived resources, with mycorrhizal fungi suppressing the activity of saprotrophic microorganisms. 
Variations between the altitudes suggest that at the studied tropical montane forest ecosystems seasonality plays a larger role in structuring belowground communities than previously assumed. Oribatida appear to strongly depend on root-derived resources, while Collembola presumably benefitted from reduced competition between mycorrhizal fungi and saprotrophic microorganisms.

\section{References}

Anichkin AE, Belyaeva N V., Dovgobrod IG, Shveenkova YB, Tiunov A V. 2007. Soil microarthropods and macrofauna in monsoon tropical forests of Cat Tien and Bi Dup-Nui Ba National Parks, Southern Vietnam. Biology Bulletin 34: 498-506.

Averill C, Turner BL, Finzi AC. 2014. Mycorrhiza-mediated competition between plants and decomposers drives soil carbon storage. Nature 505: 543-545.

Bais HP, Weir TL, Perry LG, Gilroy S, Vivanco JM. 2006. The role of root exudates in rhizosphere interactions with plants and other organisms. Annual Review of Plant Biology 57: 233-266.

Bardgett RD. 2005. The Biology of Soil: A community and ecosystem approach. Oxford: Oxford University Press.

Barthlott W, Mutke J, Rafiqpoor D, Kier G, Kreft H. 2005. Global centers of vascular plant diversity. Nova Acta Leopoldina 92: 61-83.

Bending GD. 2003. Litter decomposition, ectomycorrhizal roots and the 'Gadgil' effect. New Phytologist 158: 227-238.

Berg B. 2014. Decomposition patterns for foliar litter - A theory for influencing factors. Soil Biology and Biochemistry 78: 222-232.

Berg B, McClaugherty C. 2008. Plant Litter: Decomposition, Humus Formation, Carbon Sequestration. Berlin, Heidelberg: Springer Verlag.

Bertin C, Yang X, Weston LA. 2003. The role of root exudates and allelochemicals in the rhizosphere. Plant and Soil 256: 67-83.

Brehm G, Fiedler K, Häuser CL, Dalitz H. 2008. Methodical Challenges of a Megadiverse Ecosystem. In: Beck E, ed. Gradients in a Tropical Mountain Ecosystem of Ecuador. Ecological Studies. Heidelberg: Springer-Verlag Berlin, 41-47.

Bruijnzeel LA, Hamilton LS. 2000. Decision time for cloud forests. IHP humid tropics programme.

Cesarz S, Fender A-C, Beyer F, Valtanen K, Pfeiffer B, Gansert D, Hertel D, Polle A, Daniel R, Leuschner C, et al. 2013. Roots from beech (Fagus sylvatica L.) and ash (Fraxinus excelsior L.) differentially affect soil microorganisms and carbon dynamics. Soil Biology and Biochemistry 61: 23-32.

Chahartaghi M, Langel R, Scheu S, Ruess L. 2005. Feeding guilds in Collembola based on nitrogen stable isotope ratios. Soil Biology and Biochemistry 37: 1718-1725.

Coleman DC. 1994. The microbial loop concept as used in terrestrial soil ecological studies. Microbial ecology 28: 245-250.

Coûteaux M-M, Bottner P, Berg B. 1995. Litter decomposition, climate and litter quality. Trends in Ecology and Evolution 10: 63-66.

Coûteaux M-M, Sarmiento L, Bottner P, Acevedo D, Thiéry JM. 2002. Decomposition of standard plant material along an altitudinal transect $(65-3968 \mathrm{~m})$ in the tropical Andes. Soil Biology and Biochemistry 34: 69-78. 
Cox PM, Pearson D, Booth BB, Friedlingstein P, Huntingford C, Jones CD, Luke CM. 2013. Sensitivity of tropical carbon to climate change constrained by carbon dioxide variability. Nature 494: 341-344.

Davidson EA, Janssens IA. 2006. Temperature sensitivity of soil carbon decomposition and feedbacks to climate change. Nature 440: 165-173.

Dennis PG, Miller AJ, Hirsch PR. 2010. Are root exudates more important than other sources of rhizodeposits in structuring rhizosphere bacterial communities? FEMS Microbiology Ecology 72: 313-327.

Eissfeller V, Beyer F, Valtanen K, Hertel D, Maraun M, Polle A, Scheu S. 2013. Incorporation of plant carbon and microbial nitrogen into the rhizosphere food web of beech and ash. Soil Biology and Biochemistry 62: 76-81.

Erdmann G, Otte V, Langel R, Scheu S, Maraun M. 2007. The trophic structure of bark-living oribatid mite communities analysed with stable isotopes $(15 \mathrm{~N}, 13 \mathrm{C})$ indicates strong niche differentiation. Experimental and Applied Acarology 41: 1-10.

Ermilov SG, Sandmann D, Marian F, Maraun M. 2013a. New oribatid mites of the genera Machadobelba and Campachipteria Acari: Oribatida) from Ecuador. Systematic \& Applied Acarology 18: 145-152.

Ermilov SG, Sandmann D, Marian F, Maraun M. 2013b. New taxa and new records of oribatid mites of the family Galumnidae (Acari: Oribatida) from Ecuador. Zootaxa 3700: 259-270.

Ermilov SG, Sandmann D, Marian F, Maraun M. 2013c. Two new species of oribatid mites of the genus Truncozetes (Acari, Oribatida, Epactozetidae) from Ecuador. ZooKeys 31: 23-31.

Ettema CH, Wardle DA. 2002. Spatial soil ecology. Trends in Ecology and Evolution 17: 177-183.

Farrar J, Hawes M, Jones D, Lindow S. 2003. How roots control the flux of carbon to the rhizosphere. Ecology 84: 827-837.

Fischer BM, Schatz H, Maraun M. 2010. Community structure, trophic position and reproductive mode of soil and bark-living oribatid mites in an alpine grassland ecosystem. Experimental and Applied Acarology 52: 221-237.

Fisher JB, Malhi Y, Torres IC, Metcalfe DB, van de Weg MJ, Meir P, Silva-Espejo JE, Huasco WH. 2013. Nutrient limitation in rainforests and cloud forests along a 3,000-m elevation gradient in the Peruvian Andes. Oecologia 172: 889-902.

Franklin E, Hayek T, Fagundes EP, Silva LL. 2004. Oribatid mite (Acari: Oribatida) contribution to decomposition dynamic of leaf litter in primary forest, second growth, and polyculture in the Central Amazon. Brazilian journal of biology 64: 59-72.

Gadgil RL, Gadgil PD. 1971. Mycorrhiza and litter decomposition. Nature 233: 133.

Ghazoul J, Sheil D. 2010. Tropical rain forest ecology, diversity, and conservation. New York: Oxford University Press.

Gorham E. 1991. Northern peatlands: Role in the carbon cycle and probable responses to climatic warming. Ecological Applications 1: 182-195.

Graefe S, Hertel D, Leuschner C. 2008. Fine root dynamics along a 2,000 m elevation transect in South Ecuadorian mountain rainforests. Plant and Soil 313: 155-166.

Gregory PJ. 2006. Roots, rhizosphere and soil: the route to a better understanding of soil science? European Journal of Soil Science 57: 2-12.

Heethoff M, Koerner L, Norton RA, Raspotnig G. 2011. Tasty but protected-First evidence of chemical defense in Oribatid mites. Journal of Chemical Ecology 37: 1037-1043. 
Heethoff M, Raspotnig G. 2012. Expanding the 'enemy-free space' for oribatid mites: Evidence for chemical defense of juvenile Archegozetes longisetosus against the rove beetle Stenus juno. Experimental and Applied Acarology 56: 93-97.

Henderson A, Churchill SP, Luteyn JL. 1991. Neotropical plant diversity. Nature 351: 21-22.

Heneghan L, Coleman DC, Zou X, Crossley DA, Haines BL. 1999. Soil microarthropod contributions to decomposition dynamics: Tropical-temperate comparisons of a single substrate. Ecology 80: 1873-1882.

Hiltner L. 1904. Über neuere Erfahrungen und Probleme auf dem Gebiete der Bodenbakteriologie unter besonderer Berücksichtigung der Gründüngung und Brache. Arbeiten der Deutschen Landwirtschaftlichen Gesellschaft 98: 59-78.

Hodge A, Campbell CD, Fitter AH. 2001. An arbuscular mycorrhizal fungus accelerates decomposition and acquires nitrogen directly from organic material. Nature 413: 297-299.

Hodge A, Fitter AH. 2010. Substantial nitrogen acquisition by arbuscular mycorrhizal fungi from organic material has implications for $\mathrm{N}$ cycling. Proceedings of the National Academy of Sciences of the United States of America 107: 13754-13759.

Hodge A, Robinson D, Fitter A. 2000. Are microorganisms more effective than plants at competing for nitrogen? Trends in Plant Science 5: 304-308.

Homeier J, Dalitz H, Breckle S-W. 2002. Waldstruktur und Baumdiversität im montanen Regenwald der Estación Cientifíca San Francisco in Südecuador. Bericht der Reinhessischen TüxenGesellschaft 14: 109-118.

Illig J, Langel R, Norton RA, Scheu S, Maraun M. 2005. Where are the decomposers? Uncovering the soil food web of a tropical montane rain forest in southern Ecuador using stable isotopes (15N). Journal of Tropical Ecology 21: 589-593.

Illig J, Norton RA, Scheu S, Maraun M. 2010. Density and community structure of soil- and barkdwelling microarthropods along an altitudinal gradient in a tropical montane rainforest. Experimental and Applied Acarology 52: 49-62.

Illig J, Schatz H, Scheu S, Maraun M. 2008. Decomposition and colonization by micro-arthropods of two litter types in a tropical montane rain forest in southern Ecuador. Journal of Tropical Ecology 24: 157-167.

Johnson NC, Rowland DL, Corkidi L, Egerton-Warburton LM, Allen EB. 2003. Nitrogen enrichment alters mycorrhizal allocation at five mesic to semiarid grasslands. Ecology 84: 1895-1908.

Kirschbaum MUF. 1995. The temperature dependence of soil organic matter decomposition, and the effect of global warming on soil organic $C$ storage. Soil Biology and Biochemistry 27: 753-760.

Koller R, Scheu S, Bonkowski M, Robin C. 2013. Protozoa stimulate $N$ uptake and growth of arbuscular mycorrhizal plants. Soil Biology and Biochemistry 65: 204-210.

Krantz GW, Behan-Pelletier V, Cook DR, Harvey MS, Keirans JE, Lidquist EE, Norton R a., OConnor BM, Smith IM, Walter D. 2009. A Manual of Acarology (GW Krantz and DE Walter, Eds.). Texas Tech University Press.

Leifheit EF, Verbruggen E, Rillig MC. 2015. Arbuscular mycorrhizal fungi reduce decomposition of woody plant litter while increasing soil aggregation. Soil Biology and Biochemistry 81: 323328.

Leigh J, Fitter AH, Hodge A. 2011. Growth and symbiotic effectiveness of an arbuscular mycorrhizal fungus in organic matter in competition with soil bacteria. FEMS microbiology ecology 76: 428-438. 
Leuschner C, Moser G, Bertsch C, Röderstein M, Hertel D. 2007. Large altitudinal increase in tree root/shoot ratio in tropical mountain forests of Ecuador. Basic and Applied Ecology 8: 219230.

Maraun M, Fronczek S, Marian F, Sandmann D, Scheu S. 2013. More sex at higher altitudes: Changes in the frequency of parthenogenesis in oribatid mites in tropical montane rain forests. Pedobiologia 56: 185-190.

Maraun M, Salamon JA, Schneider K, Schaefer M, Scheu S. 2003. Oribatid mite and collembolan diversity, density and community structure in a moder beech forest (Fagus sylvatica): Effects of mechanical perturbations. Soil Biology and Biochemistry 35: 1387-1394.

Maraun M, Schatz H, Scheu S. 2007. Awesome or ordinary? Global diversity patterns of oribatid mites. Ecography 30: 209-216.

Maraun M, Scheu S. 2000. The structure of oribatid mite communities (Acari, Oribatida): patterns, mechanisms and implications for future research. Ecography 23: 374-383.

Maraun M, Visser S, Scheu S. 1998. Oribatid mites enhance the recovery of the microbial community after a strong disturbance. Applied Soil Ecology 9: 175-181.

McNaughton SJ, Oesterheld M, Frank DA, Williams KJ. 1989. Ecosystem-level patterns of primary productivity and herbivory in teresstrial habitats. Nature 341: 142-144.

Moore JC, Walter DE, Hunt HW. 1988. Arthropod regulation of micro- and mesobiota in belowground detrital food webs. Annual Review of Entomology 33: 419-439.

Moser G, Hertel D, Leuschner C. 2007. Altitudinal change in LAI and stand leaf biomass in tropical montane forests: a transect study in Ecuador and a pan-tropical meta-analysis. Ecosystems 10: 924-935.

Mosse B. 1973. Advances in the study of vesicular-arbuscular mycorrhiza. Annual Review of Phytopathology 11: 171-196.

Myers N, Mittermeier RA, Mittermeier CG, da Fonseca GAB, Kent J. 2000. Biodiversity hotspots for conservation priorities. Nature 403: 853-858.

Ngosong C, Gabriel E, Ruess L. 2014. Collembola grazing on arbuscular mycorrhiza fungi modulates nutrient allocation in plants. Pedobiologia 57: 171-179.

Norton RA, Bonamo PM, Grierson JD, Shear WA. 1988. Oribatid mite fossils from a terrestrial Devonian deposit near Gilboa, New York. Journal of Paleontology 62: 259-269.

Nuccio EE, Hodge A, Pett-Ridge J, Herman DJ, Weber PK, Firestone MK. 2013. An arbuscular mycorrhizal fungus significantly modifies the soil bacterial community and nitrogen cycling during litter decomposition. Environmental Microbiology 15: 1870-1881.

Olsson PA, Chalot M, Baath E, Finlay RD, Söderstöm B. 1996. Ectomycorrhizal mycelia reduce bacterial activity in a sandy soil. FEMS microbiology ecology 21: 77-86.

Peschel K, Norton RA, Scheu S, Maraun M. 2006. Do oribatid mites live in enemy-free space? Evidence from feeding experiments with the predatory mite Pergamasus septentrionalis. Soil Biology and Biochemistry 38: 2985-2989.

Pitman NCA, Jørgensen PM. 2002. Estimating the size of the world's threatened flora. Science (New York, N.Y.) 298: 989.

Pollierer MM, Dyckmans J, Scheu S, Haubert D. 2012. Carbon flux through fungi and bacteria into the forest soil animal food web as indicated by compound-specific $13 \mathrm{C}$ fatty acid analysis (K Treseder, Ed.). Functional Ecology 26: 978-990.

Pollierer MM, Langel R, Körner C, Maraun M, Scheu S. 2007. The underestimated importance of belowground carbon input for forest soil animal food webs. Ecology letters 10: 729-736. 
Post WM, Emanuel WR, Zinke PJ, Stangenberger AG. 1982. Soil carbon pools and world life zones. Nature 298: 156-159.

Richardson BA, Richardson MJ, Soto-Adames FN. 2005. Separating the effects of forest type and elevation on the diversity of litter invertebrate communities in a humid tropical forest in Puerto Rico. Journal of Animal Ecology 74: 926-936.

Sanders NJ, Dunn RR, Fitzpatrick MCF, Carlton CE, Pogue MR, Parker CR, Simons TR. 2009. Diverse elevational diversity gradients in Great Smoky Mountains National Park, USA. In: Spehn EM,, In: Körner C, eds. Data Mining for Global Trends inMountain Biodiversity. Boca Raton, FL:CRC Press, 75-88.

Schaefer I, Norton RA, Scheu S, Maraun M. 2010. Arthropod colonization of land - Linking molecules and fossils in oribatid mites (Acari, Oribatida). Molecular Phylogenetics and Evolution 57: 113-121.

Scheu S. 2002. The soil food web: structure and perspectives. European Journal of Soil Biology 38: $11-20$.

Schneider K, Maraun M. 2009. Top-down control of soil microarthropods - Evidence from a laboratory experiment. Soil Biology and Biochemistry 41: 170-175.

Schneider K, Migge S, Norton RA, Scheu S, Langel R, Reineking A, Maraun M. 2004a. Trophic niche differentiation in soil microarthropods (Oribatida, Acari): evidence from stable isotope ratios (15N/14N). Soil Biology and Biochemistry 36: 1769-1774.

Schneider K, Renker C, Scheu S, Maraun M. 2004b. Feeding biology of oribatid mites: a minireview. Phytophaga 14: 247-256.

Shear WA, Bonamo PM, Grierson JD, Rolfe WDI, Smith EL, Norton RA. 1984. Early Land Animals in North America: Evidence from Devonian Age Arthropods from Gilboa, New York. Science 224: 492-494.

Smith SE, Read D. 2008. Mycorrhizal Symbiosis. Amsterdam, Boston: Academic Press.

Subias LS. 2015. Listado sistemático, sinonímico y biogeográfico de los ácaros oribátidos (Acariformes: Oribatida) del mundo (excepto fósiles),. http://www.ucm.es/info/zoo/Artropodos/Catalogo.pdf/: 564.

Sundqvist MK, Sanders NJ, Wardle D a. 2013. Community and ecosystem responses to elevational gradients: Processes, mechanisms, and insights for global change. Annual Review of Ecology, Evolution, and Systematics 44: 261-280.

Todd-Brown KEO, Randerson JT, Hopkins F, Arora V, Hajima T, Jones C, Shevliakova E, Tjiputra J, Volodin E, Wu T, et al. 2014. Changes in soil organic carbon storage predicted by Earth system models during the 21st century. Biogeosciences 11: 2341-2356.

Walter DE, Proctor HC. 2013. Mites: Ecology, evolution \& behaviour: Life at a microscale. New York, London: Springer International Publishing.

Wardle DA, Yeates GW, Barker GM, Bonner KI. 2006. The influence of plant litter diversity on decomposer abundance and diversity. Soil Biology and Biochemistry 38: 1052-1062.

Whipps JM, Lynch JM. 1983. Substrate flow and utilization in the rhizosphere of cereals. New Phytologist 95: 605-623.

Whitmore TC. 1990. An introduction to tropical rain forests. Oxford: Oxford University Press.

Willig MR, Presley SJ. 2015. Biodiversity and metacommunity structure of animals along altitudinal gradients in tropical montane forests. Journal of Tropical Ecology: 1-16.

Zieger SL, Eissfeller V, Maraun M, Scheu S. 2015. Incorporation of carbon and nitrogen from leaf litter differing in structural compounds into soil microarthropods of a deciduous forest. Pedobiologia 58: 219-227. 


\section{Chapter 2}

Decomposition of leaf and root litter in tropical montane rainforests suggests strong nutrient limitation resulting in long-term carbon sequestration
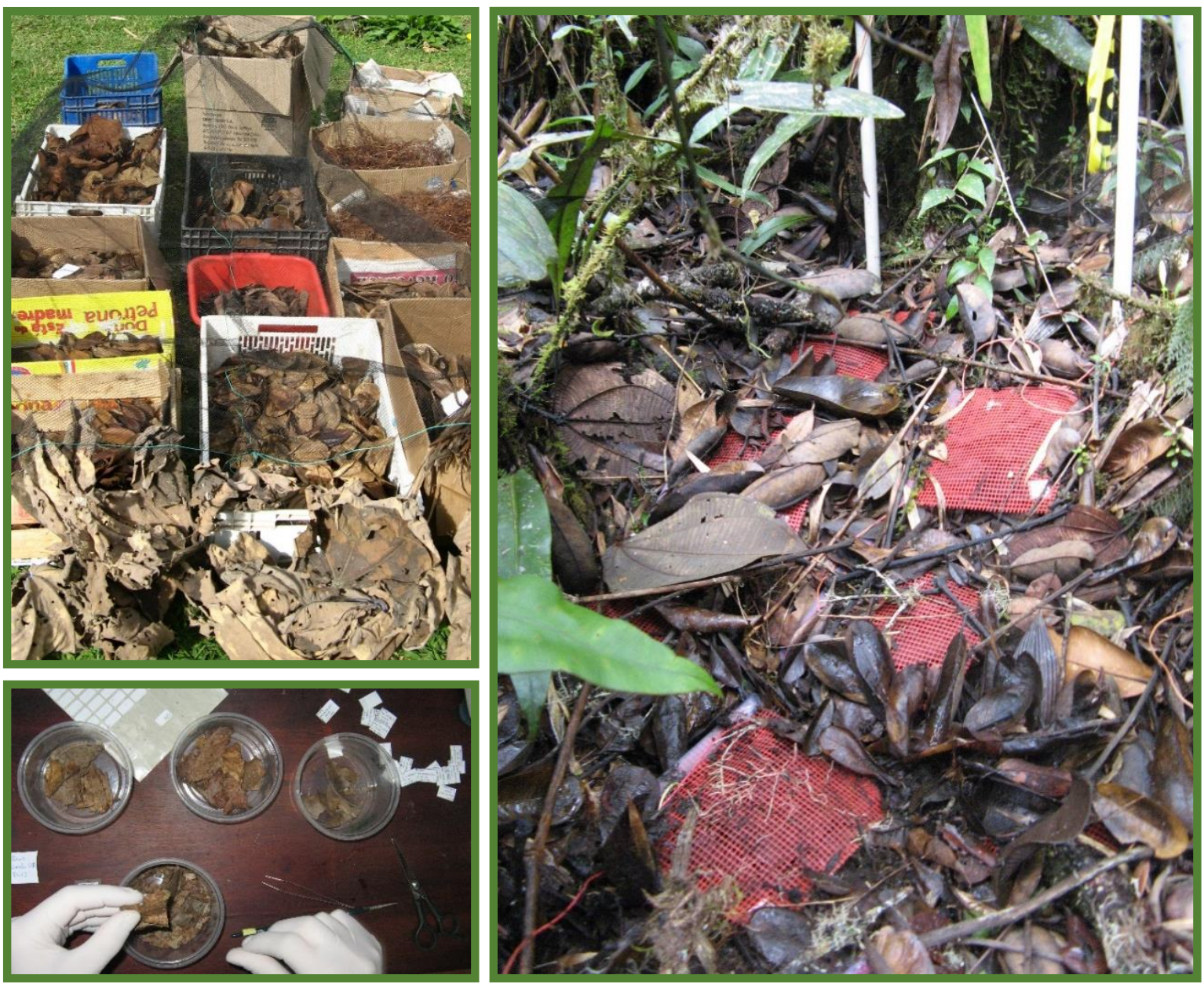

Franca Marian, Dorothee Sandmann, Valentyna Krashevska, Mark Maraun and Stefan Scheu 


\begin{abstract}
Decomposition is among the most fundamental processes in terrestrial ecosystems. Especially in tropical montane rainforests, which harbour large stocks of dead organic material, little is known about the factors driving decomposition processes. We investigated the effect of altitude, litter origin and litter type on long term decomposition rates and microorganisms in a tropical montane rainforest in southern Ecuador. Leaf litter from three abundant tree species and roots of different diameter were collected from three sites along an altitudinal gradient (1000, 2000, $3000 \mathrm{~m})$. Litter and roots were placed in litterbags at the three altitudes, and after 6, 12, 24, 36 and 48 months the remaining amount and percentage of $\mathrm{C}$ and $\mathrm{N}$ as well as microbial biomass and the metabolic oxygen quotient were determined.
\end{abstract}

Altitude and time were the main factors driving litter decomposition, while origin and therefore quality of the litter material was of minor importance. At 2000 and $3000 \mathrm{~m}$ the amount of $C$ declined over the first 12 months, before reaching a limit value of $~ 50 \%$ of initial not decomposing further from 12 to 24 months; only after 36 months decomposition commenced but at very low rates resulting in an average of $37.9 \%$ and $44.4 \%$ of initial remaining after 48 months, at 2000 and $3000 \mathrm{~m}$, respectively. In contrast, at $1000 \mathrm{~m}$ decomposition was more continuous resulting in only $10.9 \%$ of litter remaining after 48 months. This suggests that after 12 months lignified litter components accumulate at higher altitudes contributing to the formation of thick layers of dead organic material. In contrast, at $1000 \mathrm{~m}$ favourable conditions for litter decomposition prevent the accumulation of soil organic matter. Changes in decomposition rates in time especially after 24 months were paralleled by changes in microbial parameters but these varied with site specific conditions. At higher altitudes microbial biomass decreased after 24 months indicating a shift in the microbial community, while at $1000 \mathrm{~m}$ microbial biomass remained rather constant.

The results suggest that factors associated with thick layers of organic material at high altitudes inhibit decomposition processes, presumably low supply of nutrients, in particular $\mathrm{N}$, causing the microbial community to largely depend on root-derived resources and decomposition processes to be exceptionally slow, indicating close linkage between plant roots and litter decomposition processes. 


\section{Introduction}

Decomposition is among the most fundamental processes in terrestrial ecosystems, with over $90 \%$ of the aboveground net primary production entering the decomposer food web as leaf and root litter (McNaughton et al., 1989). Regulatory forces of decomposition processes attract increasing attention in the current debate on the functioning of ecosystems as sinks or sources for carbon (C) (Cox et al., 2013; Todd-Brown et al., 2014). Extensive amounts of C are stored in dead organic matter, with peatlands, tundra and the boreal zone containing an estimated one-third of the global C stock (Post et al., 1982; Gorham, 1991). A release of this $C$ in either gaseous or aqueous form may contribute substantially to the increasing $\mathrm{CO}_{2}$ concentrations in the atmosphere (Cox et al., 2013). Current models projecting the response of soil organic $C$ pools to climate change and elevated atmospheric $\mathrm{CO}_{2}$ levels are still uncertain whether $\mathrm{C}$ storage will increase or decline and more data on regulatory forces of decomposition processes are needed (Cox et al., 2013; Todd-Brown et al., 2014). Litter quality, climate and the decomposer community are the main factors controlling decomposition rates (Kirschbaum, 1995; Coûteaux et al., 2002; Davidson \& Janssens, 2006; Berg, 2014). Litter quality is known to regulate decomposition processes mainly in the early stages of decomposition, while climatic conditions become more important with time (Berg \& McClaugherty, 2008). Sensitivity of decomposition processes to changes in temperature have widely been studied, however, with controversial outcomes (Kirschbaum, 1995; Giardina \& Ryan, 2000; Fang et al., 2005; Fierer et al., 2005; Knorr et al., 2005; Davidson \& Janssens, 2006). Fang et al. (2005) and Giardina et al. (2000) found the decomposition of soil organic matter not to be affected by temperature, while Fierer et al. (2009) stated that the influence of temperature on litter decomposition depends on the quality of the litter material. Effects of both litter quality and temperature on litter decomposition are largely mediated through their effects on the microbial community (Allison et al., 2010; Treseder et al., 2012; Cleveland et al., 2014), which is known to be affected by changes in temperature (Allison \& Treseder, 2008; Frey et al., 2013) and litter quality (Cleveland et al., 2014). Large stocks of dead organic material are not only stored in peatlands of the boreal zone but also in tropical regions (Post et al., 1982; Pan et al., 2011). Generally, decomposition processes in the humid tropics are faster compared to temperate regions (Heneghan et al., 1999). However, in cold tropical montane rainforests at high altitude litter decomposition is slow compared to lowland tropical rainforests causing soil organic $C$ to accumulate (Post et al., 1982; Heneghan et al., 1999; Dieleman et al., 2013; Butenschoen et al., 2014). In the tropical Andes, one of the most species rich and diverse ecosystems on earth (Henderson et al., 1991; Barthlott et al., 2005; Hilt \& Fiedler, 2005), montane rainforests are exposed to strong variations in biotic and abiotic conditions on small spatial scales (Homeier et al., 2010). Studies in the area of the Reserva Biológica San Francisco in the southern Ecuadorian Andes showed litter decomposition to vary markedly along an altitudinal 
gradient spanning about $2000 \mathrm{~m}$ (Illig et al., 2008). With increasing altitude, litter decomposition slows down and soil organic matter as well as soil C stocks increase (Wilcke et al., 2002; Leuschner et al., 2007; Illig et al., 2008). These altitudinal variations are associated with changes in plant community composition (Paulsch et al., 2006; Moser et al., 2007; Wilcke et al., 2008; Homeier et al., 2010) and declining quality of leaf litter material with increasing altitude, resulting in the formation of soil organic matter layers of low quality at higher altitude (Wilcke et al., 2002). Further, aboveground standing biomass and tree diversity decrease with increasing altitude (Giardina \& Ryan, 2000; Homeier et al., 2010), which is especially relevant since plant species diversity is known as driver for decomposition processes (Butenschoen et al., 2014). The biomass of living and dead fine roots as well as living coarse roots increases significantly with increasing altitude (Leuschner et al., 2007; Girardin et al., 2010). Therefore, fine root necromass is an important factor contributing to the formation of thick organic layers at high altitudes of tropical montane forest ecosystems. In addition to changes in plant community composition, also the plant associated mycorrhiza community changes with altitude in tropical montane forest ecosystems (Kottke \& Haug, 2004; Kottke et al., 2006). Generally, in tropical montane ecosystems the mycorrhizal community is dominated by arbuscular mycorrhizal fungi (AMF) (Kottke et al., 2004), which are known to be closely linked to the microbial and protozoan community (Bonkowski \& Clarholm, 2012; Koller et al., 2013b). Mycorrhizal fungi communities recently also have been suggested to directly and indirectly influence decomposition processes and soil organic C stocks (Averill et al., 2014). Temperature and precipitation also change with altitude (Röderstein et al., 2005; Moser et al., 2007), and Wilcke et al. (2002) suggested low temperatures, increased precipitation and waterlogging to be responsible for the accumulation of dead organic material in high altitude Andean forest ecosystems. Contrasting this view, Krashevska et al. (2012) reported microbial biomass to decrease with declining precipitation and Illig et al. (2008) found temperature to only be of minor importance for decomposition processes in montane Andean forest ecosystems. This suggests that other factors than moisture and temperature are crucial in regulating decomposition rates in tropical montane forest ecosystems.

In this study we investigated the influence of altitude, i.e. site specific conditions, and litter origin, i.e. litter quality, on decomposition of leaf and root litter in the Andean tropical montane rainforest of southern Ecuador. The study aims at improving the understanding of the mechanisms contributing to the accumulation of dead organic material at high altitude sites. We measured $\mathrm{C}$ and nitrogen $(\mathrm{N})$ as well as microbial biomass concentrations in a litterbag experiment including both leaf and root litter over the course of four years. In detail the study aims to disentangle (1) whether decomposition rates as well as changes in $\mathrm{C}$ and $\mathrm{N}$ concentrations in decomposing litter material are driven by the quality of the litter material, i.e. the origin of litter from rainforests of 
different altitude, or biotic and abiotic site specific conditions, and (2) whether leaf and root litter decomposition rates are driven by similar factors. We further investigated (3) variations in microbial biomass and ergosterol concentrations during decomposition to link changes in litter biota to litter decomposition processes.

\section{Material and methods}

\section{Study site}

The study area, with three study sites along an altitudinal gradient at 1000, 2000 and $3000 \mathrm{~m}$ a.s.l., is located in southern Ecuador on the eastern slope of the Andes. The study sites are in the northern part of the Podocarpus National Park facing northeast to northwest. The slopes are moderately steep with $26^{\circ}-31^{\circ}$ (Moser et al., 2007) and covered with mostly undisturbed montane rainforest (Homeier et al., 2002). The site at $1000 \mathrm{~m}$ (Bombuscaro, S04 $06^{\prime} 54^{\prime \prime}, \mathrm{W} 78^{\circ} 58^{\prime} 02^{\prime \prime}$ ) is located south of the city Zamora in the valley of the Rio Bombuscaro. The site at $2000 \mathrm{~m}$ (San Francisco, $\left.\mathrm{S} 3^{\circ} 58^{\prime} 18^{\prime \prime}, \mathrm{W} 79^{\circ} 4^{\prime} 45^{\prime \prime}\right)$ is part of a private reserve, the Reserva Biologica San Francisco, which includes an area of 9 ha on the flank of the valley of the Rio San Francisco on the northern border of the Podocarpus National Park. The site at 3000 m (Cajanuma, S04 $06^{\prime} 711^{\prime \prime}$, W79 $10^{\prime} 58^{\prime \prime}$ ) is located south of the city Loja at the north-west gate of the Podocarpus National Park.

With 8-10 humid months per year the region has a semi humid climate. Mean annual rainfall increases from 2230 and $1950 \mathrm{~mm}$ at 1000 and $2000 \mathrm{~m}$, respectively, to $4500 \mathrm{~mm}$ at $3000 \mathrm{~m}$ (Moser et al., 2007), while the mean annual air temperature gradually decreases with increasing altitude from 19.4 to 15.7 to $9.4^{\circ} \mathrm{C}$ at 1000,2000 and $3000 \mathrm{~m}$, respectively. Soil pH also gradually decreases with increasing altitude from 3.94 to 3.52 to 2.86 at 1000, 2000 and $3000 \mathrm{~m}$, respectively (Moser et al., 2007). With increasing altitude the mean soil moisture in the organic layer increases to 45.3 vol.\% at $3000 \mathrm{~m}$ as compared to 9.9 and 11.6 vol.\% at 1000 and $2000 \mathrm{~m}$, respectively (Leuschner et al., 2007). Biotic conditions also change along the altitudinal gradient. Mean tree height decreases from 15.6 to 10.1 to $5.2 \mathrm{~m}$ at 1000, 2000 and $3000 \mathrm{~m}$, respectively, while thickness of organic layers as well as fine root biomass increases from $48 \mathrm{~mm}$ and $2.7 \mathrm{t} \mathrm{ha}^{-1}$ to $305 \mathrm{~mm}$ and $6.2 \mathrm{t} \mathrm{ha}^{-1}$ to $435 \mathrm{~mm}$ and $10.8 \mathrm{t} \mathrm{ha}^{-1}$ at the respective sites (Moser et al., 2007; Graefe et al., 2008). Soil types at 1000, 2000 and 3000 m are predominantly Alumic Acrisols, Gley Cambisols and Podzols, respectively (Moser et al., 2007). At $1000 \mathrm{~m}$ the litter layer overlays the mineral soil (Ah horizon), i.e. $\mathrm{F}$ and $\mathrm{H}$ layers are lacking; in contrast, at 2000 and $3000 \mathrm{~m}$ the leaf litter overlays thick organic layers comprising predominantly of $\mathrm{F}$ material. 


\section{Experimental setup}

Nylon bags (litterbags, $4 \mathrm{~mm}$ mesh) were used to investigate the influence of altitude and litter origin on decomposition and microbial colonization of leaves and roots, i.e. two types of litter materials. At each of the three study sites freshly fallen leaves of the three most abundant tree families at the respective site with differing C-to-N ratios (See Appendix Table S1) were collected from the forest floor (origins; Bombuscaro $=$ Bomb, Estacion Cientifica San Francisco $=$ ECSF, Cajanuma $=$ Caja). Roots where collected by digging up the upper 20 to $30 \mathrm{~cm}$ of organic material and soil, and removing roots by hand. To clear from adhering organic matter and soil, roots where washed by gentle rinsing with tap water. Roots were separated into three size classes, small ( $<2 \mathrm{~mm}$ diameter), medium ( $2-5 \mathrm{~mm}$ diameter) and large ( $>5 \mathrm{~mm}$ diameter). Both leaf litter and roots where dried at $60^{\circ} \mathrm{C}$ for four days.

To simulate natural conditions and at the same time standardize conditions as far as possible, litterbags were filled with $10 \mathrm{~g}$ of leaf or root litter by mixing leaves of the three plant families, respectively root size classes, according to the relative abundance of leaf families/root size classes at the three altitudes (Table 1).

Table 1: Leaf litter species and root litter size groups placed into the litterbags and the amount of each used (g dry weight) from the three study sites Bombuscaro (Bomb, $1000 \mathrm{~m}$ ), Estacion Cientifica San Francisco (ECSF, $2000 \mathrm{~m}$ ) and Cajanuma (Caja, $3000 \mathrm{~m}$ ). The amount of litter placed into litterbags of the three litter species respectively root size classes was based on the amount present at the respective study site.

\begin{tabular}{lcll}
\hline Leaves & \multicolumn{2}{l}{ Roots } \\
\hline Bomb & [g] & Bomb & [g] \\
\hline Pouteria sp. & 5 & small & 2.8 \\
Cavendishia zamorensis & 3 & medium & 4.9 \\
Mollinedia sp. & 2 & large & 2.5 \\
\hline ECSF & & ECSF & \\
\hline Graffenrieda emarginata & 5 & small & 4.4 \\
Clusia spp. & 4 & medium & 2.1 \\
Cavendishia zamorensis & 1 & large & 3.5 \\
\hline Caja & & Caja & \\
\hline Clusia spp. & 5 & small & 3.4 \\
Graffenrieda emarginata & 4 & medium & 2.5 \\
Hedyosmum sp. & 1 & large & 4.1 \\
\hline
\end{tabular}

Litterbags filled with the six different litter mixtures ( 3 origins $\times 2$ types), where placed at the study sites on each of the three altitudes (Fig. 1). Leaf litterbags were placed on top of the litter layer, whereas root litterbags were placed in between the soil $(1000 \mathrm{~m})$, respectively F layer (2000 and $3000 \mathrm{~m}$ ) and the fresh litter layer, where fine root density is at a maximum (Röderstein et al., 2005). At each of the three study sites four blocks were established, minimum distance between the blocks was $20 \mathrm{~m}$. In each block five replicates of each treatment were placed with one replicate from each 
block being retrieved at each of five dates, i.e. after $6,12,24,36$ and 48 months, resulting in 360 litterbags in total.

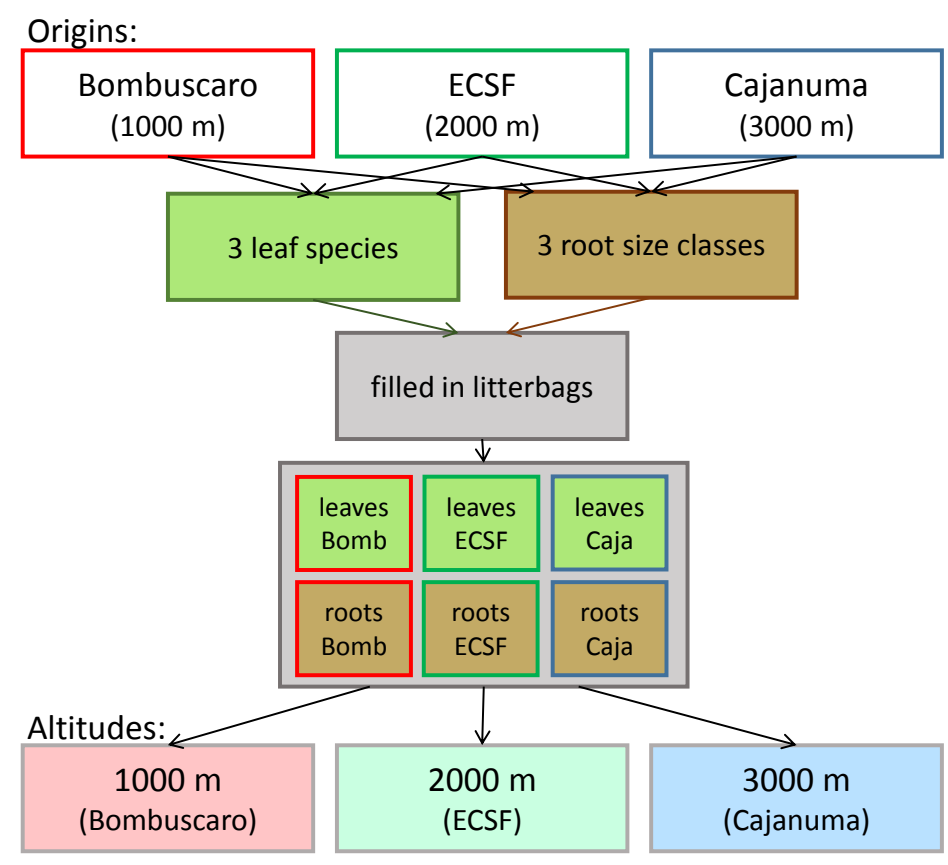

Fig. 1: Scheme of collection of litter materials (origins) and placement of litterbags (altitudes). Leaf and root litter samples from three sites (origins: Bombuscaro (Bomb, $1000 \mathrm{~m}$ ), Estacion Cientifica San Francisco (ECSF, $2000 \mathrm{~m}$ ) and Cajanuma (Caja, $3000 \mathrm{~m}$ )) were placed in litterbags; six litterbags, three with leaves and three with roots, were set up per site and placed in the field at each of the respective sites where leaf litter and roots were sampled.

\section{Analytical procedures}

After retrieval the remaining leaf and root litter was stored at $4^{\circ} \mathrm{C}$ and transported to Germany, where it was cleaned by removing soil, plants and roots grown into the litterbags, and then dried at $60^{\circ} \mathrm{C}$ for four days. Litter dry mass was measured gravimetrically. For measuring $\mathrm{C}$ and $\mathrm{N}$ concentrations an aliquot of the litter material was milled to powder and 3-4 mg from each sample were filled into tin capsules and analysed using an elemental analyser (Vario EL III, elementar, Hanau, Germany).

Microbial respiration and substrate-induced respiration (SIR) were determined by measuring $\mathrm{O}_{2}$ consumption using a computer controlled $\mathrm{O}_{2}$ microcompensation apparatus (Scheu, 1992). Material from each litterbag was cut into pieces of about $0.5 \mathrm{~cm}^{2}$, water content was adjusted to about $60 \%$ of the water holding capacity and the samples were rested for 4 days at room temperature. Then, $\mathrm{O}_{2}$ consumption was measured for $24 \mathrm{~h}$. Microbial biomass was determined by measuring SIR (Anderson \& Domsch, 1978). Moist samples equivalent to $0.2 \mathrm{~g}$ dry weight were supplemented with glucose equivalent to $80 \mathrm{mg} \mathrm{g}^{-1} \mathrm{dry}$ weight and the measurement of the $\mathrm{O}_{2}$ consumption continued for $24 \mathrm{~h}$. Microbial biomass was calculated from the maximum initial respiratory response (MIRR; $\mu \mathrm{O} \mathrm{O}_{2} \mathrm{~g}^{-1}$ dry mass $\mathrm{h}^{-1}$ ) as $\mathrm{C}_{\text {mic }}=38 *$ MIRR (Beck et al., 1997; Joergensen \& Scheu, 1999). 
Ergosterol was extracted from $0.5 \mathrm{~g}$ of leaf or root material with $50 \mathrm{ml}$ ethanol in bay-coloured glass vial by oscillating shaking for $30 \mathrm{~min}$ ( $250 \mathrm{rev}$. $\mathrm{min}^{-1}$ on a rocker). Then, samples were centrifuged at $3500 \mathrm{~g}$ for $40 \mathrm{~min}$. The supernatant was split in two $20 \mathrm{ml}$ samples and evaporated. The dried extract was collected in $0.5 \mathrm{ml}$ methanol and filtered through a membrane of $0.45 \mu \mathrm{m}$. Determination of ergosterol was done by reverse-phase high performance liquid chromatography (HPCL) (Djajakirana et al., 1996). Ergosterol concentrations were only measured from the first three sampling dates $(6,12$ and 24 months) due to lack of material at later dates, resulting in a total of 216 samples.

\section{Calculations and statistical analysis}

We focused on the variation in the amount and concentration of $C$ within the litter material to closely link decomposition processes to energetic processes. Therefore, the amount of $\mathrm{C}$ remaining $\left(C_{R}\right)$ in the litterbags at the sampling dates $(n)$ were expressed as percentages of the initial amount of $C$ placed in the litterbags $\left(C_{0}\right)$. Similarly, changes in the amount of $N$ remaining $\left(N_{R}\right)$ were expressed as percentage of the initial amount of $\mathrm{N}$ placed in the litterbags $\left(\mathrm{N}_{0}\right)$, according to the following formula:

$C_{R}[\%]=\left(C_{n} / C_{0}\right) \times 100$ and $N_{R}[\%]=\left(N_{n} / N_{0}\right) \times 100$, with $C_{n}$ and $N_{n}$ the amount of $C$ and $N$ remaining at each sampling date $n$.

The concentrations of $\mathrm{C}\left(\mathrm{C}_{\mathrm{C}}\right)$ and $\mathrm{N}\left(\mathrm{N}_{\mathrm{C}}\right)$ in the litter were calculated as:

$C_{c}[\%]=\left(C_{n} / D W_{n}\right) \times 100$ and $N_{c}[\%]=\left(N_{n} / D W_{n}\right) \times 100$, with $D W_{n}$ the dry weight of litter remaining at sampling date $n$.

In addition, the litter C-to-N mass ratio was calculated, but since variations were similar to those in the $\mathrm{N}_{\mathrm{C}}$, we focused on $\mathrm{N}_{\mathrm{C}}$ and only display C-to-N ratio in the appendix (Appendix Table S2, Fig. S1).

Microbial activity and density were quantified using four parameters. Microbial biomass $\left(\mathrm{C}_{\text {mic }}: \mu \mathrm{g} \mathrm{C} \mathrm{g}{ }^{-1} \mathrm{DW}\right)$, metabolic oxygen quotient $\left(\mathrm{qO}_{2}: \mu \mathrm{O}_{2} \mathrm{mg}^{-1} \mathrm{C}_{\text {mic }} \mathrm{h}^{-1}\right)$, the ratio between microbial carbon and total soil carbon ( $\mathrm{C}_{\text {mic }}$-to- $\mathrm{C}_{\text {org }}$ ratio) and the ration between the ergosterol concentration and total soil C ( $\left.\mu \mathrm{g} \mathrm{g}^{-1} \mathrm{C}\right)$.

The remaining amount and concentration of $C$ and $N\left(C_{R}, N_{R}, C_{C}, N_{C}\right.$ and $C$-to- $N$ ratio $)$ and microbial parameters $\left(\mathrm{C}_{\text {mic }}, \mathrm{qO}_{2}, \mathrm{C}_{\text {mic }}\right.$-to- $\mathrm{C}_{\text {org }}$ ratio and ergosterol concentration) were analysed by repeated measures four-factor randomized complete block multivariate analysis of variance (MANOVA) with time $(6,12,24,36$ and 48 months) as repeated factor and block (1, 2, 3 and 4) being nested for altitude. Fixed factors were altitude (1000, 2000 and 3000 m a.s.l.), origin (Bomb, ECSF and Caja) and litter type (leaf and root litter). Block was excluded from the analysis as there were no 
significant block effects. Protected repeated measures analysis of variance (ANOVA) with the same criteria as stated above were carried out with the general linear model (GLM; type III sum of squares), providing between and within subject effects and significant variations between the dates (Scheiner \& Gurevitch, 2001). Single ANOVAs for each sampling date were performed to identify differences between dates. Tukey's HSD test $(\alpha<0.05)$ was used to identify significant differences between means. Statistical analyses were performed using SAS (Statistical Analysis System, Version 9.3; SAS Institute Inc., Cary, NC, USA).

Further, all the measured parameters were correlated in a matrix in total and for each sampling date separately using STATISTICA 12 (Statsoft, Inc., Tulsa, USA) (Appendix Fig. S3 and S4). Before the analyses data were inspected for homogeneity of variance and normal distribution. Percentage data where arcsine square root- and all other date log-transformed. Means presented in the results are based on non-transformed data.

\section{Results}

Altitude had the strongest influence on $\mathrm{N}_{R}, \mathrm{C}_{\mathrm{C}}, \mathrm{qO}_{2}$ and $\mathrm{C}_{\text {mic }}$-to- $\mathrm{C}_{\text {org }}$ ratio. Litter type had the strongest influence on the ergosterol concentration, while $C_{R}$ and $C_{\text {mic }}$ varied strongest with sampling dates. The origin of litter material had the strongest influence on $\mathrm{N}_{c}$ (Table 2,3). The effect of origin of litter material on most of the investigated parameters was only significant at early sampling dates, affecting $C_{\text {mic }}$ and ergosterol concentration only after 6 months, $C_{\text {mic }}$-to- $C_{\text {org }}$ ratio after 6 and 24 months, $C_{c}$ after 12 and 36 months, while $C_{R}$ and $\mathrm{qO}_{2}$ were not affected by origin as main effect at any sampling date. Only $N_{R}$ and $N_{C}$ significantly varied with litter origin at each of the sampling dates. Results are therefore presented focusing on the effect of altitude, sampling date and litter type on the investigated parameters.

\section{Amount and concentration of $C$ and $N$}

$C_{R}$ declined with time but this varied significantly with altitude (Fig. 2a, Table 2). Within the first 6 months $C$ loss at all three altitudes was similar and averaged $15.8 \pm 2.6 \%$ of $C_{0}$. In contrast, from 6 to 12 months $C$ loss was highest at $1000 \mathrm{~m}$ (further $44.1 \%$ of $C_{0}$ ) but similar at 2000 and $3000 \mathrm{~m}$ (further 31.9 and $34.4 \%$ of $C_{0}$, respectively). From 12 to 36 months $C_{R}$ remained almost constant at 2000 and $3000 \mathrm{~m}$ at an average of $48.7 \pm 2.2$ and $54.5 \pm 3.2 \% C_{R}$, respectively. From 36 to 48 months $C_{R}$ again decreased by 8.2 and $8.5 \%$ of $C_{0}$ at 2000 and $3000 \mathrm{~m}$, respectively. In contrast, at $1000 \mathrm{~m}$ $C_{R}$ decreased steadily from 12 to 48 months by an average of $9.7 \pm 1.1 \%$ of $C_{0}$ each year resulting in only $10.9 \% C_{R}$ after 48 months. This contrasted 37.9 and $44.4 \% C_{R}$ after 48 months at 2000 and $3000 \mathrm{~m}$, respectively. 
Table 2: Repeated measures ANOVA/GLM table of F- and p-values on the effects of altitude (1000, 2000 and $3000 \mathrm{~m}$ ), litter type (roots or leaves), litter origin [Bombuscaro (Bomb), ECSF and Cajanuma (Caja)] and date $\left(6,12,24,36\right.$ and 48 months) on the amount of $C\left(C_{R}\right)$ and $N\left(N_{R}\right)$ in litterbags (as percentages of initial), the percentage of $C\left(C_{C}\right)$ and $N\left(N_{c}\right)$ in the litter and litter $C$-to- $N$ ratio. Significant effects are given in bold.

\begin{tabular}{|c|c|c|c|c|c|c|c|c|}
\hline & \multicolumn{2}{|c|}{$C_{R}$} & \multicolumn{2}{|c|}{$\mathrm{C}_{\mathrm{c}}$} & \multicolumn{2}{|c|}{$\mathrm{N}_{\mathrm{R}}$} & \multicolumn{2}{|c|}{$\mathrm{N}_{\mathrm{c}}$} \\
\hline & F-value & p-value & F-value & p-value & F-value & p-value & F-value & p-value \\
\hline \multicolumn{9}{|l|}{ Between subject effects } \\
\hline altitude & 219.26 & $<.0001$ & 111.59 & $<.0001$ & 103.48 & $<.0001$ & 45.66 & $<.0001$ \\
\hline origin & 1.18 & 0.3163 & 5.76 & 0.0057 & 35.81 & $<.0001$ & 337.75 & $<.0001$ \\
\hline type & 22.38 & $<.0001$ & 36.89 & $<.0001$ & 3.86 & 0.0552 & 128.82 & $<.0001$ \\
\hline altitude $\times$ origin & 1.64 & 0.1790 & 6.54 & 0.0003 & 2.52 & 0.0527 & 3.45 & 0.0147 \\
\hline altitude $\times$ type & 0.39 & 0.6819 & 47.53 & $<.0001$ & 3.67 & 0.0326 & 2.82 & 0.0696 \\
\hline origin $\times$ type & 7.91 & 0.0011 & 0.13 & 0.8761 & 7.00 & 0.0021 & 9.23 & 0.0004 \\
\hline altitude $\times$ origin $\times$ type & 2.59 & 0.0482 & 2.50 & 0.0548 & 3.02 & 0.0263 & 3.75 & 0.0098 \\
\hline \multicolumn{9}{|l|}{ Within subject effects } \\
\hline date & 271.93 & $<.0001$ & 58.88 & $<.0001$ & 78.99 & $<.0001$ & 136.79 & $<.0001$ \\
\hline date $\times$ altitude & 48.78 & $<.0001$ & 16.19 & $<.0001$ & 30.55 & $<.0001$ & 5.73 & $<.0001$ \\
\hline date $\times$ origin & 0.58 & 0.7933 & 2.63 & 0.0093 & 1.80 & 0.0791 & 6.02 & $<.0001$ \\
\hline date $\times$ type & 5.8 & 0.0002 & 1.00 & 0.4093 & 5.20 & 0.0005 & 3.96 & 0.0041 \\
\hline date $\times$ altitude $\times$ origin & 1.13 & 0.3322 & 1.52 & 0.0943 & 1.91 & 0.0216 & 2.68 & 0.0008 \\
\hline date $\times$ altitude $\times$ type & 0.44 & 0.8983 & 7.11 & $<.0001$ & 0.30 & 0.9665 & 4.70 & $<.0001$ \\
\hline date $\times$ origin $\times$ type & 1.43 & 0.1876 & 1.96 & 0.0541 & 2.62 & 0.0095 & 4.03 & 0.0002 \\
\hline date $\times$ altitude $\times$ origin $\times$ type & 0.61 & 0.8715 & 1.51 & 0.0994 & 0.51 & 0.9409 & 0.62 & 0.8633 \\
\hline
\end{tabular}

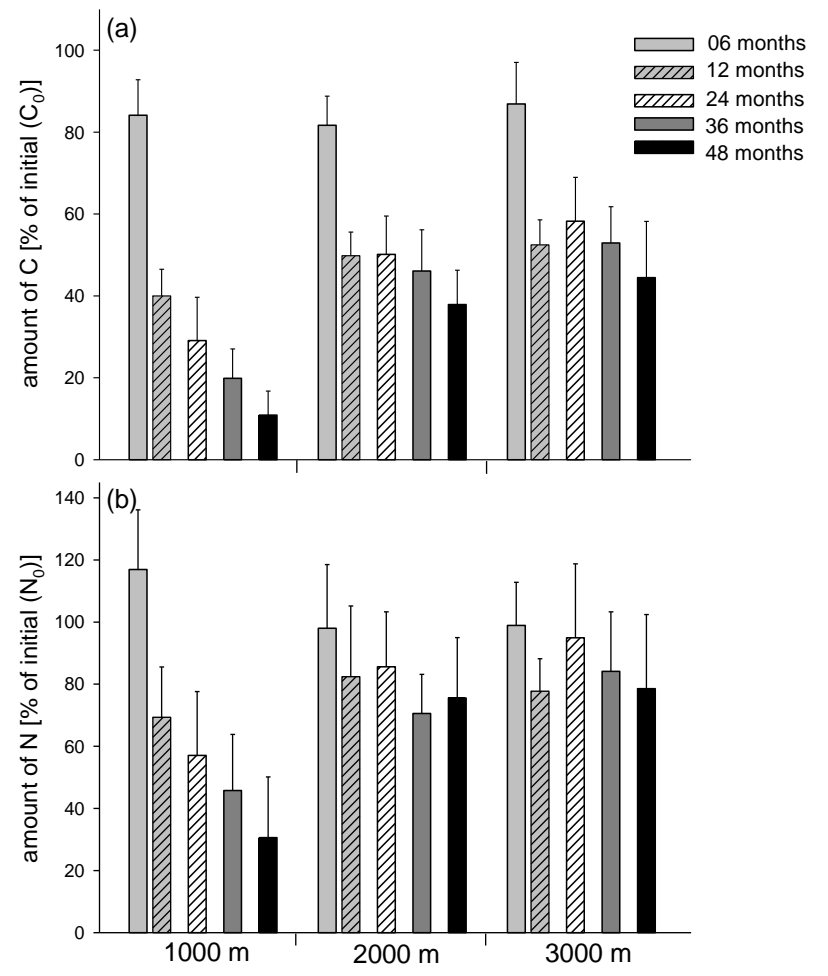

Fig. 2: Variation in the amount of $C\left(C_{R}\right)(a)$ and $N\left(N_{R}\right)(b)$ in litter (percentages of initial) exposed in tropical montane rainforests at three altitudes $(1000,2000$ and $3000 \mathrm{~m}$ ) for 6, 12, 24, 36 and 48 months (means \pm SD).

C loss also varied between root and leaf litter (interaction: date $\times$ type; Table 2). Within the first year the $C$ loss was similar in leaf and root litter, with an average of $15.8 \pm 0.5 \%$ of $C_{0}$ after 6 and an additional $36.9 \pm 1.6 \%$ of $C_{0}$ from 6 to 12 months. Between 12 and 24 months $C$ loss slightly differed 
between leaf and root litter, decreasing in leaf litter by $5.0 \%$ of $C_{0}$ reaching $41.7 \% C_{R}$, while remaining almost constant in root litter at $49.1 \pm 1.3 \% C_{R}$. From 24 to 48 months the decrease was again similar, with an average of $6.4 \pm 0.7 \%$ from 24 to 36 and $8.1 \pm 0.9 \%$ of $C_{0}$ from 36 to 48 months, resulting in an overall lower $C$ loss in root as compared to leaf litter (35.5 and $26.8 \% C_{R}$ after 48 months, respectively). Further, $C_{R}$ also varied with the origin of the litter material, but this depended on altitude and litter type (Fig. 5a, Table 2). At each of the three altitudes $C_{R}$ in root litter from ECSF was higher than that of leaf litter from ECSF, while in litter from Caja this was only true at 1000 and $2000 \mathrm{~m} . \mathrm{C}_{R}$ in litter from Bomb did not vary significantly between leaf and root litter.

$\mathrm{C}_{\mathrm{c}}$ also varied significantly with time, litter type and altitude (Table 2, Fig. 3a). It decreased at each of the altitudes in both litter types from 6 to 12 months. In the following years the pattern varied, in both leaf and root litter exposed at 2000 and 3000 m C $C_{c}$ increased from 12 to 24 months and then remained almost constant in the following two years. At $1000 \mathrm{~m}$ variations in $C_{c}$ with time differed between leaf and root litter. In leaf litter it remained almost constant after 12 months at an average of $47.3 \pm 0.6 \%$, while in root litter it slowly decreased, but remained almost constant between 24 and 36 months.

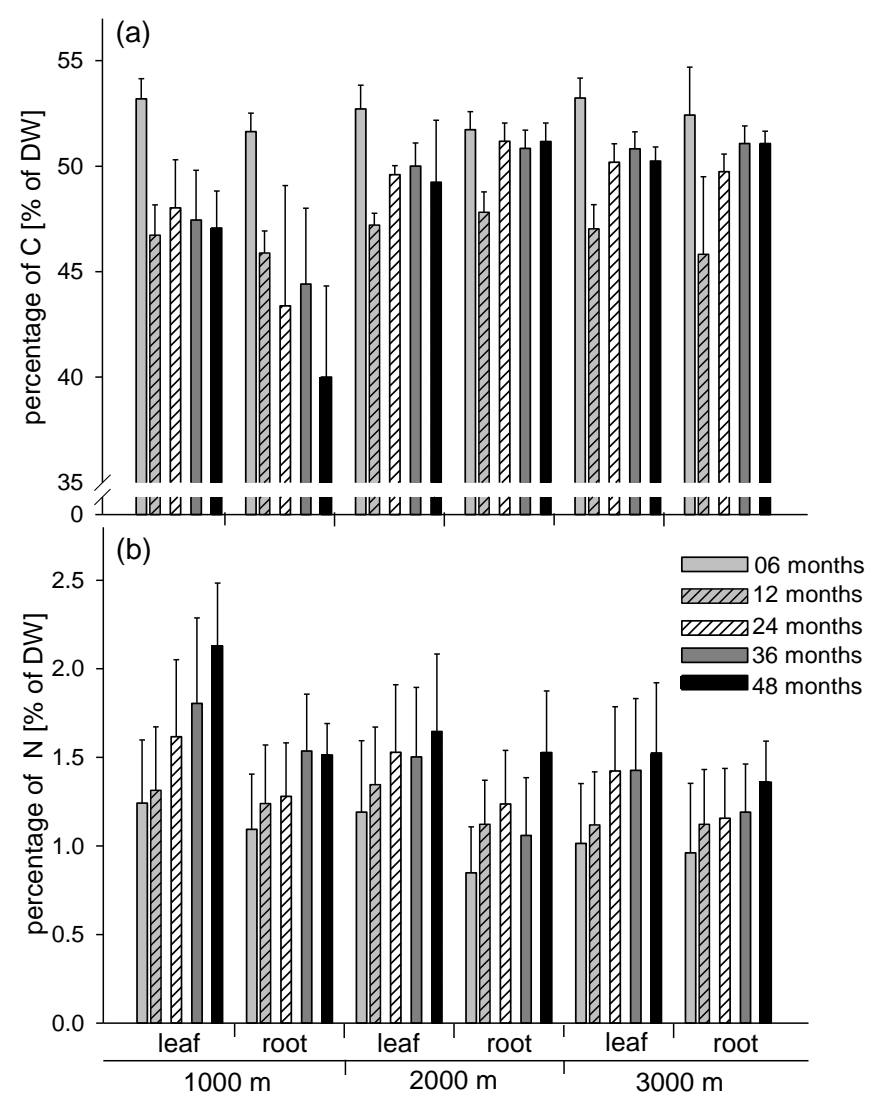

Fig. 3: Variation in the percentages (of dry weight) of $C\left(C_{C}\right)(a)$ and $N\left(N_{c}\right)(b)$ in leaf and root litter exposed in tropical montane rainforests at three altitudes $(1000,2000$ and $3000 \mathrm{~m})$ for 6, 12, 24,36 and 48 months (means $\pm S D)$. 
Overall, leaf litter contained slightly higher $C_{c}$ than root litter and at $1000 \mathrm{~m} \mathrm{C}_{\mathrm{c}}$ was generally lower due to stronger decrease with time. Further, $C_{C}$ also varied with time and origin of litter material (interaction: time $\times$ origin; Table 2 ) and this was mainly due to lower $\mathrm{C}_{\mathrm{c}}$ in the litter material from ECSF after 36 months. After 6 months litter from Bomb contained slightly less $C_{c}$ with $51.8 \%$ than litter from ECSF and Caja both with $52.8 \%$. The decrease from 6 to 12 months was strongest and did not vary with litter origin; on average it decreased to $46.8 \%$ of $C_{0}$. $C_{c}$ in litter from Bomb and Caja varied in a similar pattern increasing after 12 months by $1.2 \%$ and $2.5 \%$ in the second, and by $1.2 \%$ and $0.9 \%$ in the third year, respectively. From 36 to 48 months the decrease was identical with an average of $1.4 \pm 0.1 \%$ per year. In litter from ECSF $C_{c}$ only increased from 12 to 24 months by $2.0 \%$. From 24 to 36 it decreased by $1.0 \%$ and then stayed constant from 36 to 48 months, resulting in litter from Bomb and ECSF having a slightly lower $C_{c}$ after 48 months $(47.9 \pm 4.9$ and $48.0 \% C_{c}$, respectively) than litter from Caja $(48.7 \pm 4.3 \%)$.

Generally, except during the first 6 months, $N_{R}$ decreased with time, but this varied significantly with altitude (Fig. 2b, Table 2). After the first 6 months $N_{R}$ exceeded $N_{0}$ at 1000 m, whereas it uniformly decreased later. From 6 to 12 months the decrease was strongest with $47.5 \%$ of $\mathrm{N}_{0}$ and continued with an average of $12.9 \pm 2.0 \%$ of $\mathrm{N}_{0}$ each following year. At 2000 and $3000 \mathrm{~m}$ the pattern was less consistent. At both altitudes $N_{R}$ was close to $100 \%$ of $N_{0}$ after 6 months and decreased in the following 6 months to 82.4 and $77.7 \% \mathrm{~N}_{R}$, respectively. From 12 to 24 months it remained almost constant at $2000 \mathrm{~m}$, but at $3000 \mathrm{~m}$ it increased again to $94.9 \% \mathrm{~N}_{\mathrm{R}}$. From 24 to 36 months it decreased again to 70.6 and $84.1 \% N_{R}$ at 2000 and 3000 m, respectively. From 36 to 48 months changes were small. The decrease in $N_{R}$ also varied significantly between litter types (date $\times$ type interaction; Table 2), in both leaf and root litter the decline was strongest between 6 and 12 months. In leaf litter $N_{R}$ remained constant between 12 and 24 months followed by a decrease between 24 and 48 months. In root litter $N_{R}$ fluctuated after 12 months with an overall weaker decline than in leaf litter resulting in 54.5 compared to $69.2 \% \mathrm{~N}_{\mathrm{R}}$ after 48 months, respectively. The decrease in $N_{R}$ at the three altitudes also varied significantly with origin of the litter material (date $x$ altitude $\times$ origin interaction; Table 2). Overall, the decrease was most pronounced at $1000 \mathrm{~m}$, with only $17.0 \% \mathrm{~N}_{\mathrm{R}}$ in litter from Bomb after 48 months compared to 26.9 and $46.2 \%$ of $\mathrm{N}_{\mathrm{R}}$ in litter from Bomb and Caja, respectively. At higher altitudes the decrease was also at a maximum in litter from Bomb with 57.2 and $73.1 \% \mathrm{~N}_{\mathrm{R}}$ after 48 months at 2000 and $3000 \mathrm{~m}$, respectively, compared to 88.3 \% $\mathrm{N}_{R}$ in litter from ECSF and 81.2 \% $\mathrm{N}_{R}$ in litter from Caja at $2000 \mathrm{~m}$ and $76.9 \% \mathrm{~N}_{\mathrm{R}}$ in litter from ECSF and $86.5 \% \mathrm{~N}_{R}$ in litter from Caja at $3000 \mathrm{~m}$. The decrease in $\mathrm{N}_{\mathrm{R}}$ in the two litter types also varied significantly with origin of the litter (date $\times$ type $\times$ origin interaction; Table 2 ). In leaf litter from Bomb $\mathrm{N}_{\mathrm{R}}$ declined strongest with $45.1 \% \mathrm{~N}_{\mathrm{R}}$ after 48 months, compared to $62.4 \%$ and $55.9 \%$ $\mathrm{N}_{\mathrm{R}}$ after 48 months in leaf litter from ECSF and Caja, respectively. In root litter from Bomb and ECSF 
the $\mathrm{N}$ loss was very similar with an average of 56.4 and $64.6 \% \mathrm{~N}_{\mathrm{R}}$ after 48 months compared to $86.7 \% \mathrm{~N}_{\mathrm{R}}$ in root litter from Caja.

Generally, $\mathrm{N}_{c}$ increased with time, but this varied with altitude and litter type (Fig. 3b, Table 2). The $\mathrm{N}_{c}$ increase was strongest in leaf litter at $1000 \mathrm{~m}$, increasing by $0.9 \%$ between 6 and 48 months, and root litter at $2000 \mathrm{~m}$, increasing by $0.7 \%$ between 6 and 48 months (Fig. 3b). In the other treatments the $N_{c}$ increase varied between 0.4 and $0.5 \%$ over the course of 48 months. In leaf litter at 2000 and $3000 \mathrm{~m}$ the increase stopped between 24 and 36 months, while in root litter at $3000 \mathrm{~m}$ it stopped between 12 and 36 months. In contrast, $N_{c}$ in root litter at $2000 \mathrm{~m}$ decreased from 24 to 36 months. $N_{c}$ increased strongly in leaf litter at $1000 \mathrm{~m}$, while it increased less in root litter, remaining constant between 12 and 24 months as well as between 36 and 48 months. Overall, $\mathrm{N}_{\mathrm{c}}$ decreased with increasing altitude and was higher in leaf as compared to root litter. At the three altitudes the increase also varied with litter origin (date $\times$ altitude $\times$ origin interaction; Table 2 ). In litter from Bomb, which had the highest $\mathrm{N}_{\mathrm{c}}$, the total increase was lowest irrespective of altitude. At 1000 and $3000 \mathrm{~m}$ the increase in $\mathrm{N}_{\mathrm{c}}$ was most pronounced in litter from Caja, while at $2000 \mathrm{~m}$ it was most pronounced in litter from ECSF. In litter from Bomb and Caja $\mathrm{N}_{\mathrm{C}}$ decreased or remained constant between 24 and 36 months at both 2000 and $3000 \mathrm{~m}$. In both litter types the increase in $\mathrm{N}_{\mathrm{c}}$ also varied with the origin of the litter material (date $\times$ type $\times$ origin interaction; Table 2 ). The increase in $\mathrm{N}_{\mathrm{C}}$ from 6 to 48 months in the litter material from Bomb and ECSF was lower in roots than in leaf litter, with $0.4 \%$ as compared to $0.6 \%$ in litter from Bomb and $0.6 \%$ as compared to $0.7 \%$ in litter from ECSF, respectively. In litter from Caja $\mathrm{N}_{\mathrm{c}}$ in root litter almost doubled, increasing by $0.6 \%$ from 0.7 to $1.3 \% \mathrm{~N}_{c}$ as compared to only $4.8 \%$ in leaf litter from 0.9 to $1.4 \% \mathrm{~N}_{c}$.

\section{Microorganisms}

$\mathrm{C}_{\text {mic }}$, ergosterol concentration, $\mathrm{qO}_{2}$ and $\mathrm{C}_{\text {mic }}$-to- $\mathrm{C}_{\text {org }}$ ratio varied significantly with time, altitude and litter type (Tab. 3, Fig. 4). None of them increased or decreased steadily with time. $C_{\text {mic }}$ declined strongly from 6 to 24 months in both litter types at $2000 \mathrm{~m}$ and root litter at $3000 \mathrm{~m}$, followed by an increase from 24 to 36 months (Fig. 4a). In leaf litter at $3000 \mathrm{~m} \mathrm{C}_{\text {mic }}$ remained almost constant. In leaf litter at $1000 \mathrm{~m} \mathrm{C}_{\text {mic }}$ declined from 6 to 12 months, remained constant until 36 months and

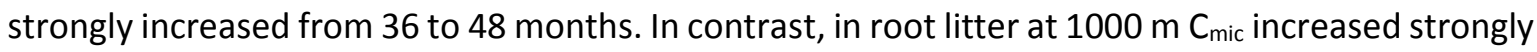
after 24 months followed by a similarly strong decrease (Fig. 4a). $C_{\text {mic }}$ also varied with the origin of the litter material (Table 3); it was highest in litter from Bomb followed by litter from ECSF and litter from Caja. Ergosterol concentrations decreased in leaf litter at 1000 and $2000 \mathrm{~m}$ from 6 to 24 months by 56.4 and $63.1 \%$, respectively (Fig. 4b), parallel to the strong decrease in $C_{\text {mic }}$ (Fig. 4a). In root litter at 1000 and $2000 \mathrm{~m}$ ergosterol concentrations did not vary significantly with time. At $3000 \mathrm{~m}$ ergosterol concentrations in leaf litter increased from 6 to 12 months, while in root litter 
they only increased from 12 to 24 months contrasting the decrease in $\mathrm{C}_{\text {mic }}$. Ergosterol concentrations also varied significantly with time and litter origin (date $\times$ origin interaction; Table 3). They were highest in the litter from ECSF after 6 months with $0.25 \mu \mathrm{g} \mathrm{g}^{-1} \mathrm{C}$ and decreased continuously, reaching $0.14 \mu \mathrm{g} \mathrm{g}^{-1} \mathrm{C}$ after 24 months. In litter from Bomb and Caja the variation with time was less pronounced, with $0.16 \mu \mathrm{g} \mathrm{g}^{-1} \mathrm{C}$ in litter from both origins after 6 months and 0.17 and $0.14 \mu \mathrm{g} \mathrm{g}^{-1} \mathrm{C}$ in litter from Bomb and Caja after 24 months, respectively.

Table 3: Repeated measured ANOVA/GLM table of F- and p-values, of the effects of altitude (1000, 2000 and $3000 \mathrm{~m}$ ), type (roots or leaves), origin (Bombuscaro (Bomb), ECSF and Cajanuma (Caja)) and date (6, 12, 24, 36 and 48 months) on the microbial biomass $\left(\mathrm{C}_{\mathrm{mic}}\right)$, metabolic oxygen quotient $\left(\mathrm{qO}_{2}\right), \mathrm{C}_{\text {mic }}$-to- $\mathrm{C}_{\text {org }}$ ratio and ergosterol concentration (ergosterol/Corg). Significant effects are given in bold.

\begin{tabular}{|c|c|c|c|c|c|c|c|c|}
\hline & \multicolumn{2}{|c|}{$\mathrm{C}_{\text {mic }}$} & \multicolumn{2}{|c|}{$\mathrm{qO}_{2}$} & \multicolumn{2}{|c|}{$\mathrm{C}_{\text {mic }}$-to- $\mathrm{C}_{\text {org }}$ ratio } & \multicolumn{2}{|c|}{ ergosterol } \\
\hline & F-value & p-value & F-value & p-value & F-value & p-value & F-value & p-value \\
\hline \multicolumn{9}{|l|}{ Between subject effects } \\
\hline altitude & 15.08 & $<.0001$ & 16.20 & $<.0001$ & 16.01 & $<.0001$ & 13.55 & $<.0001$ \\
\hline origin & 8.77 & 0.0007 & 2.17 & 0.1299 & 11.18 & 0.0002 & 2.71 & 0.0762 \\
\hline type & 0.02 & 0.8868 & 0.01 & 0.9248 & 0.40 & 0.5307 & 90.31 & $<.0001$ \\
\hline altitude $\times$ origin & 2.04 & 0.1083 & 3.43 & 0.0185 & 3.65 & 0.0135 & 4.21 & 0.0051 \\
\hline altitude $\times$ type & 9.11 & 0.0006 & 1.16 & 0.3241 & 11.11 & 0.0002 & 12.67 & $<.0001$ \\
\hline origin $\times$ type & 0.37 & 0.6937 & 2.62 & 0.0872 & 0.66 & 0.5227 & 8.48 & 0.0007 \\
\hline altitude $\times$ origin $\times$ type & 1.70 & 0.1694 & 2.77 & 0.0429 & 1.46 & 0.234 & 1.64 & 0.1785 \\
\hline \multicolumn{9}{|l|}{ Within subject effects } \\
\hline date & 22.63 & $<.0001$ & 12.33 & $<.0001$ & 12.9 & $<.0001$ & 19.96 & $<.0001$ \\
\hline date $\times$ altitude & 8.16 & $<.0001$ & 3.36 & 0.0015 & 7.55 & $<.0001$ & 13.61 & $<.0001$ \\
\hline date $\times$ origin & 1.94 & 0.0581 & 0.79 & 0.6128 & 2.08 & 0.0419 & 5.19 & 0.0008 \\
\hline date $\times$ type & 2.98 & 0.0210 & 1.58 & 0.1825 & 2.40 & 0.0525 & 13.23 & $<.0001$ \\
\hline date $\times$ altitude $\times$ origin & 0.85 & 0.6314 & 1.41 & 0.1455 & 1.06 & 0.3984 & 1.31 & 0.2484 \\
\hline date $\times$ altitude $\times$ type & 6.31 & $<.0001$ & 5.54 & $<.0001$ & 4.92 & $<.0001$ & 3.45 & 0.0110 \\
\hline date $\times$ origin $\times$ type & 0.83 & 0.5745 & 0.91 & 0.5102 & 0.51 & 0.8482 & 1.87 & 0.1208 \\
\hline date $\times$ altitude $\times$ origin $\times$ type & 1.51 & 0.1033 & 1.07 & 0.3942 & 0.97 & 0.4958 & 0.55 & 0.8139 \\
\hline
\end{tabular}

Changes in $\mathrm{qO}_{2}$ contrasted those of $\mathrm{C}_{\text {mic }}$, increasing strongly from 12 to 24 months in both litter types at $2000 \mathrm{~m}$ and root litter at $3000 \mathrm{~m}$ (Fig. 4c, Table 3), while in leaf litter at $3000 \mathrm{~m}$ it only decreased from 6 to 12 months. At $1000 \mathrm{~m} \mathrm{qO}_{2}$ decreased in root litter from 6 to 24 months, while increasing in leaf litter from 12 to 24 months. The $\mathrm{qO}_{2}$ was generally lowest after 48 months. The $\mathrm{qO}_{2}$ also varied significantly with litter origin, but the variation depended on altitude and litter type (Fig. 5b, Table 3). Root litter from Caja had higher $\mathrm{qO}_{2}$ values than root litter from Bomb and ECSF, irrespective of altitude. The $\mathrm{qO}_{2}$ in leaf litter at $1000 \mathrm{~m}$ was highest in litter from Caja followed by litter from Bomb and litter from ECSF. At $2000 \mathrm{~m} \mathrm{qO}_{2}$ values in leaf litter from Bomb and Caja where almost identical while in litter from ECSF qO 2 was $10.7 \%$ higher. At $3000 \mathrm{~m}$ litter from ECSF and Caja had similar $\mathrm{qO}_{2}$ values while in litter from Bomb it was $13.3 \%$ lower. 

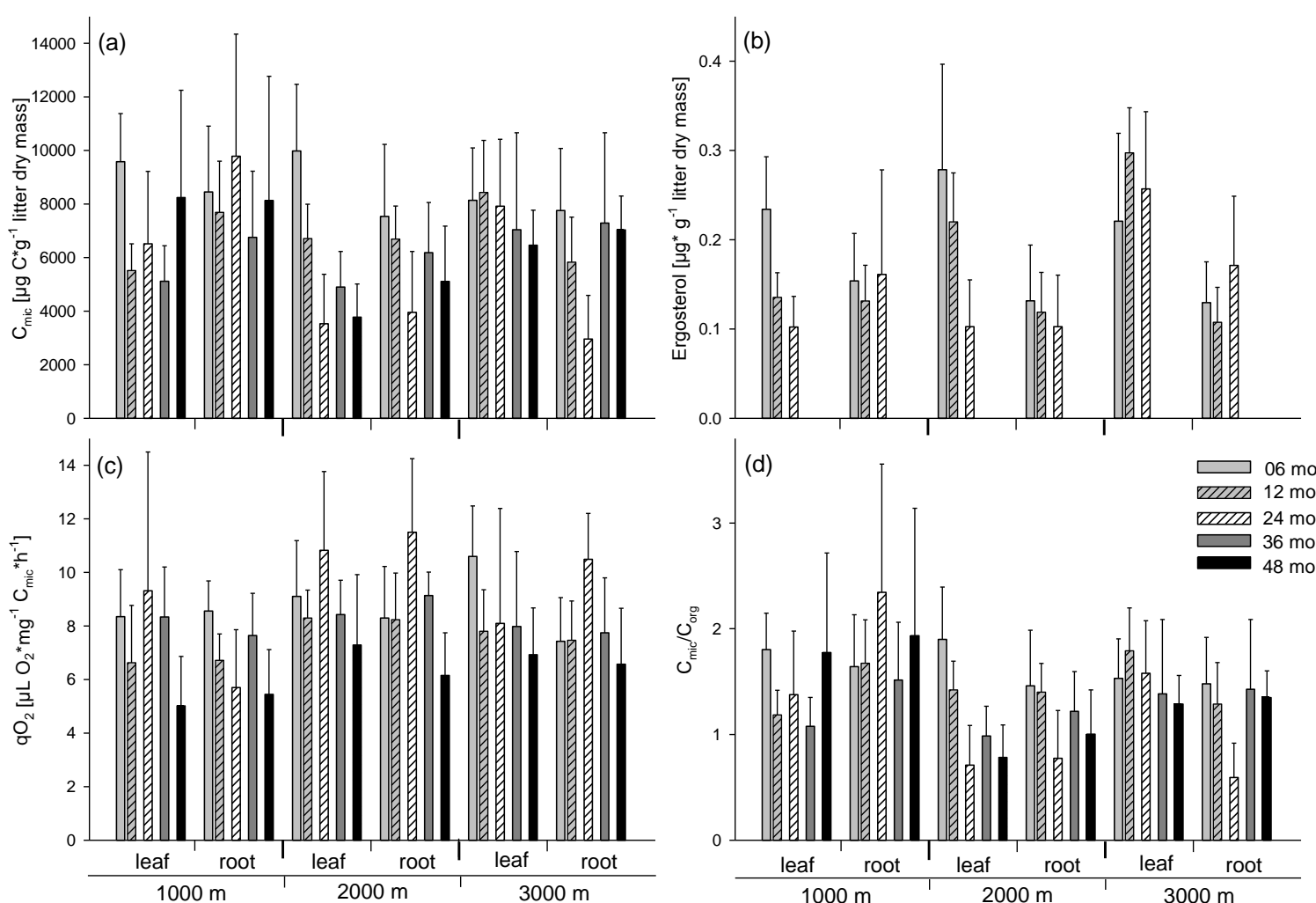

Fig. 4: Variation in microbial biomass $\left(\mathrm{C}_{\mathrm{mic}}\right)(\mathrm{a})$, ergosterol concentration (b), metabolic oxygen quotient $\left(\mathrm{qO}_{2}\right)$ (c) and $\mathrm{C}_{\text {mic }}$-to- $\mathrm{C}_{\text {org }}$ ratio (d) in leaf and root litter exposed in tropical montane rainforests at three altitudes (1000, 2000 and $3000 \mathrm{~m}$ ) for 6, 12, 24,36 and 48 months (means $\pm S D$ ).
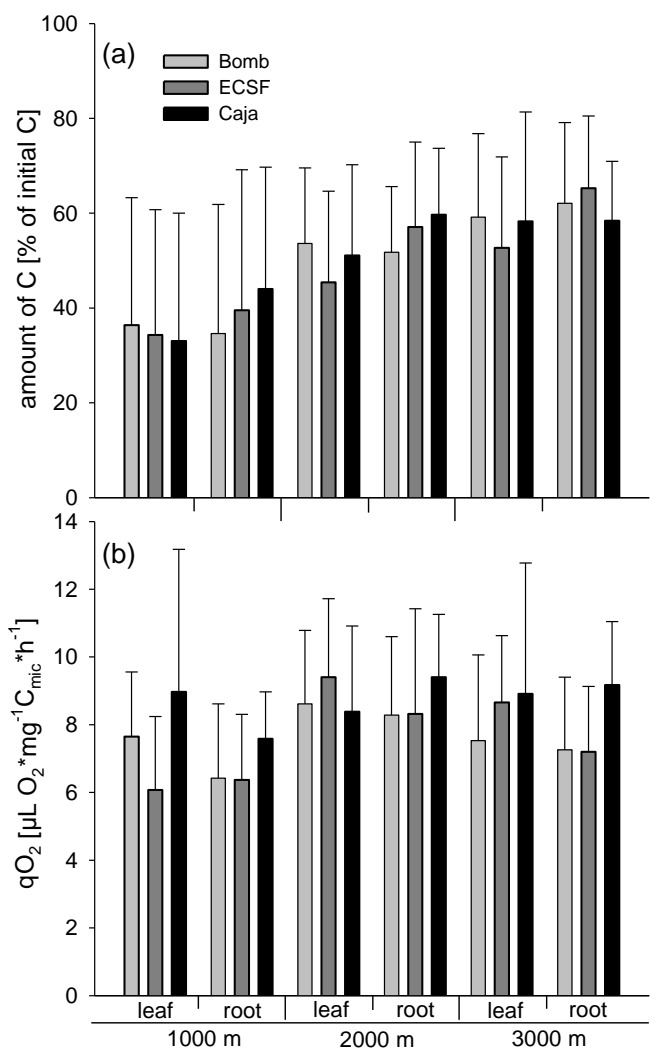

Fig. 5: Variation in the amount of $C$ remaining $\left(C_{R}\right.$; percentages of initial; $\left.C_{0}\right)(a)$ and the metabolic oxygen quotient $\left(\mathrm{qO}_{2}\right)(\mathrm{b})$ in leaf and root litter from three altitudes (Bomb, ECSF and Caja) exposed in tropical montane rainforests at three altitudes $(1000,2000$ and $3000 \mathrm{~m})$ (means \pm SD). 
The $\mathrm{C}_{\text {mic }}$-to- $\mathrm{C}_{\text {org }}$ ratio closely correlated with $\mathrm{C}_{\text {mic }}$ (see Appendix Table S3 and S4). It declined strongly from 6 to 24 months in both litter types at $2000 \mathrm{~m}$ and root litter at $3000 \mathrm{~m}$, followed by an increase from 24 to 36 months and remained almost constant in leaf litter at $3000 \mathrm{~m}$ (Fig. 4d, Table 3). The $\mathrm{C}_{\text {mic }}$-to- $\mathrm{C}_{\text {org }}$ ratio at $1000 \mathrm{~m}$ declined from 6 to 12 months in leaf litter and remained constant until 36 months, followed by a strong increase from 36 to 48 months, while in root litter it strongly increased from 12 to 24 months, parallel to the variations in $C_{\text {mic }}$. The $C_{\text {mic }}$-to- $C_{\text {org }}$ ratio also varied significantly with time and litter origin (date $\times$ origin interaction; Table 3). It decreased in litter from Bomb and ECSF from 6 to 36 months, from 2.0 and 1.7 after 6 months to 1.4 and 1.2 after 36 months, respectively. From 36 to 48 months the $C_{\text {mic }}$-to- $C_{\text {org }}$ ratio increased to 1.5 in litter from Bomb and 1.4 in litter from ECSF. In litter from Caja the $C_{\text {mic }}$-to- $C_{\text {org }}$ ratio was more variable and reached a minimum of 0.9 after 24 months.

\section{Discussion}

Decomposition processes have been shown to strongly depend on the quality of litter material, especially in the early phase of decomposition (Berg \& McClaugherty, 2008; Cusack et al., 2009). In contrast to this view, in the present study the origin and therefore quality of the litter material was of minor importance, influencing $C$ loss only in the early phase of decomposition. Generally, however, at later phases of decomposition $\mathrm{C}$ mass loss of litter was mainly affected by the altitude at which the litter material was exposed and therefore by site specific biotic and abiotic conditions rather than by litter quality.

Decomposition processes are known to undergo different stages with the early stage being characterized by fast mass loss through leaching of soluble compounds and decomposition of holocellulose (Berg \& McClaugherty, 2008; Berg, 2014). Our results support this view, with a rapid decline in the amount of litter $\mathrm{C}$ within the first year of decomposition irrespective of altitude. Berg (2014) described that in the later phases of decomposition the rate of mass and $\mathrm{C}$ loss slows down and is dominated by the degradation of lignified litter compounds. The decomposition rate can even cease, reaching a limit value and leaving behind stable litter compounds which are little decomposed (Berg \& McClaugherty, 2008; Berg, 2014). In the present study the C loss rate in later phases (after 12 months) varied between altitudes. Butenschoen et al. (2014) already reported a strong decrease in litter mass in the first year followed by slowing down or ceasing of decomposition rates from 12 to 24 months in a litterbag experiment at the $2000 \mathrm{~m}$ study site of the present study. Results of the present study support these findings and document that the retardation in decomposition rate and C loss at 2000 and $3000 \mathrm{~m}$ starts after 12 months and lasts then for at least 24 months, with the amount of litter C staying constant at a limit value of around $50 \%$ of $C_{0}$. After this second phase of litter decomposition, the loss of $C$ resumed from 36 to 48 
months at 2000 and $3000 \mathrm{~m}$, however, at a low rate of $8-9 \%$ of $C_{0}$. This resumption of $C$ loss indicates a third phase of decomposition, which likely is associated with the start of lignin degradation and a shift in the decomposer community towards lignin decomposing microorganisms. The long delay before this resumption of decomposition suggests that lignin degrading organisms were outcompeted in the early phase of decomposition by primary colonisers which use the fast decomposable soluble litter compounds as resource. In contrast, at $1000 \mathrm{~m} \mathrm{C}$ loss continued after 12 months at a low but steady rate of around $10 \%$ of $\mathrm{C}_{0}$ each year, reaching over $80 \% \mathrm{C}$ loss after 4 years, indicating that in contrast to higher altitudes site specific conditions at $1000 \mathrm{~m}$ promote litter decomposition including recalcitrant compounds such as lignin. Presumably, the different forest floor types at the different altitudes with the litter layer being in close contact with mineral soil at $1000 \mathrm{~m}$ whereas thick layers of F-material separating leaf litter and mineral soil at higher altitudes contribute to the different decomposition dynamics. Soil characteristics are known to influence decomposition (Berg \& McClaugherty, 2008), for example by supporting a stable microbial community by enabling them to acquire $\mathrm{N}$ from the inorganic $\mathrm{N}$ pool in soil (Hodge et al., 2000) and therefore increasing decomposition rates. At $1000 \mathrm{~m}$ the thin litter layer ( $L$ layer) on top of the mineral soil ( $A_{h}$ layer) enables direct interactions between microorganisms of the litter and mineral soil while at the higher altitude sites the litter layer overtops thick layers of decomposed organic material ( $F$ layer) and therefore, is separated from the mineral soil. This might result in a feedback loop in which accumulation of organic material and the formation of thick $\mathrm{F}$ layers inhibits further decomposition.

Irrespective of altitude the pattern of inhibited C loss after 12 months was more pronounced in root litter, while in leaf litter $\mathrm{C}$ mass loss continued at a low rate. Presumably, this is due to root litter containing higher concentrations of lignin than leaf litter (Bloomfield et al., 1993; Berg \& McClaugherty, 2008), resulting in a stronger accumulation of lignified litter compounds in later phases of decomposition causing slowed down or ceasing decomposition rates. This is especially relevant for the accumulation of large amounts of little decomposed root litter at 2000 and $3000 \mathrm{~m}$, since the root-to-shoot ratio in the studied area is increased at higher altitude (Leuschner et al., 2007).

The concentration of $C$ in the litter material $\left(C_{C}\right)$ remained very high over the course of the experiment, indicating an overall high concentration of highly condensed carbon compounds such as lignin (Berg \& McClaugherty, 2008). Only in root litter at 1000 m C $c$ decreased continuously with time, indicating continuous degradation of recalcitrant condensed compounds. At higher altitudes, but also in leaf litter at $1000 \mathrm{~m}, \mathrm{C}_{\mathrm{c}}$ only decreased from 6 to 12 months and increased strongly from 12 to 24 month, supporting our conclusion of inhibited lignin degradation and therefore accumulation of recalcitrant compounds in the second phases of decomposition. 
Berg and McClaugherty (2008) stated that the retardation in mass loss during later phases of decomposition is not only caused by high lignin concentration, but also due to negative effects of increased $\mathrm{N}$ concentrations. While high concentrations of $\mathrm{N}$ increase litter decomposition at early stages of litter decay, they suppress the degradation of recalcitrant compounds by repressing the formation of lignolytic enzymes (Keyser et al., 1978; Berg \& McClaugherty, 2008; Berg, 2014). Early during litter decomposition $\mathrm{N}_{\mathrm{C}}$ in the present study ranged from 0.6 to $1.4 \%$. During exposure $\mathrm{N}_{\mathrm{C}}$ in the litter increased at each of the altitudes and in both litter types. High $\mathrm{N}_{c}$ in leaf litter at $1000 \mathrm{~m}$ might explain the high $\mathrm{C}_{c}$, due to inhibited lignin degradation, at this altitude compared to root litter (Cusack et al., 2009). The initial $\mathrm{N}_{\mathrm{c}}$ in litter from the different altitudes influenced the pattern in which $N_{c}$ varied with time. In litter material with initially high $N_{c}$ values, the increase with time was less pronounced than in litter material with low $N_{c}$, suggesting that $N_{c}$ values converge with time.

The amount of $\mathrm{N}$ in the litter material $\left(\mathrm{N}_{\mathrm{R}}\right)$ increased in the first 6 months at $1000 \mathrm{~m}$ and remained constant at 2000 and $3000 \mathrm{~m}$, indicating that at $1000 \mathrm{~m}$ fungal hyphae transported $\mathrm{N}$ into the litter thereby improving conditions for litter decomposition in the early decomposition phase. After 6 months, however, $\mathrm{N}_{\mathrm{R}}$ started to decrease, suggesting that $\mathrm{N}$ from the litter material was mobilized and transported out of the litterbags. At $1000 \mathrm{~m} \mathrm{~N}_{\mathrm{R}}$ decreased from 12 months onwards. Together with the continuous loss of $\mathrm{C}$ at $1000 \mathrm{~m}$ this suggests that also recalcitrant compounds were decomposed. At 2000 and $3000 \mathrm{~m} \mathrm{~N}_{\mathrm{R}}$ decreased by less than $30 \%$ of $\mathrm{N}_{0}$, and this decrease mainly occurred between 6 and 12 months of exposure in the field, suggesting that during this early phase export of litter $\mathrm{N}$ was at a maximum, while at later phases of decomposition litter $\mathrm{N}$ was retained in the litter. The C-to- $\mathrm{N}$ ratio of litter at 2000 and $3000 \mathrm{~m}$ was high (ranging from 97 to 32 over the course of the experiment) and exceeded values at which net mineralisation is assumed to occur (25) (Hodge et al., 2000). This suggests that plant roots at the study site are unable to obtain $\mathrm{N}$ from decomposing litter. Presumably, plants rely on mycorrhizal fungi improving $\mathrm{N}$ capture by growing into leaf and root litter material. Indeed, the great majority of tree species at our study sites are associated with AM fungi (Haug et al., 2004; Kottke et al., 2004). AM fungi, while unable to decompose complex organic molecules themselves, are known to stimulate $\mathrm{N}$ uptake by plants and improve decomposition by interacting with the microbial community (Coleman, 1994; Hodge et al., 2001; Koller et al., 2013b,c). Presumably, in particular at the 2000 and $3000 \mathrm{~m}$ sites the microbial community heavily relies on mycorrhizal C provided via hyphal exudates (Bonkowski, 2004; Koller et al., 2013c). Potentially, this $C$ input enabled the microbial community to obtain $\mathrm{N}$ from the litter material, despite the high C-to- $\mathrm{N}$ ratio (Koller et al., 2013a). In fact, irrespective of litter C-to-N ratios protozoa mobilise microbially fixed $\mathrm{N}$ by grazing on bacteria, and AM fungi translocate the mobilised $\mathrm{N}$ to the host plant (Koller et al., 2013b). Notably, Krashevska et al. (2008) suggested 
testate amoebae, a major group of protists at our study site, to be driven by the availability of bacteria and fungi as food source.

Overall, microbial biomass was low as compared to temperate regions, resembling results from previous studies at our study sites and other tropical forests (Luizao et al., 1992; Imberger \& Chiu, 2002; Krashevska et al., 2008). Krashevska (2008) investigating the same altitudinal transect found $\mathrm{C}_{\text {mic }}$ and ergosterol in the litter layer to peak at $2000 \mathrm{~m}$, while in the present study $\mathrm{C}_{\text {mic }}$ and ergosterol concentrations only peaked at this altitude in leaf litter after 6 months. At all other dates they either increased with increasing altitude or were reduced at $2000 \mathrm{~m}$ after 24 months. Krashevska et al. (2008) also reported high ergosterol concentrations in the upper litter layer. Results of the present study support these findings as ergosterol concentrations in leaf litter exceeded those in root litter irrespective of altitude after 6 months.

The structure and functioning of the microbial community in decomposing litter material is known to change during decomposition, parallel to changes in the chemical composition of the litter material (Scheu \& Parkinson, 1995; Berg \& McClaugherty, 2008). In the present study, this linkage between changes in litter chemistry and microbial community composition was evident throughout the decomposition process. While the origin and therefore quality of the litter material affected the microbial community mainly in the early phase of decomposition, site specific conditions, i.e. altitude, became more important later. At each altitude the fast decrease in $C_{R}$ and $N_{R}$ from 6 to 12 months as well as the generally high $C_{\text {mic }}$ and $C_{\text {mic }}$-to- $C_{\text {org }}$ ratio after 6 months support the hypothesis that the early microbial community depended mainly on easily decomposable litter compounds. This also is reflected by high $\mathrm{C}_{\text {mic }}$ and $\mathrm{C}_{\text {mic }}$-to- $\mathrm{C}_{\text {org }}$ ratios in litter material from Bomb which had the lowest C-to-N ratio. The ergosterol concentration only decreased from 6 to 12 months in leaf litter at 1000 and $2000 \mathrm{~m}$, indicating that saprotrophic fungi in these treatments also depended on easily decomposable litter compounds.

Differences in the rate of $\mathrm{C}$ mass loss between altitudes after 12 months presumably are related to

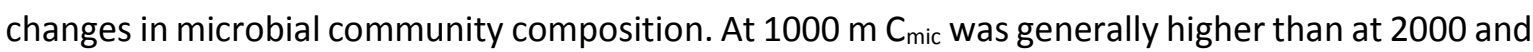
$3000 \mathrm{~m}$ and decomposition of litter continued after 12 months suggesting that microorganisms at this altitude were able to continuously decompose condensed litter compounds including lignin thereby reducing $C_{C}$ and $C_{R}$. Presumably, contact of litter and mineral soil as well as higher quality of the surrounding local litter material at $1000 \mathrm{~m}$ (Wilcke et al., 2002) improved the ability of the microbial community to decompose litter. Contrasting the conditions at 2000 and $3000 \mathrm{~m}$ where the separation of the leaf litter layer from mineral soil and low nitrogen concentration of F-material may hamper translocation of $\mathrm{N}$ into the litter material, causing the litter to remain poor in $\mathrm{N}$; in fact, both leaf and root litter at 2000 and $3000 \mathrm{~m}$ still were poor in $\mathrm{N}$ with average $\mathrm{C}$-to-N ratios of $33.7 \pm 9.0$ and $36.7 \pm 8.2$ after 48 months, respectively, whereas at $1000 \mathrm{~m}$ litter $\mathrm{N}$ was higher with 
an average C-to-N ratio of $24.8 \pm 4.7$ after 48 months. In both leaf and root litter at $2000 \mathrm{~m}$ and root litter at $3000 \mathrm{~m}$ the strong decrease in $\mathrm{C}_{\mathrm{mic}}$ and $\mathrm{C}_{\text {mic }}$-to- $\mathrm{C}_{\text {org }}$ ratio from 6 to 24 months indicates that the early microbial community depending on easily decomposable litter compounds declined due to substrate depletion. $\mathrm{High} \mathrm{qO}_{2}$ during this phase suggests that increased stress contributed to the decline in $C_{m i c}$ (Blagodatskaya \& Anderson, 1999). After 24 months $C_{m i c}$ and the $C_{\text {mic }}$-to- $C_{\text {org }}$ ratio increased while $\mathrm{qO}_{2}$ decreased, indicating a shift in the structure of the microbial community. This suggests that after depletion of easily decomposable litter compounds in the first phase of decomposition, the activity of the microbial community slowed down or ceased in the second phase between 12 and 36 months. Resumption of litter decomposition at 2000 and $3000 \mathrm{~m}$ in the third phase after 36 months suggests that a novel microbial community able to decompose condensed recalcitrant litter compounds including lignin took over. Slower decline in $\mathrm{C}_{\text {mic }}$ and $\mathrm{C}_{\text {mic }}$-to- $\mathrm{C}_{\text {org }}$ ratio and higher ergosterol concentration in leaf litter at $3000 \mathrm{~m}$ as compared to $2000 \mathrm{~m}$ indicates that this shift in microbial community composition was less strong in leaf litter at $3000 \mathrm{~m}$ as compared to root litter and both litter types at $2000 \mathrm{~m}$. Presumably, at $3000 \mathrm{~m}$ where organic layers are most pronounced reaching a thickness of more than $40 \mathrm{~cm}$ (Graefe et al., 2008) dominance of saprotrophic fungi in the upper litter layer is most pronounced.

\section{Conclusions}

Results of the present long term study suggest that the accumulation of dead organic material at higher altitude and the formation of thick $\mathrm{F}$ layers in tropical montane rainforests in part is caused by reduced or ceasing decomposition rates in both leaf and root litter in a second phase of decomposition between 12 and 36 months as well as slow resumption of litter decomposition after this phase. Continuous litter decomposition at 1000 m suggests that these long term decomposition patterns are not caused by differences in litter quality, but by site specific conditions such as different forest floor types as well as different trophic interactions between plants and the belowground community. We suggest that the accumulation of leaf and root litter at high altitudes and therefore the formation of thick layers of organic material ( $F$ layer) inhibits positive interactions between the microbial community in the upper litter layer and the mineral soil, causing the microbial community to depend on plant-derived resources only, with the litter poor in $\mathrm{N}$ being insufficient to allow saprotrophic microorganisms to effectively decompose in particular condensed litter compounds such as lignin. We suggest that these conditions lead to closer trophic linkage between plants and the decomposer community at higher altitude. Future studies need to elucidate interactions between the plant and the decomposer community, to disentangle how plant-derived resources impact the belowground community structure, decomposition processes and the capture of nutrients from decomposing litter by plants. 


\section{Acknowledgements}

Financial support was provided by the German Science Foundation (DFG) within the scope of the Research Unit 816 "Tropical Mountain Forest (TMF) Biodiversity \& Sustainable Management of a Mega Diverse Mountain Ecosystem in South Ecuador".

Measurements of $\mathrm{C}$ and $\mathrm{N}$ contents were performed by Ute Schlonsog in the laboratory of Prof. Dr. Christoph Leuschner (Göttingen/Germany). Ergosterol measurements were performed by Gabriele Dormann in the laboratory of Prof. Dr. Rainer Georg Joergensen (Kassel/Witzenhausen/Germany). We thank the German and Ecuadorian students and helpers for their support in the establishment of the experimental field sites, with collection of samples and their work in the laboratory.

\section{References}

Allison SD, Treseder KK. 2008. Warming and drying suppress microbial activity and carbon cycling in boreal forest soils. Global Change Biology 14: 2898-2909.

Allison SD, Wallenstein MD, Bradford MA. 2010. Soil-carbon response to warming dependent on microbial physiology. Nature Geoscience 3: 336-340.

Anderson JPE, Domsch KH. 1978. A physiological method for the quantitative measurement of microbial biomass in soils. Soil Biology and Biochemistry 10: 215-221.

Averill C, Turner BL, Finzi AC. 2014. Mycorrhiza-mediated competition between plants and decomposers drives soil carbon storage. Nature 505: 543-545.

Barthlott W, Mutke J, Rafiqpoor D, Kier G, Kreft H. 2005. Global centers of vascular plant diversity. Nova Acta Leopoldina 92: 61-83.

Beck T, Joergensen RG, Kandeler E, Makeschin F, Nuss E, Oberholzer HR, Scheu S. 1997. An interlaboratory comparison of ten different ways of measuring soil microbial biomass C. Soil Biology and Biochemistry 29: 1023-1032.

Berg B. 2014. Decomposition patterns for foliar litter - A theory for influencing factors. Soil Biology and Biochemistry 78: 222-232.

Berg B, McClaugherty C. 2008. Plant Litter: Decomposition, Humus Formation, Carbon Sequestration. Berlin, Heidelberg: Springer Verlag.

Blagodatskaya E V., Anderson T-H. 1999. Adaptive responses of soil microbial communities under experimental acid stress in controlled laboratory studies. Applied Soil Ecology 11: 207-216.

Bloomfield J, Vogt KA, Vogt DJ. 1993. Decay rate and substrate quality of fine roots and foliage of two tropical tree species in the Luquillo Experimental Forest, Puerto Rico. Plant and Soil 150: $233-245$.

Bonkowski M. 2004. Protozoa and plant growth: the microbial loop in soil revisited. New Phytologist 162: 617-631.

Bonkowski M, Clarholm M. 2012. Stimulation of plant growth through interactions of bacteria and protozoa: Testing the auxiliary microbial loop hypothesis. Acta Protozoologica 51: 237-247. 
Butenschoen O, Krashevska V, Maraun M, Marian F, Sandmann D, Scheu S. 2014. Litter mixture effects on decomposition in tropical montane rainforests vary strongly with time and turn negative at later stages of decay. Soil Biology and Biochemistry 77: 121-128.

Cleveland CC, Reed SC, Keller AB, Nemergut DR, O'Neill SP, Ostertag R, Vitousek PM. 2014. Litter quality versus soil microbial community controls over decomposition: a quantitative analysis. Oecologia 174: 283-294.

Coleman DC. 1994. The microbial loop concept as used in terrestrial soil ecological studies. Microbial ecology 28: 245-250.

Coûteaux M-M, Sarmiento L, Bottner P, Acevedo D, Thiéry JM. 2002. Decomposition of standard plant material along an altitudinal transect $(65-3968 \mathrm{~m})$ in the tropical Andes. Soil Biology and Biochemistry 34: 69-78.

Cox PM, Pearson D, Booth BB, Friedlingstein P, Huntingford C, Jones CD, Luke CM. 2013. Sensitivity of tropical carbon to climate change constrained by carbon dioxide variability. Nature 494: 341-344.

Cusack DF, Chou WW, Yang WH, Harmon ME, Silver WL. 2009. Controls on long-term root and leaf litter decomposition in neotropical forests. Global Change Biology 15: 1339-1355.

Davidson EA, Janssens IA. 2006. Temperature sensitivity of soil carbon decomposition and feedbacks to climate change. Nature 440: 165-173.

Dieleman WIJ, Venter M, Ramachandra A, Krockenberger AK, Bird MI. 2013. Soil carbon stocks vary predictably with altitude in tropical forests: Implications for soil carbon storage. Geoderma 204: 59-67.

Djajakirana G, Joergensen RG, Meyer B. 1996. Ergosterol and microbial biomass relationship in soil. Biol Fertil Soils 22: 299-304.

Fang C, Smith P, Moncrieff JB, Smith JU. 2005. Similar response of labile and resistant soil organic matter pools to changes in temperature. Nature 433: 57-59.

Fierer N, Craine JM, McLauchlan K, Schimel JP. 2005. Litter quality and the temperature sensitivity of decomposition. Ecology 86: 320-326.

Fierer N, Strickland MS, Liptzin D, Bradford MA, Cleveland CC. 2009. Global patterns in belowground communities. Ecology letters 12: 1238-1249.

Frey SD, Lee J, Melillo JM, Six J. 2013. The temperature response of soil microbial efficiency and its feedback to climate. Nature Climate Change 3: 395-398.

Giardina CP, Ryan MG. 2000. Evidence that decomposition rates of organic carbon in mineral soil do not vary with temperature. Nature 404: $858-861$.

Girardin CAJ, Malhi Y, Aragão LEOC, Mamani M, Huaraca Huasco W, Durand L, Feeley KJ, Rapp J, Silva-Espejo JE, Silman M, et al. 2010. Net primary productivity allocation and cycling of carbon along a tropical forest elevational transect in the Peruvian Andes. Global Change Biology 16: 3176-3192.

Gorham E. 1991. Northern peatlands: Role in the carbon cycle and probable responses to climatic warming. Ecological Applications 1: 182-195.

Graefe S, Hertel D, Leuschner C. 2008. Fine root dynamics along a 2,000 m elevation transect in South Ecuadorian mountain rainforests. Plant and Soil 313: 155-166. 
Haug I, Lempe J, Homeier J, Weiß M, Setaro S, Oberwinkler F, Kottke I. 2004. Graffenrieda emarginata (Melastomataceae) forms mycorrhizas with Glomeromycota and with a member of the Hymenoscyphus ericae aggregate in the organic soil of a neotropical mountain rain forest. Canadian Journal of Botany 82: 340-356.

Henderson A, Churchill SP, Luteyn JL. 1991. Neotropical plant diversity. Nature 351: 21-22.

Heneghan L, Coleman DC, Zou X, Crossley DA, Haines BL. 1999. Soil microarthropod contributions to decomposition dynamics: Tropical-temperate comparisons of a single substrate. Ecology 80: 1873-1882.

Hilt N, Fiedler K. 2005. Diversity and composition of Arctiidae moth ensembles along a successional gradient in the Ecuadorian Andes. Diversity and Distributions 11: 387-398.

Hodge A, Campbell CD, Fitter AH. 2001. An arbuscular mycorrhizal fungus accelerates decomposition and acquires nitrogen directly from organic material. Nature 413: 297-299.

Hodge A, Robinson D, Fitter A. 2000. Are microorganisms more effective than plants at competing for nitrogen? Trends in Plant Science 5: 304-308.

Homeier J, Breckle S-W, Günter S, Rollenbeck RT, Leuschner C. 2010. Tree diversity, forest structure and productivity along altitudinal and topographical gradients in a species-rich Ecuadorian montane rain forest. Biotropica 42: 140-148.

Homeier J, Dalitz H, Breckle S-W. 2002. Waldstruktur und Baumdiversität im montanen Regenwald der Estación Cientifíca San Francisco in Südecuador. Bericht der Reinhessischen TüxenGesellschaft 14: 109-118.

Illig J, Schatz H, Scheu S, Maraun M. 2008. Decomposition and colonization by micro-arthropods of two litter types in a tropical montane rain forest in southern Ecuador. Journal of Tropical Ecology 24: 157-167.

Imberger KT, Chiu C-Y. 2002. Topographical and seasonal effects on soil fungal and bacterial activity in subtropical, perhumid, primary and regenerated montane forests. Soil Biology and Biochemistry 34: 711-720.

Joergensen RG, Scheu S. 1999. Depth gradients of microbial and chemical properties in moder soils under beech and spruce. Pedobiologia 43: 134-144.

Keyser P, Kirk TK, Zeikus JG. 1978. Ligninolytic enzyme system of Phanaerochaete chrysosporium: Synthesized in the absence of lignin in response to nitrogen starvation. Journal of Bacteriology 135: 790-797.

Kirschbaum MUF. 1995. The temperature dependence of soil organic matter decomposition, and the effect of global warming on soil organic C storage. Soil Biology and Biochemistry 27: 753-760.

Knorr W, Prentice IC, House JI, Holland EA. 2005. Long-term sensitivity of soil carbon turnover to warming. Nature 433: 298-301.

Koller R, Robin C, Bonkowski M, Ruess L, Scheu S. 2013a. Litter quality as driving factor for plant nutrition via grazing of protozoa on soil microorganisms. FEMS Microbiology Ecology 85: 241-250.

Koller R, Rodriguez A, Robin C, Scheu S, Bonkowski M. 2013b. Protozoa enhance foraging efficiency of arbuscular mycorrhizal fungi for mineral nitrogen from organic matter in soil to the benefit of host plants. New Phytologist 199: 203-211.

Koller R, Scheu S, Bonkowski M, Robin C. 2013c. Protozoa stimulate N uptake and growth of 
arbuscular mycorrhizal plants. Soil Biology and Biochemistry 65: 204-210.

Kottke I, Beck A, Haug I, Setaro S, Jeske V, Suarez JP, Pazzmino L, Preußing M, Nebel M, Oberwinkler F. 2006. Mycorrhizal state and new and special features of mycorrhizae of trees, ericads, orchids, ferns, and liverworts. In: Beck E,, In: Bendix J,, In: Kottke I,, In: Makeschin F,, In: Mosandl R, eds. Gradients in a tropical mountain ecosystem of Ecuador. Springer Verlag, Berlin, Heidelberg, 137-148.

Kottke I, Beck A, Oberwinkler F, Homeier J, Neill D. 2004. Arbuscular endomycorrhizas are dominant in the organic soil of a neotropical montane cloud forest. Journal of Tropical Ecology 20: 125-129.

Kottke I, Haug I. 2004. The significance of mycorrhizal diversity of trees in the tropical mountain forest of southern Ecuador. Lyonia 7: 49-56.

Krashevska V, Bonkowski M, Maraun M, Ruess L, Kandeler E, Scheu S. 2008. Microorganisms as driving factors for the community structure of testate amoebae along an altitudinal transect in tropical mountain rain forests. Soil Biology and Biochemistry 40: 2427-2433.

Krashevska V, Sandmann D, Maraun M, Scheu S. 2012. Consequences of exclusion of precipitation on microorganisms and microbial consumers in montane tropical rainforests. Oecologia 170: 1067-1076.

Leuschner C, Moser G, Bertsch C, Röderstein M, Hertel D. 2007. Large altitudinal increase in tree root/shoot ratio in tropical mountain forests of Ecuador. Basic and Applied Ecology 8: 219230.

Luizao RCC, Bonde TA, Rosswall T. 1992. Seasonal variation of soil microbial biomass-The effects of clearfelling a tropical rainforest and establishment of pasture in the central Amazon. Soil Biology and Biochemistry 24: 805-813.

McNaughton SJ, Oesterheld M, Frank DA, Williams KJ. 1989. Ecosystem-level patterns of primary productivity and herbivory in teresstrial habitats. Nature 341: 142-144.

Moser G, Hertel D, Leuschner C. 2007. Altitudinal change in LAl and stand leaf biomass in tropical montane forests: a transect study in Ecuador and a pan-tropical meta-analysis. Ecosystems 10: 924-935.

Pan Y, Birdsey RA, Fang J, Houghton R, Kauppi PE, Kurz WA, Phillips OL, Shvidenko A, Lewis SL, Canadell JG, et al. 2011. A large and persistent carbon sink in the world's forests. Science 333: 988-994.

Paulsch A, Piechowski D, Müller-Hohenstein K. 2006. Forest vegetation structure along an altitudinal gradient in southern Ecuador. In: Beck E,, In: Bendix J,, In: Kottke I, In: Makeschin $F_{,}$, In: Mosandl R, eds. Gradients in a tropical mountain ecosystem of Ecuador. SpringerVerlag Berlin, 113-121.

Post WM, Emanuel WR, Zinke PJ, Stangenberger AG. 1982. Soil carbon pools and world life zones. Nature 298: 156-159.

Röderstein M, Hertel D, Leuschner C. 2005. Above- and below-ground litter production in three tropical montane forests in southern Ecuador. Journal of Tropical Ecology 21: 483-492.

Scheiner SM, Gurevitch J. 2001. Design and analysis of ecological experiments. Oxford University Press, USA.

Scheu S. 1992. Automated measurement of the respiratory response of soil microcompartments: active microbial biomass in earthworm faeces. Soil Biology and Biochemistry 24: 11131118. 
Scheu S, Parkinson D. 1995. Successional changes in microbial biomass, respiration and nutrient status during litter decomposition in an aspen and pine forest. Biology and Fertility of Soils 19: 327-332.

Todd-Brown KEO, Randerson JT, Hopkins F, Arora V, Hajima T, Jones C, Shevliakova E, Tjiputra J, Volodin E, Wu T, et al. 2014. Changes in soil organic carbon storage predicted by Earth system models during the 21st century. Biogeosciences 11: 2341-2356.

Treseder KK, Balser TC, Bradford MA, Brodie EL, Dubinsky EA, Eviner VT, Hofmockel KS, Lennon JT, Levine UY, MacGregor BJ, et al. 2012. Integrating microbial ecology into ecosystem models: challenges and priorities. Biogeochemistry 109: 7-18.

Wilcke W, Oelmann Y, Schmitt A, Valarezo C, Zech W, Homeier J. 2008. Soil properties and tree growth along an altitudinal transect in Ecuadorian tropical montane forest. Journal of Plant Nutrition and Soil Science 171: 220-230.

Wilcke W, Yasin S, Abramowski U, Valarezo C, Zech W. 2002. Nutrient storage and turnover in organic layers under tropical montane rain forest in Ecuador. European Journal of Soil Science 53: 15-27. 


\section{Appendix}

Table S1: Percentage (of dry weight) of $\mathrm{C}\left(\mathrm{C}_{\mathrm{C}}\right)$ and $\mathrm{N}\left(\mathrm{N}_{\mathrm{c}}\right)$, and $\mathrm{C}$-to- $\mathrm{N}$ ratio in freshly collected leaf and root litter from three different origins (Bomb, ECSF and Caja) along an altitudinal gradient in a tropical montane rainforest.

\begin{tabular}{llccc}
\hline litter type & origin & $\mathrm{C}_{\mathrm{c}}$ & $\mathrm{N}_{\mathbf{c}}$ & $\mathrm{C} / \mathrm{N}$ \\
\hline \multirow{4}{*}{ leaf } & Bomb & 50.1 & 1.35 & 37.0 \\
& ECSF & 50.2 & 0.62 & 81.4 \\
& Caja & 50.6 & 0.64 & 79.5 \\
\hline \multirow{4}{*}{ root } & Bomb & 50.4 & 1.09 & 46.4 \\
& ECSF & 49.8 & 0.76 & 66.0 \\
& Caja & 51.6 & 0.53 & 96.9 \\
\hline
\end{tabular}

Table S2: Repeated measures ANOVA/GLM table of F- and p-values on the effects of altitude (1000, 2000 and $3000 \mathrm{~m}$ ), litter type (roots or leaves), litter origin [Bombuscaro (Bomb), ECSF and Cajanuma (Caja)] and date $(6,12,24,36$ and 48 months) on litter C-to-N ratio. Significant effects are given in bold.

\section{C-to- $N$ ratio}

F-value p-value

\begin{tabular}{lcc}
\hline Between subject effects & & \\
\hline altitude & 89.39 & $<.0001$ \\
origin & 348.71 & $<.0001$ \\
type & 89.28 & $<.0001$ \\
altitude $\times$ origin & 3.45 & 0.0148 \\
altitude $\times$ type & 8.61 & 0.0006 \\
origin $\times$ type & 8.38 & 0.0008 \\
altitude $\times$ origin $\times$ type & 4.70 & 0.0028 \\
\hline Within subject effects & & \\
\hline date & 189.98 & $<.0001$ \\
date $\times$ altitude & 10.09 & $<.0001$ \\
date $\times$ origin & 6.49 & $<.0001$ \\
date $\times$ type & 3.79 & 0.0055 \\
date $\times$ altitude $\times$ origin & 2.09 & 0.0102 \\
date $\times$ altitude $\times$ type & 2.89 & 0.0046 \\
date $\times$ origin $\times$ type & 3.48 & 0.0009 \\
date $\times$ altitude $\times$ origin $\times$ type & 0.56 & 0.9089 \\
\hline & & \\
\hline
\end{tabular}

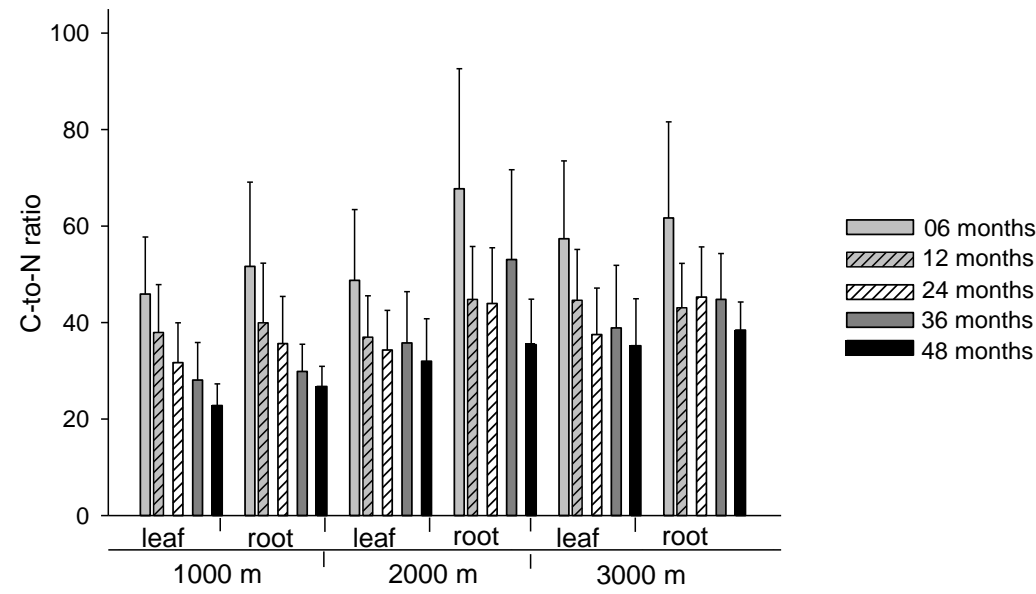

Fig. S1: Variation in C-to- $\mathrm{N}$ ratio in leaf and root litter exposed in tropical montane rainforests at three altitudes (1000, 2000 and $3000 \mathrm{~m}$ ) for 6, 12, 24 ,36 and 48 months (means \pm SD). 
Table S3: Correlation matrix of the amount of $C\left(C_{R}\right)$ and $N\left(N_{R}\right)$, the percentage of $C\left(C_{C}\right)$ and $N\left(N_{c}\right), C$-to- $N$ ratio $(\mathrm{C} / \mathrm{N})$, microbial biomass $\left(\mathrm{C}_{\mathrm{mic}}\right), \mathrm{C}_{\text {mic }}$-to- $\mathrm{C}_{\text {org }}$ ratio $\left(\mathrm{C}_{\mathrm{mic}} / \mathrm{C}_{\mathrm{org}}\right)$ and metabolic oxygen quotient $\left(\mathrm{qO}_{2}\right)$ in decomposing litter material exposed in the field for $6,12,24,36$ and 48 months.

\begin{tabular}{|c|c|c|c|c|c|c|c|c|}
\hline & $C_{R}$ & $N_{R}$ & $C_{c}$ & $\mathbf{N}_{\mathrm{c}}$ & $\mathrm{C} / \mathrm{N}$ & $\mathrm{C}_{\text {mic }}$ & $\mathbf{C}_{\text {mic }} / \mathbf{C}_{\text {org }}$ & $\mathrm{qO}_{2}$ \\
\hline$\overline{\overline{C C_{R}}}$ & $\bar{p} p=--$ & & & & & & & \\
\hline $\mathbf{N}_{\mathrm{R}}$ & $\mathrm{p}=.003$ & $p=---$ & & & & & & \\
\hline $\mathrm{C}_{\mathrm{c}}$ & $\mathrm{p}=0.00$ & $\mathrm{p}=.002$ & $p=--$ & & & & & \\
\hline $\mathbf{N}_{\mathrm{C}}$ & $\mathrm{p}=.000$ & $\mathrm{p}=.123$ & $p=0.00$ & $p=--$ & & & & \\
\hline $\mathrm{C} / \mathrm{N}$ & $p=.000$ & $p=0.00$ & $p=.000$ & $\mathrm{p}=.040$ & $p=---$ & & & \\
\hline $\mathbf{C}_{\text {mic }}$ & $\mathrm{p}=.000$ & $\mathrm{p}=.000$ & $\mathrm{p}=.000$ & $\mathrm{p}=.001$ & $\mathrm{p}=.002$ & $p=---$ & & \\
\hline $\mathbf{C}_{\text {mic }} / \mathbf{C}_{\text {org }}$ & $\mathrm{p}=.382$ & $\mathrm{p}=.000$ & $p=.118$ & $\mathrm{p}=.066$ & $\mathrm{p}=.000$ & $p=0.00$ & $p=---$ & \\
\hline $\mathrm{qO}_{2}$ & $\mathrm{p}=.000$ & $\mathrm{p}=.000$ & $\mathrm{p}=.000$ & $\mathrm{p}=.002$ & $\mathrm{p}=.000$ & $\mathrm{p}=.942$ & $\mathrm{p}=.371$ & $p=---$ \\
\hline
\end{tabular}

Table S4: Correlation matrix of the amount of $C\left(C_{R}\right)$ and $N\left(N_{R}\right)$, the percentage of $C\left(C_{C}\right)$ and $N\left(N_{C}\right), C$-to- $N$ ratio $(\mathrm{C} / \mathrm{N})$, microbial biomass $\left(\mathrm{C}_{\text {mic }}\right), \mathrm{C}_{\text {mic }}$-to- $\mathrm{C}_{\text {org }}$ ratio $\left(\mathrm{C}_{\mathrm{mic}} / \mathrm{C}_{\mathrm{org}}\right)$, metabolic oxygen quotient $\left(\mathrm{qO}_{2}\right)$ and the ergosterol content, measured after 6 months (a), 12 months (b), 24 months (c), 36 months (d) and 48 months (e) in decomposing litter material.

\begin{tabular}{|l|r|r|r|r|r|r|r|r|r|}
\cline { 2 - 11 } & \multicolumn{1}{l|}{$\mathbf{C}_{\mathbf{R}}$} & \multicolumn{1}{l}{$\mathbf{N}_{\mathbf{R}}$} & $\mathbf{C}_{\mathbf{C}}$ & $\mathbf{N}_{\mathbf{C}}$ & $\mathbf{C} / \mathbf{N}$ & $\mathbf{C}_{\text {mic }}$ & $\mathbf{C}_{\text {mic }} / \mathbf{C}_{\text {org }}$ & $\mathbf{q O}_{2}$ & Ergosterol \\
\hline \hline $\mathbf{C}_{\mathbf{R}}$ & $\mathrm{p}=---$ & & & & & & & & \\
\hline $\mathbf{N}_{\mathbf{R}}$ & $\mathrm{p}=.077$ & $\mathrm{p}=---$ & & & & & & & \\
\hline $\mathbf{C}_{\mathbf{C}}$ & $\mathrm{p}=.062$ & $\mathrm{p}=.377$ & $\mathrm{p}=---$ & & & & & & \\
\hline $\mathbf{N}_{\mathbf{C}}$ & $\mathrm{p}=.212$ & $\mathrm{p}=.238$ & $\mathrm{p}=.001$ & $\mathrm{p}=---$ & & & & & \\
\hline $\mathbf{C} / \mathbf{N}$ & $\mathrm{p}=.074$ & $\mathrm{p}=0.00$ & $\mathrm{p}=.435$ & $\mathrm{p}=.039$ & $\mathrm{p}=---$ & & & & \\
\hline $\mathbf{C}_{\text {mic }}$ & $\mathrm{p}=.536$ & $\mathrm{p}=.000$ & $\mathrm{p}=.317$ & $\mathrm{p}=.554$ & $\mathrm{p}=.000$ & $\mathrm{p}=---$ & & & \\
\hline $\mathbf{C}_{\text {mic }} / \mathbf{C}_{\text {org }}$ & $\mathrm{p}=.181$ & $\mathrm{p}=.000$ & $\mathrm{p}=.255$ & $\mathrm{p}=.643$ & $\mathrm{p}=.000$ & $\mathrm{p}=0.00$ & $\mathrm{p}=---$ & & \\
\hline $\mathbf{q} \mathbf{O}_{2}$ & $\mathrm{p}=.259$ & $\mathrm{p}=.075$ & $\mathrm{p}=.003$ & $\mathrm{p}=.292$ & $\mathrm{p}=.097$ & $\mathrm{p}=.046$ & $\mathrm{p}=.037$ & $\mathrm{p}=---$ & \\
\hline Ergosterol & $\mathrm{p}=.021$ & $\mathrm{p}=.840$ & $\mathrm{p}=.189$ & $\mathrm{p}=.249$ & $\mathrm{p}=.686$ & $\mathrm{p}=.000$ & $\mathrm{p}=.000$ & $\mathrm{p}=.134$ & $\mathrm{p}=---$ \\
\hline
\end{tabular}

\begin{tabular}{|c|c|c|c|c|c|c|c|c|c|}
\hline (b) & $C_{R}$ & $\mathbf{N}_{\mathrm{R}}$ & $\mathrm{C}_{\mathrm{c}}$ & $\mathrm{N}_{\mathrm{c}}$ & $\mathrm{C} / \mathrm{N}$ & $\mathrm{C}_{\text {mic }}$ & $\mathbf{C}_{\text {mic }} / \mathbf{C}_{\text {org }}$ & $\mathrm{qO}_{2}$ & Ergosterol \\
\hline$C_{R}$ & $p=---$ & & & & & & & & \\
\hline$N_{R}$ & $p=.734$ & $p=---$ & & & & & & & \\
\hline$C_{c}$ & $\mathrm{p}=.006$ & $\mathrm{p}=.886$ & $p=---$ & & & & & & \\
\hline $\mathbf{N}_{\mathrm{C}}$ & $\mathrm{p}=.292$ & $\mathrm{p}=.285$ & $p=.000$ & $p=---$ & & & & & \\
\hline $\mathrm{C} / \mathrm{N}$ & $\mathrm{p}=.408$ & $p=0.00$ & $\mathrm{p}=.534$ & $\mathrm{p}=.280$ & $p=---$ & & & & \\
\hline $\mathrm{C}_{\text {mic }}$ & $\mathrm{p}=.872$ & $\mathrm{p}=.136$ & $p=.342$ & $\mathrm{p}=.361$ & $\mathrm{p}=.219$ & $p=---$ & & & \\
\hline $\mathbf{C}_{\text {mic }} / \mathbf{C}_{\text {org }}$ & $\mathrm{p}=.235$ & $\mathrm{p}=.162$ & $\mathrm{p}=.634$ & $\mathrm{p}=.465$ & $\mathrm{p}=.183$ & $p=0.00$ & $p=---$ & & \\
\hline $\mathrm{qO}_{2}$ & $\mathrm{p}=.773$ & $\mathrm{p}=.011$ & $\mathrm{p}=.450$ & $\mathrm{p}=.834$ & $\mathrm{p}=.001$ & $\mathrm{p}=.872$ & $\mathrm{p}=.899$ & $p=---$ & \\
\hline Ergosterol & $\mathrm{p}=.853$ & $p=.658$ & $\mathrm{p}=.026$ & $\mathrm{p}=.007$ & $\mathrm{p}=.718$ & $p=.000$ & $p=.001$ & $\mathrm{p}=.098$ & $p=---$ \\
\hline
\end{tabular}

\begin{tabular}{|l|r|r|r|r|r|r|r|r|r|}
\cline { 2 - 11 }$(\mathbf{c})$ & $\mathbf{C}_{\mathbf{R}}$ & $\mathbf{N}_{\mathbf{R}}$ & $\mathbf{C}_{\mathbf{C}}$ & $\mathbf{N}_{\mathbf{C}}$ & $\mathbf{C} / \mathbf{N}$ & $\mathbf{C}_{\text {mic }}$ & $\mathbf{C}_{\text {mic }} / \mathbf{C}_{\text {org }}$ & $\mathbf{q O}_{2}$ & Ergosterol \\
\hline \hline $\mathbf{C}_{\mathbf{R}}$ & $\mathrm{p}=---$ & & & & & & & & \\
\hline $\mathbf{N}_{\mathbf{R}}$ & $\mathrm{p}=.872$ & $\mathrm{p}=---$ & & & & & & & \\
\hline $\mathbf{C}_{\mathbf{c}}$ & $\mathrm{p}=.000$ & $\mathrm{p}=.071$ & $\mathrm{p}=---$ & & & & & & \\
\hline $\mathbf{N}_{\mathbf{C}}$ & $\mathrm{p}=.000$ & $\mathrm{p}=.026$ & $\mathrm{p}=.000$ & $\mathrm{p}=---$ & & & & & \\
\hline $\mathbf{C} / \mathbf{N}$ & $\mathrm{p}=.014$ & $\mathrm{p}=0.00$ & $\mathrm{p}=.001$ & $\mathrm{p}=.002$ & $\mathrm{p}=---$ & & & & \\
\hline $\mathbf{C}_{\text {mic }}$ & $\mathrm{p}=.000$ & $\mathrm{p}=.011$ & $\mathrm{p}=.000$ & $\mathrm{p}=.001$ & $\mathrm{p}=.000$ & $\mathrm{p}=---$ & & & \\
\hline $\mathbf{C}_{\text {mic }} / \mathbf{C}_{\text {org }}$ & $\mathrm{p}=.000$ & $\mathrm{p}=.045$ & $\mathrm{p}=.000$ & $\mathrm{p}=.000$ & $\mathrm{p}=.000$ & $\mathrm{p}=0.00$ & $\mathrm{p}=---$ & & \\
\hline $\mathbf{q} \mathbf{O}_{2}$ & $\mathrm{p}=.000$ & $\mathrm{p}=.202$ & $\mathrm{p}=.014$ & $\mathrm{p}=.229$ & $\mathrm{p}=.006$ & $\mathrm{p}=.000$ & $\mathrm{p}=.000$ & $\mathrm{p}=---$ & \\
\hline Ergosterol & $\mathrm{p}=.155$ & $\mathrm{p}=.865$ & $\mathrm{p}=.845$ & $\mathrm{p}=.374$ & $\mathrm{p}=.378$ & $\mathrm{p}=.003$ & $\mathrm{p}=.002$ & $\mathrm{p}=.031$ & $\mathrm{p}=---$ \\
\hline
\end{tabular}




\begin{tabular}{|c|c|c|c|c|c|c|c|c|}
\hline (d) & $\mathrm{C}_{\mathrm{R}}$ & $\mathbf{N}_{\mathrm{R}}$ & $\mathrm{C}_{\mathrm{c}}$ & $\mathbf{N}_{\mathrm{C}}$ & $\mathbf{C} / \mathbf{N}$ & $\mathrm{C}_{\text {mic }}$ & $\mathbf{C}_{\text {mic }} / \mathbf{C}_{\text {org }}$ & $\mathrm{qO}_{2}$ \\
\hline$C_{R}$ & $p=---$ & & & & & & & \\
\hline$N_{R}$ & $\mathrm{p}=.038$ & $p=---$ & & & & & & \\
\hline $\mathrm{C}_{\mathrm{c}}$ & $\mathrm{p}=.000$ & $\mathrm{p}=.002$ & $p=---$ & & & & & \\
\hline $\mathbf{N}_{\mathrm{C}}$ & $\mathrm{p}=.000$ & $\mathrm{p}=.018$ & $\mathrm{p}=.000$ & $p=---$ & & & & \\
\hline $\mathrm{C} / \mathrm{N}$ & $p=.000$ & $\mathrm{p}=.000$ & $p=.000$ & $\mathrm{p}=.018$ & $p=---$ & & & \\
\hline $\mathrm{C}_{\text {mic }}$ & $\mathrm{p}=.556$ & $\mathrm{p}=.641$ & $\mathrm{p}=.607$ & $\mathrm{p}=.519$ & $\mathrm{p}=.959$ & $p=---$ & & \\
\hline $\mathbf{C}_{\text {mid }} / \mathbf{C}_{\text {org }}$ & $\mathrm{p}=.486$ & $\mathrm{p}=.905$ & $\mathrm{p}=.658$ & $\mathrm{p}=.182$ & $\mathrm{p}=.584$ & $p=0.00$ & $p=---$ & \\
\hline $\mathrm{qO}_{2}$ & $p=.850$ & $\mathrm{p}=.661$ & $\mathrm{p}=.940$ & $\mathrm{p}=.275$ & $p=.208$ & $\mathrm{p}=.014$ & $\mathrm{p}=.014$ & $p=---$ \\
\hline
\end{tabular}

\begin{tabular}{|l|r|r|r|r|r|r|r|r|}
\cline { 2 - 10 }$(\mathrm{e})$ & $\mathbf{C}_{\mathbf{R}}$ & $\mathbf{N}_{\mathbf{R}}$ & $\mathbf{C}_{\mathbf{C}}$ & $\mathbf{N}_{\mathbf{C}}$ & $\mathbf{C} / \mathbf{N}$ & $\mathbf{C}_{\text {mic }}$ & $\mathbf{C}_{\text {mic }} / \mathbf{C}_{\text {org }}$ & $\mathbf{q O}_{2}$ \\
\hline \hline $\mathbf{C}_{\mathbf{R}}$ & $\mathrm{p}=---$ & & & & & & & \\
\hline $\mathbf{N}_{\mathbf{R}}$ & $\mathrm{p}=.657$ & $\mathrm{p}=---$ & & & & & & \\
\hline $\mathbf{C}_{\mathbf{C}}$ & $\mathrm{p}=.000$ & $\mathrm{p}=.003$ & $\mathrm{p}=---$ & & & & & \\
\hline $\mathbf{N}_{\mathbf{C}}$ & $\mathrm{p}=.000$ & $\mathrm{p}=.000$ & $\mathrm{p}=0.00$ & $\mathrm{p}=---$ & & & & \\
\hline $\mathbf{C} / \mathbf{N}$ & $\mathrm{p}=.000$ & $\mathrm{p}=0.00$ & $\mathrm{p}=.000$ & $\mathrm{p}=.000$ & $\mathrm{p}=---$ & & & \\
\hline $\mathbf{C}_{\text {mic }}$ & $\mathrm{p}=.007$ & $\mathrm{p}=.160$ & $\mathrm{p}=.013$ & $\mathrm{p}=.002$ & $\mathrm{p}=.027$ & $\mathrm{p}=---$ & & \\
\hline $\mathbf{C}_{\text {mic }} / \mathbf{C}_{\text {org }}$ & $\mathrm{p}=.000$ & $\mathrm{p}=.214$ & $\mathrm{p}=.001$ & $\mathrm{p}=.000$ & $\mathrm{p}=.007$ & $\mathrm{p}=0.00$ & $\mathrm{p}=---$ & \\
\hline $\mathbf{q O}_{2}$ & $\mathrm{p}=.038$ & $\mathrm{p}=.346$ & $\mathrm{p}=.019$ & $\mathrm{p}=.015$ & $\mathrm{p}=.082$ & $\mathrm{p}=.000$ & $\mathrm{p}=.000$ & $\mathrm{p}=---$ \\
\hline
\end{tabular}




\section{Chapter 3}

Changes in the structure of soil animal communities in decomposing leaf and root litter in tropical montane rainforests: Influence of altitude and litter origin
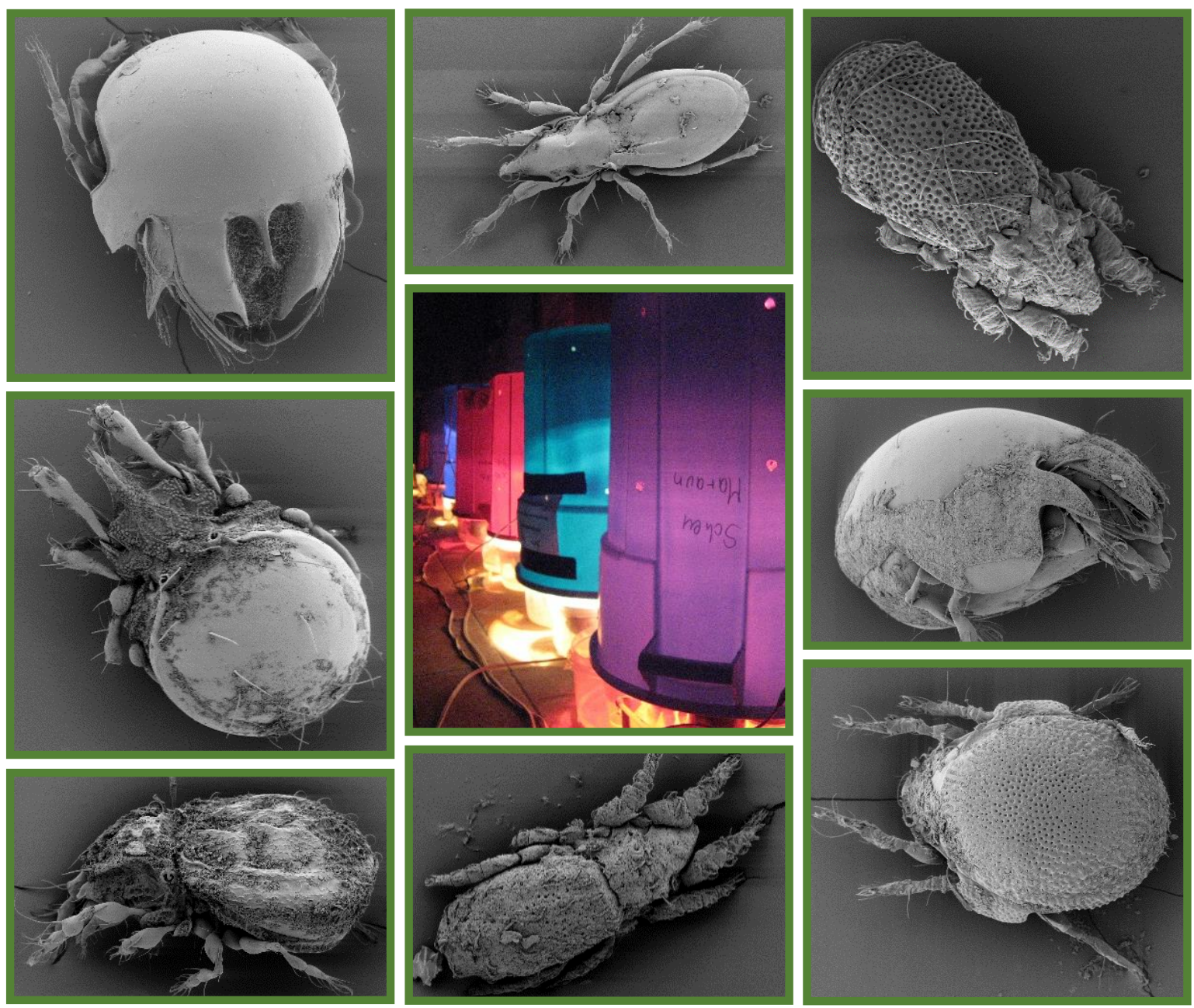

Franca Marian, Dorothee Sandmann, Valentyna Krashevska, Mark Maraun and Stefan Scheu 


\begin{abstract}
Microarthropods impact their habitat by regulating organic matter turnover and nutrient cycling via direct and indirect processing of organic matter entering the soil system as litter fall and root exudates, causing feedback to the aboveground system. The reasons for variation in the structure of soil microarthropod communities still are little understood, but likely they are due to both variations in biotic and abiotic factors such as local climatic conditions and litter quality.

We investigated the effect of altitude, litter origin and litter type on soil microarthropod communities over the course of long term decomposition processes in tropical montane rainforests in southern Ecuador. Leaf litter from three abundant tree species and roots of different diameter were collected from three sites along an altitudinal gradient (1000, 2000, $3000 \mathrm{~m})$. Litter and roots were placed in litterbags at the three altitudes, and after $6,12,24$ and 36 all movable soil fauna was extracted to assess abundance of Collembola and Acarina groups as well as diversity of Oribatida.

Density and diversity of soil microarthropods (i.e. Acarina and Collembola) decreased with increasing altitude and varied with the degree to which the litter was decomposed rather than with litter origin and therefore quality of the litter material. Densities fluctuated over the course of decomposition being generally low after 24 months and again increased after 36 months. Species composition of Oribatida varied strongly between the altitudes, with little species overlap between the altitudes. The percentage of parthenogenetic Oribatida species decreased with increasing altitude.

This suggests that the origin and therefore quality of litter material is of little importance as driving force for the composition of the microarthropod community of tropical montane rainforests. Factors changing with altitude, such as temperature and soil $\mathrm{pH}$, as well as decomposition stage and associated changes the microbial community and interactions with mycorrhizal fungi and litterderived resources are much more important.
\end{abstract}




\section{Introduction}

Soil microarthropods are highly diverse and abundant in soils of virtually any ecosystem and climatic zone (Bardgett, 2005). Their importance for decomposition processes has long been recognized and extensively studied (Scheu, 2002; Cornwell et al., 2008; Kampichler \& Bruckner, 2009; Castanho et al., 2012). Together with other soil fauna groups they impact their habitat by regulating organic matter turnover and nutrient cycling via processing of organic matter that is entering the soil system via litter fall and root exudates (Bardgett, 2005). These processes cause feedbacks to the aboveground system, resulting in enhanced soil fertility and increased plant performance (Scheu, 2001; Wardle et al., 2004; van der Putten et al., 2009). Besides the major regulatory forces, i.e. climatic conditions, litter quality and parent rock (Kirschbaum, 1995; Coûteaux et al., 2002; Davidson \& Janssens, 2006; Berg, 2014), interactions between organisms are considered to be an important factor regulating decomposition processes (Seastedt, 1984; Heneghan et al., 1999; Castanho et al., 2012). Understanding decomposition processes in detail is of significant importance since over $90 \%$ of the carbon fixed by plants is entering the soil system via litter fall and root exudates (McNaughton et al., 1989; Bardgett et al., 2005). The effect of soil microarthropods on decomposition processes may be direct by shredding litter material, but also indirect via trophic interactions with the fungal and bacterial community (Moore et al., 1988; Maraun et al., 1998; Pollierer et al., 2012; Zieger et al., 2015). Collembola and Acari, the two most abundant and diverse microarthropod taxa in soil, interact closely with bacteria and fungi. Both comprise a wide spectrum of species of different trophic levels including primary decomposers, secondary decomposers and in part also predators (Scheu, 2002; Schneider et al., 2004; Chahartaghi et al., 2005).

Although soil organisms are present in virtually any soil (Bardgett, 2005), their abundance and diversity varies between ecosystems as well as within few centimetres of soil (Ettema \& Wardle, 2002). The reasons for the high spatial heterogeneity in the structure of soil microarthropod communities still are little understood, but likely it is due to both variations in biotic and abiotic factors such as local climatic conditions and litter quality (Coûteaux et al., 1995; Wardle et al., 2006; Berg \& McClaugherty, 2008). Leaf and root litter form the two most important types of plant litter differing markedly in quality (Berg \& McClaugherty, 2008), surprisingly, however, decomposition of leaf and root litter of plant species in one ecosystem have rarely been studied in combination (Berg \& McClaugherty, 2008; Cusack et al., 2009). In particular, little is known on variations in the structure of microarthropod communities in leaf as compared to root litter.

High functional diversity of soil fauna is related to increased decomposition processes in a wide range of terrestrial as well as aquatic ecosystems (Handa et al., 2014). Especially in tropical rainforests high diversity as well as high abundance of soil microarthropods are related to high decomposition rates (Heneghan et al., 1999; Castanho et al., 2012). However, most studies 
assessing soil microarthropods in tropical regions have been carried out in lowland rainforests (Heneghan et al., 1999; Palacios-Vargas et al., 2007; Castanho et al., 2012), where climatic conditions are favourable and the diversity of microarthropods is high. In particular, there is a lack of knowledge on interrelationships between litter decomposition and the structure of soil microarthropod communities in tropical montane rainforests.

Tropical montane rainforests of the Andes are one of the most species rich and diverse ecosystems on earth with around 20,000 endemic plant and 1567 endemic vertebrate species (Myers et al., 2000). Diversity of arthropods in this ecosystem also is exceptionally high, but studies assessing this diversity so far focused on the above ground system (Myers et al., 2000; Mittelbach et al., 2001). Maraun et al. (2007) found Oribatida diversity of montane rainforests of the tropical Andes to resemble that of temperate forests, indicating that belowground taxa do not follow the aboveground pattern of markedly increased diversity in the tropics. Unfortunately, the factors driving soil microarthropod abundance and diversity of tropical rainforests remain poorly understood hampering understanding of global diversity gradients, but also variations between different tropical rainforest ecosystems.

Changes in biodiversity and abundance of aboveground taxa have been widely studied along altitudinal gradients (Richardson et al., 2005; Sanders et al., 2009; Sundqvist et al., 2013; Willig \& Presley, 2015), while only few studies investigated changes in the below ground system. In the tropical Andes of southern Ecuador climatic conditions, plant community composition as well as soil structure and pH change with altitude (Leuschner et al., 2007; Moser et al., 2007; Homeier et al., 2010). A prominent change which presumably is of significant importance for soil animal communities is the thickness of organic layers which increases with increasing altitude (Röderstein et al., 2005; Leuschner et al., 2007; Wilcke et al., 2008). Generally, compared to tropical lowland or temperate forests, decomposition processes in tropical montane forests are slow especially at higher altitudes (F. Marian, unpublished data, Chapter 2; Post et al., 1982; Heneghan et al., 1999; Butenschoen et al., 2014). Parallel to the increase in the thickness of organic layers, Illig et al. (2010) found the abundance and diversity of Oribatida to decrease along an altitudinal gradient in the tropical Andes, but the factors responsible for these changes are little understood.

Most studies assessing interrelationships between litter decomposition and microarthropod communities focused on early stages of decomposition and lasted for only one to two years (Heneghan et al., 1999; Scheu, 2002; Kampichler \& Bruckner, 2009; Castanho et al., 2012), whereas changes in the structure of microarthropod communities at later stages of decomposition received little attention. In Andean tropical montane rainforests less than $50 \%$ of the litter material decomposes within the first year and in the later phases litter decomposition slows down strongly in particular at higher altitude (F. Marian, unpublished data, Chapter 2; Butenschoen et al., 2014). 
Whether these changes are paralleled by changes in the abundance and diversity of soil microarthropods as major drivers of decomposition processes, however, remains unknown.

A commonly used method to asses not only decomposition rates but also linkages between abundance and diversity of soil animals and litter decomposition in the field are litterbags (Kampichler \& Bruckner, 2009). In the present study, we used litterbags filled with litter material from three different altitudes to investigate the influence of altitude, i.e. site-specific conditions, and litter origin, i.e. litter quality, on the colonisation of leaf and root litter by microarthropods over the course of three years in an Andean tropical montane rainforest of southern Ecuador. Acari and Collembola as major microarthropod taxa were investigated, with special focus on Oribatida, one of the most abundant and species rich soil Acari groups. Parallel, litter decomposition and microbial activity in the litterbags was assessed (F. Marian, unpublished data, Chapter 2) and the results are used in the present study to relate changes in microarthropod density and community composition to litter decomposition.

The study aims at disentangling whether the abundance of major microarthropod groups, such as Collembola and Acari, and the diversity of Oribatida, along altitudinal gradients is driven by the quality of the litter material, i.e. the origin of the litter from rainforests at different altitudes, or other site specific conditions (biotic and abiotic), and if their abundance differs between leaf and root litter. We hypothesized that the abundance of the Collembola and Acari as well as Oribatida diversity decreases along (1) the altitudinal gradient and (2) from leaf to root litter. We further hypothesized that abundance and diversity vary (3) with the initial litter quality and (4) with the degree to which the litter material is decomposed.

\section{Material and methods}

\section{Study site}

The study area, with three study sites along an altitudinal gradient at 1000, 2000 and $3000 \mathrm{~m}$ a.s.l., is located in southern Ecuador on the eastern slope of the Andes. All study sites are in the northern part of the Podocarpus National Park facing northeast to northwest. The slopes are moderately steep with $26^{\circ}-31^{\circ}$ (Moser et al., 2007) and covered with mostly undisturbed montane rainforest (Homeier et al., 2002). The site at $1000 \mathrm{~m}$ (Bombuscaro, S04 $06^{\prime} 54^{\prime \prime}, \mathrm{W} 78^{\circ} 58^{\prime} 02^{\prime \prime}$ ) is located south of the city Zamora in the valley of the Rio Bombuscaro. The site at $2000 \mathrm{~m}$ (San Francisco, $\left.\mathrm{S}^{\circ} 58^{\prime} 18^{\prime \prime}, \mathrm{W} 79^{\circ} 4^{\prime} 45^{\prime \prime}\right)$ is part of a private reserve, the Reserva Biologica San Francisco, which includes an area of 9 ha on the flank of the valley of the Rio San Francisco on the northern border of the Podocarpus National Park. The third site at 3000 m (Cajanuma, S04 ${ }^{\circ} 06^{\prime} 711^{\prime \prime}$, W79 $19^{\circ} 58^{\prime \prime}$ ) is located south of the city Loja at the north-west gate of the Podocarpus National Park. With 8-10 humid months per year the region has a semi humid climate. Mean annual rainfall increases from 
2230 and $1950 \mathrm{~mm}$ at 1000 and $2000 \mathrm{~m}$, respectively, to $4500 \mathrm{~mm}$ at $3000 \mathrm{~m}$ (Moser et al., 2007), while the mean annual air temperature gradually decreases with increasing altitude from 19.4 to 15.7 to $9.4^{\circ} \mathrm{C}$ at 1000,2000 and $3000 \mathrm{~m}$, respectively. Soil pH also gradually decreases with increasing altitude from 3.94 to 3.52 to 2.86 at 1000, 2000 and 3000 m, respectively (Moser et al., 2007). With increasing altitude the mean soil moisture in the organic layer increases to 45.3 vol.\% at $3000 \mathrm{~m}$ as compared to 9.9 and 11.6 vol.\% at 1000 and $2000 \mathrm{~m}$, respectively (Leuschner et al., 2007). Biotic conditions also change along the altitudinal gradient. Mean tree height decreases from 15.6 to 10.1 to $5.2 \mathrm{~m}$ at 1000, 2000 and $3000 \mathrm{~m}$, respectively, while thickness of organic layers as well as fine root biomass increases from $48 \mathrm{~mm}$ and $2.7 \mathrm{tha}^{-1}$ to $305 \mathrm{~mm}$ and $6.2 \mathrm{t} \mathrm{ha} \mathrm{a}^{-1}$ to $435 \mathrm{~mm}$ and $10.8 \mathrm{t} \mathrm{ha}^{-1}$ at the respective sites (Leuschner et al., 2007; Moser et al., 2007; Graefe et al., 2008). Soil types at 1000, 2000 and 3000 m are predominantly Alumic Acrisols, Gley Cambisols and Podzols, respectively (Moser et al., 2007). At $1000 \mathrm{~m}$ the litter layer overlays the mineral soil (Ah horizon), i.e. F and $\mathrm{H}$ layers are lacking; in contrast, at 2000 and $3000 \mathrm{~m}$ the leaf litter overlays organic layers comprising predominantly of $\mathrm{F}$ material.

\section{Experimental setup}

Litterbags ( $4 \mathrm{~mm}$ mesh) were used to investigate the influence of altitude and litter origin on soil microarthropod community composition and colonization of leaf and root litter by microarthropods. At each of the three study sites ('origins') freshly fallen leaf litter of the three most abundant tree families (i.e., Puteria sp., Cavendishia zamorensis and Mollinedia sp. from 1000 m; Graffenrieda emarginata, Clusia spp. and Cavendishia zamorensis from 2000 m; Clusia spp., Graffenieda emarginata and Hediosmum sp. from $3000 \mathrm{~m}$ ) was collected from the forest floor within the study sites. Roots were collected by digging up the upper 20 to $30 \mathrm{~cm}$ of organic material and soil and removing all roots from this layer by hand. To clear from adhering soil, the roots were washed by gentle rinsing with tap water in the laboratory. Roots were separated into three size classes, small ( $<2 \mathrm{~mm}$ diameter), medium (2 - $5 \mathrm{~mm}$ diameter) and large ( $>5 \mathrm{~mm}$ diameter). Both leaves and roots were dried at $60^{\circ} \mathrm{C}$ for four days. To simulate natural conditions and at the same time standardize conditions as far as possible, litterbags where filled with $10 \mathrm{~g}$ of leaves/roots by mixing leaves of the three plant families, respectively, root size classes, according to the relative abundance of leaf families/root size classes at the three altitudes (see Chapter 2), resulting in six litter mixtures, one with leaf and one with root litter from each of the three origins.

The litterbags, filled with the six different litter mixtures, were placed at the study sites on each of the three altitudes. The leaf litterbags were placed on top of the litter layer, whereas the root litterbags were placed between the fresh litter layer and the soil $(1000 \mathrm{~m})$, respectively fermentation layer (2000 and $3000 \mathrm{~m}$ ), where fine root density is at a maximum. At each of the 
three study sites three blocks were established with a minimum distance between the blocks of $20 \mathrm{~m}$. In each block four replicates of each treatment were placed with one replicate from each block being retrieved at each of four dates, i.e. after 6, 12, 24 and 36 months, resulting in 216 litterbags in total.

\section{Species extraction and determination}

Mobile soil fauna was extracted from one half of the litter material via heat using modified Kempson extractors (Kempson et al., 1963). The extraction was performed directly after collection and transfer of the litterbags to the laboratory. Extracted animals were stored in $70 \%$ ethanol. Most animal groups were determined to order, suborder or cohort level using Schaefer (2010) except for Oribatida. Collembola were separated into five morphologically defined groups resembling the Collembola families Entomobryidae, Isotomidae, Sminthuridae, Hypogastruridae/Neanuridae (Hypogast/Neanu) and the genus Megalothorax and were named accordingly. Individuals of Oribatida were determined to species level if possible. Due to the lack of appropriate keys for determination this was not possible for Brachychthoniidae, Galumnidae, Mesoplophoridae, Phthiracaridae and Euphthiracaridae. For the determination of other Oribatida taxa the keys of Balogh and Balogh $(1988,2002)$ and Weigmann $(2006)$ were used. Species names of Oribatida follow Subias (2015) and were classified also into families according to Krantz (2009). In total 19,077 individuals were determined, with Collembola (4352 individuals) and Acari (11,275 individuals) being most abundant. Within Acari the dominant group of Oribatida made up 7202 individuals of which 5862 individuals were determined to species level.

\section{Calculations and statistical analysis}

To correct for the different amount of litter material left in litterbags the abundance of animals was calculated per $10 \mathrm{~g}$ litter dry weight (DW), the initial amount of litter in the litterbags. The abundance of the total mobile soil fauna, Collembola, Prostigmata, Mesostigmata and Oribatida as well as the abundance of the Collembola morphogroups and Oribatida families Brachychthoniidae, Galumnidae, Mesoplophoridae, Phthiracaridae and Euphthiracaridae and species diversity of the remaining Oribatida per litterbag were analysed by repeatedly measured four-factor randomized complete block multivariate analyses of variance (MANOVA) with time $(6,12,24$ and 36 months) as repeated factor and block (1, 2 and 3$)$ being nested in altitude. Fixed factors were altitude (1000, 2000 and 3000 m a.s.I.), litter origin [Bombuscaro (Bomb), ECSF and Cajanuma (Caja)] and litter type (leaf and root litter). Except for the diversity of Oribatida block was excluded from the analyses as there were no significant block effects. Protected repeated measures analyses of variance (ANOVA; type III sum of squares) with the same factors as stated above were carried out using general linear 
models (GLM; type III sum of squares), providing between and within subject effects and significant variations between the dates. Single ANOVAs for each sampling date were performed to identify differences between dates. Tukey's HSD test $(\alpha<0.05)$ was used to identify significant differences between means. Statistical analyses were performed using SAS (Statistical Analysis System, Version 9.3; SAS Institute Inc., Cary, NC, USA).

Oribatida species in leaf and root litter present in three or more samples were analysed by detrended correspondence analysis (DCA) including altitude and sampling date as passive variables not affecting the ordination using CANOCO (Lepš \& Šmilauer, 2003). Origin of the litter material was not included as earlier analyses indicated that it was of minor importance.

Before the analyses data were inspected for homogeneity of variance and normal distribution and log-transformed if appropriate. Means presented in the results and figures are based on nontransformed data.

\section{Results}

\section{Abundance of soil mesofauna}

The abundance of soil mesofauna decreased with increasing altitude and varied significantly with time and litter type (Table 1). In each of the treatments the abundance increased from 6 to 12 , decreased from 12 to 24 and again increased from 24 to 36 months.

Table 1: Repeated measures GLM table of F- and p-values on the effect of altitude (1000, 2000 and $3000 \mathrm{~m})$, litter type (type: roots or leaves), litter origin [origin: Bombuscaro (Bomb), ECSF and Cajanuma (Caja)] and date $(6,12,24$ and 36 months) on the abundance of soil mesofauna, the decomposer groups Oribatida and Collembola, as well as the predator groups Prostigmata and Mesostigmata. Significant effects are given in bold.

\begin{tabular}{|c|c|c|c|c|c|c|c|c|c|c|}
\hline & \multicolumn{2}{|c|}{ Soil invertebrates } & \multicolumn{2}{|c|}{ Oribatida } & \multicolumn{2}{|c|}{ Collembola } & \multicolumn{2}{|c|}{ Prostigmata } & \multicolumn{2}{|c|}{ Mesostigmata } \\
\hline & F-values & p-values & F-values & p-values & F-values & p-values & F-values & p-values & F-values & p-values \\
\hline \multicolumn{11}{|l|}{ Between subject effects } \\
\hline altitude & 68.67 & $<.0001$ & 65.01 & $<.0001$ & 84.52 & $<.0001$ & 7.48 & 0.0019 & 160.34 & $<.0001$ \\
\hline origin & 0.15 & 0.8587 & 0.76 & 0.4747 & 3.17 & 0.0549 & 1.41 & 0.2564 & 0.42 & 0.661 \\
\hline altitude $\times$ origin & 0.48 & 0.7505 & 1.01 & 0.4173 & 1.14 & 0.354 & 2.16 & 0.093 & 1.91 & 0.1297 \\
\hline type & 0.94 & 0.338 & 19.23 & $<.0001$ & 20.63 & $<.0001$ & 0.27 & 0.6067 & 2.58 & 0.1168 \\
\hline altitude $\times$ type & 2.48 & 0.098 & 5.56 & 0.0079 & 6.24 & 0.005 & 2.18 & 0.1272 & 0.44 & 0.6461 \\
\hline origin $\times$ type & 0.93 & 0.4043 & 0.06 & 0.9465 & 2.51 & 0.0971 & 0.53 & 0.5943 & 0.83 & 0.4459 \\
\hline altitude $\times$ origin $\times$ type & 0.8 & 0.5334 & 0.96 & 0.4414 & 0.19 & 0.9439 & 1.81 & 0.1488 & 0.95 & 0.4454 \\
\hline \multicolumn{11}{|l|}{ Within subject effects } \\
\hline date & 26.42 & $<.0001$ & 81.06 & $<.0001$ & 32.86 & $<.0001$ & 20.72 & $<.0001$ & 46.35 & $<.0001$ \\
\hline date $\times$ altitude & 2.99 & 0.0098 & 1.77 & 0.1122 & 2.08 & 0.0617 & 2.89 & 0.0118 & 7.71 & $<.0001$ \\
\hline date $\times$ origin & 1.67 & 0.1363 & 1.17 & 0.3295 & 0.5 & 0.8073 & 0.49 & 0.8131 & 2.21 & 0.047 \\
\hline date $\times$ altitude $\times$ origin & 1.39 & 0.1805 & 1.18 & 0.3101 & 0.53 & 0.8904 & 1.6 & 0.1022 & 1.02 & 0.4395 \\
\hline date $\times$ type & 1.86 & 0.14 & 2.73 & 0.0477 & 10.96 & $<.0001$ & 0.8 & 0.4944 & 1.52 & 0.2141 \\
\hline date $\times$ altitude $\times$ type & 2.97 & 0.01 & 1.5 & 0.1866 & 4.54 & 0.0004 & 0.66 & 0.6793 & 0.76 & 0.6057 \\
\hline date $\times$ origin $\times$ type & 2.4 & 0.0324 & 3.7 & 0.0022 & 1.15 & 0.3393 & 0.72 & 0.6356 & 2.14 & 0.0549 \\
\hline date $\times$ altitude $\times$ origin $\times$ type & 1.1 & 0.3646 & 1.8 & 0.0562 & 1.17 & 0.3165 & 1.2 & 0.2906 & 0.76 & 0.6888 \\
\hline
\end{tabular}


On average, the abundance was higher in leaf than in root litter, with the exception at $3000 \mathrm{~m}$ after 6 months where root litter contained $107 \%$ more individuals than leaf litter. In each of the treatments the abundance was highest after 36 months, ranging from $1348.0 \pm 799.8$ in leaf litter at $1000 \mathrm{~m}$ to $183.3 \pm 127.8$ ind. $10 \mathrm{~g}^{-1} \mathrm{DW}$ in root litter at $3000 \mathrm{~m}$. After 6 months the abundance was lowest in most treatments, varying between $332.0 \pm 224.9$ and $68.0 \pm 45.7$ ind. $10 \mathrm{~g}^{-1}$ DW in leaf litter at 1000 and leaf litter at $3000 \mathrm{~m}$, respectively. Only in root litter at $3000 \mathrm{~m}$ the abundance was lowest after 24 months $\left(95.0 \pm 56.0\right.$ ind. $10 \mathrm{~g}^{-1} \mathrm{DW}$ compared to $140.9 \pm 45.7 \mathrm{ind} .10 \mathrm{~g}^{-1} \mathrm{DW}$ after 6 months). Origin of the litter material also affected the abundance of soil mesofauna, but the effect varied strongly with time and litter type (Table 1). The previously described pattern of alternating increase and decrease between the sampling dates was present in both leaf and root litter from all origins, with the exception of root litter from ECSF where the abundance did not decrease from 12 to 24 months. After 6 months abundances in litter material from Bomb were higher compared to litter from ECSF and Caja. Leaf litter from ECSF and Caja contained similar abundances, while root litter from ECSF contained higher abundances. After 12 and 24 months leaf litter from Caja contained higher abundances than both leaf litter from ECSF and Bomb, while in root litter the highest abundances after 12 months were still present in litter from Bomb and after 24 months in litter from ECSF. After 36 months abundances in leaf litter were lowest in material from Caja while in root litter both material from ECSF and Caja contained low abundances.

\section{Abundance of Oribatida}

Oribatida were the most abundant microarthropods comprising $37.8 \%$ of the total mesofauna; the overall mean density was $170.4 \pm 212.8$ ind. $10 \mathrm{~g}^{-1} \mathrm{DW}$. Time was the most important factor affecting the abundance of Oribatida followed by altitude (Table 1). However, the effect of time varied with the type and origin of the litter material (Table 1, Fig. 1). Generally, changes in Oribatida abundance were similar to those of total soil fauna. Abundance was higher in leaf as compared to root litter, especially from 12 months onward. In most samples the abundance of Oribatida increased from 6 to 12 months, decreased from 12 to 24 months and again increased from 24 to 36 months. Only in leaf litter from Caja and root litter from ECSF the abundance of Oribatida remained constant between 24 and 36 months, while the increase between these two sampling dates was most prominent in root litter from Caja. With increasing altitude the abundance of Oribatida decreased, but the decline varied with the type of litter material (Table 1). At $1000 \mathrm{~m}$ the abundance in the two litter types did not differ significantly, while at 2000 and $3000 \mathrm{~m}$ the abundance in root litter was $50.5 \pm 0.1 \%$ lower than in leaf litter. Therefore, the decrease in abundance from 1000 to $2000 \mathrm{~m}$ was stronger in root as compared to leaf litter. 


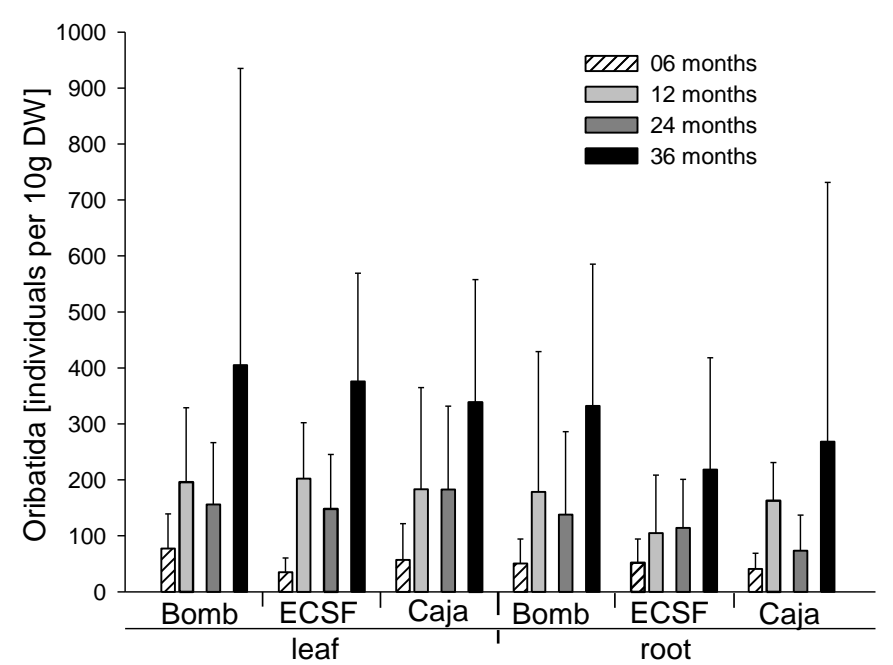

Fig. 1: Abundance of Oribatida in litterbags with leaf and root litter from three origins [Bombuscaro (Bomb), ECSF and Cajanuma (Caja)] exposed in tropical montane rainforests for 6, 12, 24 and 36 months (means $\pm S D$ ).

The five Oribatida families that were not identified to species level comprised $18.6 \%$ of the total number of Oribatida. The response of these five families to the treatments fell into three groups: (1) Mesoplophoridae were the least responsive group, being only influenced by the altitude. Their abundance was generally low, with densities below a mean of 2 ind. $10 \mathrm{~g}^{-1} \mathrm{DW}$ and decreased with increasing altitude (Appendix Table S1). (2) Galumnidae and Phthiracaridae showed an intermediately strong response. Altitude and time had the strongest effects on Galumnidae, again decreasing with increasing altitude and showing the same abundance pattern over time as the higher taxonomic levels (Appendix Table S1). The effect of date varied further with origin and litter type (Appendix Fig. S1). Abundance of Phthiracaridae in the two litter types varied between the three altitudes (Appendix Table S1), with abundance of Phthiracaridae in leaf litter exceeding that of root litter at 2000 and $3000 \mathrm{~m}$ while it was the other way round at $1000 \mathrm{~m}$. Abundance of Phthiracaridae in the two litter types also varied with altitude and the pattern differed from the one at higher taxonomic levels. In leaf litter abundance increased by $333 \%$ from 6 to 12 months and remained constant afterwards at $10.3 \pm 0.3$ ind. $10 \mathrm{~g}^{-1} \mathrm{DW}$, while in root litter the abundance increased from 6 to 12 months by only $88.1 \%$ followed by a decrease from 12 to 24 months by $23.7 \%$. From 24 to 36 months the abundance remained constant at a mean of $5.5 \pm 0.1$ ind. $10 \mathrm{~g}^{-1} \mathrm{DW}$. (3) Brachychthoniidae and Euphthiracaridae were most responsive to the treatments (Appendix Table S1). Brachychthoniidae abundance differed strongest between the altitudes, increasing from 1000 to $2000 \mathrm{~m}$ and strongly decreasing from 2000 to $3000 \mathrm{~m}$. This effect varied with time and litter type (Appendix Table S1; Fig. S2) with the highest abundance being present after 36 months at all altitudes and in both litter types. Euphthiracaridae also differed strongest between the three altitudes, decreasing from 1000 to $2000 \mathrm{~m}$ and further to $3000 \mathrm{~m}$. 
However, the decrease varied with the sampling dates and litter type as well as with date and litter origin (Appendix Table S1; Fig. S3).

\section{Abundance of Collembola}

Collembola comprised $22.8 \%$ of the total mesofauna; the overall mean density was $89.9 \pm 95.7$ ind. $10 \mathrm{~g}^{-1} \mathrm{DW}$. Temporal variations in Collembola abundance mainly resembled that of total mesofauna and Oribatida (Fig. 1 and 2). Altitude was the most important factor influencing Collembola abundance, which decreased with increasing altitude, however, the effect of altitude varied with time and litter type (Table 1, Fig. 2). The abundance of Collembola increased from 6 to 12 months at all altitudes and in both litter types except root litter at $3000 \mathrm{~m}$. At $1000 \mathrm{~m}$ the increase was similar in leaf and root litter with $183.3 \pm 2.5 \%$, while at 2000 and $3000 \mathrm{~m}$ the increase in leaf litter was much stronger as compared to root litter, where abundance at $3000 \mathrm{~m}$ even decreased from 6 to 12 months. From 12 to 24 months the abundance of Collembola in leaf and root litter decreased at each altitude by $65.2 \pm 11.8 \%$, while from 24 to 36 months it increased again, reaching a maximum after 36 months in each of the treatments except root litter at $3000 \mathrm{~m}$.

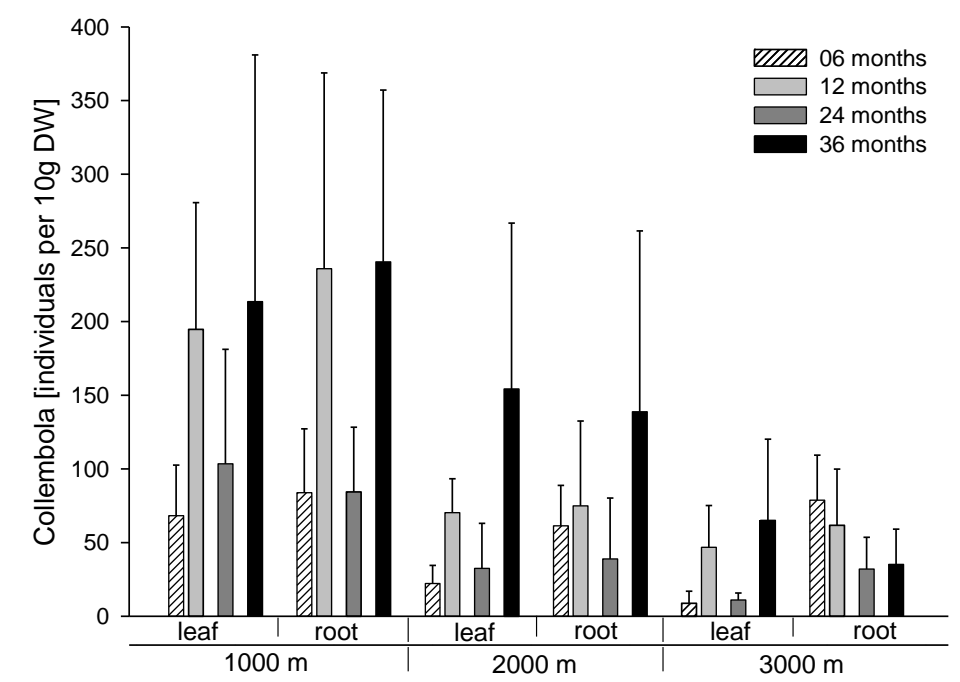

Fig. 2: Abundance of Collembola in litterbags with leaf and root litter placed at three altitudes (1000, 2000 and $3000 \mathrm{~m}$ ) exposed in tropical montane rainforests for 6, 12, 24 and 36 months (means \pm SD).

The pattern in total Collembola resembled the response of the most abundant Collembola morphogroup, i.e. Isotomidae. Altitude had the strongest effect on total Collembola as well as Isotomidae, closely followed by sampling date, while the origin of the litter material had no effect (Appendix Table S2). Isotomidae abundance was highest at $1000 \mathrm{~m}$ and after 12 and 36 months (Appendix Fig. S4d). In root litter the abundance of Isotomidae was higher compared to leaf litter (Appendix Fig. S4c). For most other morphogroups the abundance also declined with increasing altitude, only Sminthuridae reached highest abundance at $2000 \mathrm{~m}$ followed by $3000 \mathrm{~m}$ and $1000 \mathrm{~m}$ 
(Appendix Fig. S6). Sampling date also affected all morphogroups, but only for Isotomidae the pattern resembled that of total Collembola (Appendix Table S2; Fig. S4c and d). The abundance of Hypogastruridae/Neanuridae increased from 6 to 12 and again slightly from 24 to 36 months, between 12 and 24 months it remained constant (Appendix Table S2; Fig. S4e and f). The other three groups Sminthuridae, Entomobryidae and Megalothorax, were most abundant after 6 and 12 months and thereafter their abundance declined (Appendix Table S2; Fig. S6, S4a and b and S5). These major patterns varied to some degree with other factors but the effects of these factors were minor (Appendix Fig. S4-6).

\section{Abundance of Mesostigmata and Prostigmata}

Mesostigmata comprised $13.9 \%$ of the total mesofauna; the overall mean density was $64.1 \pm 89.3$ ind. $10 \mathrm{~g}^{-1}$ DW. Similar to Oribatida and Collembola, the abundance of Mesostigmata also varied with time and altitude (Table 1, Appendix Fig. S7a), with the abundance generally being highest at $1000 \mathrm{~m}$. After 6 months the abundance at $1000 \mathrm{~m}$ was still low with $39.9 \pm 26.2$ ind. $10 \mathrm{~g}^{-1} \mathrm{DW}$, but increased from 6 to 12 months by $364 \%$. From 12 to 24 months the abundance decreased by $27.2 \%$, in the following year it increased again by $62.3 \%$, reaching $219 \pm 130$ ind. $10 \mathrm{~g}^{-1} \mathrm{DW}$ after 36 months. At $2000 \mathrm{~m}$ the abundance of Mesostigmata was below 15 ind. $10 \mathrm{~g}^{-1}$ DW after both 6 and 24 months. From 6 to 12 months it increased to $41.7 \pm 26.5$ ind. $10 \mathrm{~g}^{-1} \mathrm{DW}$ and, following a decrease after 24 months, it increased again after 36 months reaching $85.8 \pm 65.9$ ind. $10 \mathrm{~g}^{-1} \mathrm{DW}$. At $3000 \mathrm{~m}$ the abundance was lowest; generally, it did not exceed $17.0 \pm 13.2$ ind. $10 \mathrm{~g}^{-1} \mathrm{DW}$, the maximum density after 36 months (Appendix Fig. S7a). The abundance of Mesostigmata also varied with the origin of the litter material but this depended on the sampling date (Table 1, Appendix Fig. 7b). Litter material from each of the three origins showed the common pattern with the abundance being lowest after 6 months and highest after 36 months. Generally, the abundances of Mesostigmata in litter from Bomb exceeded that in litter from the other two origins.

Prostigmata comprised $6 \%$ of the total mesofauna; the overall mean density was $23.5 \pm 33.1$ ind. $10 \mathrm{~g}^{-1}$ DW. Similar to Oribatida, Collembola and Mesostigmata, the abundance of Prostigmata varied significantly with time and altitude (Table 1, Appendix Fig. S7c). At each altitude the abundance of Prostigmata was lowest after 6 months, with only $12.7 \pm 10.9,5.1 \pm 6.5$ and $10.9 \pm$ 10.5 ind. $10 \mathrm{~g}^{-1} \mathrm{DW}$ at 1000, 2000 and $3000 \mathrm{~m}$, respectively. The abundance then increased from 6 to 12 months by $122.2,130.3$ and $84.3 \%$ at 1000,2000 and 3000 m, respectively, and thereafter remained at a constant level between 12 and 24 months. At 1000 and $2000 \mathrm{~m}$ the abundance of Prostigmata increased strongly from 24 to 36 months reaching 65.1 and 45.3 ind. $10 \mathrm{~g}^{-1}$ DW, respectively. While at $3000 \mathrm{~m}$ the abundance of Prostigmata stayed almost constant between 12 and 36 months at a mean value of $22.0 \pm 1.8$ ind. $10 \mathrm{~g}^{-1} \mathrm{DW}$. 


\section{Diversity of Oribatida}

A total of 189 species of Oribatida were found at the three study sites. Oribatida diversity varied significantly with time $\left(F_{3 / 90}=27.04 ; p=<0.0001\right)$ and altitude $\left(F_{2 / 30}=93.85 ; p=<0.0001\right)$, but the effect of altitude also varied with litter type $\left(F_{2 / 30}=6.07 ; p=0.006\right)$. Overall, species numbers decreased with increasing altitude, with the decrease being stronger in leaf than in root litter. The effect of time also varied between the altitudes $\left(F_{6 / 90}=2.26 ; p=0.044\right)$. At each of the altitudes the mean species number increased from 6 to 12 months from $10.7 \pm 5.4$ to $16.0 \pm 5.8,4.6 \pm 2.8$ to $9.0 \pm 3.2$ and $2.8 \pm 1.6$ to $6.4 \pm 2.3$ at 1000,2000 and $3000 \mathrm{~m}$, respectively. Thereafter, it uniformly decreased from 12 to 24 months at each altitude, but this was less pronounced at $1000 \mathrm{~m}$ with a decrease by only $18.8 \%$ as compared to a decrease by 51.2 and $38.6 \%$ at 2000 and 3000 m, respectively. From 24 to 36 months species numbers increased again to a level close to the one after 12 months. The variation of species numbers with time also varied with litter origin and litter type $\left(F_{6 / 90}=2.92 ; p=0.012 ; F i g .3\right)$. After 6 months species numbers were lowest in leaf litter from ECSF, but increased strongest in this treatment from 6 to 12 months by $228 \%$. The decrease in species numbers from 12 to 24 months also varied between the treatments with the strongest decrease in root litter from Caja with $51.0 \%$ compared to only $14.7 \%$ in root litter from ECSF. The increase from 24 to 36 months was generally more pronounced in root than in leaf litter.

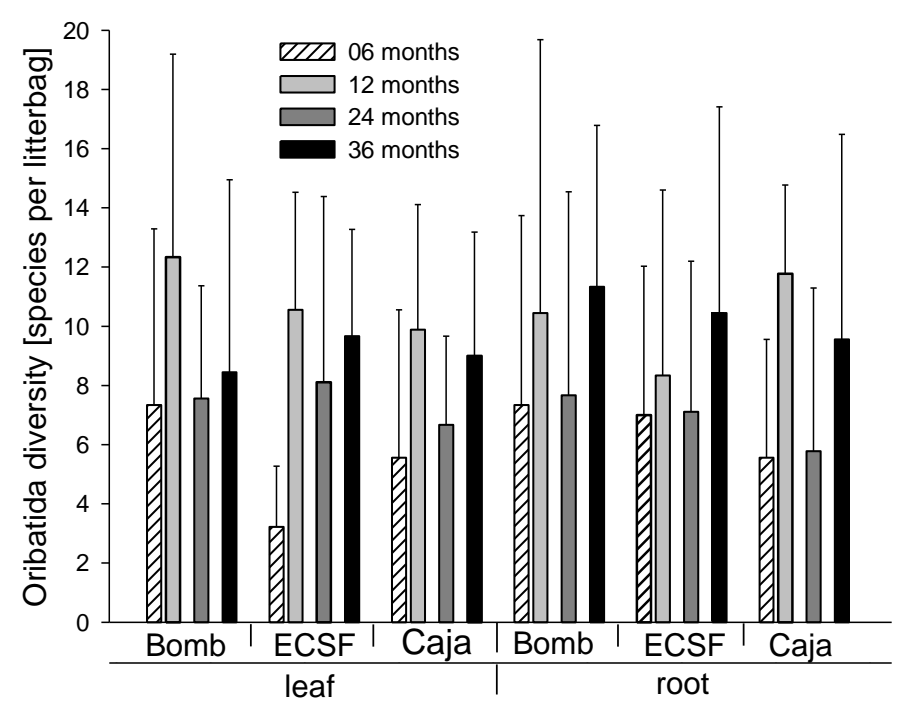

Fig. 3: Diversity of Oribatida in litterbags with leaf and root litter from three origins [Bombuscaro (Bomb), ECSF and Cajanuma (Caja)] exposed in tropical montane rainforests for 6, 12, 24 and 36 months (means \pm SD).

The number of species which exclusively occurred at one of the three study sites differed between the altitudes, with 63 species at $1000 \mathrm{~m}$ (33.4\% of the total species) compared to 23 species (12.1\%) and 29 species (15.3\%) at 2000 and 3000 m, respectively. The species overlap between altitudes was strongest between 1000 and 2000 m with 34 species present on both altitudes, compared to only 18 species which were present at both 1000 and $3000 \mathrm{~m}$ and 6 species present 
at 2000 and $3000 \mathrm{~m}$. Only $8.5 \%$ of species were present at all of the three altitudes. Species numbers differed only slightly between leaf and root litter. In leaf litter 157 of the total 189 species were present, compared to 150 species in root litter; $62.4 \%$ of the total species were present in both litter types.

\section{Community structure of Oribatida}

The Oribatida community in leaf litter varied most among the three altitudes, which separated along the first axis (Detrended Correspondence Analysis, DCA; Fig. 4a). The separation was stronger between 1000 and $2000 \mathrm{~m}$ as compared to 2000 and $3000 \mathrm{~m}$. The sampling dates at $1000 \mathrm{~m}$ separated along the second axis, while at 2000 and $3000 \mathrm{~m}$ the sampling dates were not as clearly separated. Most Oribatida species were associated with the $1000 \mathrm{~m}$ site and shifted along the temporal gradient, only few species were closely associated with the $3000 \mathrm{~m}$ site. From the total number of species in leaf litter $40.1 \%$ were only present at the $1000 \mathrm{~m}$ altitude, among them the only two Enarthronota species (Eohypochthonius gracilis and Enarthronotha sp.1). Notably, the Enarthronota family Brachychthoniidae, which was excluded from the ordination, reached high abundance at both 2000 and 3000 m (Appendix Fig. S2). Many parthenogenetic species were associated with the $1000 \mathrm{~m}$ altitude site, mainly belonging to the family of Suctobelbidae. At higher altitude the parthenogenetic species belonged to other taxonomic groups, such as Nanhermanniidae. The number of species which exclusively occurred in leaf litter was lowest at 2000 m with only $12.7 \%$ compared to $16.6 \%$ at $3000 \mathrm{~m}$, but due to the overall low abundances at $3000 \mathrm{~m}$ a higher number of the species only present at this altitude were excluded from the DCA due to the constraint of only including species present in more than two samples. Six of the species were exclusively present in leaf litter, Microtegeus similis, Borhidia cf. andina, Liebstadia n.sp. (1), Neoamerioppia longicoma, Suctobelbella variosetosa and Neosuctobelba transitoria. Apart from the last two all of the species were associated with the $3000 \mathrm{~m}$ altitude. The Oribatida community in root litter also varied most between the three altitudes, which separated along the first axis (Detrended Correspondence Analysis, DCA; Fig. 4b). Contrasting the pattern in leaf litter, here the sampling dates at $2000 \mathrm{~m}$ separated along the second axis, while at 1000 and $3000 \mathrm{~m}$ the sampling dates were not clearly separated. The Oribatida species in root litter also were mainly associated with the $1000 \mathrm{~m}$ site, with $60.0 \%$ of the species present at $1000 \mathrm{~m}$ being endemic at this altitude. Only few species were associated with the $3000 \mathrm{~m}$ site. Species exclusively present in root litter were Haplobelba simplex, Schalleria pectinata, Tecteremaeus cornutus and Cyrthermannia cf. florens which were associated with the $1000 \mathrm{~m}$ altitude site, as well as Sternoppia n.sp.(1), Solenozetes n.sp. and Kokoppia euramosa, which were associated with the higher altitude sites. In 
root litter it was even more evident that a higher number of parthenogenetic species was present at $1000 \mathrm{~m}$ as compared to 2000 and $3000 \mathrm{~m}$.

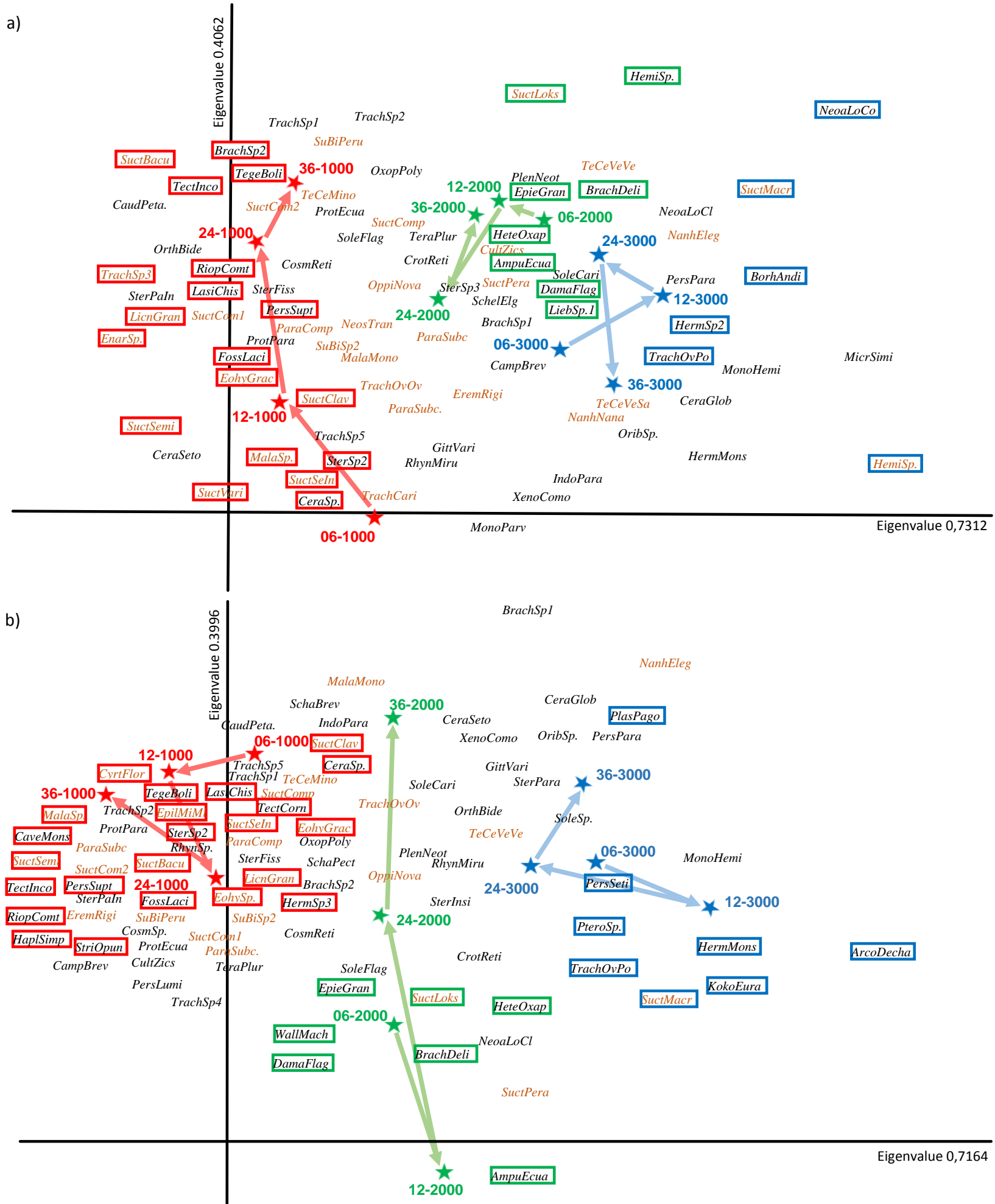

Fig. 4: DCA ordinations of Oribatida species in litterbags with (a) leaf and (b) root litter exposed at three altitudes $(1000,2000$ and $3000 \mathrm{~m})$ for 6, 12, 24 and 36 months. Consecutive sampling dates are linked by arrows. Species given in brown reproduce via parthenogenesis. Framed species are only present at one altitude $($ red $=1000 \mathrm{~m}$, green $=2000 \mathrm{~m}$, blue $=3000 \mathrm{~m}$ ). For full species names see Appendix. 


\section{Discussion}

Results of the present study suggest that in tropical montane rainforests the density and diversity of soil animals varies more with altitude and the degree to which the litter is decomposed than with litter origin and therefore quality of the litter material. At our study sites the origin of the litter material only affected the abundance of certain soil fauna groups at early sampling dates, i.e. after 6 or 12 months. This pattern fits well to the fact that the quality of the litter material only affected decomposition rates and microbial biomass of litter at early stages of decomposition (F. Marian, unpublished data, Chapter 2).

Densities of total fauna as well as the most abundant decomposer groups, Oribatida and Collembola, decreased with increasing altitude, suggesting that the two groups are structured by similar factors. A similar distribution pattern has been described for Oribatida along a smaller altitudinal gradient in the same study area as well as for different soil fauna groups in a montane rainforest in Puerto Rico (Richardson et al., 2005; Maraun et al., 2008; Illig et al., 2008, 2010). In the present study, only one Collembola group, Sminthuridae, showed a differing pattern with highest density at the intermediate altitude. Important factors driving the density of Oribatida include soil acidity, harshness of abiotic conditions, density of macroarthropods and litter quality (Maraun \& Scheu, 2000; Illig et al., 2010). For the studied montane rainforest in the Ecuadorian Andes Illig et al. (2010) suggested that among various factors studied driving Oribatida density, litter quality is the most important. In other regions changes in plant community structure have been shown to affect densities and composition of soil animals (Richardson et al., 2005; Sundqvist et al., 2013), although there are also studies pointing to a greater importance of regional abiotic factors (Erdmann et al., 2012). For a tropical rainforest in Puerto Rico, Richardson et al. (2005) suggested changes in abiotic conditions along an altitudinal gradient to be less important than the forest structure for both soil animal abundance and diversity, pointing in the same direction as the study of Illig et al. (2010). The results of the present study suggest that this influence of plant community structure on the abundance of decomposer animals is due to belowground characteristics of the plant community, mediated presumably via root exudates and mycorrhizal fungi and not due to litter quality changes. However, Leuschner et al. (2007) found the biomass of living roots to increase with increasing altitude suggesting that the amount of carbon directed towards the root system and the release of root exudates also increases with increasing altitude arguing against the suggestion that the density of soil mesofauna is driven by root-derived resources. Rather than the amount of living roots and root exudates, the quality of root litter may be important in determining the density of soil mesofauna as nitrogen concentration in root litter decreases with increasing altitude (F. Marian, unpublished data, Chapter 2 ) and root necromass accumulates at higher altitudes (Röderstein et al., 2005). 
Parallel to the decrease in decomposer fauna with increasing altitude, the density of the investigated predators also decreased, suggesting close interrelationships. While most Oribatida species are well defended and not preyed upon by mesofauna predators (Peschel et al., 2006; Schneider \& Maraun, 2009), Collembola are a common prey for Mesostigmata (Koehler, 1999), suggesting that the parallel decrease of Collembola and Mesostigmata along the altitudinal gradient is driven by a decrease in resource supply, i.e. by bottom-up control. In contrast, variations in the abundance of Prostigmata were not closely linked to the abundance of Collembola and did not differ between 2000 and 3000 m, indicating that Prostigmata predominantly rely on other prey than Collembola, potentially Nematoda.

At our study sites the density of Oribatida and Collembola varied between the two litter types with the density of Oribatida being lower in root as compared to leaf litter. This might have been due to the lower quality of root as compared to leaf litter; however, it may also be related to the fact that root litterbags were exposed deeper in the soil whereas leaf litterbags were placed on the soil surface. It is well documented that typically the density of soil mesofauna declines with soil depth (Berg et al., 1998). However, the density of Collembola did not show such a uniform response. Sminthuridae showed the expected pattern, reaching higher abundances in leaf litter, while Megalothorax, Isotomidae and at some altitudes Entomobryidae were more abundant in the root litterbags. Potentially, the latter Collembola taxa preferentially colonize deeper soil layers to evade predators as larger predators such as spiders and beetles predominantly forage in the porous space of leaf litter (Wagner et al., 2003). Preferential colonization of leaf litter by Sminthuridae is conform to the fact that they are closely associated with plants and at least in part live as herbivores feeding on higher plants, algae and lichens (Chahartaghi et al., 2005).

Parallel to density species richness of Oribatida declined with increasing altitude (Rahbek \& Museum, 1995; Richardson et al., 2005; Sanders et al., 2009; Willig \& Presley, 2015). A similar pattern has been described by Illig (2010) for a smaller altitudinal gradient and the pattern resembled that in tree diversity (Homeier et al., 2002, 2008; Paulsch et al., 2006). This points to a higher diversity of niches for soil mesofauna species at lower altitude associated with higher tree diversity.

Compared to temperate forests the diversity of Oribatida species at our study sites was rather high especially at the $1000 \mathrm{~m}$ site with 131 species compared to $60-80$ species in temperate forests (Erdmann et al., 2012). Investigating latitudinal gradients in species diversity in Oribatida, Maraun (2007) found species richness to increase little from temperate to tropical regions and our findings generally fit to this pattern. Low to moderate increase in species diversity in Oribatida contrasts the typically much higher species richness in tropical as compared to temperate regions in plants and aboveground animals in particular insects (Pianka, 1966; Hillebrand, 2004), but is consistent with 
the pattern in other soil animal taxa such as Lumbricidae and Nematoda (Judas, 1988; Boag \& Yeates, 1998; De Deyn \& Van Der Putten, 2005). This suggests that latitudinal gradients in species diversity differ in general between above and belowground biota as suggested earlier (De Deyn \& Van Der Putten, 2005). Notably, at our study sites species richness patterns in Oribatida matched with decomposition rates, suggesting that the diversity of soil fauna might drive litter decomposition as recently documented for a number of ecosystems (Handa et al., 2014).

The community structure of Oribatida varied strongly with altitude, with only a small number of species being present at each of the three altitudes and many species occurring at one altitude only (endemic species). This pattern highlights the strong turnover of species with altitude, i.e. high $\beta$-diversity. The turnover likely is driven by abiotic factors such as temperature, but potentially also by marked changes in vegetation structure with altitude. For temperate forests Erdmann et al. (2012) recently showed marked turnover of species in space in forests of similar species composition and age across Germany suggesting that species turnover in space in part is due to dispersal limitation.

Oribatida communities in soil of temperate and boreal forests typically are dominated by parthenogenetic individuals and high numbers of parthenogenetic species (Cianciolo \& Norton, 2006; Heethoff et al., 2009). Ranging between 23 and $35 \%$ the percentages of parthenogenetic species at our study sites were generally low as compared to temperate and boreal forests where it typically ranges between 80 and 95 \% (Maraun et al., 2003; Cianciolo \& Norton, 2006). The percentage of sexual Oribatida species and individuals increased with increasing altitude and this is consistent with earlier reports (Maraun et al., 2013). Notably, this pattern fits well to the model proposed by Scheu and Drossel (2007) predicting sexual species to be favoured by densitydependent factors and competition for resources. Both likely increase with altitude at our study sites as indicated by the decrease in density of Oribatida and the decline in resource quality at higher altitude.

The degree to which the litter material was decomposed also strongly influenced the abundance and diversity of the investigated soil animal taxa. Although interrelationships between litter decomposition and soil mesofauna have been widely studied (Heneghan et al., 1999; Scheu, 2002; Kampichler \& Bruckner, 2009; Castanho et al., 2012), little is known on changes in density and diversity of mesofauna taxa in decomposing leaf litter in the long term. In the present study the abundance of both decomposer groups, Oribatida and Collembola, varied strongly and in similar directions with sampling dates, suggesting that processes occurring during litter decomposition influence both taxa in a similar way. The diversity of Oribatida also varied between sampling dates, indicating that the availability of niches changes during decomposition. Although the abundance of both decomposer groups and Oribatida diversity varied with other factors investigated, including 
altitude, litter type and litter origin, temporal changes dominated, highlighting the importance of time as major driving factor. Decomposition processes at our study sites at 2000 and $3000 \mathrm{~m}$ can be divided into three phases (F. Marian, unpublished data, Chapter 2). Similarly, the abundance of the investigated decomposer groups and of Oribatida diversity followed a three phase-pattern. Notably, contrasting to microorganisms and litter decomposition, the pattern was very similar at each of the three altitudes. Recent studies using stable isotope labelling suggest that the decomposer community of forest ecosystems is little affected by the availability and quality of aboveground litter (Pollierer et al., 2007; Zieger et al., 2015). Rather, an increasing number of studies highlight the importance of root-derived resources for fuelling soil food webs. Root-derived carbon is incorporated in large amounts into mycorrhiza suggesting a close interaction between fungal feeding mesofauna and mycorrhizal fungi (Pollierer et al., 2007, 2012; Zieger et al., 2015). Apparently contradicting these findings, it has been shown that major soil fauna groups prefer saprotrophic over mycorrhizal fungi as food source (Gange, 2000; Tiunov \& Scheu, 2005). Potapov et al. (2015) also provided evidence that Collembola do not incorporate mycorrhizal carbon suggesting that root-derived carbon is incorporated via other pathways. Potentially, the assumed low importance of litter-derived carbon for the soil food web at least in part is due to carbon transfer into the soil mesofauna through the plant litter pathway being investigated by adding fresh undecomposed labelled leaves to the soil system (Pollierer et al., 2012; Zieger et al., 2015), thereby only following the fate of leaf litter carbon at the early stage of decomposition. On the other hand litter resources are known to become more important as food resources for soil detritivores at later stages of litter decomposition (Berg \& McClaugherty, 2008; Coulis et al., 2009), suggesting that studies pointing towards the importance of root-derived carbon underestimated the carbon input from old litter material.

The low abundance of Oribatida and Collembola at early stages of litter decomposition indicates that food quality of fresh litter material is of little relevance for detritivore microarthropods. This is surprising as it is decomposing fast at each of the three altitudes and contains easy-to-use soluble litter compounds and high biomass of microorganisms (F. Marian, unpublished data, Chapter 2). Low diversity of Oribatida after 6 months suggests that not only the abundance of soil fauna is reduced, but also that only a low number of Oribatida species are able to benefit from the nutrients released early during litter decomposition. As suggested earlier (F. Marian, unpublished data, Chapter 2), litter decomposition at early stages of decay at our study sites might be characterized by high activity of mycorrhizal fungi. Low abundance of Oribatida and Collembola during early phases of litter decomposition could therefore suggests that they do not feed intensively on mycorrhizal fungi or benefit from mycorrhiza-mediated changes in litter quality. 
The increase in mesofauna abundance after 12 months suggests that towards the end of the first phase of decomposition more resources are becoming available to the soil fauna community as decomposition continues. The strong parallel increase in Oribatida diversity, resulting in maximum diversity after 12 months in many of the treatments, suggests that after the initial colonization phase the community is becoming more complex. This indicates that by the end of the first phase of litter decomposition more niches for decomposer soil mesofauna species are becoming available. Notably, these changes are paralleled by changes in decomposition processes and microorganisms (F. Marian, unpublished data, Chapter 2).

In the second phase of decomposition from 12 to 24 months, soil mesofauna abundance of virtually all of the studied mesofauna groups as well as Oribatida species diversity declined and this was consistent in almost all treatments. Notably, in parallel the microbial community composition shifted with microbial biomass declining and litter decomposition slowing down or even coming to halt (F. Marian, unpublished data, Chapter 2). This suggests that decomposition, microbial biomass and mesofauna abundance are closely linked and driven by similar factors. Presumably, resource availability in the litter is at a minimum at this decomposition stage and the low resource level is insufficient to sustain microbial and mesofauna populations. Further, the decline in species diversity of Oribatida suggests that the decline in resources is associated with a decline in the number of trophic niches.

In the third phase of decomposition starting after 24 months, decomposition of litter resumed and was associated with an increase in microbial biomass (F. Marian, unpublished data, Chapter 2). This resumption of decomposition presumably was due to a shift in the microbial community, with bacteria and fungi able to decompose lignified compounds becoming more abundant (F. Marian, unpublished data, Chapter 2). Parallel to this shift the mesofauna abundance increased suggesting that initiation of the decomposition of recalcitrant litter compounds also increases resource supply for soil mesofauna. This may be due to either microorganisms themselves serving as food or the litter material becoming more palatable at late decomposition stages (Bardgett, 2005). As indicated by earlier studies, increased palatability of litter resources at later stages of decay might be due to the breakdown of phenolic litter compounds (Coulis et al., 2009) indicating that the importance of energy pathways varies over the course of decomposition. In the early stage of decomposition mesofauna presumably is fuelled mainly via the root pathway, while at later stages more resources are gained from decomposing litter material and/or associated microorganisms. These changes in the importance of energy channels also propagates to higher trophic levels, as indicated by the abundances of both Mesostigmata and Prostigmata following the pattern of decomposer abundance over the course of decomposition. The fact that this was less pronounced in Prostigmata 
as compared to Mesostigmata suggests that the latter more heavily rely on other food resources than decomposer microarthropods, presumably Nematoda.

The strong increase in species number of Oribatida from 24 to 36 months especially in root litter highlights that litter at late stage of decomposition - when bacteria and fungi decomposing complex litter compounds dominate (Marian, unpublished data, Chapter 2) provides ample resources and niches for decomposer microarthropods allowing coexistence of many species.

The community structure of Oribatida in leaf litter also changed during decomposition and this was most pronounced at the $1000 \mathrm{~m}$ study site. The less pronounced changes at the 2000 and $3000 \mathrm{~m}$ site suggest that Oribatida species at higher altitude are more generalist feeders exploiting a wider range of resources than the species at $1000 \mathrm{~m}$. However, the more continuous and faster decomposition of leaf litter at 1000 m (F. Marian, unpublished data, Chapter 2) may also have resulted in more pronounced changes in trophic niches and therefore changes in Oribatida community structure. The generally less pronounced changes in Oribatida community composition in decomposing root litter may have been due to the fact that root litter decomposed slower than leaf litter causing trophic niches to stay more constant. Further, the generally low quality of root litter may have selected for species which are able to live on poor resources preventing pronounced changes in community composition.

\section{Conclusions}

Overall, the results of the present long-term study suggest that the origin and therefore quality of litter material is of little importance as driving force for the composition of the microarthropod community of tropical montane rainforests. Factors changing with altitude, such as temperature and soil $\mathrm{pH}$, are much more important, with the abundance of microarthropods as well as the diversity of Oribatida decreasing with increasing altitude. Beside altitude decomposition stage was the second most important factor driving the density of microarthropods and diversity of Oribatida. Notably, these changes were closely associated with changes in the speed of litter decomposition and associated changes in microorganisms. Despite the generally poor resource quality, microorganisms efficiently exploit litter resources during the early phase of decomposition and this phase presumably is associated with the depletion of easily available litter compounds exploited by root-associated microorganisms including mycorrhiza. Surprisingly, microarthropods are unable to benefit from the flourishing of these microorganisms, potentially due to the presence of plant secondary compounds such as phenols. At later stages of decomposition when recalcitrant compounds are being attacked by saprotrophic microorganisms, such as lignin-degrading fungi, microarthropods are becoming more abundant and diverse either due to benefiting from feeding on these microorganisms or by indirectly benefiting from the conditioning of the litter by microbial 
enzyme production. The results of the present study highlight the role of altitude and the degree of decomposition for the importance of litter-derived resources as food source for decomposers. Further research into long-term decomposition processes is needed to reconcile the ongoing debate on the relative importance of the root and litter energy channel in fuelling soil food webs.

\section{Acknowledgements}

Financial support was provided by the German Research Foundation (DFG) within the scope of the Research Unit 816 "Tropical Mountain Forest (TMF): Biodiversity \& Sustainable Management of a Mega Diverse Mountain Ecosystem in South Ecuador".

Measurements of $\mathrm{C}$ and $\mathrm{N}$ contents were performed by Ute Schlonsog in the laboratory of Prof. Dr. Christoph Leuschner (Göttingen/Germany).

We thank the German and Ecuadorian students and helpers for their support in the establishment of the experimental field sites, with collection of samples and their work in the laboratory.

\section{References}

Balogh J, Balogh P. 1988. Oribatid Mites of the neotropical region 1\&2. Elsevier Sience Publishers.

Balogh J, Balogh P. 2002. Identification Keys to the Oribatid Mites of the Extra-Holarctic Regions 1\&2. Miskolc.

Bardgett RD. 2005. The Biology of Soil: A community and ecosystem approach. Oxford: Oxford University Press.

Bardgett RD, Bowman WD, Kaufmann R, Schmidt SK. 2005. A temporal approach to linking aboveground and belowground ecology. Trends in ecology \& evolution 20: 634-641.

Berg B. 2014. Decomposition patterns for foliar litter - A theory for influencing factors. Soil Biology and Biochemistry 78: 222-232.

Berg MP, Kniese JP, Bedaux JJM, Verhoef HA. 1998. Dynamics and stratification of functional groups of micro- and mesoarthropods in the organic layers of a scots pine forest soil. Biol Fertil Soils 26: 268-284.

Berg B, McClaugherty C. 2008. Plant Litter: Decomposition, Humus Formation, Carbon Sequestration. Berlin, Heidelberg: Springer Verlag.

Boag B, Yeates GW. 1998. Soil nematode biodiversity in terrestrial ecosystems. Biodiversity and Conservation 7: 617-630.

Butenschoen O, Krashevska V, Maraun M, Marian F, Sandmann D, Scheu S. 2014. Litter mixture effects on decomposition in tropical montane rainforests vary strongly with time and turn negative at later stages of decay. Soil Biology and Biochemistry 77: 121-128.

Castanho CT, Lorenzo L, de Oliveira AA. 2012. The importance of mesofauna and decomposition environment on leaf decomposition in three forests in southeastern Brazil. Plant Ecology 213: 1303-1313. 
Chahartaghi M, Langel R, Scheu S, Ruess L. 2005. Feeding guilds in Collembola based on nitrogen stable isotope ratios. Soil Biology and Biochemistry 37: 1718-1725.

Cianciolo JM, Norton RA. 2006. The ecological distribution of reproductive mode in oribatid mites, as related to biological complexity. Experimental and Applied Acarology 40: 1-25.

Cornwell WK, Cornelissen JHC, Amatangelo K, Dorrepaal E, Eviner VT, Godoy O, Hobbie SE, Hoorens B, Kurokawa H, Pérez-Harguindeguy N, et al. 2008. Plant species traits are the predominant control on litter decomposition rates within biomes worldwide. Ecology Letters 11: 1065-1071.

Coulis M, Hättenschwiler S, Rapior S, Coq S. 2009. The fate of condensed tannins during litter consumption by soil animals. Soil Biology and Biochemistry 41: 2573-2578.

Coûteaux M-M, Bottner P, Berg B. 1995. Litter decomposition, climate and litter quality. Trends in Ecology and Evolution 10: 63-66.

Coûteaux M-M, Sarmiento L, Bottner P, Acevedo D, Thiéry JM. 2002. Decomposition of standard plant material along an altitudinal transect $(65-3968 \mathrm{~m})$ in the tropical Andes. Soil Biology and Biochemistry 34: 69-78.

Cusack DF, Chou WW, Yang WH, Harmon ME, Silver WL. 2009. Controls on long-term root and leaf litter decomposition in neotropical forests. Global Change Biology 15: 1339-1355.

Davidson EA, Janssens IA. 2006. Temperature sensitivity of soil carbon decomposition and feedbacks to climate change. Nature 440: 165-173.

De Deyn GB, Van Der Putten WH. 2005. Linking aboveground and belowground diversity. Trends in Ecology and Evolution 20: 625-633.

Erdmann G, Scheu S, Maraun M. 2012. Regional factors rather than forest type drive the community structure of soil living oribatid mites (Acari, Oribatida). Experimental and Applied Acarology 57: 157-169.

Ettema CH, Wardle DA. 2002. Spatial soil ecology. Trends in Ecology and Evolution 17: 177-183.

Gange A. 2000. Arbuscular mycorrhizal fungi, Collembola and plant growth. Trends in ecology \& evolution 15: 369-372.

Graefe S, Hertel D, Leuschner C. 2008. Fine root dynamics along a 2,000 m elevation transect in South Ecuadorian mountain rainforests. Plant and Soil 313: 155-166.

Handa T, Aerts R, Berendse F, Berg MP, Bruder A, Butenschoen O, Chauvet E, Gessner MO, Jabiol J, Makkonen M, et al. 2014. Consequences of biodiversity loss for litter decomposition across biomes. Nature 509: 218-221.

Heethoff M, Norton RA, Scheu S, Maraun M. 2009. Parthenogenesis in Oribatid mites (Acari, Oribatida): Evolution without sex. In: Schön I,, In: Martens K,, In: van Dijk P, eds. Lost Sex: The Evolutionary Biology of Parthenogenesis. Springer, 295-316.

Heneghan L, Coleman DC, Zou X, Crossley DA, Haines BL. 1999. Soil microarthropod contributions to decomposition dynamics: Tropical-temperate comparisons of a single substrate. Ecology 80: 1873-1882.

Hillebrand H. 2004. On the generality of the latitudinal diversity gradient. The American naturalist 163: $192-211$.

Homeier J, Breckle S-W, Günter S, Rollenbeck RT, Leuschner C. 2010. Tree diversity, forest structure and productivity along altitudinal and topographical gradients in a species-rich Ecuadorian montane rain forest. Biotropica 42: 140-148. 
Homeier J, Dalitz H, Breckle S-W. 2002. Waldstruktur und Baumdiversität im montanen Regenwald der Estación Cientifíca San Francisco in Südecuador. Bericht der Reinhessischen TüxenGesellschaft 14: 109-118.

Homeier J, Werner FA, Gradstein SR, Breckle S-W, Richter M. 2008. Potential vegetation and floristic composition of andean forests in South Ecuador, with a focus on the RBSF. In: Beck $E_{,}$, In: Kottke I,, In: Makeschin F,, In: Mosandl R, In: Bendix J, eds. Ecological Studies: Gradients in tropical mountain ecosystem of Ecuador. Berlin: Springer Verlag, Berlin, Heidelberg, 87-100.

Illig J, Norton RA, Scheu S, Maraun M. 2010. Density and community structure of soil- and barkdwelling microarthropods along an altitudinal gradient in a tropical montane rainforest. Experimental and Applied Acarology 52: 49-62.

Illig J, Schatz H, Scheu S, Maraun M. 2008. Decomposition and colonization by micro-arthropods of two litter types in a tropical montane rain forest in southern Ecuador. Journal of Tropical Ecology 24: 157-167.

Judas M. 1988. The species-area relationship of European Lumbricidae (Annelida, Oligochaeta). Oecologia 76: 579-587.

Kampichler C, Bruckner A. 2009. The role of microarthropods in terrestrial decomposition: a metaanalysis of 40 years of litterbag studies. Biological reviews of the Cambridge Philosophical Society 84: 375-389.

Kempson D, Lloyd M, Ghelardi R. 1963. A new extractor for woodland litter. Pedobiologia 3: 1-21.

Kirschbaum MUF. 1995. The temperature dependence of soil organic matter decomposition, and the effect of global warming on soil organic C storage. Soil Biology and Biochemistry 27: 753-760.

Koehler HH. 1999. Predatory mites (Gamasina, Mesostigmata). Agriculture, Ecosystems and Environment 74: 395-410.

Krantz GW, Behan-Pelletier V, Cook DR, Harvey MS, Keirans JE, Lidquist EE, Norton R a., OConnor BM, Smith IM, Walter D. 2009. A Manual of Acarology (GW Krantz and DE Walter, Eds.). Texas Tech University Press.

Lepš J, Šmilauer P. 2003. Multivariate analysis of ecological data using CANOCO. Cambridge: Cambridge University Press.

Leuschner C, Moser G, Bertsch C, Röderstein M, Hertel D. 2007. Large altitudinal increase in tree root/shoot ratio in tropical mountain forests of Ecuador. Basic and Applied Ecology 8: 219230.

Maraun M, Fronczek S, Marian F, Sandmann D, Scheu S. 2013. More sex at higher altitudes: Changes in the frequency of parthenogenesis in oribatid mites in tropical montane rain forests. Pedobiologia 56: 185-190.

Maraun M, Salamon JA, Schneider K, Schaefer M, Scheu S. 2003. Oribatid mite and collembolan diversity, density and community structure in a moder beech forest (Fagus sylvatica): Effects of mechanical perturbations. Soil Biology and Biochemistry 35: 1387-1394.

Maraun M, Sandmann D, Krashevska V, Norton RA, Scheu S. 2008. Soil Fauna. In: Beck E,, In: Bendix J,, In: Kottke I,, In: Makeschin F,, In: Mosandl R, eds. Gradients in a Tropical Mountain Ecosystem of Ecuador (Ecological Studies 198). Springer-Verlag Berlin, 181-192.

Maraun M, Schatz H, Scheu S. 2007. Awesome or ordinary? Global diversity patterns of oribatid mites. Ecography 30: 209-216. 
Maraun M, Scheu S. 2000. The structure of oribatid mite communities (Acari, Oribatida): patterns, mechanisms and implications for future research. Ecography 23: 374-383.

Maraun M, Visser S, Scheu S. 1998. Oribatid mites enhance the recovery of the microbial community after a strong disturbance. Applied Soil Ecology 9: 175-181.

McNaughton SJ, Oesterheld M, Frank DA, Williams KJ. 1989. Ecosystem-level patterns of primary productivity and herbivory in teresstrial habitats. Nature 341: 142-144.

Mittelbach GG, Steiner CF, Scheiner SM, Gross KL, Reynolds HL, Waide RB, Willig MR, Dodson SI, Gough L. 2001. What is the observed relationship between species richness and productivity? Ecological Society of America 82: 2381-2396.

Moore JC, Walter DE, Hunt HW. 1988. Arthropod regulation of micro- and mesobiota in belowground detrital food webs. Annual Review of Entomology 33: 419-439.

Moser G, Hertel D, Leuschner C. 2007. Altitudinal change in LAI and stand leaf biomass in tropical montane forests: a transect study in Ecuador and a pan-tropical meta-analysis. Ecosystems 10: 924-935.

Myers N, Mittermeier RA, Mittermeier CG, da Fonseca GAB, Kent J. 2000. Biodiversity hotspots for conservation priorities. Nature 403: 853-858.

Palacios-Vargas JG, Castano-Meneses G, Gomez-Anaya JA, Martinez-Yrizar A, Mejia-Recamier BE, Martinez-Sanchez J. 2007. Litter and soil arthropods diversity and density in a tropical dry forest ecosystem in Western Mexico. Biodiversity and Conservation 16: 3703-3717.

Paulsch A, Piechowski D, Müller-Hohenstein K. 2006. Forest vegetation structure along an altitudinal gradient in southern Ecuador. In: Beck E,, In: Bendix J,, In: Kottke I,, In: Makeschin $F$, In: Mosandl R, eds. Gradients in a tropical mountain ecosystem of Ecuador. SpringerVerlag Berlin, 113-121.

Peschel K, Norton RA, Scheu S, Maraun M. 2006. Do oribatid mites live in enemy-free space? Evidence from feeding experiments with the predatory mite Pergamasus septentrionalis. Soil Biology and Biochemistry 38: 2985-2989.

Pianka ER. 1966. Latitudinal gradients in species diversity: a review of concepts. American Naturalist 100: 33-46.

Pollierer MM, Dyckmans J, Scheu S, Haubert D. 2012. Carbon flux through fungi and bacteria into the forest soil animal food web as indicated by compound-specific $13 \mathrm{C}$ fatty acid analysis (K Treseder, Ed.). Functional Ecology 26: 978-990.

Pollierer MM, Langel R, Körner C, Maraun M, Scheu S. 2007. The underestimated importance of belowground carbon input for forest soil animal food webs. Ecology letters 10: 729-736.

Post WM, Emanuel WR, Zinke PJ, Stangenberger AG. 1982. Soil carbon pools and world life zones. Nature 298: 156-159.

Potapov AM, Tiunov A V. 2015. Stable isotope composition of mycophagous collembolans versus mycotrophic plants: Do soil invertebrates feed on mycorrhizal fungi? Soil Biology and Biochemistry 93: 115-118.

van der Putten WH, Bardgett RD, De Ruiter PC, Hol WHG, Meyer KM, Bezemer TM, Bradford MA, Christensen S, Eppinga MB, Fukami T, et al. 2009. Empirical and theoretical challenges in aboveground-belowground ecology. Oecologia 161: 1-14.

Rahbek C, Museum Z. 1995. The elevational gradient of species richness: a uniform pattern? Ecography 2: 200-205. 
Richardson BA, Richardson MJ, Soto-Adames FN. 2005. Separating the effects of forest type and elevation on the diversity of litter invertebrate communities in a humid tropical forest in Puerto Rico. Journal of Animal Ecology 74: 926-936.

Röderstein M, Hertel D, Leuschner C. 2005. Above- and below-ground litter production in three tropical montane forests in southern Ecuador. Journal of Tropical Ecology 21: 483-492.

Sanders NJ, Dunn RR, Fitzpatrick MCF, Carlton CE, Pogue MR, Parker CR, Simons TR. 2009. Diverse elevational diversity gradients in Great Smoky Mountains National Park, USA. In: Spehn EM,, In: Körner C, eds. Data Mining for Global Trends inMountain Biodiversity. Boca Raton, FL:CRC Press, 75-88.

Schaefer M, Ansorge H, Fiedler K, Sattler K, Scheu S, Schmidt E. 2010. Brohmer - Fauna von Deutschland (M Schaefer, Ed.). Wiebelsheim: Quelle \& Meyer Verlag.

Scheu S. 2001. Plants and generalist predators as links between the below-ground and aboveground system. Basic and Applied Ecology 13: 3-13.

Scheu S. 2002. The soil food web: structure and perspectives. European Journal of Soil Biology 38: 11-20.

Scheu S, Drossel B. 2007. Sexual reproduction prevails in a world of structured resources in short supply. Proceedings of the Royal Society B: Biological Sciences 274: 1225-1231.

Schneider K, Maraun M. 2009. Top-down control of soil microarthropods - Evidence from a laboratory experiment. Soil Biology and Biochemistry 41: 170-175.

Schneider K, Migge S, Norton RA, Scheu S, Langel R, Reineking A, Maraun M. 2004. Trophic niche differentiation in soil microarthropods (Oribatida, Acari): evidence from stable isotope ratios (15N/14N). Soil Biology and Biochemistry 36: 1769-1774.

Seastedt TR. 1984. The role of microarthropods in decomposition and mineralization prozesses. Annual Review of Entomology 29: 25-46.

Subias LS. 2015. Listado sistemático, sinonímico y biogeográfico de los ácaros oribátidos (Acariformes: Oribatida) del mundo (excepto fósiles),. http://www.ucm.es/info/zoo/Artropodos/Catalogo.pdf/: 564.

Sundqvist MK, Sanders NJ, Wardle D a. 2013. Community and ecosystem responses to elevational gradients: Processes, mechanisms, and insights for global change. Annual Review of Ecology, Evolution, and Systematics 44: 261-280.

Tiunov A V., Scheu S. 2005. Arbuscular mycorrhiza and Collembola interact in affecting community composition of saprotrophic microfungi. Oecologia 142: 636-642.

Wagner JD, Toft S, Wise DH. 2003. Spatial stratification in litter depth by forest-floor spiders. The Journal of Arachnology 31: 28-39.

Wardle DA, Bardgett RD, Klironomos JN, Setälä H, van der Putten WH, Wall DH. 2004. Ecological linkages between aboveground and belowground biota. Science (New York, N.Y.) 304: 1629-1633.

Wardle DA, Yeates GW, Barker GM, Bonner KI. 2006. The influence of plant litter diversity on decomposer abundance and diversity. Soil Biology and Biochemistry 38: 1052-1062.

Weigmann G. 2006. Die Tierwelt Deutschlands - Hornmilben (Oribatida). Keltern: Verlag Goecke \& Evers. 
Wilcke W, Oelmann Y, Schmitt A, Valarezo C, Zech W, Homeier J. 2008. Soil properties and tree growth along an altitudinal transect in Ecuadorian tropical montane forest. Journal of Plant Nutrition and Soil Science 171: 220-230.

Willig MR, Presley SJ. 2015. Biodiversity and metacommunity structure of animals along altitudinal gradients in tropical montane forests. Journal of Tropical Ecology: 1-16.

Zieger SL, Eissfeller V, Maraun M, Scheu S. 2015. Incorporation of carbon and nitrogen from leaf litter differing in structural compounds into soil microarthropods of a deciduous forest. Pedobiologia 58: 219-227. 


\section{Appendix}

Table S1: Repeated measures GLM table of F- and p-values on the effect of altitude (1000, 2000 and $3000 \mathrm{~m})$, litter type (roots or leaves), litter origin [Bombuscaro (Bomb), ECSF and Cajanuma (Caja)] and date (6, 12, 24 and 36 months) on the abundance of Brachychthoniidae, Galumnidae, Mesoplophoridae, Euphthiracaridae and Phthiracaridae. Significant effects are given in bold.

\begin{tabular}{|c|c|c|c|c|c|c|c|c|c|c|}
\hline & \multicolumn{2}{|c|}{ Brachychthoniidae } & \multicolumn{2}{|c|}{ Galumnidae } & \multicolumn{2}{|c|}{ Mesoplophoridae } & \multicolumn{2}{|c|}{ Euphthiracaridae } & \multicolumn{2}{|c|}{ Phthiracaridae } \\
\hline & F-values & p-values & F-values & p-values & F-values & p-values & F-values & p-values & F-values & p-values \\
\hline \multicolumn{11}{|l|}{ Between subject effects } \\
\hline altitude & 12.31 & $<.0001$ & 10.34 & 0.0003 & 6.15 & 0.005 & 23.09 & $<.0001$ & 0.05 & 0.9518 \\
\hline origin & 0.43 & 0.6556 & 0.65 & 0.5274 & 0.7 & 0.5008 & 0.47 & 0.6271 & 1.15 & 0.3275 \\
\hline altitude $\times$ origin & 0.26 & 0.9037 & 0.69 & 0.6016 & 1.14 & 0.3547 & 0.78 & 0.5438 & 1.12 & 0.3612 \\
\hline type & 14.2 & 0.0006 & 1.37 & 0.25 & 0.32 & 0.5751 & 1.84 & 0.1832 & 3.45 & 0.0715 \\
\hline altitude $\times$ type & 3.42 & 0.0436 & 0.81 & 0.4526 & 0.08 & 0.92 & 0.94 & 0.4001 & 7.53 & 0.0019 \\
\hline origin $\times$ type & 1.12 & 0.3378 & 0.26 & 0.7734 & 0.34 & 0.7112 & 1.08 & 0.35 & 0.74 & 0.4846 \\
\hline altitude $\times$ origin $\times$ type & 0.71 & 0.5886 & 0.48 & 0.7485 & 0.31 & 0.8722 & 0.93 & 0.4565 & 0.48 & 0.7471 \\
\hline \multicolumn{11}{|l|}{ Within subject effects } \\
\hline date & 31.92 & $<.0001$ & 8.54 & $<.0001$ & 0.41 & 0.744 & 7.32 & 0.0002 & 4.24 & 0.0071 \\
\hline date $\times$ altitude & 2.92 & 0.0112 & 1.58 & 0.1612 & 0.43 & 0.8591 & 2.68 & 0.0182 & 1.75 & 0.1174 \\
\hline date $\times$ origin & 0.9 & 0.4954 & 0.77 & 0.5969 & 1.41 & 0.2158 & 0.37 & 0.8944 & 1.36 & 0.2362 \\
\hline date $\times$ altitude $\times$ origin & 0.56 & 0.8673 & 0.56 & 0.8708 & 1.15 & 0.3322 & 2.16 & 0.0188 & 1.25 & 0.2575 \\
\hline date $\times$ type & 1.55 & 0.2052 & 1.68 & 0.1745 & 0.72 & 0.5425 & 1.78 & 0.1552 & 3.71 & 0.0138 \\
\hline date $\times$ altitude $\times$ type & 2.61 & 0.0212 & 1.61 & 0.1526 & 0.76 & 0.6025 & 2.71 & 0.0174 & 1.36 & 0.2387 \\
\hline date $\times$ origin $\times$ type & 0.61 & 0.7225 & 2.41 & 0.0318 & 0.98 & 0.4418 & 0.59 & 0.7394 & 0.38 & 0.89 \\
\hline date $\times$ altitude $\times$ origin $\times$ type & 0.75 & 0.7034 & 1.27 & 0.2477 & 0.45 & 0.9381 & 0.72 & 0.7279 & 0.97 & 0.4815 \\
\hline
\end{tabular}

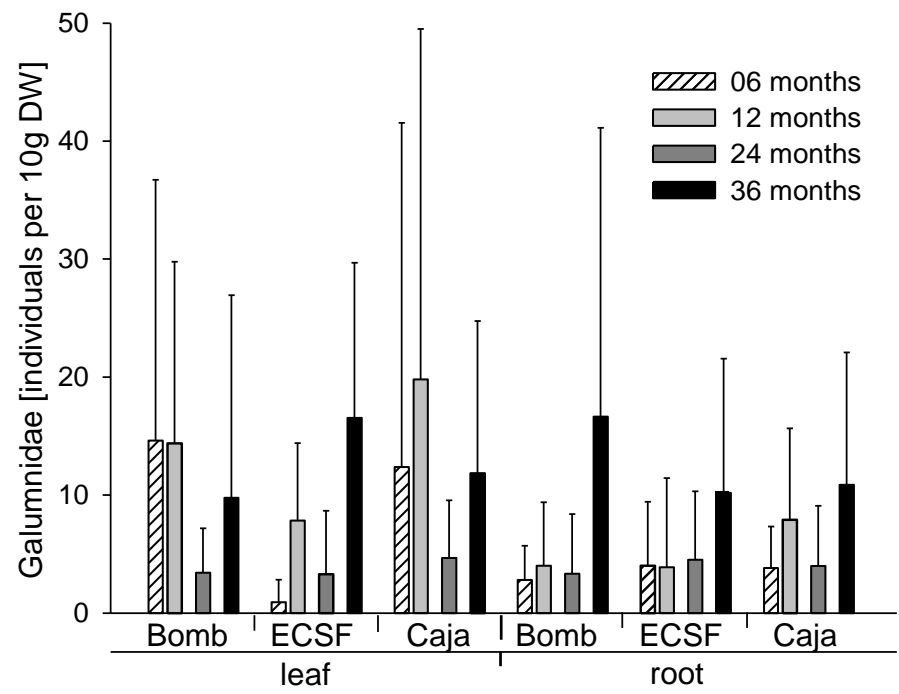

Fig. S1: Abundance of Galumnidae in leaf and root litter from three origins [Bombuscaro (Bomb), ECSF and Cajanuma (Caja)] exposed in tropical montane rainforests for 6, 12, 24 and 36 months (means $\pm S D$ ). 


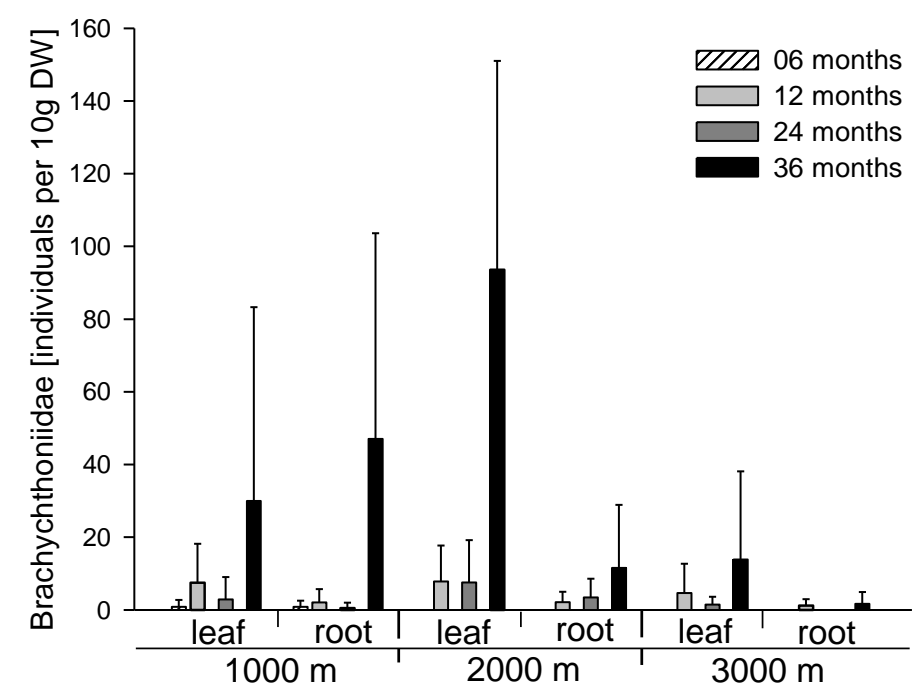

Fig. S2: Abundance of Brachychthoniidae in litterbags with leaf and root litter exposed in tropical montane rainforests at three altitudes (1000, 2000 and $3000 \mathrm{~m}$ ) for 6, 12, 24 ,36 and 48 months (means \pm SD).

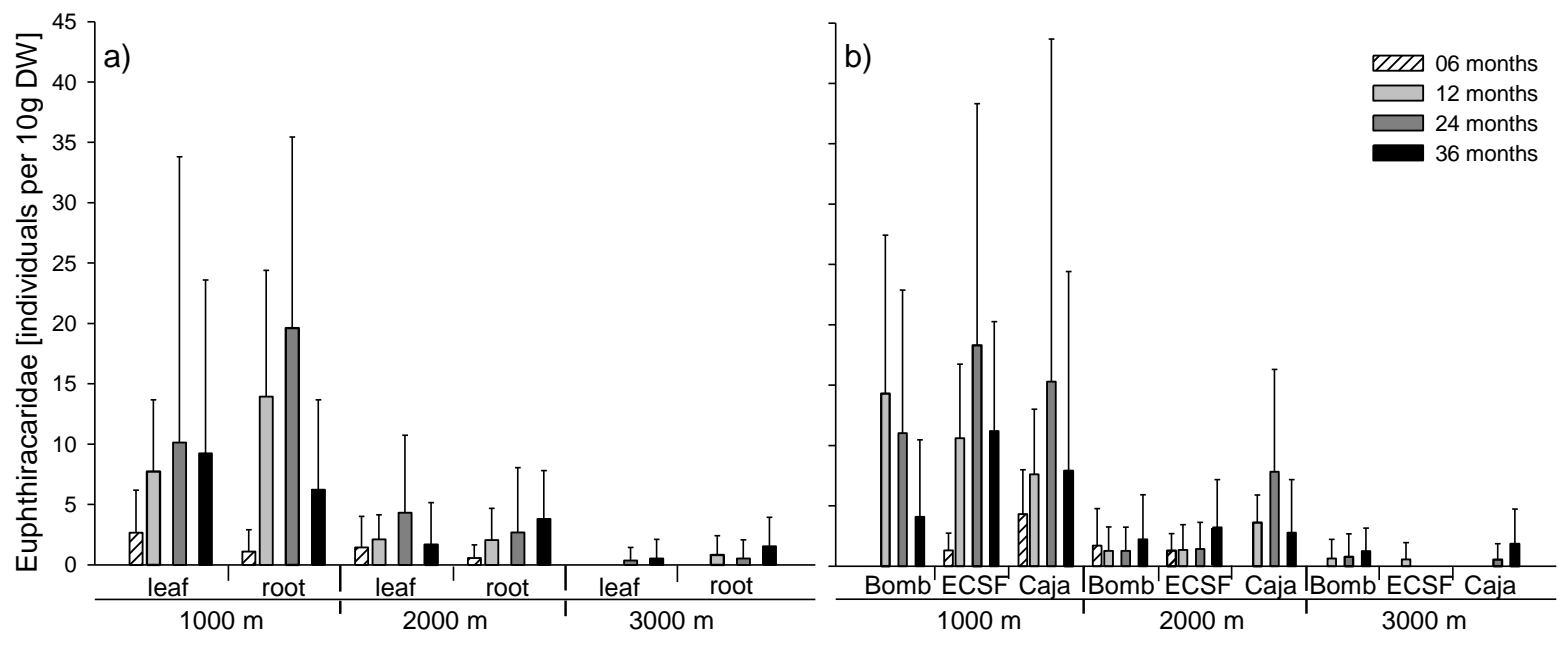

Fig. S3: Abundance of Euphthiracaridae in (a) leaf and root litter placed at three altitudes (1000, 2000 and $3000 \mathrm{~m}$ ) and (b) leaf and root litter from three origins (Bomb, ECSF and Caja) exposed in tropical montane rainforests for $6,12,24$ and 36 months (means $\pm S D$ ). 
Table S2: Repeated measures GLM table of F- and p-values on the effect of altitude (1000, 2000 and $3000 \mathrm{~m})$, litter type (roots or leaves), litter origin [Bombuscaro (Bomb), ECSF and Cajanuma (Caja)] and date (6, 12, 24 and 36 months) on the abundance of the Collembola morphogroups Entomobryidae, Hypogastruridae/Neanuridae (Hypogast/Neanu), Isotomidae, Megalothorax and Sminthuridae. Significant effects are given in bold.

\begin{tabular}{|c|c|c|c|c|c|c|c|c|c|c|}
\hline & \multicolumn{2}{|c|}{ Entomobyridae } & \multicolumn{2}{|c|}{ Hypogast/Neanu } & \multicolumn{2}{|c|}{ Isotomidae } & \multicolumn{2}{|c|}{ Megalothorax } & \multicolumn{2}{|c|}{ Sminthuridae } \\
\hline & $\begin{array}{c}\mathrm{F}- \\
\text { values }\end{array}$ & $\begin{array}{c}\mathbf{p}- \\
\text { values }\end{array}$ & $\begin{array}{c}\text { F- } \\
\text { values }\end{array}$ & $\begin{array}{c}\text { p- } \\
\text { values }\end{array}$ & $\begin{array}{c}\text { F- } \\
\text { values }\end{array}$ & $\begin{array}{c}\text { p- } \\
\text { values }\end{array}$ & $\begin{array}{c}\mathrm{F}- \\
\text { values }\end{array}$ & $\begin{array}{c}\text { p- } \\
\text { values }\end{array}$ & $\begin{array}{c}\text { F- } \\
\text { values }\end{array}$ & $\begin{array}{c}\mathrm{p}- \\
\text { values }\end{array}$ \\
\hline \multicolumn{11}{|l|}{ Between subject effects } \\
\hline altitude & 13.68 & $<.0001$ & 27.76 & $<.0001$ & 72.93 & $<.0001$ & 8.31 & 0.0011 & 3.96 & 0.0278 \\
\hline origin & 2.92 & 0.0666 & 1.73 & 0.1909 & 2.32 & 0.1128 & 0.2 & 0.8227 & 1.16 & 0.326 \\
\hline altitude*origin & 0.7 & 0.5975 & 1.17 & 0.3384 & 0.2 & 0.9369 & 0.43 & 0.7876 & 0.92 & 0.4648 \\
\hline type & 1.54 & 0.2233 & 0.41 & 0.5267 & 11.09 & 0.002 & 15.58 & 0.0004 & 12.88 & 0.001 \\
\hline altitude*type & 5.91 & 0.006 & 0.66 & 0.5245 & 0.82 & 0.4464 & 3.85 & 0.0305 & 0.08 & 0.9278 \\
\hline origin*type & 0.21 & 0.8078 & 1.31 & 0.2828 & 0.72 & 0.4928 & 1.75 & 0.188 & 1.88 & 0.1678 \\
\hline altitude*origin*type & 1.91 & 0.1295 & 0.44 & 0.7819 & 0.33 & 0.8536 & 0.16 & 0.957 & 0.5 & 0.7331 \\
\hline \multicolumn{11}{|l|}{ Within subject effects } \\
\hline date & 24.67 & $<.0001$ & 4.35 & 0.0062 & 67.2 & $<.0001$ & 25.7 & $<.0001$ & 26.79 & $<.0001$ \\
\hline date*altitude & 6.33 & $<.0001$ & 1.15 & 0.3404 & 3.74 & 0.002 & 3.26 & 0.0055 & 1.65 & 0.1396 \\
\hline date*origin & 1.99 & 0.0732 & 0.4 & 0.8778 & 1.9 & 0.0867 & 0.63 & 0.7095 & 2.28 & 0.0413 \\
\hline date*altitude*origin & 1.36 & 0.1947 & 0.63 & 0.8154 & 1.1 & 0.365 & 1.96 & 0.0353 & 1.34 & 0.2079 \\
\hline date*type & 5.29 & 0.0019 & 3.44 & 0.0195 & 2.92 & 0.0372 & 8.79 & $<.0001$ & 3.32 & 0.0225 \\
\hline date*altitude*type & 0.13 & 0.9923 & 1.61 & 0.1505 & 1.44 & 0.2056 & 3.18 & 0.0066 & 2 & 0.0718 \\
\hline date*origin*type & 0.85 & 0.5326 & 0.54 & 0.7768 & 1.97 & 0.0758 & 0.6 & 0.726 & 1.49 & 0.1891 \\
\hline date*altitude*origin*type & 1.36 & 0.1975 & 0.75 & 0.7008 & 0.83 & 0.6204 & 1.06 & 0.3991 & 2.54 & 0.0055 \\
\hline
\end{tabular}




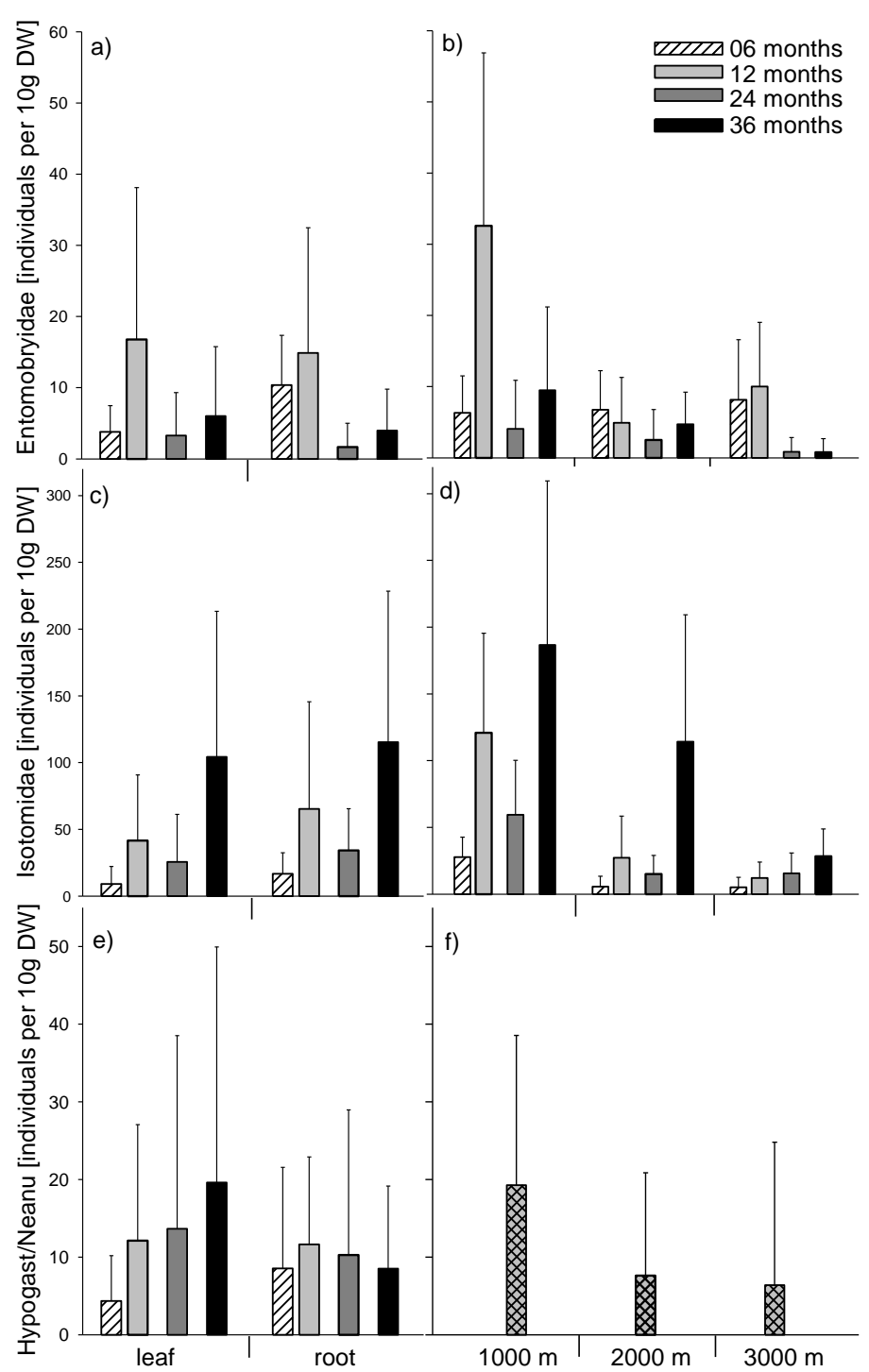

Fig. S4: Abundance Entomobryidae ( $a$ and $b$ ), Isotomidae ( $c$ and $d$ ) and Hypogastruridae/Neanuridae (e and $f$ ) in leaf and root litter (a, c, e) and at three altitudes (1000, 2000 and $3000 \mathrm{~m})(\mathrm{b}, \mathrm{d}, \mathrm{f})$ exposed in tropical montane rainforests for $6,12,24$ and 36 months (means $\pm S D$ ).

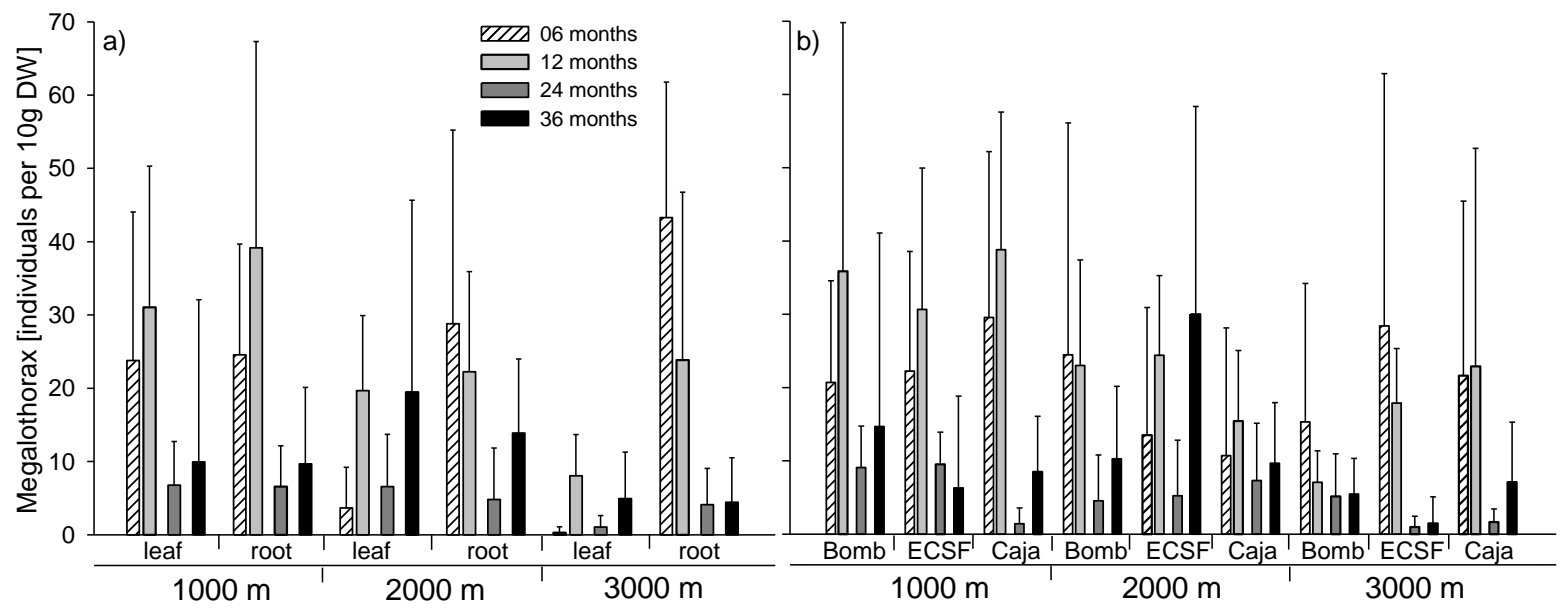

Fig. S5: Abundance of Megalothorax in (a) leaf and root litter placed at three altitudes (1000, 2000 and $3000 \mathrm{~m}$ ) and (b) litter from three origins [Bombuscaro (Bomb), ECSF and Cajanuma (Caja)] placed at three altitudes exposed in tropical montane rainforests for 6, 12, 24 and 36 months (means \pm SD). 


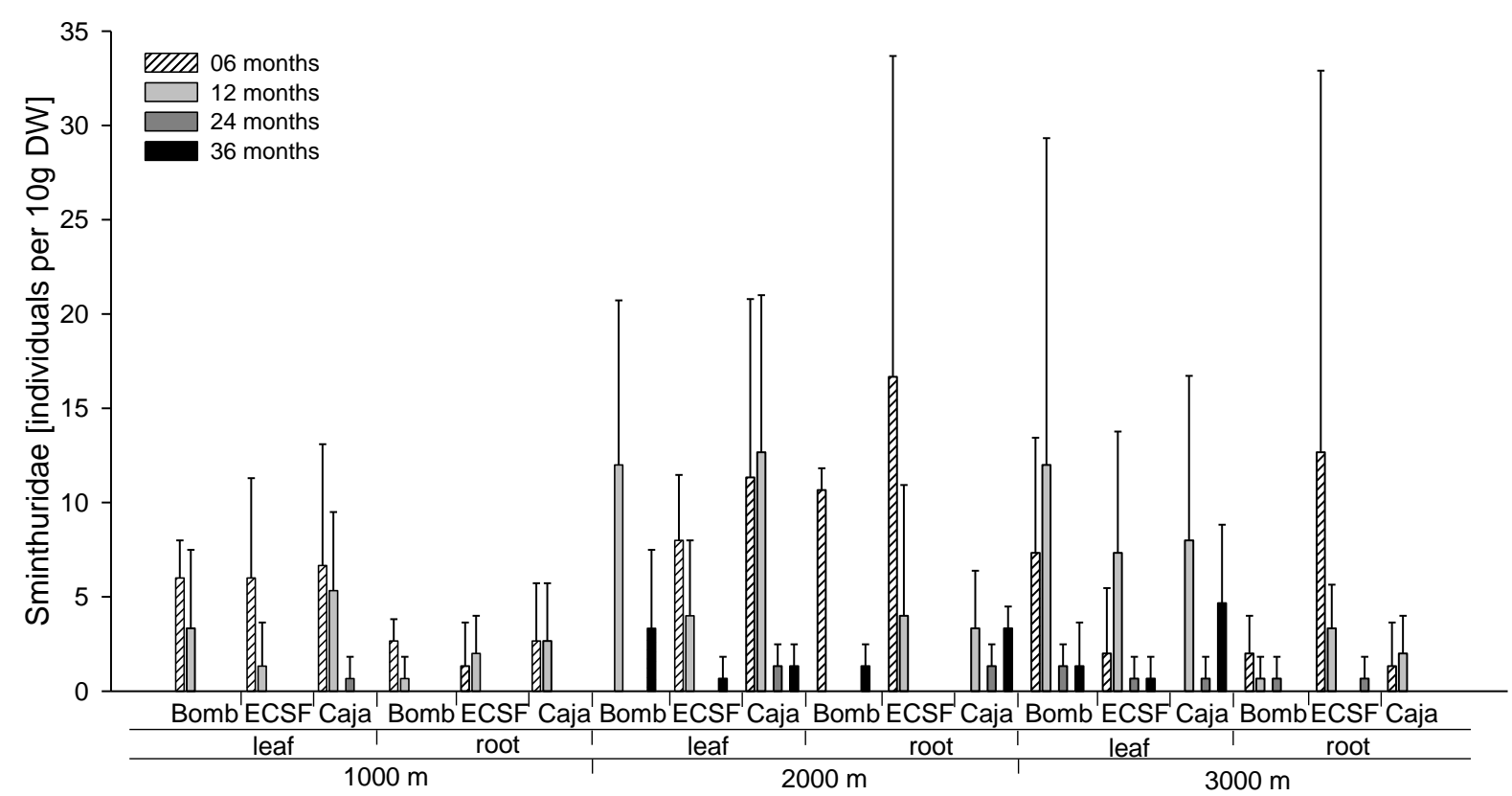

Fig. S6: Abundance of Sminthuridae leaf and root litter from three origins [Bombuscaro (Bomb), ECSF and Cajanuma (Caja)] placed at three altitudes (1000, 2000 and $3000 \mathrm{~m}$ ) and exposed in tropical montane rainforests for $6,12,24$ and 36 months (means \pm SD).

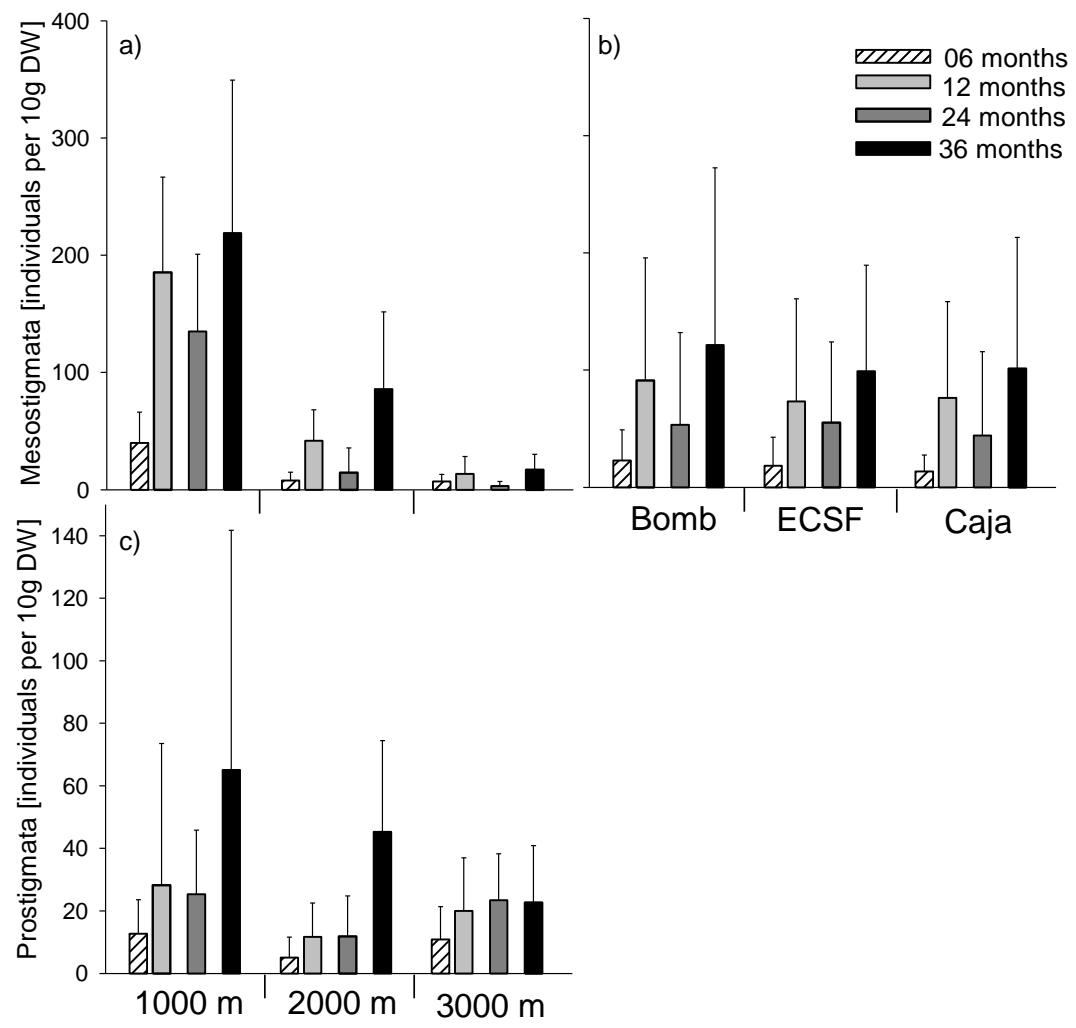

Fig. S7: Abundance Mesostigmata ( $a$ and b) and Prostigmata (c) in litter placed at three altitudes (1000, 2000 and $3000 \mathrm{~m}$ ) ( $\mathrm{a}$ and $\mathrm{c}$ ) and from three origins [Bombuscaro (Bomb), ECSF and Cajanuma (Caja)] exposed in tropical montane rainforests for 6, 12, 24 and 36 months (means \pm SD). 
Species list: List of species names (SN) and lead author, abbreviation of species name (used in Fig. 4), species number according to internal classification system (Nr.), total abundance and abundance at the three investigated altitudes (1000, 2000 and $3000 \mathrm{~m}$ ). Mode of reproduction ( $\mathrm{rm}$ ) (s = sexual, p = parthenogenetic).

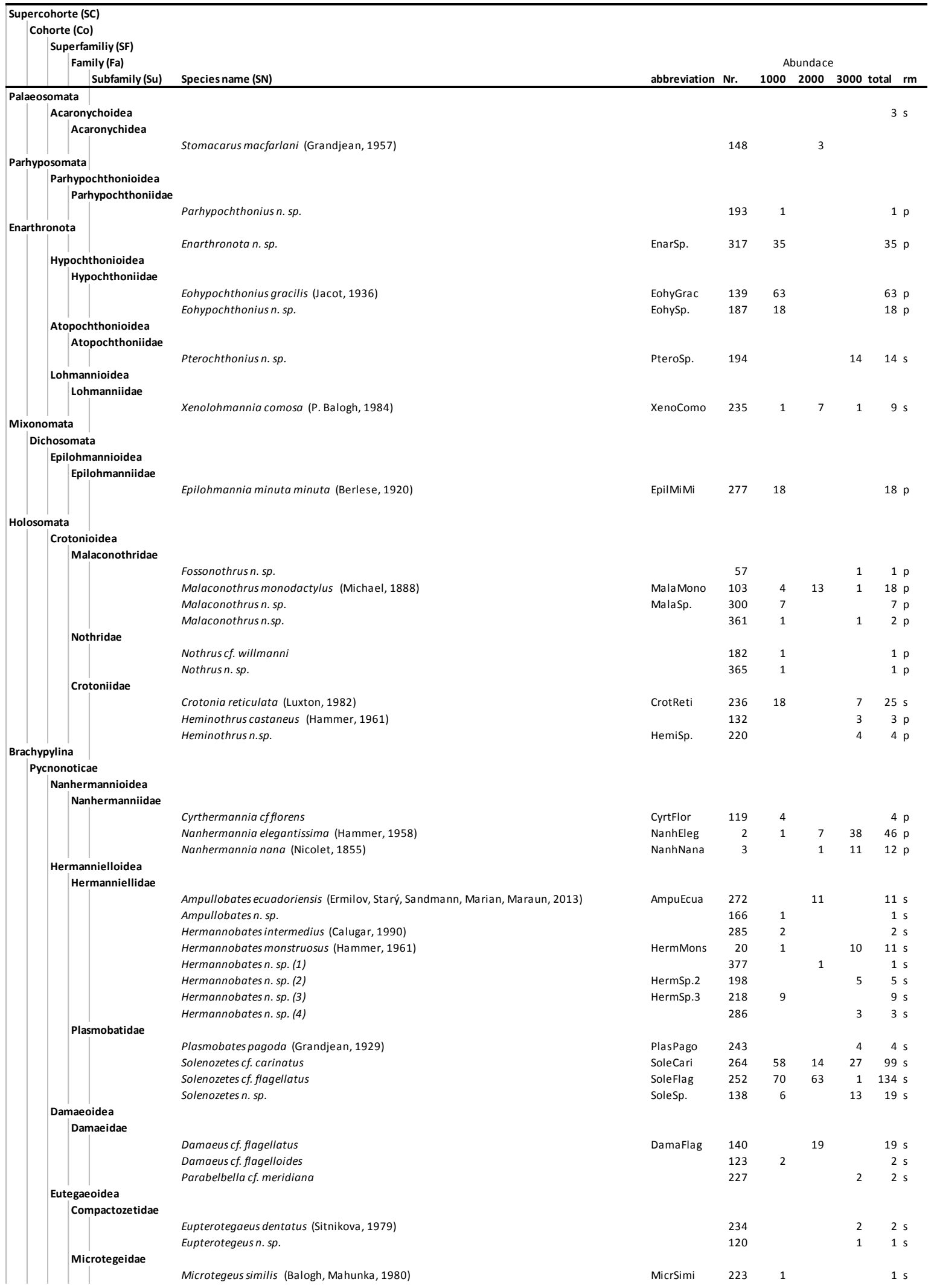


SC Co SF Fa Su

Microzetoidea

Microzetidae

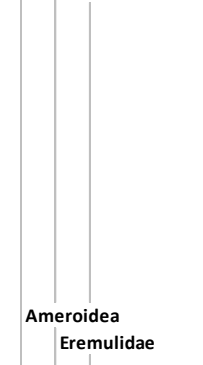

Eremulidae

Eremobelbidae

Damaeolidae

Heterobelbidae

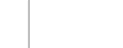

Caleremaeidae

Rhynchoribatidae

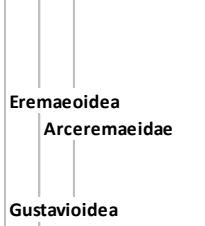

Gustavioidea

Astegestidae

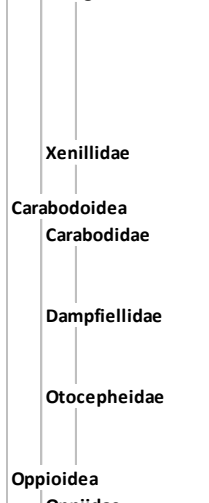

Oppiidae

Lanceoppiinae

Globoppia cf. maior
Globoppia n. sp.
Lanzeoppia cf zicsica

Chaviniinae

Oppiinae

Chavinia n. sp.

Lasiobelba chistyakovi (Ermilov, Kaluz, 2012)

Neoamerioppia longiclava (Hammer, 1962)

Neoamerioppia longicoma (Hammer, 1958)

Neoamerioppia rotunda (Hammer, 1958)

Multioppiinae

Ramusella cf. puertomonttensis

Arcoppiinae

Arcoppia dechambrierorum (Mahunka, 1983)

Kokoppia euramosa (Balogh, Mahunka, 1969)

Wallworkoppia machadoi (Balogh, Mahunka, 1958)

Brachioppiinae

Brachioppia cf. deliciosa

Brachioppian. sp. (1)

Brachioppia n. sp. (2)

Brachioppia n. sp. (3)

Brachioppiella n. sp.

Gittella n. sp.

Gittella variabilis (Ermilov, Sandmann, Marian, Maraun, 2013)

Gittella variabilis (Ermilov, Sandmann, Marian, Maraun, 2013)

abbreviation Nr. 100020003000 total rm

$\begin{array}{lrrrrr} & 159 & 3 & & \\ & 184 & 3 & & \\ & 216 & 3 & & & \\ \text { CosmSp. } & 261 & 9 & 2 & & 11 \\ \text { CosmReti } & 93 & 79 & 67 & & 146 \\ \text { LicnGran } & 153 & 33 & & & 33 \\ \text { OrthBide } & 158 & 35 & & 9 & 4 \\ & 289 & 1 & 1 & & \\ & 152 & & 6 & & \\ \text { SchaBrev } & 97 & 1 & 4 & & \\ \text { SchaPect } & 215 & 27 & 4 & & 31\end{array}$

$\begin{array}{rrrrr} & 237 & 1 & 2 & 3 p \\ \text { EremRigi } & 253 & 12 & 9 & 21 \mathrm{p}\end{array}$

$210 \quad 3 \mathrm{~s}$

$\begin{array}{lllll}\text { CaudPeta } & 171 & 16 & 5 & 21 \text { s }\end{array}$

$\begin{array}{llll}\text { Fosslaci } & 94 & 30 & 30\end{array}$

HaplSimp $296 \quad 12 \quad 12$ s

$\begin{array}{llll}\text { HeteOxap } & 244 & 16 & 16 \text { s }\end{array}$

$\begin{array}{lll}219 & 1 & 1 \mathrm{~s}\end{array}$

$\begin{array}{rrr}232 & 1 & 1\end{array}$

$\begin{array}{llllll}\text { RhynMiru } & 246 & 14 & 7 & 4 & 25\end{array}$

$\begin{array}{lllll}\text { RhynSp. } & 192 & 3 & 1 & 4 \text { s }\end{array}$

$\begin{array}{rrrr}192 & 3 & 1 & 4 \\ 211 & 2 & & 2\end{array}$

$\begin{array}{llll}\text { TectCorn } & 295 & 24 & 24 \text { s }\end{array}$

$\begin{array}{llll}\text { TectInco } & 162 & 15 & 15\end{array}$

$\begin{array}{rrrrr} & 137 & 1 & 1 & 2 \\ \text { CeraGlob } & 125 & 2 & 11 & 13\end{array}$

$\begin{array}{llll}\text { CeraSp. } & 280 & 19 & \\ & & \end{array}$

$124-11 \quad 1$ s 12

$\begin{array}{llllll}\text { CultZics } & 273 & 15 & 51 & & 66\end{array}$

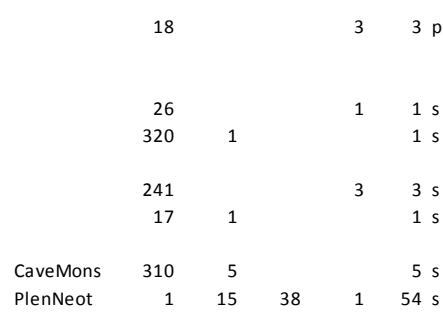

$\begin{array}{lllllr}\text { PlenNeot } & 1 & 15 & 38 & 1 & 54\end{array}$

$\begin{array}{lrrrrr} & 4 & 2 & & & 2 \mathrm{~s} \\ & 325 & 2 & & & 2 \mathrm{~s} \\ & 149 & & 4 & & 4 \mathrm{~s} \\ & 334 & & & 9 & 9 \mathrm{~s} \\ & & & & & \\ \text { LasiChis } & 168 & 78 & & & 78 \mathrm{~s} \\ \text { NeoaLoCl } & 229 & & 108 & 115 & 223 \mathrm{~s} \\ \text { NeoaLoCo } & 228 & & & 14 & 14 \mathrm{~s} \\ & 226 & & & 1 & 1 \mathrm{~s} \\ & & & & & 7 \mathrm{~s} \\ & 326 & 7 & & & \\ & & & & & 16 \\ \text { ArcoDecha } & 221 & & & 16 & \mathrm{~s} \\ \text { KokoEura } & 224 & & & 13 & 13 \mathrm{~s} \\ \text { WallMach } & 146 & 1 & 5 & & 6 \mathrm{p} \\ & & & & & 17 \mathrm{~s} \\ \text { BrachDeli } & 141 & & 17 & & 13 \\ \text { BrachSp1 } & 258 & 2 & 8 & 3 & 13 \mathrm{~s} \\ \text { BrachSp2 } & 181 & 44 & 1 & 1 & 46 \mathrm{~s} \\ & 179 & & 1 & & 1 \mathrm{~s} \\ & 386 & & & 1 & 1 \mathrm{~s} \\ & 200 & 1 & & 1 & 2 \mathrm{~s} \\ \text { GittVari } & 5 & 13 & 8 & 14 & 35 \mathrm{~s} \\ & 199 & & 3 & & 3 \mathrm{~s}\end{array}$




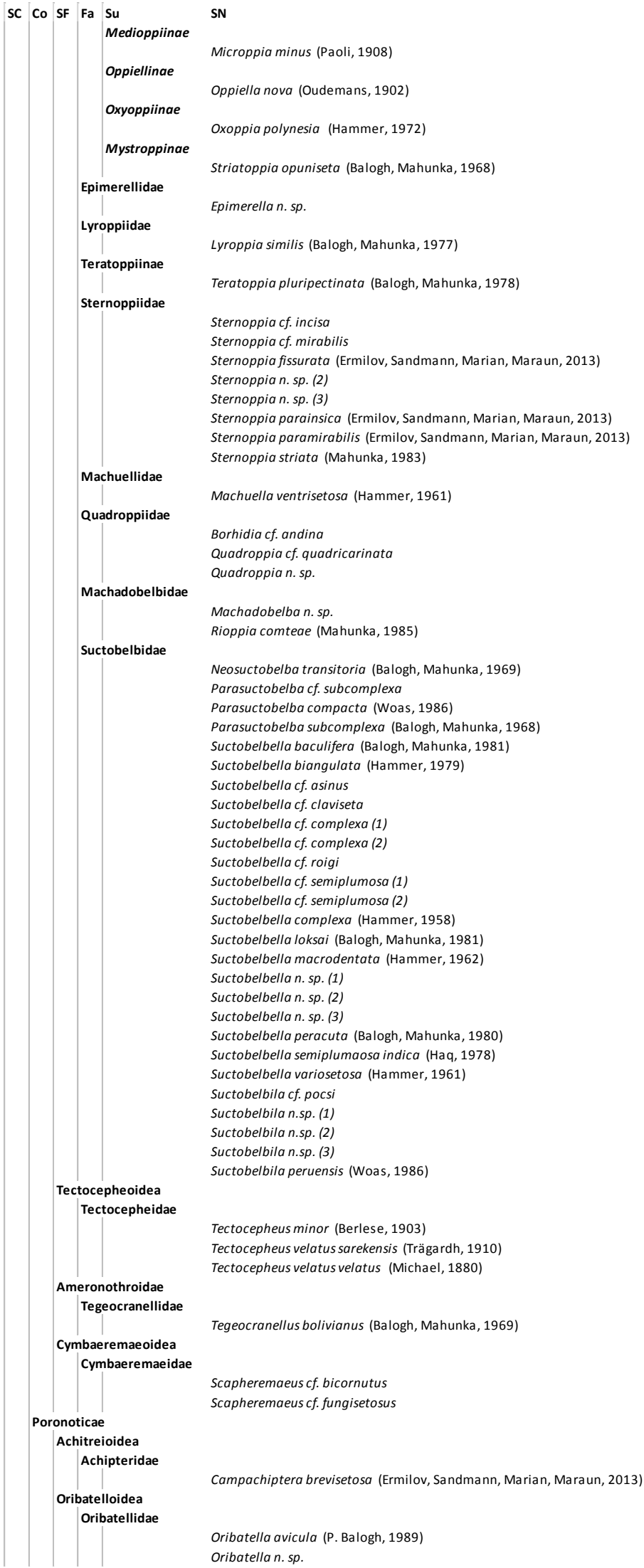

\begin{tabular}{|c|c|c|c|c|c|}
\hline \multirow[t]{2}{*}{ abbreviation } & \multirow{2}{*}{$\begin{array}{l}\text { Nr. } \\
233\end{array}$} & 1000 & \multirow[t]{2}{*}{2000} & \multicolumn{2}{|c|}{3000 total } \\
\hline & & 3 & & & 3 \\
\hline OppiNova & 13 & 158 & 88 & 18 & $264 \mathrm{p}$ \\
\hline OxopPoly & 80 & 9 & 7 & & 16 \\
\hline \multirow[t]{3}{*}{ StriOpun } & 302 & 7 & & & 7 \\
\hline & 130 & 2 & & & 2 \\
\hline & 323 & 2 & & & 2 \\
\hline TeraPlur & 142 & 10 & 14 & & 24 \\
\hline \multirow[t]{2}{*}{ SterInsi } & 59 & 12 & & 1 & $13 \mathrm{~s}$ \\
\hline & 267 & 1 & 1 & & $2 \mathrm{~s}$ \\
\hline SterFiss & 303 & 9 & 2 & & $11 \mathrm{~s}$ \\
\hline SterSp. 2 & 105 & 36 & & & $36 \mathrm{~s}$ \\
\hline SterSp. 3 & 291 & 3 & 15 & & $18 \mathrm{~s}$ \\
\hline SterPaln & 284 & 33 & 6 & & $39 \mathrm{~s}$ \\
\hline \multirow[t]{3}{*}{ SterPara } & 39 & 2 & 16 & 6 & $24 \mathrm{~s}$ \\
\hline & 84 & 1 & & & $1 \mathrm{~s}$ \\
\hline & 161 & 2 & & & $2 \mathrm{~s}$ \\
\hline \multirow[t]{4}{*}{ BorhAndi } & 231 & & & 14 & $14 \mathrm{~s}$ \\
\hline & 331 & 6 & & & $6 \mathrm{~s}$ \\
\hline & 249 & & & 1 & $1 \mathrm{~s}$ \\
\hline & 329 & 2 & & & $2 \mathrm{~s}$ \\
\hline RiopComt & 205 & 41 & & & $41 \mathrm{~s}$ \\
\hline NeosTran & 154 & 3 & 2 & & $5 p$ \\
\hline ParaSubc & 78 & 20 & 8 & & $28 \mathrm{p}$ \\
\hline ParaComp & 254 & 17 & 3 & & $20 p$ \\
\hline ParaSubc & 262 & 13 & 5 & & $18 \mathrm{p}$ \\
\hline \multirow{3}{*}{ SuctBacu } & 316 & 9 & & & $9 \mathrm{p}$ \\
\hline & 213 & & 1 & & $1 \mathrm{p}$ \\
\hline & 189 & 3 & & & $3 p$ \\
\hline SuctClav & 292 & 27 & & & $27 \mathrm{p}$ \\
\hline SuctCom1 & 263 & 61 & 8 & & $69 \mathrm{p}$ \\
\hline \multirow{2}{*}{ SuctCom2 } & 279 & 191 & 11 & & $202 p$ \\
\hline & 248 & & 1 & & $1 \mathrm{p}$ \\
\hline \multirow[t]{2}{*}{ SuctSemi } & 283 & 28 & & & $28 \mathrm{p}$ \\
\hline & 160 & 2 & & & $2 \mathrm{p}$ \\
\hline SuctComp & 308 & 68 & 26 & & $94 \mathrm{p}$ \\
\hline SuctLoks & 274 & & 11 & & $11 \mathrm{p}$ \\
\hline \multirow[t]{4}{*}{ SuctMacr } & 230 & & & 18 & $18 \mathrm{p}$ \\
\hline & 307 & 4 & & & $4 \mathrm{p}$ \\
\hline & 128 & 1 & & & $1 \mathrm{p}$ \\
\hline & 335 & 1 & & & $1 \mathrm{p}$ \\
\hline SuctPera & 86 & & 58 & 10 & $68 \mathrm{p}$ \\
\hline Suctseln & 170 & 19 & & & $19 \mathrm{p}$ \\
\hline \multirow[t]{3}{*}{ Suctvari } & 266 & 12 & & & $12 \mathrm{p}$ \\
\hline & 359 & 5 & & & $5 p$ \\
\hline & 37 & & 3 & & $3 p$ \\
\hline \multirow[t]{2}{*}{ SuBiSp. 2} & 85 & 16 & 6 & & $22 \mathrm{p}$ \\
\hline & 373 & & 5 & & $5 \mathrm{p}$ \\
\hline SuBiPeru & 203 & 18 & 1 & & 19 \\
\hline TeCeMino & 251 & 16 & 4 & & $20 p$ \\
\hline TeCeVeSa & 22 & 9 & 4 & 19 & $32 p$ \\
\hline TeCeVeVe & 77 & 20 & 85 & 29 & $134 \mathrm{p}$ \\
\hline \multirow[t]{3}{*}{ TegeBoli } & 299 & 60 & & & 60 \\
\hline & 247 & & 1 & & 1 \\
\hline & 290 & 1 & & & 1 \\
\hline \multirow[t]{2}{*}{ CampBrev } & 318 & 7 & & 5 & 12 \\
\hline & 13 & 1 & & & 1 \\
\hline Oribsp. & 239 & 4 & & 8 & $12 \mathrm{~s}$ \\
\hline
\end{tabular}


Chapter 3: Changes in the structure of soil animal communities

SC Co SF Fa Su

Oripodoidea

Mochlozetidae

Hemilleiidae

Liebstadiidae

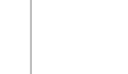

Scheloribatidae

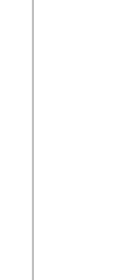

Oripodidae

Protoribatidae

Haplozetidae

Protoribatesn. sp. (1)

Protoribatesn. sp. (2)

Protoribates paracapucinus (Mahunka, 1988)

Indoribates paraminimicoma (Ermilov, Bayartogtokh, Sandmann, Marian, Maraun, 2013)

Peloribates cf. porosus

Trachyoribates carinatus

Trachyoribates glaber (Beck, 1965)

Trachyoribates n.sp. (1)

Trachyoribates n.sp. (2)

Trachyoribates n.sp. (3)

Trachyoribates n.sp. (4)

Trachyoribates n.sp. (5)

Trachyoribates ovulum ovulum (Berlese, 1908)

Trachyoribates ovulum poensis (Mihelcic, 1957) abbreviation Nr. 100020003000 total rm

\begin{tabular}{|c|c|c|c|c|c|}
\hline & 202 & & & 1 & 1 \\
\hline Hemisp. & 51 & & 18 & & \\
\hline \multirow[t]{4}{*}{ LiebSp.1 } & 147 & & 12 & & \\
\hline & 271 & 4 & & & \\
\hline & 311 & & 1 & & \\
\hline & 209 & 1 & & & \\
\hline MonoHemi & 222 & 2 & & 140 & 142 \\
\hline MonoParv & 214 & 15 & & 9 & \\
\hline \multirow[t]{2}{*}{ PersLumi } & 321 & 4 & 3 & & \\
\hline & 98 & & 2 & 1 & \\
\hline PersPara & 242 & & 3 & 10 & \\
\hline PersSeti & 245 & & & 9 & \\
\hline PersSupt & 104 & 23 & & & \\
\hline \multirow[t]{6}{*}{ SchelEleg } & 19 & & 9 & 5 & \\
\hline & 301 & & & 1 & \\
\hline & 195 & & & 1 & \\
\hline & 100 & & 2 & & \\
\hline & 204 & & & 2 & \\
\hline & 134 & & & 2 & \\
\hline \multirow[t]{3}{*}{ ProtEcua } & 281 & 41 & 26 & & \\
\hline & 327 & 1 & 5 & & \\
\hline & 371 & 3 & 5 & & \\
\hline ProtPara & 278 & 101 & 1 & & \\
\hline \multirow[t]{2}{*}{ IndoPara } & 183 & 16 & 4 & 7 & \\
\hline & 163 & & 1 & & \\
\hline \multirow[t]{2}{*}{ TrachCari } & 287 & 14 & & 1 & \\
\hline & 270 & 2 & & & \\
\hline TrachSp.1 & 315 & 12 & 1 & & \\
\hline TrachSp.2 & 293 & 22 & & 10 & \\
\hline TrachSp.3 & 376 & 13 & & & \\
\hline TrachSp.4 & 319 & 7 & 1 & & \\
\hline TrachSp.5 & 212 & 23 & & 2 & \\
\hline TrachOvOv & 9 & 72 & 112 & 3 & \\
\hline TrachOvPo & 225 & & & 51 & \\
\hline
\end{tabular}




\section{Chapter 4}

Roots, mycorrhizal fungi and altitude as determinants of litter decomposition and soil animal communities in tropical montane rainforests
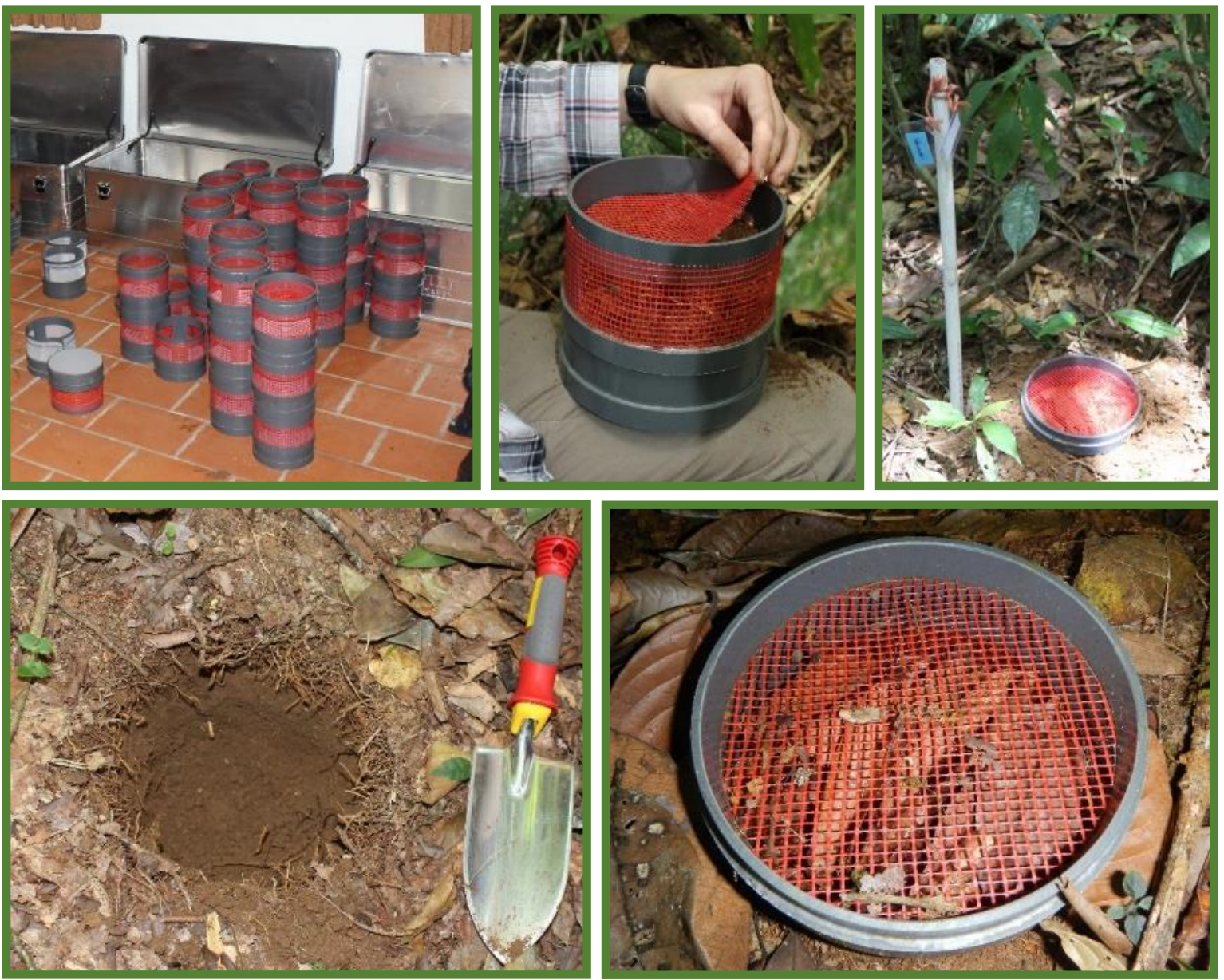

Franca Marian, Dorothee Sandmann, Linda Grevinga, Mark Maraun and Stefan Scheu 


\begin{abstract}
Roots and mycorrhizal fungi modify their surrounding soil and organic material through physical structuring, release of exudates and provision of dead organic material. We investigated the role of roots and mycorrhizal fungi on decomposition rates, microorganisms and soil microarthropods in a tropical montane rainforest in southern Ecuador. At three altitudes (1000, 2000 and 3000 m a.s.l.) microcosms with openings covered with different mesh sizes $(4 \mathrm{~mm}, 45 \mu \mathrm{m})$ or closed were exposed in the field to manipulate accessibility by roots and mycorrhizal fungi. The microcosms contained undisturbed soil with the litter layer being replaced by litter from three abundant tree species at each altitude. After 12 months water content and microbial biomass in both litter and soil, as well as the remaining amount of litter, its $\mathrm{C}$-to-N ratio and the abundance of soil microarthropods and diversity of Oribatida in the litter layer were analysed.

Decomposition rates, C-to-N ratio, water content, microbial parameters and microarthropod abundance differed between the three altitudes. While water content and C-to-N ratio were lower and microbial biomass was increased in the litter layer at the lowest altitude, decomposition rate and microarthropod abundance were at a maximum at the intermediate altitude. The exclusion of roots and mycorrhizal fungi did not affect the decomposition rate but lead to a decrease in Oribatida abundance and diversity, while Collembola abundance was increased in closed microcosms. Oribatida community composition varied between the altitudes and only few species were associated with the root and mycorrhizal exclusion treatments.

The results indicate that root- and mycorrhiza-derived resources are of similar importance at each of the three investigated altitudes. Nutrient limitation presumably resulted in competition between mycorrhizal fungi and saprotrophic microorganisms for litter-derived resources, with mycorrhizal fungi suppressing the activity of saprotrophic microorganisms. Oribatida appear to strongly depend on root-derived resources, while Collembola presumably benefitted from reduced competition between mycorrhizal fungi and saprotrophic microorganisms. Variations between the altitudes suggest that in the studied tropical montane forest ecosystem seasonality plays a larger role in structuring belowground communities than previously assumed.
\end{abstract}




\section{Introduction}

Plants affect the belowground food web through direct input of litter material as well as through the input of root exudates and via allocating carbon to mycorrhizal fungi (Hobbie, 1992; Scheu \& Setälä, 2002; Wardle et al., 2004). Over 90 \% of plant assimilated carbon ultimately enters the soil (McNaughton et al., 1989; Bardgett et al., 2005) of which 5 - 10 \% enters the soil via roots (Farrar et al., 2003). Roots modify the surrounding soil and organic material through physical structuring, release of exudates and provision of dead organic material (Bardgett, 2005; Cesarz et al., 2013; Eissfeller et al., 2013). Root exudates represent high quality resources fuelling the microbial community in the rhizosphere (Bais et al., 2006; Dennis et al., 2010). Root derived resources play an important role in increasing the activity of saprotrophic bacteria and fungi, leading to higher abundance of bacterial and fungal feeding animals, such as nematodes, protozoa and higher trophic level consumers (Bais et al., 2006; Eissfeller et al., 2013; Zieger et al., 2015). Additional carbon is transferred from plants to mycorrhizal fungi (Farrar et al., 2003), which function as a sink for plant carbon (Averill et al., 2014). In return plants receive nitrogen (N) as well as phosphorus (P) from mycorrhizal fungi with the transfer being highest in nutrient limited ecosystems (Johnson et al., 2003). Both ecto- (EM) and arbuscular-mycorrhizal (AM) fungi influence decomposition processes (Gadgil \& Gadgil, 1971; Hodge et al., 2001; Bending, 2003; Nuccio et al., 2013; Leifheit et al., 2015), and the activity and community structure of saprotrophic microorganisms (Leigh et al., 2011). Depending on environmental conditions, they may slow down or enhance litter decomposition (Gadgil \& Gadgil, 1971; Olsson et al., 1996; Hodge et al., 2001; Hodge \& Fitter, 2010), with reduced decomposition presumably being due to mycorrhizal fungi competing with saprotrophic bacteria and fungi for nutrients (mainly N; Gadgil and Gadgil, 1971; Leigh et al., 2011) as well as water (Bending, 2003).

The tropical Andes are one of the world's biodiversity hotspots (Myers et al., 2000; Brehm et al., 2008) with exceptionally high numbers of aboveground animal and plant species (Henderson et al., 1991; Myers et al., 2000; Barthlott et al., 2005). In an area with such high plant diversity the interactions between the above- and belowground system are expected to be complex. Decomposition processes in tropical montane rainforests are generally slow compared to lowland rainforests (Tanner, 1981; Heneghan et al., 1999; Illig et al., 2008; Butenschoen et al., 2014). With increasing altitude litter decomposition slows down and soil organic matter as well as soil $\mathrm{C}$ stocks increase (Wilcke et al., 2002; Leuschner et al., 2007; Illig et al., 2008). These altitudinal variations are associated with changes in plant community composition (Paulsch et al., 2006; Moser et al., 2007; Wilcke et al., 2008; Homeier et al., 2010) and an increase in fine root biomass with altitude (Kitayama \& Aiba, 2002; Leuschner et al., 2007). In particular at high altitude root biomass is concentrated in the upper organic layer rather than in mineral soil layers (Röderstein et al., 2005). 
Since the bedrock in the tropical Andes is geologically old and heavily weathered (Paulsch et al., 2006) forests typically are co-limited by both $P$ and $N$ (Homeier et al., 2012), and both soil biota and plants heavily depend on nutrients accumulated in organic layers. As indicated by high nutrient-tocarbon ratios, litter quality in organic layers is low and decreases with increasing altitude (Leuschner et al., 2007). For capturing nutrients, plants therefore are interacting closely with the soil food web including mycorrhizal fungi, saprotrophic microorganisms and soil microarthropods (F. Marian, unpublished data; Chapter 2 and 3), and presumably heavily invest into these interactions by allocating carbon to roots and root exudates.

The mycorrhizal community in Andean montane rainforests of southern Ecuador is dominated by AM fungi (Kottke et al., 2004) with only few species forming associations with EM or with both AM and EM fungi (Haug et al., 2004; Kottke et al., 2004). AM fungi not only transfer P, but also considerable amounts of $\mathrm{N}$ to their host plant (Hodge et al., 2001; Leigh et al., 2009; Veresoglou et al., 2012). However, contrasting the saprotrophic capabilities of EM and ericoid mycorrhizal fungi, AM fungi are assumed to be unable to take up organic forms of $N$, but this remains controversial (Hodge et al., 2001; Hodge \& Fitter, 2010). AM fungi have also been shown to form close interactions with the soil fauna community, e.g. the microbial community and protozoans, increasing $N$ uptake of plants via the microbial loop (Vohník et al., 2011; Koller et al., 2013) as well as soil microarthropods grazing on extra-radical hyphae of AM fungi (Gange, 2000; Johnson et al., 2005).

Soil microarthropods in tropical montane rainforests have been little studied, but their abundance is low compared to temperate forests and decreases with increasing altitude (F. Marian, unpublished data, Chapter 3; Illig et al., 2010; Rillig et al., 2013). Illig at al. (2005) described a lack of primary decomposers directly feeding on the litter material in rainforests of the Ecuadorian Andes. This lack of primary decomposers may indicate that, similar to temperate forest ecosystems (Pollierer et al., 2007, 2012) root derived resources are more important for fuelling soil microarthropod communities than previously assumed. Soil microarthropods benefit from rootderived resources either by directly feeding on roots, root exudates and mycorrhizal fungi or by feeding on free-living microorganisms which incorporate root-derived resources. The most abundant and diverse soil microarthropod group in tropical rainforests are Oribatida (Heneghan et al., 1999; Franklin et al., 2004). Species of this group not only feed on dead organic material, but also on fungi and bacteria (Maraun et al., 2003; Schneider et al., 2004; Illig et al., 2005). Their diversity in Andean montane forests is similar to that of temperate forests (Maraun et al., 2007), but they are less well studied in particular in respect to their food resources and position within the soil food web (Ermilov et al., 2013a,b,c). 
In order to assess the importance of root- and mycorrhiza-derived resources for decomposition processes and as food resources for the microarthropod community along an altitudinal gradient in a tropical montane rainforest in southern Ecuador, decomposition rates, litter quality, microorganisms as well as soil microarthropod abundance with a focus on Oribatida were investigated by experimentally excluding roots and mycorrhizal hyphae. We expected (1) roots and mycorrhiza to influence decomposition processes by competing with saprotrophic microorganisms, with reduced competition by exclusion of roots and mycorrhiza resulting in increased activity of saprotrophic microorganisms and litter decomposition. Assuming that soil microarthropods largely depend on root derived resources we expected (2) numbers of microarthropods to decline if roots and mycorrhizal hyphae are excluded. Further, we expected (3) the community structure of Oribatida species to change if roots and mycorrhizal hyphae are excluded with species depending on saprotrophic microorganisms and litter derived resources to gain in dominance. Finally, due to the decline in litter quality we expected (5) these effects to become more prominent with increasing altitude.

\section{Material and methods}

\section{Study site}

The study area with three study sites at different altitudes, 1000, 2000 and $3000 \mathrm{~m}$ a.s.l., is located in southern Ecuador on the eastern slope of the Andes within the northern part of the Podocarpus National Park in the political region of Zamora Chinchipe. The site at $1000 \mathrm{~m}$ (Bombuscaro, S04 $4^{\circ} 06^{\prime} 54^{\prime \prime}, \mathrm{W} 78^{\circ} 58^{\prime} 02^{\prime \prime}$ ) is located south of the city of Zamora in the valley of the Rio Bombuscaro. The site at $2000 \mathrm{~m}\left(\mathrm{ECSF}, \mathrm{S} 3^{\circ} 58^{\prime} 18^{\prime \prime}, \mathrm{W} 79^{\circ} 4^{\prime} 45^{\prime \prime}\right)$ is part of the Reserva Biologica San Francisco, a private reserve on the northern border of the Podocarpus National Park, which includes an area of 9 ha on the flank of the valley of the Rio San Francisco. The third site at $3000 \mathrm{~m}$ (Cajanuma, S04 ${ }^{\circ} 06^{\prime} 711^{\prime \prime}$, W79 $10^{\prime} 58^{\prime \prime}$ ) is located south of the regional capital Loja at the north-west gate of the Podocarpus National Park. All study sites face northeast to northwest, and the slopes are moderately steep between $26^{\circ}-31^{\circ}$ (Moser et al., 2007).

The region has a semi-humid climate with 8-10 humid months per year. Mean annual rainfall increases from 2230 and $1950 \mathrm{~mm}$ at 1000 and $2000 \mathrm{~m}$, respectively, to $4500 \mathrm{~mm}$ at $3000 \mathrm{~m}$ (Moser et al., 2007), while the mean annual air temperature gradually decreases from 19.4 over 15.7 to $9.4^{\circ} \mathrm{C}$ at 1000,2000 and $3000 \mathrm{~m}$, respectively. Soil pH also gradually decreases from 3.94 over 3.52 to 2.86 at 1000, 2000 and $3000 \mathrm{~m}$, respectively (Moser et al., 2007). Biotic conditions also change along the altitudinal gradient. Mean tree height decreases from 15.6 to 10.1 to $5.2 \mathrm{~m}$ at 1000,2000 and $3000 \mathrm{~m}$, respectively, while thickness of organic layers as well as fine root biomass increases from $48 \mathrm{~mm}$ and $2.7 \mathrm{t} \mathrm{ha}^{-1}$ at $1000 \mathrm{~m}$, over $305 \mathrm{~mm}$ and $6.2 \mathrm{t} \mathrm{ha} \mathrm{a}^{-1}$ at $2000 \mathrm{~m}$ to $435 \mathrm{~mm}$ and 
$10.8 \mathrm{t} \mathrm{ha}^{-1}$ at $3000 \mathrm{~m}$ (Moser et al., 2007; Graefe et al., 2008). Soil types at 1000, 2000 and $3000 \mathrm{~m}$ are predominantly Alumic Acrisols, Gley Cambisols and Podzols, respectively (Moser et al., 2007). At $1000 \mathrm{~m}$ the litter layer overlays the mineral soil (Ah horizon), i.e. $\mathrm{F}$ and $\mathrm{H}$ layers are lacking; in contrast, at 2000 and $3000 \mathrm{~m}$ the leaf litter overlays organic layers comprising predominantly of $\mathrm{F}$ material.

\section{Experimental set up}

To investigate the influence of roots and mycorrhiza on the animal community and decomposition processes, three types of mesh ingrowth core microcosms were built. Microcosms were constructed from plastic tubes $20 \mathrm{~cm}$ in length and of a diameter of $15 \mathrm{~cm}$ equipped with two windows at the side (Fig. 1a). To limit accessibility by roots and/or mycorrhiza the windows were covered with mesh of different sizes (Fig. 1b). Mesh of $4 \mathrm{~mm}$ mesh size was used to allow access of roots and mycorrhiza, i.e. to simulate natural conditions. Mesh of $45 \mu \mathrm{m}$ mesh size was used to exclude fine roots but allow access by mycorrhizal hyphae; at the study sites the diameter of fine roots varies from 0.55 to $0.68 \mathrm{~mm}$ (Graefe et al., 2008), whereas mycorrhizal hyphae typically are $<5 \mu \mathrm{m}$ (Friese \& Allen, 1991; Smith \& Read, 2008). Microcosms with the windows closed were used to exclude both roots and mycorrhizal hyphae (Fig. 1b). To allow drainage of water, but block ingrowth of roots and mycorrhizal hyphae from the bottom the cores were equipped with a double floor each consisting of $45 \mu \mathrm{m}$ mesh separated by $5 \mathrm{~cm}$ of open space.

a)

b)

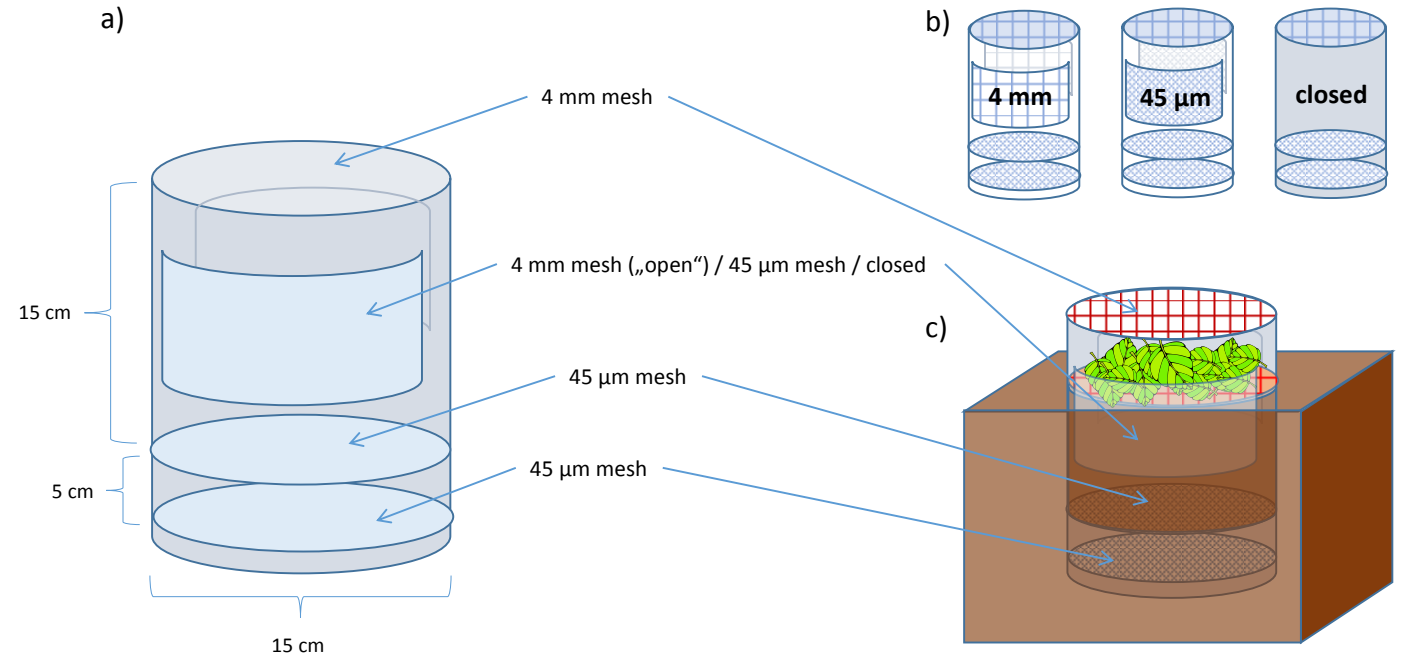

Fig. 1: Schematic depiction of the general structure of root and mycorrhiza exclusion containers (a), three types of containers with different mesh sizes in the side windows (b) and microcosm located in the soil with soil core and litter material (c).

Microcosms were placed in the field following a complete randomized block design with six blocks at each altitude spaced by at least $10 \mathrm{~m}$. Each block contained three microcosms of each mesh size, resulting in 54 microcosms in total (Fig. 2). 


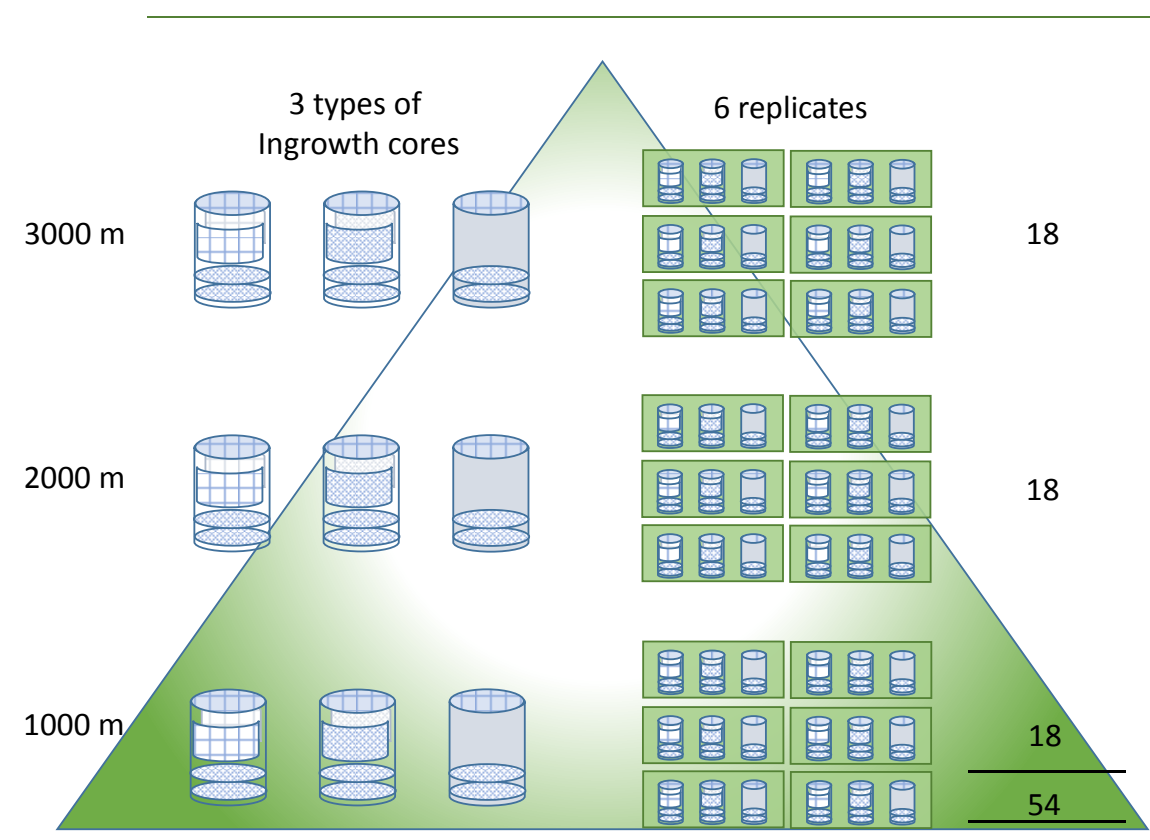

Fig. 2: Experimental design on the three altitudes (1000, 2000 and $3000 \mathrm{~m}$ ) and amount of total replicates. Schematic depiction of the microcosm types placed in the field (see Fig. 1).

Microcosms were placed into holes excavated by a steel core matching the outer diameter of the microcosms (Fig. 1c). The excavated soil was kept intact and the surrounding soil was left as undisturbed as possible. The litter layer of the excavated core was removed and the underlying $10 \mathrm{~cm}$ of the core consisting of Ah (1000 m) and F layer material (2000 and $3000 \mathrm{~m}$ ) was placed into the microcosms. We refer to this material as "soil" later in text. Separated by a $4 \mathrm{~mm}$ mesh screen, leaf litter material ("leaf litter" or "litter" later in text) was placed on top of this layer (Fig. 1c). The amount of leaf litter material added was equivalent to that in the L layer of the respective forest that had been removed from the cores and consisted of a mixture of the three most abundant tree species at the respective study sites with the proportions of the species resembling that in the respective L layer (Table 1 ).

Table 1: Leaf litter species placed into the exclusion containers and the amount of each used (g dry weight) from the three studied altitudes. The amount and proportion of the litter species placed into the exclusion containers was based on the amount and proportion of the three species present and the thickness of the litter layer at the respective study site.

\begin{tabular}{lc}
\hline Leaf species & [g] \\
\hline At $\mathbf{1 0 0 0} \mathbf{~ m}$ & 5 \\
\hline Puteria sp. & 3 \\
Cecropia andina & 2 \\
Mollinedia sp. & \\
\hline At $\mathbf{2 0 0 0} \mathbf{~}$ & 10 \\
\hline Graffenrieda emarginata & 6 \\
Clusia spp. & 4 \\
Cavendishia zamorensis & \\
\hline At $\mathbf{3 0 0 0} \mathrm{m}$ & 10 \\
\hline Clusia spp. & 8 \\
Graffenrieda emarginata & 2 \\
Hediosmum sp. &
\end{tabular}


The leaf litter material consisted of freshly fallen leaves which had been sampled in the field and dried at $60^{\circ} \mathrm{C}$ for $72 \mathrm{~h}$ prior to placement in the microcosms. Microcosms were closed by a lid of $4 \mathrm{~mm}$ mesh allowing percolation of water. Microcosms were placed into the soil with matching leaf litter layer inside and outside the microcosms. Microcosms were left in the field for 12 months. Replacement of the leaf litter layer by standardized leaf litter material allowed following decomposition of leaf litter during exposure. We focus on the colonization of the leaf litter layer by microorganisms and soil animals as microbial biomass and density of soil invertebrates is at a maximum in leaf litter at the study sites (Röderstein et al., 2005; Maraun et al., 2008; Krashevska et al., 2008).

\section{Analytical procedures}

After retrieval of the microcosms, a subsample of the litter and soil material was stored at $4^{\circ} \mathrm{C}$ and transported to Germany. Litter material was cleaned by removing soil, plants and roots and then dried at $60^{\circ} \mathrm{C}$ for four days. Litter dry mass was measured gravimetrically. For measuring $\mathrm{C}$ and $\mathrm{N}$ concentrations an aliquot of the litter material and a subsample of soil were milled to powder and 3-4 mg from each sample were filled in tin capsules and analysed using an elemental analyser (Vario EL III, elemental, Hanau, Germany).

Microbial respiration and substrate-induced respiration (SIR) were determined by measuring $\mathrm{O}_{2}$ consumption using a computer controlled $\mathrm{O}_{2}$ microcompensation apparatus (Scheu, 1992). Material of litter and soil from each microcosm was cut into pieces of about $0.5 \mathrm{~cm}^{2}$, homogenised, water content was adjusted to about $60 \%$ of the water holding capacity and the samples were rested for four days at room temperature. Then, $\mathrm{O}_{2}$ consumption was measured for $24 \mathrm{~h}$. Microbial biomass was determined by measuring SIR (Anderson \& Domsch, 1978). Moist samples equivalent to $0.2 \mathrm{~g}$ dry weight were supplemented with glucose equivalent to $80 \mathrm{mg} \mathrm{g}^{-1} \mathrm{dry}$ weight and the measurement of the $\mathrm{O}_{2}$ consumption continued for $24 \mathrm{~h}$. Microbial biomass was calculated from the maximum initial respiratory response (MIRR; $\mu \mathrm{O}_{2} \mathrm{~g}^{-1}$ dry mass $\mathrm{h}^{-1}$ ) as $\mathrm{C}_{\text {mic }}=38 \times$ MIRR (Beck et al., 1997; Joergensen \& Scheu, 1999).

Mobile soil fauna was extracted from the litter material via heat using modified Kempson extractors (Kempson et al., 1963). The extraction was performed directly after collection and transfer of the litter material to the laboratory. Animals extracted were stored in $70 \%$ ethanol. Most animal groups were determined to order, suborder or cohort level using Schaefer (2010) except for Collembola and Oribatida. Collembola were separated into five morphologically defined groups resembling the Collembola families Entomobryidae, Isotomidae, Sminthuridae, Hypogastruridae/Neanuridae (Hypogast/Neanu) and the genus Megalothorax, and were named accordingly. Oribatida were determined to species level except for Brachychthoniidae, Galumnidae, Mesoplophoridae, 
Phthiracaridae and Euphthiracaridae. For determination the keys of Balogh and Balogh $(1988,2002)$ and Weigmann (2006) were used. Species names and classification into families follow Subias (2015).

\section{Statistical analysis}

The percentages of litter remaining as well as $\mathrm{C}$-to- $\mathrm{N}$ ratio and microbial parameters ( $\mathrm{BR}$ and $\mathrm{C}_{\text {mic }}$ ) of both litter and soil were analysed by two factor randomized complete block multivariate analysis of variance (MANOVA) with block being nested in altitude; later block was excluded from the analysis as it was not significant. The fixed factors were altitude (1000, 2000 and $3000 \mathrm{~m}$ a.s.l.) and treatment (open, $45 \mu \mathrm{m}$ and closed microcosms). Thereafter, protected general linear models (GLMs) with the same factors as above were carried out (Scheiner \& Gurevitch, 2001). The percentage of litter remaining from each litter species was analysed for each altitude separately in a similar procedure with only treatment as fixed factor and the three litter species as dependent variables. Block was excluded as it was not significant.

The abundance of the total arthropods, total Collembola, total Oribatida, Collembola subgroups and Oribatida families as well as Oribatida species diversity in the litter layer per microcosm were analysed by two factor randomized complete block MANOVA with block being nested in altitude. The fixed factors were altitude (1000, 2000 and $3000 \mathrm{~m}$ a.s.l.) and treatment (open, $45 \mu \mathrm{m}$ and closed microcosm). Except for the diversity of Oribatida, block was excluded from the analyses as it was not significant. Thereafter GLMs with the same factors as above were carried out. Tukey's HSD test $(\alpha<0.05)$ was used to identify significant differences between means. Statistical analyses were performed using SAS (Statistical Analysis System, Version 9.3; SAS Institute Inc., Cary, NC, USA).

The relationship between groups of soil arthropods and environmental factors combined for the three altitudes were analysed using redundancy analysis (RDA) as implemented in CANOCO (Lepš \& Šmilauer, 2003) including the three treatments at each of the three altitudes as silent variables not affecting the ordination. Environmental variables included decomposition rate, $\mathrm{C}_{\text {mic }}, \mathrm{BR}$ and $\mathrm{C}$-to- $\mathrm{N}$ ratio. Oribatida species present in three or more microcosms were analysed by principal components analysis (PCA) for each of the three altitudes, including the three treatments (open, $45 \mu \mathrm{m}$ and closed microcosms) as silent variables not affecting the ordination using CANOCO (Lepš \& Šmilauer, 2003). Before the analyses data were inspected for homogeneity of variance and normal distribution. Percentage data were arcsine square root and all other data log-transformed. Means presented in text are based on non-transformed data. 


\section{Results}

\section{Litter decomposition and microorganisms}

Decomposition rates were significantly higher at $2000 \mathrm{~m}$ as compared to 1000 and $3000 \mathrm{~m}$; after 12 months $57.3 \pm 5.2 \%$ of the leaf litter material was decomposed at $2000 \mathrm{~m}$, while at 1000 and 3000 m only $46.7 \pm 11.0$ and $48.0 \pm 5.3 \%$ was decomposed, respectively $\left(F_{2 / 41}=8.2, p=0.001\right)$; in contrast to altitude, decomposition rates did not vary significantly with treatment $\left(F_{2 / 41}=1.2 p=\right.$ 0.322). Also, decomposition of the different leaf litter species at the three altitudes did not vary significantly with treatment. Only at $2000 \mathrm{~m}$ Clusia leaves in trend decomposed faster in closed $(60.5 \pm 4.7 \%$ of initial) as compared to open and $45 \mu \mathrm{m}$ microcosms ( $51.7 \pm 6.2$ and $51.7 \pm 5.7 \%$ of initial, respectively; $\left.F_{2 / 12}=2.9, p=0.096\right)$; while at $3000 \mathrm{~m}$ Hediosmum leaves in trend decomposed faster in open ( $54.4 \pm 9.5 \%$ of initial) as compared to $45 \mu \mathrm{m}$ and closed microcosms ( $77.1 \pm 16.2$ and $63.9 \pm 18.8 \%$ remaining, respectively; $\left.F_{2 / 12}=3.1 ; p=0.075\right)$.

The water content in the litter layer (percentage of dry weight) at $1000 \mathrm{~m}$ was lower with $190.2 \pm 59.1 \%$ as compared to $290.8 \pm 50.1$ and $281.2 \pm 47.5 \%$ at 2000 and $3000 \mathrm{~m}$, respectively $\left(F_{2 / 40}=22.0, p<0.001\right)$. In soil the difference was even more pronounced with only $44.8 \pm 10.4 \%$ at $1000 \mathrm{~m}$ as compared to $506.4 \pm 126.0$ and $656.5 \pm 114.7 \%$ at 2000 and $3000 \mathrm{~m}$, respectively $\left(F_{2 / 40}=\right.$ 213.7, $p=<0.001)$. In both litter and soil the water content in open microcosms was slightly but significantly lower than in $45 \mu \mathrm{m}$ and closed microcosms (litter: 227.3 $\pm 81.0,266.3 \pm 70.4$ and $268.1 \pm 44.7 \%$, respectively; $F_{2 / 40}=4.2, p=0.014$; soil: $365.1 \pm 257.6,1.4 \pm 302.0$ and $432.9 \pm 308.0 \%$, respectively; $F_{2 / 40}=4.2, p=0.022$ ).

The $\mathrm{C}$-to- $\mathrm{N}$ ratio in leaf litter increased with increasing altitude from $26.2 \pm 1.0$ to $48.1 \pm 4.4$ to $61.9 \pm 15.2$ at 1000,2000 and $3000 \mathrm{~m}$, respectively $\left(F_{2 / 41}=114.8, p<0.001\right)$. In soil the C-to-N ratio was significantly lower at $1000 \mathrm{~m}$ as compared to 2000 and $3000 \mathrm{~m}$ with $12.6 \pm 0.6$ as compared to $24.8 \pm 2.0$ and $25.3 \pm 2.7$, respectively $\left(F_{2 / 41}=347.1, p<0.001\right)$.

At $1000 \mathrm{~m}$ BR in soil was much lower than at 2000 and $3000 \mathrm{~m}(3.1 \pm 1.0,52.7 \pm 14.6$ and $58.0 \pm 19.3$ $\mu \mathrm{g} \mathrm{O}_{2} \mathrm{~g}^{-1}$ dry weight $\mathrm{h}^{-1}$ respectively; $F_{2 / 39}=458.5, \mathrm{p}<0.001$ ). Respiration in leaf litter was higher in closed $\left(87.5 \pm 21.4 \mu \mathrm{g} \mathrm{O}_{2} \mathrm{~g}^{-1}\right.$ dry weight $\left.\mathrm{h}^{-1}\right)$ as compared to the open and $45 \mu \mathrm{m}$ microcosms $\left(68.2 \pm 22.1\right.$ and $66.8 \pm 23.6 \mu \mathrm{g} \mathrm{O}_{2} \mathrm{~g}^{-1}$ dry weight $\mathrm{h}^{-1}$, respectively; $\left.\mathrm{F}_{2 / 35}=5.3, \mathrm{p}=0.010\right)$. In trend the same was true for microbial biomass with $8934 \pm 4796 \mu \mathrm{g} \mathrm{C} \mathrm{C}_{\text {mic }} \mathrm{g}^{-1}$ dry weight in closed microcosms in litter compared to $6893 \pm 1906$ and $7153 \pm 2245 \mu \mathrm{g} \mathrm{C}_{\text {mic }} \mathrm{g}^{-1} \mathrm{dry}$ weight in open and $45 \mu \mathrm{m}$ microcosms, respectively $\left(F_{2 / 35}=2.9, p=0.068\right)$. At $1000 \mathrm{~m}\left(10,324 \pm 3577 \mu \mathrm{g}_{\text {mic }} \mathrm{g}^{-1}\right.$ dry weight $)$ microbial

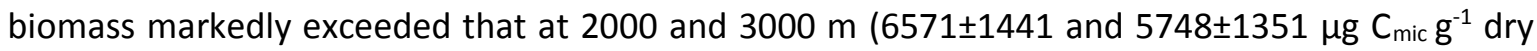
weight, respectively; $\left.F_{2 / 35}=24.4, p<0.001\right)$. However, in soil it was the opposite with microbial biomass at $1000 \mathrm{~m}\left(734.1 \pm 160.6 \mu \mathrm{g} \mathrm{C}_{\text {mic }} \mathrm{g}^{-1}\right.$ dry weight) being markedly lower than at 2000 and $3000 \mathrm{~m}\left(4521 \pm 1080\right.$ and $3969 \pm 1177 \mu \mathrm{g} C_{\text {mic }} \mathrm{g}^{-1}$ dry weight, respectively; $\left.F_{2 / 39}=185.2, \mathrm{p}<0.001\right)$. 


\section{Animals}

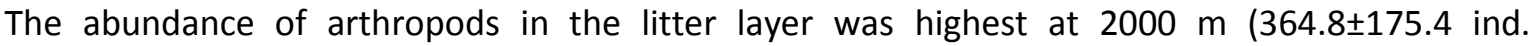
microcosm $\left.^{-1}\right)$ and lower at 1000 and $3000 \mathrm{~m}\left(206.7 \pm 93.4\right.$ and $91.5 \pm 46.9$ ind. microcosm $^{-1}$, respectively; $\left.F_{2 / 27}=24.6, p<0.001\right)$. In open microcosms the abundance of arthropods $(290.8 \pm 188.7$ ind. microcosm $\left.{ }^{-1}\right)$ exceeded that in $45 \mu \mathrm{m}$ and closed microcosms $(194.7 \pm 123.8$ and $177.5 \pm 153.9$ ind. microcosm ${ }^{-1}$, respectively; $F_{2 / 27}=5.3, p=0.012$ ).

The abundance of the two most abundant soil arthropod groups, Collembola and Oribatida, increased in each of the treatments and at each of the three altitudes from the initial density present in the undisturbed soil core to the total abundance in the soil and litter layer at the end of the experiment (Table 2). Collembola density increased from initially $8.75 \pm 6.5,38.25 \pm 17.63$ and $9.0 \pm 2.83$ at 1000,2000 and $3000 \mathrm{~m}$, respectively by $91.12 \pm 36.11,142.14 \pm 19.77$ and $186.34 \pm 69.65 \%$ in open, $45 \mu \mathrm{m}$ and closed microcosms, respectively. The abundance of Oribatida increased from initially $15.25 \pm 13.23,23.75 \pm 10.4$ and $4.75 \pm 2.06$ at 1000,2000 and $3000 \mathrm{~m}$, respectively, by $604.37 \pm 198.65,313.52 \pm 102.99$ and $141.18 \pm 78.96 \%$ in open, $45 \mu \mathrm{m}$ and closed microcosms, respectively.

Table 2: Mean abundance (mean) (ind. microcosm ${ }^{-1}$ ) and standard deviation (SD) of (a) Collembola and (b) Oribatida in undisturbed soil cores from the three investigated altitudes (1000, 2000 and $3000 \mathrm{~m}$ ) before exposure in the field (initial abundance (soil)) and in the combined soil and litter layer cores in the three different treatments (open, $45 \mu \mathrm{m}$ and closed) at the end of the experiment (end abundance (soil + litter)).

\begin{tabular}{|c|c|c|c|c|c|}
\hline \multirow[t]{2}{*}{ altitude } & \multicolumn{2}{|c|}{ initial abundace (soil) } & \multirow[t]{2}{*}{ treatment } & \multicolumn{2}{|c|}{ end abundance (soil + litter) } \\
\hline & mean & SD & & mean & SD \\
\hline \multirow[t]{3}{*}{1000} & 8.75 & 6.50 & open & 18.00 & 14.76 \\
\hline & & & $45 \mu \mathrm{m}$ & 22.00 & 13.29 \\
\hline & & & closed & 30.50 & 27.14 \\
\hline \multirow[t]{3}{*}{2000} & 38.25 & 17.63 & open & 83.25 & 35.44 \\
\hline & & & $45 \mu \mathrm{m}$ & 97.75 & 83.12 \\
\hline & & & closed & 114.50 & 50.40 \\
\hline \multirow[t]{3}{*}{3000} & 9.00 & 2.83 & open & 13.50 & 6.56 \\
\hline & & & $45 \mu \mathrm{m}$ & 19.75 & 14.15 \\
\hline & & & closed & 19.00 & 16.10 \\
\hline \multicolumn{6}{|c|}{ b) Oribatida } \\
\hline \multirow[t]{2}{*}{ altitude } & \multicolumn{2}{|c|}{ initial abundace (soil) } & treatment & \multicolumn{2}{|c|}{ end abundance (soil + litter) } \\
\hline & mean & SD & & mean & SD \\
\hline \multirow[t]{3}{*}{1000} & 15.25 & 13.23 & open & 76.00 & 42.29 \\
\hline & & & $45 \mu \mathrm{m}$ & 74.25 & 38.79 \\
\hline & & & closed & 36.50 & 18.93 \\
\hline \multirow[t]{3}{*}{2000} & 23.75 & 10.40 & open & 171.00 & 60.55 \\
\hline & & & $45 \mu \mathrm{m}$ & 70.25 & 28.91 \\
\hline & & & closed & 76.25 & 61.14 \\
\hline \multirow[t]{3}{*}{3000} & 4.75 & 2.06 & open & 42.50 & 13.70 \\
\hline & & & $45 \mu \mathrm{m}$ & 21.75 & 15.65 \\
\hline & & & closed & 7.75 & 2.22 \\
\hline
\end{tabular}


The abundance of Collembola in the litter layer along the altitudinal gradient resembled that of total arthropods $\left(\mathrm{F}_{2 / 27}=40.54 ; \mathrm{P}=<0.001\right)$, but the abundance along the altitudinal gradient also varied with treatment (altitude $\times$ treatment interaction; $F_{4 / 27}=2.97, p=0.0373$ ). At 1000 and $2000 \mathrm{~m}$ it was highest in closed microcosms $\left(29.0 \pm 22.2\right.$ and $126.5 \pm 77.5$ ind. microcosm ${ }^{-1}$, respectively) and lower in $45 \mu \mathrm{m}\left(17.0 \pm 10.1\right.$ and $79.5 \pm 107.0$ ind. microcosm ${ }^{-1}$, respectively) and open microcosms (18.5 \pm 16.9 and $90.0 \pm 36.8$ ind. microcosm ${ }^{-1}$, respectively), while at $3000 \mathrm{~m}$ the abundance was higher in open and $45 \mu \mathrm{m}$ microcosms $\left(9.0 \pm 7.7\right.$ and $6.5 \pm 3.0$ ind. microcosm ${ }^{-1}$, respectively) than in closed microcosms $\left(1.5 \pm 1.9\right.$ ind. microcosm $\left.{ }^{-1} ; F_{4 / 27}=3.0, p=0.037\right)$. The Collembola groups Hypogastruridae/Neanuridae, Isotomidae, Megalothorax and Sminthuridae were most abundant at $2000 \mathrm{~m}\left(9.8 \pm 11.8,7.8 \pm 6.7,42.3 \pm 48.9\right.$ and $29.7 \pm 31.7$ ind. microcosm ${ }^{-1}$, respectively) and less abundant at $1000\left(5.0 \pm 7.3,3.2 \pm 3.8,9.2 \pm 12.9\right.$ and $2.8 \pm 3.1$ ind. microcosm ${ }^{-1}$, respectively) and $3000 \mathrm{~m}\left(1.0 \pm 1.6,1.7 \pm 2.1,0.3 \pm 0.8\right.$ and $0.5 \pm 1.2$ ind. microcosm ${ }^{-1}$, respectively) (Table 3).

Table 3: $\mathrm{F}$ - and $\mathrm{p}$-values of Collembola morphogroups in the litter layer of microcosms exposed at three altitudes (1000, 2000 and $3000 \mathrm{~m}$ a.s.l.) and subjected to three treatments (open, $45 \mu \mathrm{m}$ and closed). (Hypogast/Neanu: Hypogastruridae and Neanuridae). Significant values are given in bold.

\begin{tabular}{lcccccccccc} 
& \multicolumn{2}{c}{ Hypogast/Neanu } & \multicolumn{2}{c}{ Isotomidae } & \multicolumn{2}{c}{ Megalothorax } & \multicolumn{2}{c}{ Sminthuridae } & \multicolumn{2}{c}{ Entomobyridae } \\
Litter & F-value & p-value & F-value & $\mathbf{p}$-value & F-value & p-value & F-value & p-value & F-value & p-value \\
\hline altitude & $\mathbf{5 . 0 8}$ & $\mathbf{0 . 0 1 3 4}$ & $\mathbf{7 . 1 6}$ & $\mathbf{0 . 0 0 3 2}$ & $\mathbf{2 8 . 8 9}$ & $<\mathbf{0 . 0 0 0 1}$ & $\mathbf{1 7 . 6 5}$ & $<\mathbf{0 . 0 0 0 1}$ & $\mathbf{4 . 5 7}$ & $\mathbf{0 . 0 1 9 6}$ \\
treatment & 0.26 & 0.7752 & 1.95 & 0.1618 & 1.81 & 0.1826 & 1.51 & 0.2382 & 0.88 & 0.4247 \\
altitude*treatment & 0.48 & 0.7535 & 1.87 & 0.1449 & 1.11 & 0.3737 & 0.54 & 0.7106 & $\mathbf{4 . 5 4}$ & $\mathbf{0 . 0 0 6 2}$ \\
\hline
\end{tabular}

The abundance of Entomobryidae varied significantly between treatments, but the effect depended on altitude (Table 3). It was highest in closed microcosms at $2000 \mathrm{~m}$, where it was more than five times higher than in any other treatment on other altitudes (Fig. 3). At $1000 \mathrm{~m}$ the abundance was highest in $45 \mu \mathrm{m}$ microcosms and at $3000 \mathrm{~m}$ it was highest in open microcosms.

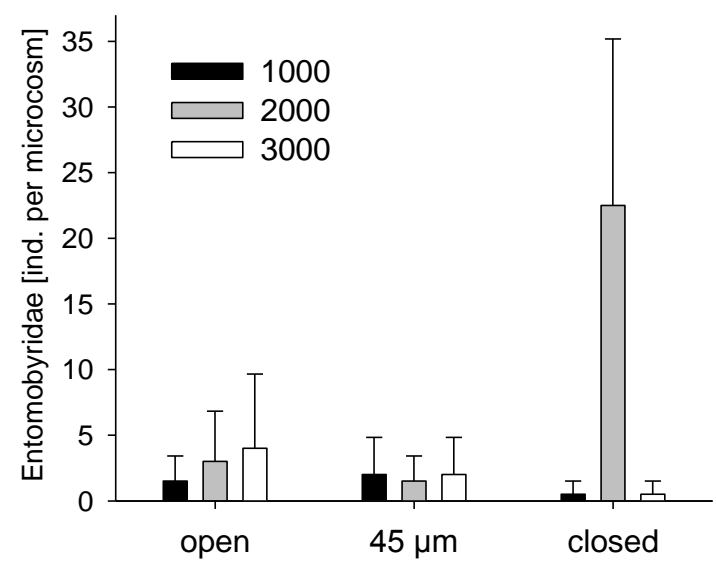

Fig. 3: Mean abundance and standard deviation of Entomobryidae in open, $45 \mu \mathrm{m}$ and closed microcosms exposed in the field at three altitudes (1000, 2000 and 3000 m a.s.I.) for 12 months (means \pm SD). 
The abundance of the three largest groups within the Acarina in the litter layer significantly varied with altitude, namely Gamasina $\left(F_{2 / 27}=16.4, p=<0.001\right)$, Uropodina $\left(F_{2 / 27}=57.9, p=<0.001\right)$ and Oribatida $\left(F_{2 / 27}=20.4, p=<0.001\right)$. Abundances also varied between treatments for Gamasina $\left(F_{2 / 27}\right.$ $=3.3, p=0.053$; fig. 4$)$ and Oribatida $\left(F_{2 / 27}=13.5, p=<0.001 ;\right.$ Fig. 4). The abundance of Gamasina and Uropodina decreased from $1000 \mathrm{~m}\left(22.7 \pm 20.2\right.$ and $19.0 \pm 9.9$ ind. microcosm ${ }^{-1}$, respectively) to

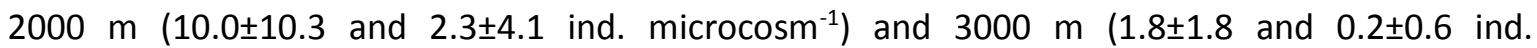
microcosm $\left.{ }^{-1}\right)$. In contrast, in Oribatida it was highest at $2000 \mathrm{~m}\left(178.3 \pm 119.9\right.$ ind. microcosm $\left.^{-1}\right)$ and lower at $1000\left(100.0 \pm 59.7\right.$ ind. microcosm $\left.{ }^{-1}\right)$ and $3000 \mathrm{~m}\left(40.3 \pm 34.5\right.$ ind. microcosm $\left.^{-1}\right)$. The abundance of both Gamasina and Oribatida was highest in open microcosms as compared to $45 \mu \mathrm{m}$ and closed microcosms (Fig. 4).
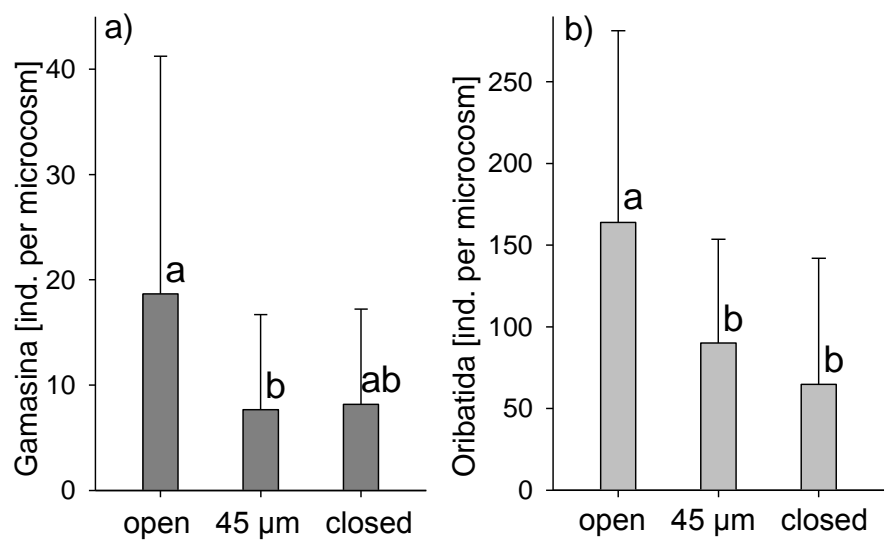

Fig. 4: Mean abundance and standard deviation of Gamasina (a) and Oribatida (b) in open, $45 \mu \mathrm{m}$ and closed microcosms exposed in the field at three altitudes (1000, 2000 and $3000 \mathrm{~m}$ a.s.l.) for 12 months (means \pm SD).

Using forward selection, two of the four explanatory variables included in the RDA were significantly related to the community structure of soil animals, i.e. C-to-N ratio and decomposition rate (Fig. 5). All four variables together explained $25.8 \%$ of the variation in animal data with the C-to-N ratio explaining $12.2 \%(F=3.9, P=0.006)$, decomposition rate $7.4 \%(F=2.5, P=0.036)$, basal respiration $3.7 \%$ and $\mathrm{C}_{\text {mic }} 2.6 \%$. Separation of the three altitudes in the RDA primarily reflected differences in animal community composition. In contrast, the three treatments were grouped close to each other. Most animal taxa were most abundant at $2000 \mathrm{~m}$ and reached low densities at $3000 \mathrm{~m}$. $\mathrm{C}_{\text {mic }}$ was associated with $1000 \mathrm{~m}$ reflecting the high microbial biomass in the litter at this altitude. Uropodina and Gamasina were associated with high $\mathrm{C}_{\text {mic }}$. High decomposition rates were associated with $2000 \mathrm{~m}$ and Collembola groups. Microcosms at $3000 \mathrm{~m}$ were associated with high C-to-N ratio and characterized by a lack of animal groups associated with this altitude. 


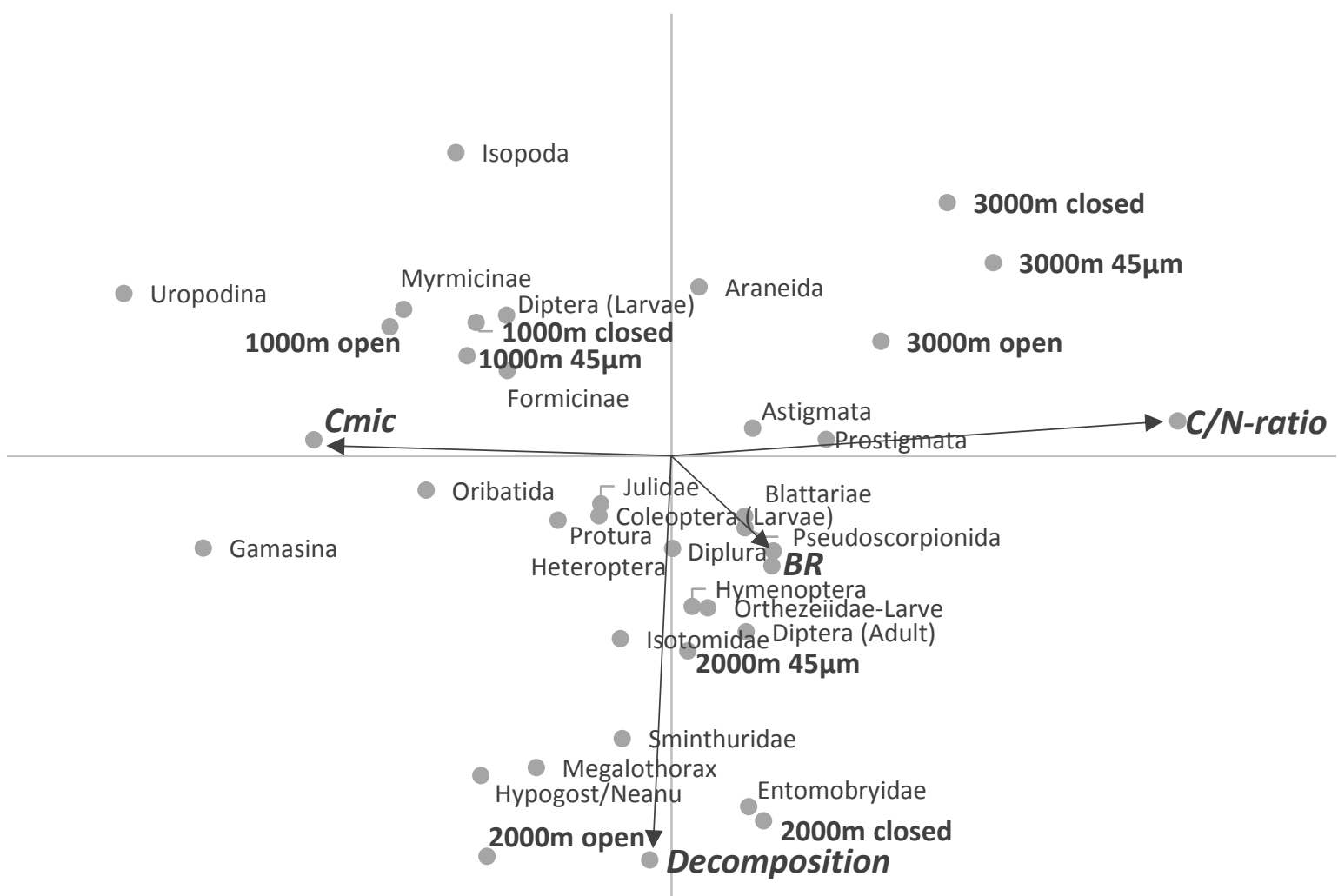

Fig. 5: Forward selection RDA of the animal groups with supplementary variables ( $\mathrm{Cmic}=$ microbial biomass; $\mathrm{BR}=$ basal respiration; $\mathrm{C} / \mathrm{N}$-ratio and decomposition (as percentage of litter decomposed after 12 months)) and altitude dummies (three altitudes (1000, 2000 and $3000 \mathrm{~m}$ a.s.l.) and three treatments (open, $45 \mu \mathrm{m}$, closed))

Oribatida groups responded in a similar way to changes in altitude as total Oribatida with the changes being significant in 14 groups (Table 4). In most groups the abundances were highest at $2000 \mathrm{~m}$ and lower at 1000 and $3000 \mathrm{~m}$ or groups were not present at these altitudes [Ameroidea $\left(1.0 \pm 2.3,3.2 \pm 5.2\right.$ and 0 ind. microcosm ${ }^{-1}$ at 1000, 2000 and $3000 \mathrm{~m}$, respectively), Damaeoidea (0, $3.2 \pm 6.2$ and 0$)$, Phthiracaroidea $(1.3 \pm 1.8,5.2 \pm 4.7$ and $1.8 \pm 3.5)$, Galumnoidea $(9.2 \pm 14.4,17.2 \pm 13.3$ and 1.8 \pm 3.2 ), Gustavioidea $(1.8 \pm 3.0,20.7 \pm 37.8$ and $0.3 \pm 0.8)$, Suctobelbidae $(7.7 \pm 7.0,8.8 \pm 13.4$ and 0 ) and Oppioidea $(9.8 \pm 8.4,55.2 \pm 40.2$ and 0$)]$. In contrast, Oripodoidea $(26.3 \pm 24.5,15.5 \pm 22.3$ and $12.7 \pm 16.2$ ind. microcosm ${ }^{-1}$ at 1000, 2000 and $3000 \mathrm{~m}$, respectively) and Hermannielloidea (2.7 $\pm 3.7,0.5 \pm 0.9$ and 0 ) were more abundant at $1000 \mathrm{~m}$ as compared to 2000 and $3000 \mathrm{~m}$. Ameronothroidae, Enarthronota and Hypochthonioidea were only present at $1000 \mathrm{~m}(1.8 \pm 2.5$, $3.3 \pm 6.3$ and $2.3 \pm 2.4$ ind. microcosm ${ }^{-1}$, respectively). 
Table 4: ANOVA table of F- and p-values on changes in the density of the 14 Oribatida subgroups in the litter layer of microcosms exposed at three altitudes (1000, 2000 and $3000 \mathrm{~m}$ a.s.l.) and subjected to three treatments (open, $45 \mu \mathrm{m}$ and closed). Significant values are given in bold.

\begin{tabular}{|c|c|c|c|c|c|c|c|c|c|c|}
\hline & \multicolumn{2}{|c|}{ Ameroidea } & \multicolumn{2}{|c|}{ Damaeoidea } & \multicolumn{2}{|c|}{ Phthiracaroidea } & \multicolumn{2}{|c|}{ Galumnoidea } & \multicolumn{2}{|c|}{ Gustavioidea } \\
\hline & F-value & p-value & F-value & p-value & F-value & p-value & F-value & p-value & F-value & p-value \\
\hline altitude & 6.52 & 0.0049 & 7.01 & 0.0035 & 4.05 & 0.0289 & 15.34 & 0 & 16.48 & 0 \\
\hline treatment & 4.38 & 0.0225 & 0.35 & 0.7046 & 2.19 & 0.1311 & 3.65 & 0.0396 & 2.19 & 0.1309 \\
\hline \multirow[t]{3}{*}{ altitude*treatment } & 1.38 & 0.2687 & 0.35 & 0.8384 & 0.61 & 0.6576 & 2.35 & 0.0798 & 0.67 & 0.6187 \\
\hline & \multicolumn{2}{|c|}{ Suctobelbidae } & \multicolumn{2}{|c|}{ Oppioidea } & \multicolumn{2}{|c|}{ Oripodoidea } & \multicolumn{2}{|c|}{ Hermannielloidea } & \multicolumn{2}{|c|}{ Ameronothridea } \\
\hline & F-value & p-value & F-value & p-value & F-value & p-value & F-value & p-value & F-value & p-value \\
\hline altitude & 20.3 & 0 & 129.64 & 0 & 3.92 & 0.0321 & 7.48 & 0.0026 & 6.3 & 0.0057 \\
\hline treatment & 3.6 & 0.041 & 1.95 & 0.1616 & 9.29 & 0.0009 & 4.27 & 0.0245 & 0.18 & 0.8348 \\
\hline \multirow[t]{3}{*}{ altitude*treatment } & 1.46 & 0.242 & 0.49 & 0.741 & 0.95 & 0.4522 & 1.95 & 0.1304 & 0.18 & 0.9458 \\
\hline & \multicolumn{2}{|c|}{ Enathronota } & \multicolumn{2}{|c|}{ Hypochthonidea } & \multicolumn{2}{|c|}{ Nanhermannioidea } & \multicolumn{2}{|c|}{ Microzetoidea } & & \\
\hline & F-value & p-value & F-value & p-value & F-value & p-value & F-value & $p$-value & & \\
\hline altitude & 6.13 & 0.0064 & 12.88 & 0.0001 & 8.93 & 0.0011 & 7.41 & 0.0027 & & \\
\hline treatment & 1.08 & 0.3526 & 0.58 & 0.5693 & 5.52 & 0.0098 & 5.09 & 0.0133 & & \\
\hline altitude*treatment & 1.08 & 0.3842 & 0.58 & 0.6829 & 2.8 & 0.0459 & 3.15 & 0.03 & & \\
\hline
\end{tabular}

Five Oribatida groups responded significantly to the treatments (Table 4; Fig. 6). Ameroidea, Oripodoidea and Suctobelbidae were more abundant in the open and less abundant in the $45 \mu \mathrm{m}$ and closed microcosms, while the abundances of Hermannielloidea and Galumnidae were similar in open and $45 \mu \mathrm{m}$ and lower in closed microcosms (Fig. 6).
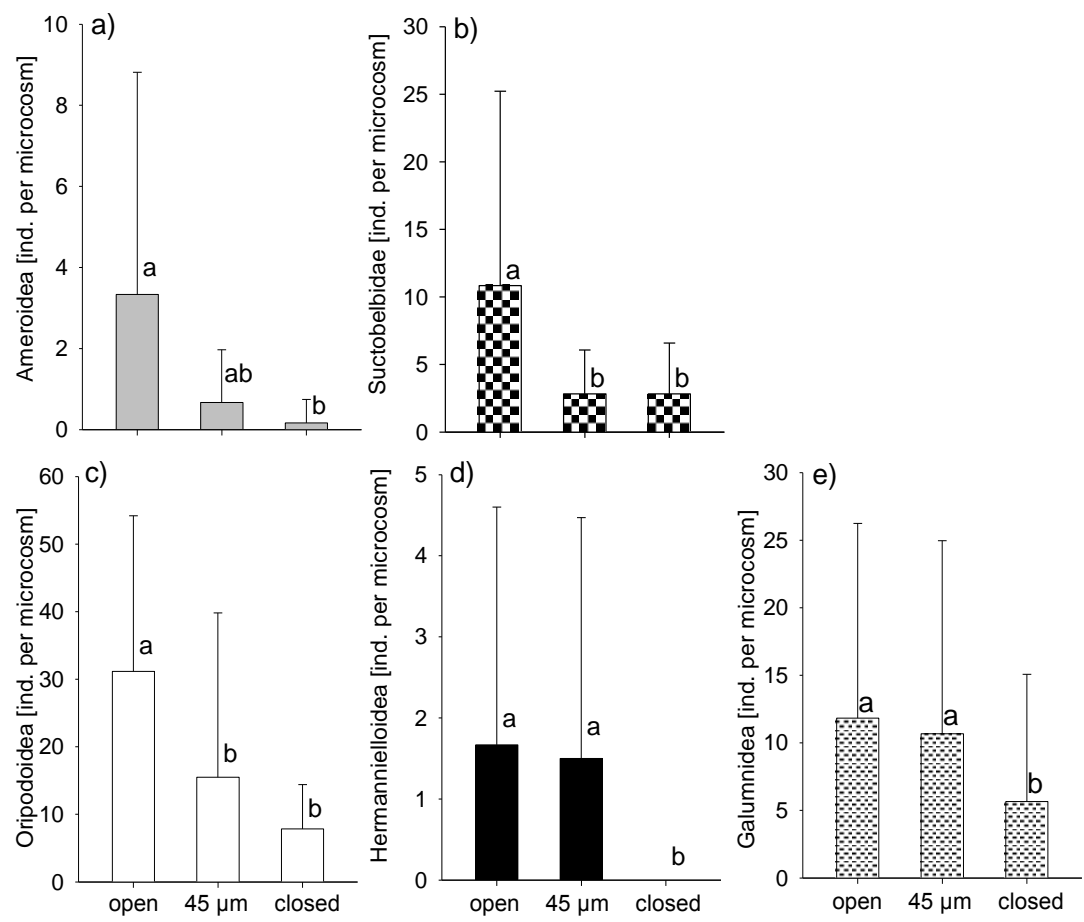

Fig. 6: Mean abundance and standard deviation of five Oribatida groups in open, $45 \mu \mathrm{m}$ and closed microcosms exposed in the field at three altitudes (1000, 2000 and $3000 \mathrm{~m}$ a.s.l.) for 12 months (means $\pm S D$ ) 
For the abundance of two Oribatida groups, the interaction between treatment and altitude was significant (Table 4). Nanhermannioidea were only found at 2000 and $3000 \mathrm{~m}$ (Fig. 7a) and at both altitudes most animals were present in open microcosms. At $2000 \mathrm{~m}$ the abundance was lowest in $45 \mu \mathrm{m}$ microcosms while at $3000 \mathrm{~m}$ it was lowest in closed microcosms. Microzetoidea were only present at 1000 and $2000 \mathrm{~m}$ (Fig. 7b). At $2000 \mathrm{~m}$ they were only present in open while at $1000 \mathrm{~m}$ they were present in open and $45 \mu \mathrm{m}$, but were most abundant in the open microcosms. At each of the altitudes no individuals were present in closed microcosms.

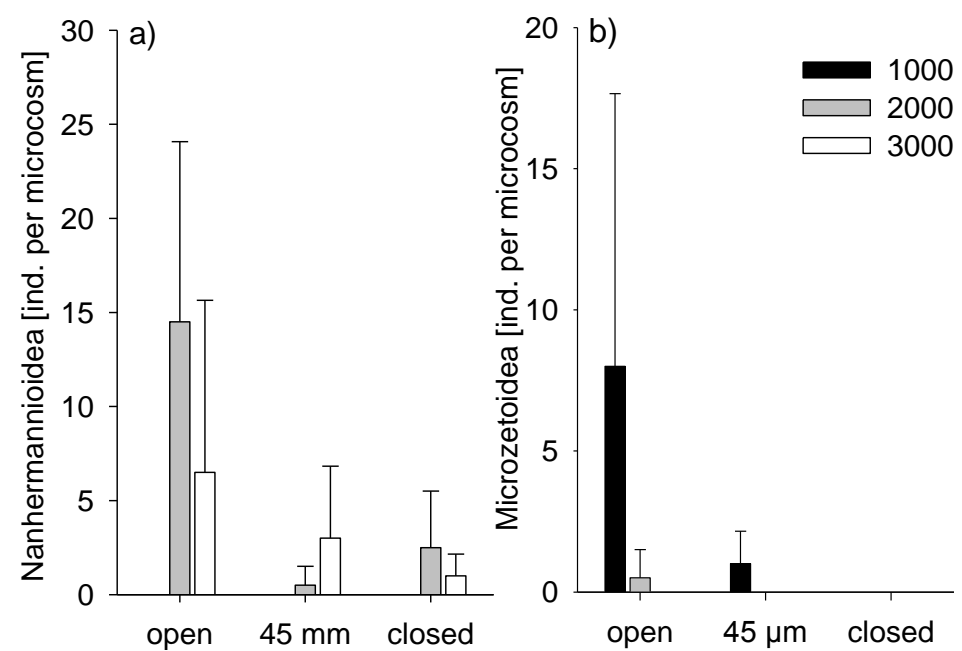

Fig. 7: Mean abundances and standard deviation of the two Oribatida subgroups (Nanhermannioidea (a)) and Microzetoidea (b)) reacting significantly towards the interaction of treatment (open; $45 \mu \mathrm{m}$; closed) and altitude (1000, 2000 and 3000 m a.s.l.) (means \pm SD).

A total of 74 species of Oribatida were found at the three study sites. Oribatida species number varied significantly between altitudes $\left(F_{2 / 27}=39.6, p<0.001\right)$ and also between the treatments $\left(F_{2 / 27}\right.$ $=11.0, p<0.001)$. The species number was lowest at $3000 \mathrm{~m}\left(2.9 \pm 1.4\right.$ species microcosm $\left.^{-1}\right)$ and significantly higher at 1000 and $2000 \mathrm{~m}\left(10.7 \pm 6.1\right.$ and $10.1 \pm 3.8$ species microcosm $\left.{ }^{-1}\right)$. Between the treatments abundance was highest in open $\left(11.3 \pm 6.9\right.$ species microcosm $\left.{ }^{-1}\right)$ and lower in $45 \mu \mathrm{m}$ and closed microcosms (6.9 \pm 3.7 and $5.5 \pm 3.7$ species microcosm ${ }^{-1}$, respectively).

PCA of the Oribatida community at each of the three altitudes separated the three treatments along the first axis (Fig. 8a,b,c). At 1000 m most species were associated with open microcosms, only Trachyoribates n.sp. (3), Tegeocranellus bolivianus, Cultroribula zicsii and two species of Suctobelbidae were associated with $45 \mu \mathrm{m}$ and closed microcosms. Species of Suctobelbidae, which generally were more abundant in open microcosms (Fig. 8a), spread over the full gradient from closed to open microcosms.

At $2000 \mathrm{~m}$ the separation between closed, $45 \mu \mathrm{m}$ and open microcosms was less pronounced as compared to $1000 \mathrm{~m}$ (Fig. 8b). Most species were again associated with open microcosms, although the association was not as pronounced as at $1000 \mathrm{~m}$. 
a)

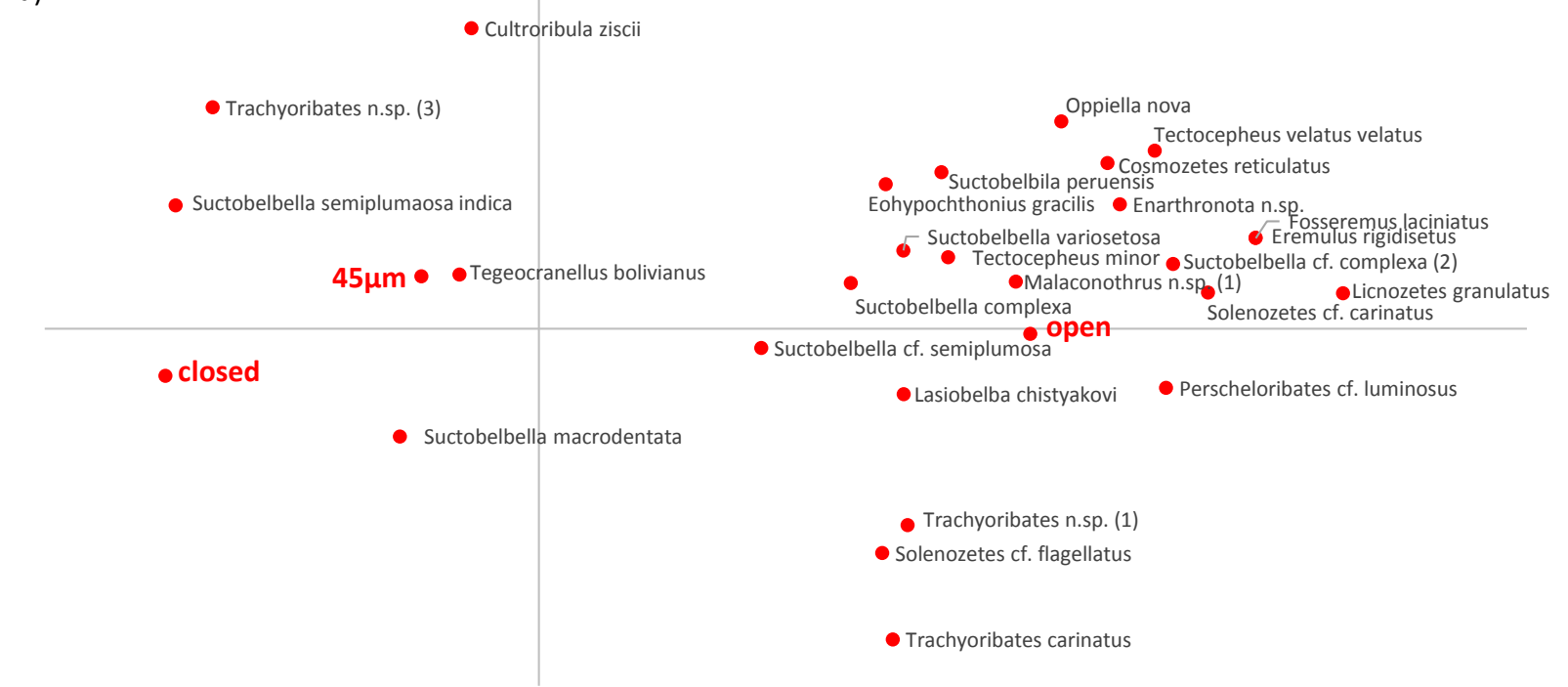

b)

c)

- Damaeus cf. flagellatus

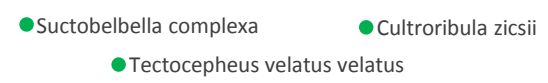

- closed

\section{- Suctobelbella macrodentata}

- Ceratorchestes globosus

- Oppiella nova

- Nanhermannia nana

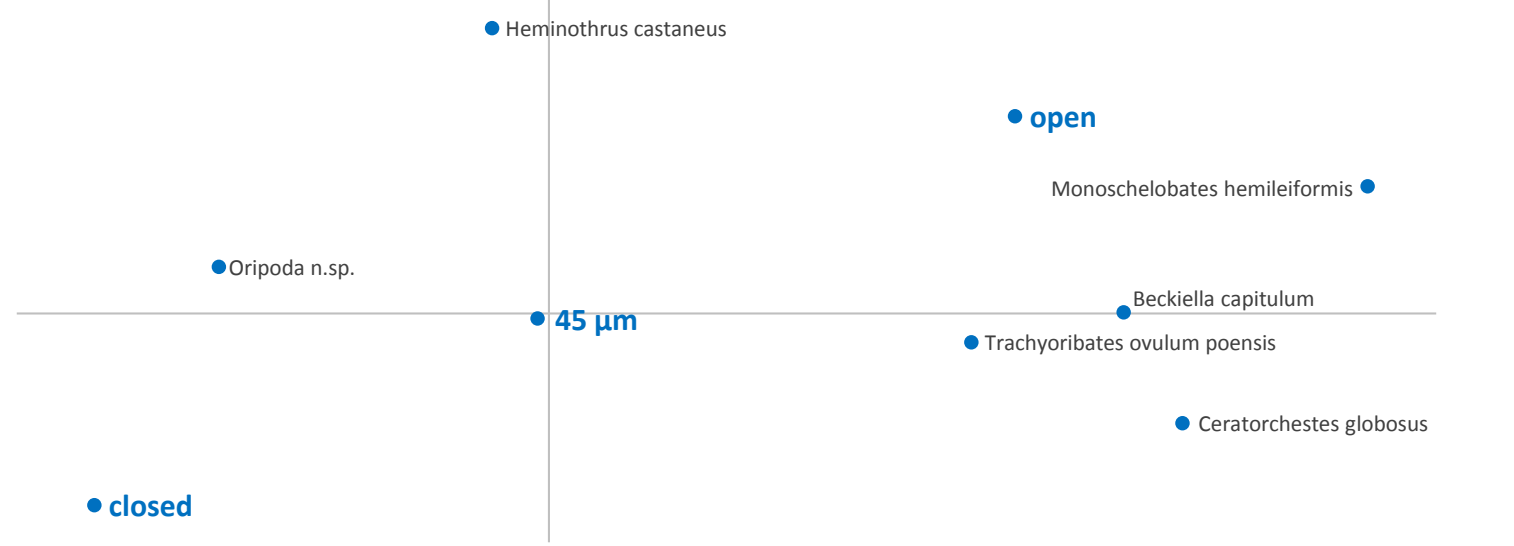

Fig. 8: PCA-log plot of Oribatida species in open, $45 \mu \mathrm{m}$ and closed microcosms at (a) $1000 \mathrm{~m}$ (Eigenvalue of axis 1 is 0.23 and axis 2 is 0.35 ), (b) $2000 \mathrm{~m}$ (Eigenvalues of axis 1 is 0.23 and axis 2 is 0.34 ) and (c) $3000 \mathrm{~m}$ (Eigenvalues of axis 1 is 0.4 and axis 2 is 0.35 ). (See Appendix for internal classification numbers of Oribatida species) 
The species associated with the closed and $45 \mu \mathrm{m}$ microcosms at $2000 \mathrm{~m}$ were not present at 1000 m, Damaeus cf. flagellatus, Beckiella capitulum, Globoppia cf. maior and Scheloribates elegans. Again, species of Suctobelbidae and Oppiidae were spread over the full gradient. At $3000 \mathrm{~m}$ species numbers were substantially lower, with four of the seven species present being associated with the open microcosms (Fig. 8c) and these four species not being present at the lower altitudes, Nanhermannia nana, Oripoda n.sp. and Heminothrus castaneus. Closed and $45 \mu \mathrm{m}$ microcosms were more distantly separated at $3000 \mathrm{~m}$ as compared to the lower altitudes.

\section{Discussion}

The lack of variation in the treatment effect between the three investigated altitudes, with the exception of Collembola abundance, contradicts the assumption that the role of mycorrhizal fungi for both decomposition and soil fauna community structure increases with decreasing quality of the litter resource and harshness of abiotic conditions. This suggests that at each of the altitudes the influence of root-derived resources for microorganisms and animals is of similar importance. We therefore discuss the effects of root and mycorrhizal exclusion and variations along the altitudinal gradient separately.

\section{Exclusion of roots and mycorrhiza}

The lack of treatment effects on litter decomposition and C-to-N ratio questions the widely assumed role of mycorrhizal fungi in decomposition processes. Gadgil and Gadgil (1971) found decomposition rates to decrease in the presence of EM fungi and attributed this effect to either increased competition between EM fungi and saprotrophs or changes in the soil water content. The water content being only significantly lower in the open as compared to the closed and $45 \mu \mathrm{m}$ microcosms suggests that the exclusion of roots and therefore the missing water uptake by plants was responsible for the lower water content in the litter layer of the open as compared to the closed and $45 \mu \mathrm{m}$ microcosms (Brant et al., 2006). The fact that only roots in the open but not mycorrhiza in the $45 \mu \mathrm{m}$ microcosms affected the water content in the litter layer indicates that mycorrhiza little affected the drainage of the microcosms. AM fungi have been shown to influence decomposition rates in both directions by accelerating decomposition rates of grass leaves (Hodge et al., 2001; Hodge \& Fitter, 2010), but also reducing the decomposition rate of woody plant litter (Leifheit et al., 2015). Mycorrhizal fungi at the study sites are dominated by AM fungi (Kottke et al., 2004) and results of the present study suggest that they do not alter litter decomposition at any of the three studied altitudes. AM fungi transfer not only P (Smith \& Read, 2008), but also N to their host plant (Hodge et al., 2001; Leigh et al., 2009; Veresoglou et al., 2012), while in exchange $C$ is transferred from the host plant to the mycorrhizal fungi. In a tropical coffee plantation Cuenca et al. 
(1983) reported a decrease in litter $\mathrm{N}$ in the presence of coffee roots, however, in most studies the transfer of N by mycorrhiza did not affect N concentrations in leaf litter (Gadgil \& Gadgil, 1975; Staaf, 1988; Zhu \& Ehrenfeld, 1996). In the present study the litter C-to-N ratio also neither was affected by the exclusion of roots nor by mycorrhizal hyphae, suggesting that litter $\mathrm{N}$ dynamics were independent of roots and mycorrhiza. Only few studies investigated interactions between AM fungi and soil microorganisms distant to roots (Hodge \& Fitter, 2010; Nuccio et al., 2013), although AM fungi are known to form pronounced extra-radical mycelia growing into decomposing litter material (Camenzind \& Rillig, 2013) suggesting that they interact with saprotrophic fungi (Marschner et al., 2001; Marschner \& Baumann, 2003; Camenzind \& Rillig, 2013). Indeed, AM fungi have been shown to modify the abundance as well as community composition of bacteria in litter (Marschner \& Baumann, 2003; Nuccio et al., 2013) and Leigh et al. (2011) found antagonistic interactions between AM fungi and bacteria suggesting that they compete for resources. Especially in P limited systems the extra-radical hyphae of AM fungi and the microbial community are assumed to compete for $P$ (Leigh et al., 2011; Nottingham et al., 2013). The investigated tropical montane rainforests are colimited by both $\mathrm{N}$ and $\mathrm{P}$ (Homeier et al., 2012) and addition of both nutrients has been shown to impact AM fungi abundance and diversity (Camenzind et al., 2014) as well as the microbial community (Krashevska et al., 2010). This suggests antagonistic interactions between mycorrhizal fungi and saprotrophic microorganisms to be pronounced at our study sites as suggested earlier (Krashevska et al., 2010). Conform to these expectations exclusion of mycorrhizal hyphae and roots resulted in an increase in basal respiration and in trend also in $\mathrm{C}_{\text {mic }}$, suggesting that mycorrhizal fungi in fact suppressed the activity of saprotrophic microorganisms. The fact that this was independent of the presence of roots suggests that these interactions occurred between the extraradical mycorrhizal mycelia and saprotrophic microorganisms in litter. As documented above, however, these interactions did not translate into changes in litter decomposition and litter $\mathrm{N}$ dynamics. Potentially, this is related to limitations of the experimental system used with rather large diameter of microcosms limiting interactions between mycorrhiza and saprotrophic microorganisms.

As expected, the exclusion of roots and mycorrhizal hyphae affected the abundance and community composition of soil microarthropods, however, overall the effects were rather small. The abundance of total microarthropods was significantly lower in closed microcosms with a trend towards lower abundance in the root-exclusion microcosms at each of the three altitudes, suggesting that microarthropods benefited from open microcosms and the ingrowth of roots. An increasing number of studies in temperate forests highlighted the importance of root-derived resources for fuelling soil food webs (Pollierer et al., 2007, 2012; Zieger et al., 2015), but whether this also applies to tropical montane rainforests is unclear. Hishi et al. (2008) showed for a 
temperate forest system that the density of Oribatida and Collembola correlates with fine root biomass and hyphal length with Oribatida relying more on root derived resources than Collembola. In the present study, density of Collembola at 1000 and 2000 m were at a maximum in closed microcosms suggesting that they benefited from exclusion of mycorrhizal hyphae, potentially due to flourishing of saprotrophic fungi in absence of mycorrhizal fungi. This is consistent with the increase in basal respiration and $\mathrm{C}_{\text {mic }}$ (in trend) in the closed microcosms. The results therefore suggest that Collembola at the lower altitude study sites mainly rely on saprotrophic microorganisms rather than mycorrhizal fungi as food supporting the findings of Hishi et al. (2008). Recently, Potapov et al. (2015) provided strong evidence that Collembola in temperate forests also do not incorporate mycorrhizal carbon, further supporting the suggestion that Collembola mainly rely on litter derived resources. Typically, the density of Collembola and Oribatida respond in parallel, e.g. both are more abundant in acidic as compared to base rich forest ecosystems and both suffer from the activity of macrofauna species, in particular earthworms (Eisenhauer, 2010). Similar to Collembola (Chahartaghi et al., 2005), Oribatida are trophically diverse and span over three to four trophic levels from primary decomposers to predators (Walter \& Proctor, 1998; Schneider et al., 2004; Maraun et al., 2007). Recent studies conducted in the temperate region suggest that Oribatida species heavily rely on root-derived resources (Schneider et al., 2005; Pollierer et al., 2007; Remen et al., 2010; Zieger et al., 2015) and sensitively respond to resource limitation (Domes et al., 2007). Low density and diversity of Oribatida in microcosms in which roots and mycorrhizal hyphae were excluded are consistent with these findings. Reduced diversity indicates that exclusion of roots and mycorrhiza not only reduced the amount of resources available but also the number of trophic niches in the system. The few species which were abundant in the closed and $45 \mu \mathrm{m}$ microcosms belonged to different Oribatida families and feeding guilds. Unfortunately, however, little is known on food resources of tropical Oribatida species but e.g. Cultroribula zicsii which was abundant in $45 \mu \mathrm{m}$ and closed microcosms at $1000 \mathrm{~m}$ was found to be associated with fresh litter material suggesting litter as main food resource (Illig et al., 2005). Similarly, Heminothrus castaneus and Nanhermannia nana which were abundant in closed and $45 \mu \mathrm{m}$ microcosms at $3000 \mathrm{~m}$ are assumed to mainly feed on litter material and associated saprotrophic microorganisms (Illig et al., 2005). However, Suctobelbidae of which two species were associated with closed and $45 \mu \mathrm{m}$ microcosms at $1000 \mathrm{~m}$ are assumed to mainly feed on liquids, but it is unknown whether liquids are of plant, fungal or animal origin. The fact that many Oribatida species were associated with open microcosms suggests that the lack of root-derived resources cannot easily be compensated by switching to other food resources (Domes et al., 2007).

Despite the fact that soil microorganisms and microarthropods responded in a consistent way to the exclusion of roots and/or mycorrhizal hyphae caution is needed interpreting the results of the 
present study in a causal way being due to the lack of root-derived resources. In addition to the lack of root-derived resources, reduced density of Oribatida in closed and $45 \mu \mathrm{m}$ microcosms may also have resulted from restricted colonisation of the litter material added to microcosms by Oribatida from outside the microcosms. However, Domes et al. (2007) showed that, although colonization of soil cores by Oribatida from soil is slower than colonization from litter, the individuals and eggs present in soil are sufficient to ensure establishment of a diverse community of Oribatida. Also, especially at higher altitudes, only part of the organic layers had been removed, enabling litter species to colonise the added leaf litter material. In fact, compared to the initial density in the soil layer added to the microcosms at the beginning of the experiment, the abundances in the microcosms at the end of the experiment had increased in virtually all soil fauna groups investigated. The consistent pattern of the response of soil microorganisms and microarthropods at each of the altitudes as well as the increased abundance of Collembola in closed microcosms indicates that the response indeed can be attributed to the exclusion of roots and mycorrhizal fungi and not only to colonization bias between open, closed and $45 \mu \mathrm{m}$ microcosms.

\section{Altitude}

In the studied region many ecosystem processes and characteristics have been shown to vary along the studied altitudinal gradient (Homeier et al., 2002; Röderstein et al., 2005; Leuschner et al., 2007; Moser et al., 2007; Krashevska et al., 2007; Illig et al., 2010). The strong influence of altitude on the investigated parameters in the present study therefore is consistent with earlier findings (F. Marian, unpublished data, Chapter 2 and 3; Krashevska et al., 2007; Illig et al., 2008), although unexpectedly the influence of root exclusion did not differ significantly between the altitudes. Soil humidity at the study site increases with increasing altitude due to increased precipitation (Leuschner et al., 2007; Moser et al., 2007). The lower soil water content at $1000 \mathrm{~m}$ as compared to 2000 and $3000 \mathrm{~m}$ indicates that in addition to lower precipitation the mineral soil at $1000 \mathrm{~m}$ has a lower water holding capacity than the organic layers underlying the litter at 2000 and $3000 \mathrm{~m}$.

The variation in decomposition rates between the three altitudes differs from the pattern previously reported for the study sites with litter decomposition decreasing with increasing altitude (F. Marian, unpublished data, Chapter 2). This decrease in decomposition rate with increasing altitude has been associated with changes in biotic and abiotic conditions, such as increased water logging (Wilcke et al., 2002) and changes in plant community structure (F. Marian, unpublished data, Chapter 2). Parallel to the decrease in decomposition, the litter quality (C-to- $\mathrm{N}$ ratio) also decreases with increasing altitude (F. Marian, unpublished data, Chapter 2; Wilcke et al., 2002; Leuschner et al., 2007), but variations in litter quality were found to be of little importance as drivers of litter decomposition at our study sites (F. Marian, unpublished data, Chapter 2). Also, the 
differences in decomposition rates between the altitudes were found to increase as decomposition continues, while within the first 12 months decomposition rates did not vary strongly between the three altitudes (F. Marian, unpublished data, Chapter 2). Compared to the decomposition rates reported in a previous study (F. Marian, unpublished data, Chapter 2 ) the litter lost about $7 \%$ more mass at $3000 \mathrm{~m}$ while at $1000 \mathrm{~m}$ litter lost about $10 \%$ less mass, whereas the decomposition rate at $2000 \mathrm{~m}$ was almost identical to previous studies.

The different patterns in which the microbial parameters varied in soil and litter along the altitudinal gradient indicate that different regulatory forces control the microbial community in the two layers. In the soil layer where biomass and respiration have been shown to be lower compared to the litter layer (Krashevska et al., 2008), both parameters were low at the $1000 \mathrm{~m}$ altitude reflecting the high concentration of mineral material in this layer (Ah horizon). In the litter layer the opposite pattern, i.e. increased microbial biomass at $1000 \mathrm{~m}$ compared to the higher altitudes, indicates that increased nutrient availability due to higher litter quality and temperature at $1000 \mathrm{~m}$ provides favourable conditions for microorganisms as suggested before (Krashevska et al., 2010). Variations in the diversity and abundance of microarthropod species along altitudinal gradients have been studied extensively (Richardson et al., 2005; González et al., 2007; Sanders et al., 2009; Sundqvist et al., 2013; Willig \& Presley, 2015). In the study area both the abundance and diversity of soil arthropods are known to vary along the altitudinal gradient (F. Marian, unpublished data, Chapter 3; Rillig et al., 2013). Contrary to the present study, where the abundance of most investigated microarthropod groups was at a maximum at the intermediate altitude and Oribatida diversity did not differ between 1000 and 2000 m, previous studies using litterbags or soil cores found a decrease in soil arthropod abundance with increasing altitude (F. Marian, unpublished data, Chapter 3; Maraun et al., 2008; Illig et al., 2010; Rillig et al., 2013). Also, the diversity of plants, moths, testate amoebae and Oribatida have previously been found to vary along the altitudinal gradient (Krashevska et al., 2007, 2008; Homeier et al., 2010; Rillig et al., 2013; Brehm et al., 2013). Testate amoebae diversity was highest at the $2000 \mathrm{~m}$ site (Krashevska et al., 2007) while Oribatida diversity decreased with increasing altitude (F. Marian, unpublished data, Chapter 3; Illig et al., 2010; Rillig et al., 2013). The decrease in both diversity and abundance of soil microarthropods with altitude has been attributed to variations in the microbial community and the decreasing quality and diversity of belowground plant-derived resources (mainly via mycorrhizal and root exudate input) (F. Marian, unpublished data, Chapter 3). The hump shape pattern of microarthropod abundance and the missing increase in Oribatida species numbers at $1000 \mathrm{~m}$ in the present study suggests that other factors than belowground resources influence microarthropod abundance and diversity. The hump shaped distribution pattern of Oribatida and Collembola, corresponds to variations in decomposition rates at the different altitudes. The matching pattern of decomposition 
rates, litter C-to-N ratio and Collembola abundance supports our conclusion that Collembola heavily rely on litter resources and litter associated saprotrophic microorganisms.

Previous studies reporting microarthropod abundance to decrease with increasing altitude have been conducted in the wet season in April and May (F. Marian, unpublished data, Chapter 3; Rillig et al., 2013). The hump shaped pattern in the abundance and diversity of testate amoebae along the studied altitudinal gradient was reported in a study conducted in the dry season of autumn 2006 (Krashevska et al., 2007, 2008). Testate amoebae as well as soil microarthropods (Acari and Collembola) are sensitive to drought (Lindberg et al., 2002; Krashevska et al., 2012). Studies on the effects of seasonality in tropical montane rainforests on soil invertebrates are scarce although variations in plant functional traits vary with seasonal changes in precipitation and humidity (Ortiz et al., 2006; Bendix et al., 2006). Virtually nothing is known on the influence of these seasonal changes on the soil fauna community. The results of the present study point towards seasonal variations, e.g. drought or drought related changes in the plant soil fauna interaction, as a possible cause for the low abundance of microarthropods and low Oribatida diversity at the lowest altitude. Surprisingly the abundance of the predatory Acarina groups Gamasina and Uropodina as well as some of the Oribatida families did not follow a hump shaped pattern indicating that factors driving the abundance of these groups differ from those driving the abundance of Oribatida. Additionally, in Collembola, which are little sclerotized and therefore more sensitive to low humidity than e.g., Oribatida, all morphogroups reached highest abundance at the $2000 \mathrm{~m}$ site.

\section{Conclusions}

Results of the present study indicate that in nutrient limited Andean tropical montane rainforests mycorrhizal fungi and saprotrophic microorganisms compete for litter-derived resources, with mycorrhizal fungi suppressing the activity of saprotrophic microorganisms at each of the investigated altitudes. Reduced densities of soil microarthropods with root and mycorrhizal exclusion highlight the importance of root-derived resources for fuelling soil food webs, with exclusion of roots and mycorrhiza not only reducing the amount of resources available for Oribatida but also the number of trophic niches in the system. Collembola, on the other hand, appear to benefit from reduced competition between mycorrhizal fungi and saprotrophic microorganisms, indicating that they heavily depend on litter-derived resources. Further research on interactions between mycorrhizal fungi and bacteria is needed to reconcile the debate on the importance of mycorrhizal fungi in decomposition processes and the importance of root-derived resources as food source for the soil fauna community in particular in tropical rainforests. Variations in decomposition rates as well as microarthropod abundance and diversity along the altitudinal gradient did not fit previously reported patterns pointing to the importance of seasonal variations, e.g. drought or 
drought related changes, for plant-soil fauna interactions influencing belowground ecosystem processes stronger than previously thought, especially at lower altitudes. Further studies investigating the importance of seasonal variations for belowground interactions in tropical montane rainforests are needed to understand the forces driving major ecosystem processes such as litter decomposition and nutrient cycling.

\section{Acknowledgements}

Financial support was provided by the German Research Foundation (DFG) within the scope of the Research Unit 816 "Tropical Mountain Forest (TMF): Biodiversity \& Sustainable Management of a Mega Diverse Mountain Ecosystem in South Ecuador".

Measurements of $\mathrm{C}$ and $\mathrm{N}$ contents were performed by Ute Schlonsog in the laboratory of Prof. Dr. Christoph Leuschner (Göttingen/Germany).

We thank the German and Ecuadorian students and helpers for their support in the establishment of the experimental field sites, with collection of samples and their work in the laboratory.

\section{References}

Anderson JPE, Domsch KH. 1978. A physiological method for the quantitative measurement of microbial biomass in soils. Soil Biology and Biochemistry 10: 215-221.

Averill C, Turner BL, Finzi AC. 2014. Mycorrhiza-mediated competition between plants and decomposers drives soil carbon storage. Nature 505: 543-545.

Bais HP, Weir TL, Perry LG, Gilroy S, Vivanco JM. 2006. The role of root exudates in rhizosphere interactions with plants and other organisms. Annual Review of Plant Biology 57: 233-266.

Balogh J, Balogh P. 1988. Oribatid Mites of the neotropical region 1\&2. Elsevier Sience Publishers.

Balogh J, Balogh P. 2002. Identification Keys to the Oribatid Mites of the Extra-Holarctic Regions 1\&2. Miskolc.

Bardgett RD. 2005. The Biology of Soil: A community and ecosystem approach. Oxford: Oxford University Press.

Bardgett RD, Bowman WD, Kaufmann R, Schmidt SK. 2005. A temporal approach to linking aboveground and belowground ecology. Trends in ecology \& evolution 20: 634-641.

Barthlott W, Mutke J, Rafiqpoor D, Kier G, Kreft H. 2005. Global centers of vascular plant diversity. Nova Acta Leopoldina 92: 61-83.

Beck T, Joergensen RG, Kandeler E, Makeschin F, Nuss E, Oberholzer HR, Scheu S. 1997. An interlaboratory comparison of ten different ways of measuring soil microbial biomass C. Soil Biology and Biochemistry 29: 1023-1032.

Bending GD. 2003. Litter decomposition, ectomycorrhizal roots and the 'Gadgil' effect. New Phytologist 158: 227-238. 
Bendix J, Homeier J, Cueva EO, Emck P, Breckle S-W, Richter M, Beck E. 2006. Seasonality of weather and tree phenology in a tropical evergreen mountain rain forest. International journal of biometeorology 50: 370-384.

Brant JB, Myrold DD, Sulzman EW. 2006. Root controls on soil microbial community structure in forest soils. Oecologia 148: 650-659.

Brehm G, Fiedler K, Häuser CL, Dalitz H. 2008. Methodical Challenges of a Megadiverse Ecosystem. In: Beck E, ed. Gradients in a Tropical Mountain Ecosystem of Ecuador. Ecological Studies. Heidelberg: Springer-Verlag Berlin, 41-47.

Brehm G, Strutzenberger P, Fiedler K. 2013. Phylogenetic diversity of geometrid moths decreases with elevation in the tropical Andes. Ecography 36: 1247-1253.

Butenschoen O, Krashevska V, Maraun M, Marian F, Sandmann D, Scheu S. 2014. Litter mixture effects on decomposition in tropical montane rainforests vary strongly with time and turn negative at later stages of decay. Soil Biology and Biochemistry 77: 121-128.

Camenzind T, Hempel S, Homeier J, Horn S, Velescu A, Wilcke W, Rillig MC. 2014. Nitrogen and phosphorus additions impact arbuscular mycorrhizal abundance and molecular diversity in a tropical montane forest. Global Change Biology 20: 3646-3659.

Camenzind T, Rillig MC. 2013. Extraradical arbuscular mycorrhizal fungal hyphae in an organic tropical montane forest soil. Soil Biology and Biochemistry 64: 96-102.

Cesarz S, Fender A-C, Beyer F, Valtanen K, Pfeiffer B, Gansert D, Hertel D, Polle A, Daniel R, Leuschner $\mathrm{C}$, et al. 2013. Roots from beech (Fagus sylvatica L.) and ash (Fraxinus excelsior L.) differentially affect soil microorganisms and carbon dynamics. Soil Biology and Biochemistry 61: 23-32.

Chahartaghi M, Langel R, Scheu S, Ruess L. 2005. Feeding guilds in Collembola based on nitrogen stable isotope ratios. Soil Biology and Biochemistry 37: 1718-1725.

Cuenca G, Aranguren J, Herrera R. 1983. Root growth and litter decomposition in a coffee plantation under shade trees. Plant and Soil 71: 477-486.

Dennis PG, Miller AJ, Hirsch PR. 2010. Are root exudates more important than other sources of rhizodeposits in structuring rhizosphere bacterial communities? FEMS Microbiology Ecology 72: 313-327.

Domes K, Scheu S, Maraun M. 2007. Resources and sex: Soil re-colonization by sexual and parthenogenetic oribatid mites. Pedobiologia 51: 1-11.

Eisenhauer N. 2010. The action of an animal ecosystem engineer: Identification of the main mechanisms of earthworm impacts on soil microarthropods. Pedobiologia 53: 343-352.

Eissfeller V, Beyer F, Valtanen K, Hertel D, Maraun M, Polle A, Scheu S. 2013. Incorporation of plant carbon and microbial nitrogen into the rhizosphere food web of beech and ash. Soil Biology and Biochemistry 62: 76-81.

Ermilov SG, Sandmann D, Marian F, Maraun M. 2013a. Three new species of the genus Sternoppia (Acari: Oribatida: Sternoppiidae) from Ecuador. Zootaxa 3641: 565-576.

Ermilov SG, Sandmann D, Marian F, Maraun M. 2013b. New oribatid mites of the genera Machadobelba and Campachipteria Acari: Oribatida) from Ecuador. Systematic \& Applied Acarology 18: 145-152.

Ermilov SG, Sandmann D, Marian F, Maraun M. 2013c. New taxa and new records of oribatid mites 
of the family Galumnidae (Acari: Oribatida) from Ecuador. Zootaxa 3700: 259-270.

Farrar J, Hawes M, Jones D, Lindow S. 2003. How roots control the flux of carbon to the rhizosphere. Ecology 84: 827-837.

Franklin E, Hayek T, Fagundes EP, Silva LL. 2004. Oribatid mite (Acari: Oribatida) contribution to decomposition dynamic of leaf litter in primary forest, second growth, and polyculture in the Central Amazon. Brazilian journal of biology 64: 59-72.

Friese CF, Allen MF. 1991. The spread of VA mycoorrhizal fungal hyphae in the soil: Inoculum types and external hyphal architecture. Mycologia 83: 409-418.

Gadgil RL, Gadgil PD. 1971. Mycorrhiza and litter decomposition. Nature 233: 133.

Gadgil RL, Gadgil PD. 1975. Suppression of litter decomposition by mycorrhizal roots of Pinus radiata. New Zealand Journal of Forestry Science 5: 33-41.

Gange A. 2000. Arbuscular mycorrhizal fungi, Collembola and plant growth. Trends in ecology \& evolution 15: 369-372.

González G, García E, Cruz V, Borges S, Zalamea M, Rivera MM. 2007. Earthworm communities along an elevation gradient in Northeastern Puerto Rico. European Journal of Soil Biology 43: S24-S32.

Graefe S, Hertel D, Leuschner C. 2008. Fine root dynamics along a 2,000 m elevation transect in South Ecuadorian mountain rainforests. Plant and Soil 313: 155-166.

Haug I, Lempe J, Homeier J, Weiß M, Setaro S, Oberwinkler F, Kottke I. 2004. Graffenrieda emarginata (Melastomataceae) forms mycorrhizas with Glomeromycota and with a member of the Hymenoscyphus ericae aggregate in the organic soil of a neotropical mountain rain forest. Canadian Journal of Botany 82: 340-356.

Henderson A, Churchill SP, Luteyn JL. 1991. Neotropical plant diversity. Nature 351: 21-22.

Heneghan L, Coleman DC, Zou X, Crossley DA, Haines BL. 1999. Soil microarthropod contributions to decomposition dynamics: Tropical-temperate comparisons of a single substrate. Ecology 80: 1873-1882.

Hishi T, Fujimaki R, McGonigle TP, Takeda H. 2008. Relationships among fine roots, fungal hyphae and soil microarthropods among different soil microhabitats in a temperate coniferous forest of Chamaecyparis obtusa. European Journal of Soil Biology 44: 473-477.

Hobbie SE. 1992. Effects of plant species on nutrient cycling. Trends in ecology \& evolution 7: 336339.

Hodge A, Campbell CD, Fitter AH. 2001. An arbuscular mycorrhizal fungus accelerates decomposition and acquires nitrogen directly from organic material. Nature 413: 297-299.

Hodge A, Fitter AH. 2010. Substantial nitrogen acquisition by arbuscular mycorrhizal fungi from organic material has implications for $\mathrm{N}$ cycling. Proceedings of the National Academy of Sciences of the United States of America 107: 13754-13759.

Homeier J, Breckle S-W, Günter S, Rollenbeck RT, Leuschner C. 2010. Tree diversity, forest structure and productivity along altitudinal and topographical gradients in a species-rich Ecuadorian montane rain forest. Biotropica 42: 140-148.

Homeier J, Dalitz H, Breckle S-W. 2002. Waldstruktur und Baumdiversität im montanen Regenwald der Estación Cientifíca San Francisco in Südecuador. Bericht der Reinhessischen TüxenGesellschaft 14: 109-118. 
Homeier J, Hertel D, Camenzind T, Cumbicus NL, Maraun M, Martinson GO, Poma LN, Rillig MC, Sandmann D, Scheu S, et al. 2012. Tropical Andean forests are highly susceptible to nutrient inputs-Rapid effects of experimental $\mathrm{N}$ and $\mathrm{P}$ addition to an Ecuadorian montane forest. PloS one 7: e47128.

Illig J, Langel R, Norton RA, Scheu S, Maraun M. 2005. Where are the decomposers? Uncovering the soil food web of a tropical montane rain forest in southern Ecuador using stable isotopes (15N). Journal of Tropical Ecology 21: 589-593.

Illig J, Norton RA, Scheu S, Maraun M. 2010. Density and community structure of soil- and barkdwelling microarthropods along an altitudinal gradient in a tropical montane rainforest. Experimental and Applied Acarology 52: 49-62.

Illig J, Schatz H, Scheu S, Maraun M. 2008. Decomposition and colonization by micro-arthropods of two litter types in a tropical montane rain forest in southern Ecuador. Journal of Tropical Ecology 24: 157-167.

Joergensen RG, Scheu S. 1999. Depth gradients of microbial and chemical properties in moder soils under beech and spruce. Pedobiologia 43: 134-144.

Johnson D, Krsek M, Wellington EMH, Stott AW, Cole L, Bardgett RD, Read DJ, Leake JR. 2005. Soil invertebrates disrupt carbon flow through fungal networks. Science (New York, N.Y.) 309: 1047.

Johnson NC, Rowland DL, Corkidi L, Egerton-Warburton LM, Allen EB. 2003. Nitrogen enrichment alters mycorrhizal allocation at five mesic to semiarid grasslands. Ecology 84: 1895-1908.

Kempson D, Lloyd M, Ghelardi R. 1963. A new extractor for woodland litter. Pedobiologia 3: 1-21.

Kitayama K, Aiba S-I. 2002. Ecosystem structure and productivity of tropical rain forests along altitudinal gradients with contrasting soil phosphorus pools on Mount Kinabalu, Borneo. Journal of Ecology 90: 37-51.

Koller R, Rodriguez A, Robin C, Scheu S, Bonkowski M. 2013. Protozoa enhance foraging efficiency of arbuscular mycorrhizal fungi for mineral nitrogen from organic matter in soil to the benefit of host plants. New Phytologist 199: 203-211.

Kottke I, Beck A, Oberwinkler F, Homeier J, Neill D. 2004. Arbuscular endomycorrhizas are dominant in the organic soil of a neotropical montane cloud forest. Journal of Tropical Ecology 20: 125-129.

Krashevska V, Bonkowski M, Maraun M, Ruess L, Kandeler E, Scheu S. 2008. Microorganisms as driving factors for the community structure of testate amoebae along an altitudinal transect in tropical mountain rain forests. Soil Biology and Biochemistry 40: 2427-2433.

Krashevska V, Bonkowski M, Maraun M, Scheu S. 2007. Testate amoebae (protista) of an elevational gradient in the tropical mountain rain forest of Ecuador. Pedobiologia 51: 319331.

Krashevska V, Maraun M, Ruess L, Scheu S. 2010. Carbon and nutrient limitation of soil microorganisms and microbial grazers in a tropical montane rain forest. Oikos 119: 10201028.

Krashevska V, Sandmann D, Maraun M, Scheu S. 2012. Consequences of exclusion of precipitation on microorganisms and microbial consumers in montane tropical rainforests. Oecologia 170: 1067-1076. 
Leifheit EF, Verbruggen E, Rillig MC. 2015. Arbuscular mycorrhizal fungi reduce decomposition of woody plant litter while increasing soil aggregation. Soil Biology and Biochemistry 81: 323328.

Leigh J, Fitter AH, Hodge A. 2011. Growth and symbiotic effectiveness of an arbuscular mycorrhizal fungus in organic matter in competition with soil bacteria. FEMS microbiology ecology 76 : 428-438.

Leigh J, Hodge A, Fitter AH. 2009. Arbuscular mycorrhizal fungi can transfer substantial amounts of nitrogen to their host plant from organic material. The New phytologist 181: 199-207.

Lepš J, Šmilauer P. 2003. Multivariate analysis of ecological data using CANOCO. Cambridge: Cambridge University Press.

Leuschner C, Moser G, Bertsch C, Röderstein M, Hertel D. 2007. Large altitudinal increase in tree root/shoot ratio in tropical mountain forests of Ecuador. Basic and Applied Ecology 8: 219230.

Lindberg N, Engtsson JB, Persson T. 2002. Effects of experimental irrigation and drought on the composition and diversity of soil fauna in a coniferous stand. Journal of Applied Ecology 39: 924-936.

Maraun M, Salamon JA, Schneider K, Schaefer M, Scheu S. 2003. Oribatid mite and collembolan diversity, density and community structure in a moder beech forest (Fagus sylvatica): Effects of mechanical perturbations. Soil Biology and Biochemistry 35: 1387-1394.

Maraun M, Sandmann D, Krashevska V, Norton RA, Scheu S. 2008. Soil Fauna. In: Beck E,, In: Bendix J, In: Kottke I,, In: Makeschin F,, In: Mosandl R, eds. Gradients in a Tropical Mountain Ecosystem of Ecuador (Ecological Studies 198). Springer-Verlag Berlin, 181-192.

Maraun M, Schatz H, Scheu S. 2007. Awesome or ordinary? Global diversity patterns of oribatid mites. Ecography 30: 209-216.

Marschner P, Baumann K. 2003. Changes in bacterial community structure induced by mycorrhizal colonisation in split-root maize. Plant and Soil 251: 279-289.

Marschner P, Crowley DE, Lieberei R. 2001. Arbuscular mycorrhizal infection changes the bacterial $16 \mathrm{~S}$ rDNA community composition in the rhizosphere of maize. Mycorrhiza 11: 297-302.

McNaughton SJ, Oesterheld M, Frank DA, Williams KJ. 1989. Ecosystem-level patterns of primary productivity and herbivory in teresstrial habitats. Nature 341: 142-144.

Moser G, Hertel D, Leuschner C. 2007. Altitudinal change in LAI and stand leaf biomass in tropical montane forests: a transect study in Ecuador and a pan-tropical meta-analysis. Ecosystems 10: 924-935.

Myers N, Mittermeier RA, Mittermeier CG, da Fonseca GAB, Kent J. 2000. Biodiversity hotspots for conservation priorities. Nature 403: 853-858.

Nottingham AT, Turner BL, Winter K, Chamberlain PM, Stott A, Tanner EVJ. 2013. Root and arbuscular mycorrhizal mycelial interactions with soil microorganisms in lowland tropical forest. FEMS microbiology ecology 85: 37-50.

Nuccio EE, Hodge A, Pett-Ridge J, Herman DJ, Weber PK, Firestone MK. 2013. An arbuscular mycorrhizal fungus significantly modifies the soil bacterial community and nitrogen cycling during litter decomposition. Environmental Microbiology 15: 1870-1881.

Olsson PA, Chalot M, Baath E, Finlay RD, Söderstöm B. 1996. Ectomycorrhizal mycelia reduce 
bacterial activity in a sandy soil. FEMS microbiology ecology 21: 77-86.

Ortiz EC, Homeier J, Breckle S-W, Bendix J, Emck P, Richter M, Beck E. 2006. Seasonality in an evergreen tropical mountain rainforest in southern Ecuador. Ecotropica 12: 69-85.

Paulsch A, Piechowski D, Müller-Hohenstein K. 2006. Forest vegetation structure along an altitudinal gradient in southern Ecuador. In: Beck $E_{,}$, In: Bendix J,, In: Kottke I,, In: Makeschin $F$, In: Mosandl R, eds. Gradients in a tropical mountain ecosystem of Ecuador. SpringerVerlag Berlin, 113-121.

Pollierer MM, Dyckmans J, Scheu S, Haubert D. 2012. Carbon flux through fungi and bacteria into the forest soil animal food web as indicated by compound-specific $13 \mathrm{C}$ fatty acid analysis (K Treseder, Ed.). Functional Ecology 26: 978-990.

Pollierer MM, Langel R, Körner C, Maraun M, Scheu S. 2007. The underestimated importance of belowground carbon input for forest soil animal food webs. Ecology letters 10: 729-736.

Potapov AM, Tiunov A V. 2015. Stable isotope composition of mycophagous collembolans versus mycotrophic plants: Do soil invertebrates feed on mycorrhizal fungi? Soil Biology and Biochemistry 93: 115-118.

Remen C, Fransson P, Persson T. 2010. Population responses of oribatids and enchytraeids to ectomycorrhizal and saprotrophic fungi in plant-soil microcosms. Soil Biology and Biochemistry 42: 978-985.

Richardson BA, Richardson MJ, Soto-Adames FN. 2005. Separating the effects of forest type and elevation on the diversity of litter invertebrate communities in a humid tropical forest in Puerto Rico. Journal of Animal Ecology 74: 926-936.

Rillig MC, Camenzind T, Gawlik J, Haug I, Maraun M, Sandmann D, Scheu S. 2013. Diversity in soil fungi, protists and microarthropods. In: Bendix J,, In: Beck $E_{,}$, In: Bräuning $A_{,}$, In: Makeschin

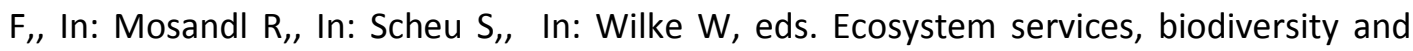
environmental change in a tropical mountain ecosystem of southern Ecuador. Springer Verlag, Berlin, Heidelberg, 81-92.

Röderstein M, Hertel D, Leuschner C. 2005. Above- and below-ground litter production in three tropical montane forests in southern Ecuador. Journal of Tropical Ecology 21: 483-492.

Sanders NJ, Dunn RR, Fitzpatrick MCF, Carlton CE, Pogue MR, Parker CR, Simons TR. 2009. Diverse elevational diversity gradients in Great Smoky Mountains National Park, USA. In: Spehn EM,, In: Körner C, eds. Data Mining for Global Trends inMountain Biodiversity. Boca Raton, $\mathrm{FL}:$ CRC Press, $75-88$.

Schaefer M, Ansorge H, Fiedler K, Sattler K, Scheu S, Schmidt E. 2010. Brohmer - Fauna von Deutschland (M Schaefer, Ed.). Wiebelsheim: Quelle \& Meyer Verlag.

Scheiner SM, Gurevitch J. 2001. Design and analysis of ecological experiments. Oxford University Press, USA.

Scheu S. 1992. Automated measurement of the respiratory response of soil microcompartments: active microbial biomass in earthworm faeces. Soil Biology and Biochemistry 24: 11131118.

Scheu S, Setälä H. 2002. Multitrophic interactions in decomposer food-webs. In: Tscharntke T,, In: Hawkins BA, eds. Multitrophic level interactions. Cambridge University Press, 223-264.

Schneider K, Renker C, Maraun M. 2005. Oribatid mite (Acari, Oribatida) feeding on ectomycorrhizal fungi. Mycorrhiza 16: 67-72. 
Schneider K, Renker C, Scheu S, Maraun M. 2004. Feeding biology of oribatid mites: a minireview. Phytophaga 14: 247-256.

Smith SE, Read D. 2008. Mycorrhizal Symbiosis. Amsterdam, Boston: Academic Press.

Staaf H. 1988. Litter decomposition in beech forests - effects of excluding tree roots. Biol Fertil Soils 6: 302-305.

Subias LS. 2015. Listado sistemático, sinonímico y biogeográfico de los ácaros oribátidos (Acariformes: Oribatida) del mundo (excepto fósiles),. http://www.ucm.es/info/zoo/Artropodos/Catalogo.pdf/: 564.

Sundqvist MK, Sanders NJ, Wardle D a. 2013. Community and ecosystem responses to elevational gradients: Processes, mechanisms, and insights for global change. Annual Review of Ecology, Evolution, and Systematics 44: 261-280.

Tanner EVJ. 1981. The decomposition of leaf litter in Jamaican montane rain forests. Journal of Ecology 69: 263-275.

Veresoglou SD, Chen B, Rillig MC. 2012. Arbuscular mycorrhiza and soil nitrogen cycling. Soil Biology and Biochemistry 46: 53-62.

Vohník M, Burdíková Z, Vyhnal A, Koukol O. 2011. Interactions between testate amoebae and saprotrophic microfungi in a scots pine litter microcosm. Microbial Ecology 61: 660-668.

Walter DE, Proctor HC. 1998. Feeding behaviour and phylogeny: observations on early derivative Acari. Experimental \& applied acarology 22: 39-50.

Wardle DA, Bardgett RD, Klironomos JN, Setälä H, van der Putten WH, Wall DH. 2004. Ecological linkages between aboveground and belowground biota. Science (New York, N.Y.) 304: 1629-1633.

Weigmann G. 2006. Die Tierwelt Deutschlands - Hornmilben (Oribatida). Keltern: Verlag Goecke \& Evers.

Wilcke W, Oelmann Y, Schmitt A, Valarezo C, Zech W, Homeier J. 2008. Soil properties and tree growth along an altitudinal transect in Ecuadorian tropical montane forest. Journal of Plant Nutrition and Soil Science 171: 220-230.

Wilcke W, Yasin S, Abramowski U, Valarezo C, Zech W. 2002. Nutrient storage and turnover in organic layers under tropical montane rain forest in Ecuador. European Journal of Soil Science 53: 15-27.

Willig MR, Presley SJ. 2015. Biodiversity and metacommunity structure of animals along altitudinal gradients in tropical montane forests. Journal of Tropical Ecology: 1-16.

Zhu W, Ehrenfeld JG. 1996. The effects of mycorrhizal roots on litter decomposition, soil biota, and nutrients in a spodosolic soil. Plant and Soil 179: 109-118.

Zieger SL, Eissfeller V, Maraun M, Scheu S. 2015. Incorporation of carbon and nitrogen from leaf litter differing in structural compounds into soil microarthropods of a deciduous forest. Pedobiologia 58: 219-227. 


\section{Appendix}

Species list: List of Oribatida species names (SN) and lead author, species number according to internal classification system ( $\mathrm{Nr}$.$) , total abundance and abundance at the three investigated altitudes (1000,2000$ and $3000 \mathrm{~m}$ ).

\begin{tabular}{|c|c|c|c|c|c|c|c|}
\hline \multicolumn{8}{|c|}{ Supercohorte (SC) } \\
\hline \multicolumn{8}{|c|}{ Cohorte (Co) } \\
\hline & \multicolumn{7}{|l|}{ Superfamiliy (SF) } \\
\hline & \multicolumn{2}{|l|}{ Family (Fa) } & \multicolumn{5}{|c|}{ abundance } \\
\hline & Subfamily (Su) & Species name (SN) & Nr. & 1000 & 2000 & 3000 & total \\
\hline \multicolumn{8}{|c|}{ Enarthronota } \\
\hline & \multicolumn{7}{|l|}{ Enarthronota sp. } \\
\hline & \multicolumn{7}{|l|}{ Nattifftofftidae } \\
\hline & & Enarthronota n.sp. & 317 & 20 & & & 20 \\
\hline & \multicolumn{7}{|l|}{ Hypochthonioidea } \\
\hline & \multicolumn{7}{|l|}{ Hypochthoniidae } \\
\hline & & Eohypochthonius gracilis (Jacot, 1936) & 139 & 14 & & & 14 \\
\hline \multicolumn{8}{|c|}{ Mixonomata } \\
\hline & hosomata & & & & & & \\
\hline & Lohmannioidea & & & & & & \\
\hline & Lohmanniidae & & & & & & \\
\hline & & Xenolohmannia comosa (P. Balogh, 1984) & 235 & & 1 & & 1 \\
\hline Desm & Iomatides & & & & & & \\
\hline & osomata & & & & & & \\
\hline & Crotonioidea & & & & & & \\
\hline & Trhypochthoniidae & & & & & & \\
\hline & & Afronothrus incisivus (Wallwork, 1961) & 341 & 1 & & & 1 \\
\hline & Malaconothridae & & & & & & \\
\hline & & Fossonothrusn.sp. & 57 & & 1 & & 1 \\
\hline & & Malaconothrus monodactylus (Michael, 1888) & 103 & & 3 & & 3 \\
\hline & & Malaconothrusn.sp. (1) & 300 & 2 & & & 2 \\
\hline & & Malaconothrusn.sp. (2) & 185 & 1 & & & 1 \\
\hline & Crotoniidae & & & & & & \\
\hline & 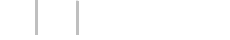 & Heminothrus castaneus (Hammer, 1961) & 132 & & & 4 & 4 \\
\hline & hypylina & & & & & & \\
\hline & Nanhermannioidea & & & & & & \\
\hline & Nanhermanniidae & & & & & & \\
\hline & & Nanhermannia nana (Nicolet, 1855) & 3 & & 35 & 21 & 56 \\
\hline & Hermannielloidea & & & & & & \\
\hline & Hermanniellidae & & & & & & \\
\hline & & Ampullobates ecuadoriensis (Ermilov, Starý, Sandmann, Marian, Maraun, 2013) & 272 & & 2 & & 2 \\
\hline & Plasmobatidae & & & & & & \\
\hline & & Solenozetes cf. carinatus & 264 & 8 & 1 & & 9 \\
\hline & & Solenozetes cf. flagellatus & 252 & 8 & & & 8 \\
\hline & Damaeoidea & & & & & & \\
\hline & Damaeidae & & & & & & \\
\hline & & Damaeus cf. flagellatus & 140 & & 19 & & 19 \\
\hline & Microzetoidea & & & & & & \\
\hline & Microzetidae & & & & & & \\
\hline & & Berlesezetes brazilozetoides (Balogh, Mahunka, 1981) & 288 & 1 & & & 1 \\
\hline & & Cosmozetes reticulatus (Balogh, 1962) & 93 & 5 & 1 & & 6 \\
\hline & & Eremulus rigidisetus (Balogh, Mahunka, 1969) & 253 & 2 & 1 & & 3 \\
\hline & & Licnozetes granulatus (Balogh, Mahunka, 1969) & 153 & 12 & & & 12 \\
\hline & Ameroidea & & & & & & \\
\hline & Damaeolidae & & & & & & \\
\hline & & Fosseremus laciniatus (Berlese, 1905) & 94 & 4 & & & 4 \\
\hline & Caleremaeidae & & & & & & \\
\hline & & Epieremulus granulatus (Balogh, Mahunka, 1979) & 240 & & 16 & & 16 \\
\hline & Rhynchoribatidae & & & & & & \\
\hline & & Rhynchoribates cf. mirus & 246 & & 2 & & 2 \\
\hline & Eremaeoidea & & & & & & \\
\hline & Arceremaeidae & & & & & & \\
\hline & & Tecteremaeus cornutus (Hammer, 1961) & 295 & 1 & & & 1 \\
\hline & Gustavioidea & & & & & & \\
\hline & Astegestidae & & & & & & \\
\hline & & Ceratorchestes globosus (Balogh, Mahunka, 1969) & 125 & & 9 & 2 & 11 \\
\hline & & Ceratorchestes n.sp. & 280 & 1 & & & 1 \\
\hline & & Cultroribula zicsii (Balogh, Mahunka, 1981) & 273 & 10 & 115 & & 125 \\
\hline & Carabodoidea & & & & & & \\
\hline & Dampfiellidae & & & & & & \\
\hline & & Beckiella capitulum (Balogh, Mahunka, 1978) & 241 & & 3 & 4 & 7 \\
\hline & Otocepheidae & & & & & & \\
\hline & & Plenotocepheus neotropicus (Ermilov, Sandmann, Marian, Maraun, 2013) & 1 & & 1 & & 1 \\
\hline
\end{tabular}




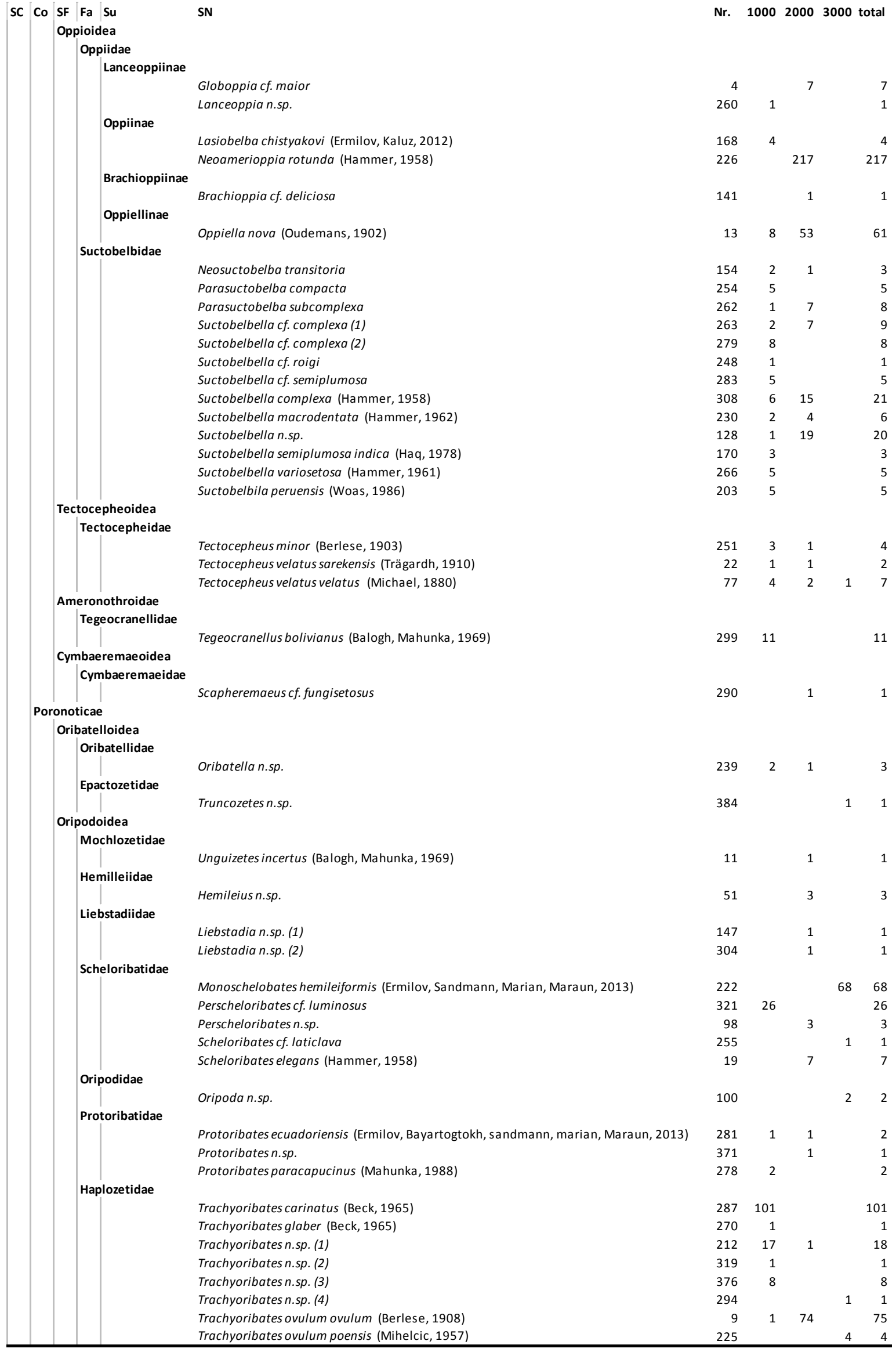




\section{Chapter 5}

\section{General Discussion}
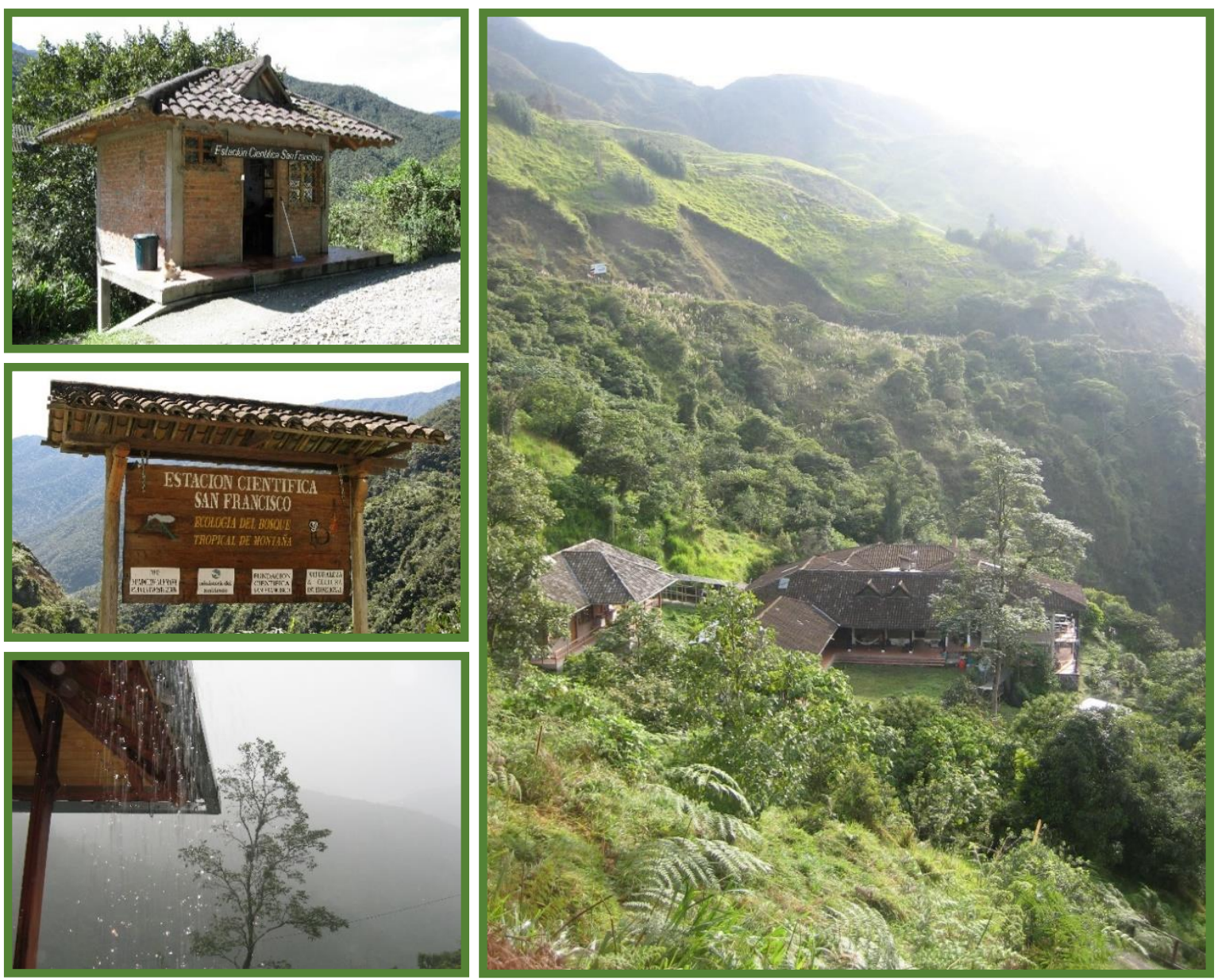


\section{Regulatory forces of litter decomposition}

The results of this thesis, particularly Chapter 2, demonstrate that in the investigated tropical montane ecosystems litter quality is far less important for decomposition processes than previously assumed and reported for other climatic regions (Coûteaux et al., 1995; Berg, 2014; Cleveland et al., 2014). In the studies presented in Chapter 2 and 4 mass loss of litter was mainly affected by altitude specific biotic and abiotic conditions and particularly the study presented in Chapter 2 showed that this relationship was independent of the quality of the local litter material. However, the pattern in which decomposition rates varied between the three investigated altitudes differed in the two studies. While in Chapter 2 the pattern was identical to those previously reported, with decomposition rates decreasing with increasing altitude (Illig et al., 2008), in Chapter 4 decomposition rates were found to be highest at the $2000 \mathrm{~m}$ site. Importantly, however, the sampling in the two studies took place in different seasons; i.e. in the study presented in Chapter 2 during the wet season in spring and in the study presented in Chapter 4 during the dry season in autumn. This suggests that decomposition processes in the investigated tropical montane ecosystem vary with seasonal changes in biotic and abiotic factors. Presumably, drought or drought related changes in plant - soil fauna interaction influence the decomposition rate at the investigated study sites.

The study presented in Chapter 2 also demonstrated that the differences in decomposition rates between the investigated altitudes became more pronounced as decomposition continued. Decomposition processes are known to undergo different stages with the early stage being characterized by fast mass loss through leaching of soluble compounds and decomposition of holocellulose (Berg \& McClaugherty, 2008; Berg, 2014). Especially this early phase of decomposition previously has been shown to strongly depend on the quality of litter material (Berg \& McClaugherty, 2008; Cusack et al., 2009) and conform to this pattern litter decomposition during this phase was found in this thesis to be largely independent of altitudinal variations. The investigation of long term decomposition processes along the altitudinal gradient in Chapter 2 revealed however, that after this initial phase of fast decomposition rates at all three altitudes, in later phases (after 12 months) decomposition rates varied between altitudes. Berg (2014) already found in temperate ecosystems that the rate of mass and $C$ loss of litter slows down in the second phase of decomposition and is dominated by the degradation of recalcitrant litter compounds such as lignin. Decomposition rates in this phase can even cease, reaching a limit value and leaving behind recalcitrant litter compounds which are little decomposed (Berg \& McClaugherty, 2008; Berg, 2014). In the results presented in Chapter 2 this, however, was only the case for litter material exposed at the 2000 and $3000 \mathrm{~m}$ sites clearly documenting a strong retardation in decomposition rate after 12 months which lasted for at least 24 months supporting earlier findings of Butenschoen 
et al. (2014). The results presented in Chapter 2, however, also demonstrate that this second phase is followed by a third phase characterised by a slow resumption of decomposition after 36 months. This phase likely is associated with the start of lignin degradation and a shift in the decomposer community towards lignin decomposing microorganisms. In contrast, at $1000 \mathrm{~m}$ decomposition continued after 12 months at a low but steady rate, resulting in over $80 \%$ mass loss after four years and indicating that in contrast to higher altitudes higher nutrient availability at $1000 \mathrm{~m}$ allowed continuous decomposition of litter including recalcitrant compounds such as lignin. We suggest that the different forest floor types at the different altitudes, with the litter layer being in close contact with mineral soil at $1000 \mathrm{~m}$, whereas thick layers of F-material separating leaf litter and mineral soil at higher altitudes, resulted in a feedback loop in which accumulation of organic material and the formation of thick $F$ layers at higher altitudes inhibits further decomposition. This effect is presumably further increased by the fact that the thick F layers at 2000 and $3000 \mathrm{~m}$ are formed in large by little decomposed root litter (Leuschner et al., 2007). Comparing the decomposition rates of leaf and root litter the results presented in Chapter 2 revealed that generally the retardation of mass loss after 12 months was more pronounced in root litter as compared to leaf litter where decomposition continued at a low rate. Presumably, this is due to root litter containing higher concentrations of lignin and lower concentrations of $N$ than leaf litter (Bloomfield et al., 1993; Berg \& McClaugherty, 2008), resulting in a stronger accumulation of recalcitrant litter compounds in later phases of decomposition at higher altitudes.

In $\mathrm{N}$ limited systems in the temperate and boreal regions, litter material with a high C-to-N ratio typically accumulates $\mathrm{N}$ for longer periods of time (Berg, 2014). In contrast to this pattern, the results presented in Chapter 2 show for the investigated tropical montane ecosystems, which are co-limited by both $\mathrm{N}$ and $\mathrm{P}$ (Homeier et al., 2012), that despite the initially very low $\mathrm{N}$ concentration in the litter there was generally no increase in the amount of litter $\mathrm{N}$ except within the first 6 months in litter at $1000 \mathrm{~m}$. After 6 months the amount of $\mathrm{N}$ uniformly decreased in the litter material at all altitudes suggesting that $\mathrm{N}$ from the litter material was mobilized and transported out of the litterbags, although the $\mathrm{C}$-to- $\mathrm{N}$ ratio of litter markedly exceeded values at which net mineralisation is assumed to occur (Hodge et al., 2000). This suggests that plants rely on mycorrhizal fungi improving $\mathrm{N}$ capture by growing into leaf and root litter material. Indeed, the great majority of tree species in the investigated tropical montane forest are associated with AM fungi (Haug et al., 2004; Kottke et al., 2004) which are known to stimulate $\mathrm{N}$ uptake by plants, improve decomposition by interacting with the microbial community (Coleman, 1994; Hodge et al., 2001; Koller et al., 2013b,c) and form pronounced extra-radical mycelia growing into decomposing litter material (Marschner et al., 2001; Camenzind \& Rillig, 2013). We suggest that, as previously reported by Koller et al. (2013a) for temperate ecosystems, the $C$ input via AM fungi enables the microbial community in 
tropical montane forests to obtain $\mathrm{N}$ from the litter material, despite the high C-to-N ratio (Koller et al., 2013a). In fact, it has been shown that protozoa can mobilise microbially fixed $\mathrm{N}$ by grazing on bacteria irrespective of litter C-to- $\mathrm{N}$ ratios and that AM fungi effectively translocate the mobilised $\mathrm{N}$ to the host plant (Koller et al., 2013b). Notably, Krashevska et al. (2008) already suggested testate amoebae, a major group of protists at the investigated study site, to be driven by the availability of bacteria and fungi as food source.

We expected, in accordance with the results of the study presented in Chapter 2 and 3, that the microbial biomass would decrease in the absence of root derived resources. However, this was not the case in the study presented in Chapter 4, suggesting that AM fungi and the microbial community not always benefit from their mutualistic interaction but instead compete for resources. Leigh et al. (2011) described antagonistic interactions between AM fungi and bacteria in a laboratory experiment. Especially in P limited systems, the extra-radical hyphae of AM fungi and the saprotrophic microbial community are assumed to compete for $\mathrm{P}$ (Leigh et al., 2011; Nottingham et al., 2013). This suggests that at our study sites, where both $P$ and $N$ are in limited supply (Homeier et al., 2012), antagonistic interactions between mycorrhizal fungi and saprotrophic microorganisms are pronounced. This is also supported by the exclusion of mycorrhizal hyphae and roots resulting in an increase in basal respiration and in trend also in $\mathrm{C}_{\text {mic }}$, suggesting that mycorrhizal fungi in fact suppressed the activity of saprotrophic microorganisms. As documented above, however, these interactions did not translate into changes in litter decomposition and litter $\mathrm{N}$ dynamics.

The results presented in Chapter 2 further indicate that variations in the microbial community in the litter material are closely linked to the different stage of the decomposition process. From temperate and boreal regions the structure and functioning of the microbial community in decomposing litter material is known to change during decomposition, parallel to changes in the chemical composition of the litter material (Scheu \& Parkinson, 1995; Berg \& McClaugherty, 2008). While in the studied tropical montane rainforest the origin and therefore quality of the litter material affected the microbial community only early during decomposition; site specific conditions, i.e. altitude, became more important at later stages. The microbial biomass data therefore indicates that after depletion of easily decomposable litter compounds in the first phase of decomposition, the activity of the microbial community slows down or even cease in the second phase between 12 and 36 months at the 2000 and $3000 \mathrm{~m}$ altitude, due to resource availability being at a minimum. Resumption of litter decomposition at these altitudes in the third phase after 36 months suggests that a novel microbial community able to decompose condensed recalcitrant litter compounds including lignin took over. This pattern indicates, considering the results presented in Chapter 4, that at higher altitudes the interaction between mycorrhizal fungi and saprotrophic microorganisms varies during decomposition, from initial competition for easily 
decomposable litter compounds to a greater importance of saprotrophic microorganisms able to decompose recalcitrant litter compounds at later stages.

\section{Soil microarthropod abundance and diversity}

Similar to previous studies (Illig et al., 2010; Rillig et al., 2013), the results presented in Chapter 3 and 4 of this thesis demonstrated that changes in biotic and abiotic variations along the altitudinal gradient not only influence decomposition rates, but also soil microarthropod abundance and diversity. Unexpectedly, however, the pattern in which the abundance of microarthropods varied along the altitudinal gradient was not consistent in the studies presented in Chapter 3 and 4 . Previous studies (Maraun et al., 2008; Illig et al., 2010; Rillig et al., 2013) and the study presented in Chapter 3 reported that soil microarthropod abundance and diversity decreased with increasing altitude and these changes were attributed to variations in the microbial community and the decreasing quality and diversity of belowground plant-derived resources (Maraun et al., 2008; Illig et al., 2010; Rillig et al., 2013). In contrast, results presented in Chapter 4 showed microarthropod abundance to peak at the intermediate altitude (i.e. $2000 \mathrm{~m}$ ) and Oribatida diversity not to differ between 1000 and $2000 \mathrm{~m}$. As stated above, the sampling in the study presented in Chapter 4 was performed during a different season than that in the study presented in Chapter 3 suggesting that seasonal variations, such as drought and drought related changes in plant - soil fauna interactions, were responsible for the low abundance of microarthropods and low Oribatida diversity at the $1000 \mathrm{~m}$ site. While variations in plant functional traits are known to vary with seasonal changes in precipitation and humidity (Ortiz et al., 2006; Bendix et al., 2006), virtually nothing is known on the influence of these seasonal changes on the soil fauna community in tropical montane ecosystems. In addition to abundance and diversity also the community structure of Oribatida varied strongly with altitude, with only few species occurring at each of the three altitudes, rather, most species occurred at one altitude only (endemic species). This pattern highlights the strong turnover of species with altitude, i.e. high $\beta$-diversity. Also, the percentage of sexual Oribatida species and individuals increased with increasing altitude consistent with earlier reports (Maraun et al., 2013) and fitting the model proposed by Scheu and Drossel (2007) predicting sexual species to be favoured by density-dependent factors such as competition for resources. Indeed, as indicated by the decrease in density of microarthropods and the decline in resource quality at higher altitude, resource competition is likely to increase with altitude at our study sites.

The results presented in Chapter 3 also demonstrated that the abundance of Oribatida and Collembola varied between leaf and root litter. Typically, the density of soil mesofauna declines with soil depth (Berg et al., 1998). The abundance of Oribatida fit this pattern, whereas the density of Collembola did not show such a uniform response. The lower density of Oribatida in root as 
compared to leaf litter might be due to the previously discussed lower quality of root as compared to leaf litter (Bloomfield et al., 1993; Berg \& McClaugherty, 2008); however, it may also be related to root litterbags being exposed deeper in the soil whereas leaf litterbags were placed on the soil surface. Sminthuridae also showed the expected pattern, reaching higher abundances in leaf litter. Their distribution is conform to the fact that they are closely associated with plants and at least in part live as herbivores feeding on higher plants, algae and lichens (Chahartaghi et al., 2005). The other investigated Collembola groups, Megalothorax, Isotomidae and Entomobryidae, typically were more abundant in root litterbags. Potentially, these Collembola taxa preferentially colonize deeper soil layers to evade larger predators such as spiders and beetles as they predominantly forage in the porous space of leaf litter (Wagner et al., 2003).

As presented in Chapter 3 the abundance and diversity of the investigated soil animal taxa was strongly influenced by the degree to which the litter material was decomposed. As previously discussed, decomposition rates and the microbial community composition varied strongly with time and although interrelationships between litter decomposition and soil mesofauna have been widely studied (Heneghan et al., 1999; Scheu, 2002; Kampichler \& Bruckner, 2009; Castanho et al., 2012) little is known on long-term changes in density and diversity of mesofauna taxa in decomposing leaf litter. In the study presented in Chapter 3 the abundance of both decomposer groups, Oribatida and Collembola, as well as Oribatida diversity varied strongly and in similar directions with sampling dates, suggesting that processes occurring during litter decomposition influence both taxa in a similar way as well as indicating that the availability of resources and niches changes during decomposition. Both Collembola and Oribatida interact closely with bacteria and fungi and comprise a wide spectrum of species of different trophic levels including primary and secondary decomposers and in part also predators (Scheu, 2002; Schneider et al., 2004; Chahartaghi et al., 2005; Heidemann et al., 2014). In recent years an increasing number of studies in temperate forests highlighted the importance of root-derived resources for fuelling soil food webs (Schneider et al., 2005; Pollierer et al., 2007; Remen et al., 2010; Zieger et al., 2015). The results of this thesis indicate, however, that the availability of root and litter derived resources as well as the importance of these energy pathways varies with the previously discussed three phases of decomposition. Similar to these three phases of decomposition, in the study presented in Chapter 3, the abundance of the investigated decomposer groups and of Oribatida diversity also followed a three phase-pattern and these changes were closely associated with changes in the speed of litter decomposition and the changes in microorganisms presented in Chapter 2. As discussed above, during the early phase of decomposition microorganisms presumably efficiently exploited labile litter resources, i.e. easily available litter compounds used by root-associated microorganisms including mycorrhiza. Surprisingly, in the study presented in Chapter 3 microarthropods were unable to benefit from this 
microbial community and their abundance did only increase after 12 months of decomposition, suggesting that towards the end of the first phase of decomposition more resources were becoming available to the soil fauna community. In part this pattern might be explained by the presence of plant secondary compounds such as phenols in the litter material which are broken down during the first phase of litter decay. Further, as previously discussed, mycorrhizal fungi and saprotrophic microorganisms presumably compete for easily available nutrients, and the low abundance of microarthropods in the early phase of decomposition might be related to the dominance of mycorrhizal fungi which, according to recent evidence, are little consumed by microarthropods (Potapov \& Tiunov, 2015). The results of the study presented in Chapter 4, however, highlights the importance of root-derived resources in fuelling the soil food web in the investigated tropical montane rainforest, with exclusion of roots and mycorrhiza not only reducing the amount of resources available for Oribatida but also the number of trophic niches in the system. Also, recent studies conducted in the temperate region suggest that especially Oribatida species heavily rely on root-derived resources (Schneider et al., 2005; Pollierer et al., 2007; Remen et al., 2010; Zieger et al., 2015). However, the results presented in Chapter 3 show that the density of soil fauna increased after 12 months of litter decomposition, i.e. the end of the first phase (see also Chapter 2) and sampling time if the study presented in Chapter 4. Potentially, at this stage mycorrhizal fungi no longer dominate the microbial community and microarthropods benefit from the shift towards the dominance of saprotrophic microorganisms at the end of the first phase of litter decay. However, thereafter, in the second phase of decomposition from 12 to 24 months, soil mesofauna abundance of virtually all of the studied mesofauna groups as well as Oribatida species diversity declined parallel to changes in microbial community composition, declining microbial biomass and litter decomposition slowing down or even coming to halt. Presumably, resource and niche availability in litter declined during this decomposition stage with the level of resources available being insufficient to sustain microbial and mesofauna populations. As discussed above, at the third stage of decomposition when recalcitrant compounds are being attacked by saprotrophic microorganisms, such as lignin-degrading fungi, detritivore mesofauna species became more abundant. This may be due to either saprotrophic microorganisms themselves serving as food or the litter material becoming more palatable due to more intensive enzyme attack (Bardgett, 2005). As indicated by earlier studies, increased palatability of litter resources at later stages of decay might be due to the breakdown of phenolic litter compounds (Coulis et al., 2009) indicating again that the importance of energy pathways varies over the course of decomposition. We therefore suggest that at the early stage of decomposition the mesofauna community is fuelled mainly via the root pathway, whereas at later stages more resources are gained from decomposing litter material and/or associated saprotrophic microorganisms. 


\section{Conclusions}

Long term decomposition patterns as well as the composition of the microarthropod community in tropical montane rainforests are at least for the most part not caused by differences in litter quality, but rather by site specific conditions as well as different trophic interactions between plants and the belowground community. Results of the present thesis suggest that the accumulation of dead organic material at higher altitudes and the formation of thick $F$ layers in tropical montane rainforests is caused by reduced or ceasing decomposition rates in both leaf and root litter in a second phase of decomposition between 12 and 36 months and slow resumption of litter decomposition after this phase. Presumably, the accumulation of leaf and root litter at high altitudes and therefore the formation of thick layers of organic material (F-layer) inhibits positive interactions between the microbial community in the upper litter layer and the mineral soil and these conditions lead to closer trophic linkage between plants and the decomposer community at higher altitudes. Decomposition stage was also an important factor driving the microarthropod community and variations in their abundance and diversity were closely associated with changes in microorganisms. Presumably, in the nutrient limited Andean tropical montane rainforests mycorrhizal fungi and saprotrophic microorganisms compete for litter-derived resources with mycorrhizal fungi being able to suppress the activity of saprotrophic microorganisms early during litter decay. Results of the studies presented in this thesis highlight the importance of root-derived resources in fuelling soil food webs, with exclusion of roots and mycorrhiza not only reducing the amount of resources available but also the number of trophic niches in the system. Surprisingly, microarthropods are unable to benefit from the flourishing of microorganisms at the early stage of decomposition, potentially due to the presence of plant secondary compounds such as phenols and the suppression of saprotrophic microorganisms by mycorrhizal fungi. At later stages of decomposition when recalcitrant compounds are being attacked by saprotrophic microorganisms, such as lignin-degrading fungi, microarthropods are becoming more abundant and diverse either due to benefiting from feeding on these microorganisms or by indirectly benefiting from the conditioning of the litter by microbial enzyme production.

The studies presented in this thesis advanced the understanding of regulatory forces controlling decomposition processes as well as microarthropod abundance and diversity in tropical Andean ecosystems and contributed to reconciling the ongoing debate on the relative importance of the root and litter energy channel in fuelling soil food webs. They help to disentangling how plant derived resources impact the belowground community structure, decomposition processes and the capture of nutrients by plants and microarthropods from decomposing litter and root associated mycorrhiza over long-term decomposition processes. 


\section{References}

Bardgett RD. 2005. The Biology of Soil: A community and ecosystem approach. Oxford: Oxford University Press.

Bendix J, Homeier J, Cueva EO, Emck P, Breckle S-W, Richter M, Beck E. 2006. Seasonality of weather and tree phenology in a tropical evergreen mountain rain forest. International journal of biometeorology 50: 370-384.

Berg B. 2014. Decomposition patterns for foliar litter - A theory for influencing factors. Soil Biology and Biochemistry 78: 222-232.

Berg MP, Kniese JP, Bedaux JJM, Verhoef HA. 1998. Dynamics and stratification of functional groups of micro- and mesoarthropods in the organic layers of a scots pine forest soil. Biol Fertil Soils 26: 268-284.

Berg B, McClaugherty C. 2008. Plant Litter: Decomposition, Humus Formation, Carbon Sequestration. Berlin, Heidelberg: Springer Verlag.

Bloomfield J, Vogt KA, Vogt DJ. 1993. Decay rate and substrate quality of fine roots and foliage of two tropical tree species in the Luquillo Experimental Forest, Puerto Rico. Plant and Soil 150: 233-245.

Butenschoen O, Krashevska V, Maraun M, Marian F, Sandmann D, Scheu S. 2014. Litter mixture effects on decomposition in tropical montane rainforests vary strongly with time and turn negative at later stages of decay. Soil Biology and Biochemistry 77: 121-128.

Camenzind T, Rillig MC. 2013. Extraradical arbuscular mycorrhizal fungal hyphae in an organic tropical montane forest soil. Soil Biology and Biochemistry 64: 96-102.

Castanho CT, Lorenzo L, de Oliveira AA. 2012. The importance of mesofauna and decomposition environment on leaf decomposition in three forests in southeastern Brazil. Plant Ecology 213: $1303-1313$.

Chahartaghi M, Langel R, Scheu S, Ruess L. 2005. Feeding guilds in Collembola based on nitrogen stable isotope ratios. Soil Biology and Biochemistry 37: 1718-1725.

Cleveland CC, Reed SC, Keller AB, Nemergut DR, O'Neill SP, Ostertag R, Vitousek PM. 2014. Litter quality versus soil microbial community controls over decomposition: a quantitative analysis. Oecologia 174: 283-294.

Coleman DC. 1994. The microbial loop concept as used in terrestrial soil ecological studies. Microbial ecology 28: 245-250.

Coulis M, Hättenschwiler S, Rapior S, Coq S. 2009. The fate of condensed tannins during litter consumption by soil animals. Soil Biology and Biochemistry 41: 2573-2578.

Coûteaux M-M, Bottner P, Berg B. 1995. Litter decomposition, climate and litter quality. Trends in Ecology and Evolution 10: 63-66.

Cusack DF, Chou WW, Yang WH, Harmon ME, Silver WL. 2009. Controls on long-term root and leaf litter decomposition in neotropical forests. Global Change Biology 15: 1339-1355.

Haug I, Lempe J, Homeier J, Weiß M, Setaro S, Oberwinkler F, Kottke I. 2004. Graffenrieda emarginata (Melastomataceae) forms mycorrhizas with Glomeromycota and with a member of the Hymenoscyphus ericae aggregate in the organic soil of a neotropical mountain rain forest. Canadian Journal of Botany 82: 340-356. 
Heidemann K, Ruess L, Scheu S, Maraun M. 2014. Nematode consumption by mite communities varies in different forest microhabitats as indicated by molecular gut content analysis. Experimental and Applied Acarology 64: 49-60.

Heneghan L, Coleman DC, Zou X, Crossley DA, Haines BL. 1999. Soil microarthropod contributions to decomposition dynamics: Tropical-temperate comparisons of a single substrate. Ecology 80: 1873-1882.

Hodge A, Campbell CD, Fitter AH. 2001. An arbuscular mycorrhizal fungus accelerates decomposition and acquires nitrogen directly from organic material. Nature 413: 297-299.

Hodge A, Robinson D, Fitter A. 2000. Are microorganisms more effective than plants at competing for nitrogen? Trends in Plant Science 5: 304-308.

Homeier J, Hertel D, Camenzind T, Cumbicus NL, Maraun M, Martinson GO, Poma LN, Rillig MC, Sandmann D, Scheu S, et al. 2012. Tropical Andean forests are highly susceptible to nutrient inputs-Rapid effects of experimental $\mathrm{N}$ and $\mathrm{P}$ addition to an Ecuadorian montane forest. PloS one 7: e47128.

Illig J, Norton RA, Scheu S, Maraun M. 2010. Density and community structure of soil- and barkdwelling microarthropods along an altitudinal gradient in a tropical montane rainforest. Experimental and Applied Acarology 52: 49-62.

Illig J, Schatz H, Scheu S, Maraun M. 2008. Decomposition and colonization by micro-arthropods of two litter types in a tropical montane rain forest in southern Ecuador. Journal of Tropical Ecology 24: 157-167.

Kampichler C, Bruckner A. 2009. The role of microarthropods in terrestrial decomposition: a metaanalysis of 40 years of litterbag studies. Biological reviews of the Cambridge Philosophical Society 84: 375-389.

Koller R, Robin C, Bonkowski M, Ruess L, Scheu S. 2013a. Litter quality as driving factor for plant nutrition via grazing of protozoa on soil microorganisms. FEMS Microbiology Ecology 85: 241-250.

Koller R, Rodriguez A, Robin C, Scheu S, Bonkowski M. 2013b. Protozoa enhance foraging efficiency of arbuscular mycorrhizal fungi for mineral nitrogen from organic matter in soil to the benefit of host plants. New Phytologist 199: 203-211.

Koller R, Scheu S, Bonkowski M, Robin C. 2013c. Protozoa stimulate N uptake and growth of arbuscular mycorrhizal plants. Soil Biology and Biochemistry 65: 204-210.

Kottke I, Beck A, Oberwinkler F, Homeier J, Neill D. 2004. Arbuscular endomycorrhizas are dominant in the organic soil of a neotropical montane cloud forest. Journal of Tropical Ecology 20: 125-129.

Krashevska V, Bonkowski M, Maraun M, Ruess L, Kandeler E, Scheu S. 2008. Microorganisms as driving factors for the community structure of testate amoebae along an altitudinal transect in tropical mountain rain forests. Soil Biology and Biochemistry 40: 2427-2433.

Leigh J, Fitter AH, Hodge A. 2011. Growth and symbiotic effectiveness of an arbuscular mycorrhizal fungus in organic matter in competition with soil bacteria. FEMS microbiology ecology 76 : 428-438.

Leuschner C, Moser G, Bertsch C, Röderstein M, Hertel D. 2007. Large altitudinal increase in tree root/shoot ratio in tropical mountain forests of Ecuador. Basic and Applied Ecology 8: 219230. 
Maraun M, Fronczek S, Marian F, Sandmann D, Scheu S. 2013. More sex at higher altitudes: Changes in the frequency of parthenogenesis in oribatid mites in tropical montane rain forests. Pedobiologia 56: 185-190.

Maraun M, Sandmann D, Krashevska V, Norton RA, Scheu S. 2008. Soil Fauna. In: Beck E,, In: Bendix J,, In: Kottke I,, In: Makeschin F,, In: Mosandl R, eds. Gradients in a Tropical Mountain Ecosystem of Ecuador (Ecological Studies 198). Springer-Verlag Berlin, 181-192.

Marschner P, Crowley DE, Lieberei R. 2001. Arbuscular mycorrhizal infection changes the bacterial $16 \mathrm{~S}$ rDNA community composition in the rhizosphere of maize. Mycorrhiza 11: 297-302.

Nottingham AT, Turner BL, Winter K, Chamberlain PM, Stott A, Tanner EVJ. 2013. Root and arbuscular mycorrhizal mycelial interactions with soil microorganisms in lowland tropical forest. FEMS microbiology ecology 85: 37-50.

Ortiz EC, Homeier J, Breckle S-W, Bendix J, Emck P, Richter M, Beck E. 2006. Seasonality in an evergreen tropical mountain rainforest in southern Ecuador. Ecotropica 12: 69-85.

Pollierer MM, Langel R, Körner C, Maraun M, Scheu S. 2007. The underestimated importance of belowground carbon input for forest soil animal food webs. Ecology letters 10: 729-736.

Potapov AM, Tiunov A V. 2015. Stable isotope composition of mycophagous collembolans versus mycotrophic plants: Do soil invertebrates feed on mycorrhizal fungi? Soil Biology and Biochemistry 93: 115-118.

Remen C, Fransson P, Persson T. 2010. Population responses of oribatids and enchytraeids to ectomycorrhizal and saprotrophic fungi in plant-soil microcosms. Soil Biology and Biochemistry 42: 978-985.

Rillig MC, Camenzind T, Gawlik J, Haug I, Maraun M, Sandmann D, Scheu S. 2013. Diversity in soil fungi, protists and microarthropods. In: Bendix J,, In: Beck E,, In: Bräuning A, In: Makeschin $F$, In: Mosandl R, In: Scheu $S$, In: Wilke W, eds. Ecosystem services, biodiversity and environmental change in a tropical mountain ecosystem of southern Ecuador. Springer Verlag, Berlin, Heidelberg, 81-92.

Scheu S. 2002. The soil food web: structure and perspectives. European Journal of Soil Biology 38: $11-20$.

Scheu S, Drossel B. 2007. Sexual reproduction prevails in a world of structured resources in short supply. Proceedings of the Royal Society B: Biological Sciences 274: 1225-1231.

Scheu S, Parkinson D. 1995. Successional changes in microbial biomass, respiration and nutrient status during litter decomposition in an aspen and pine forest. Biology and Fertility of Soils 19: $327-332$.

Schneider K, Renker C, Maraun M. 2005. Oribatid mite (Acari, Oribatida) feeding on ectomycorrhizal fungi. Mycorrhiza 16: 67-72.

Schneider K, Renker C, Scheu S, Maraun M. 2004. Feeding biology of oribatid mites: a minireview. Phytophaga 14: 247-256.

Wagner JD, Toft S, Wise DH. 2003. Spatial stratification in litter depth by forest-floor spiders. The Journal of Arachnology 31: 28-39.

Zieger SL, Eissfeller V, Maraun M, Scheu S. 2015. Incorporation of carbon and nitrogen from leaf litter differing in structural compounds into soil microarthropods of a deciduous forest. Pedobiologia 58: 219-227. 


\section{Acknowledgements}

Mein erster Dank geht an Stefan Scheu. Danke, dass ich als Teil deiner Arbeitsgruppe forschen und arbeiten durfte. Danke für die vielen interessanten Gespräche und dein unglaubliches Fachwissen, das meine Arbeit geformt und bereichert hat. Vielen Dank für die Möglichkeit so oft nach Ecuador und zum Milbenkurs nach Ohio zu reisen und dafür, dass du immer ein offenes Ohr für alle Fragen und Probleme hattest. Besonders danken möchte ich dir auch dafür, dass du mich auch während meiner Arbeitsunfähigkeit unterstütz und ermutigt hast.

Vielen Dank an Mark Maraun für deine Unterstützung bei meiner Arbeit, vor allem bei der Statistik und für deine Tipps bei meinen ersten Schritten auf dem Weg zum Bestimmen der Oribatiden.

Ich danke meinen drei Betreuern, Stefan Scheu, Mark Maraun und Ulrich Brose für die Unterstützung während meiner Promotion und die Verlängerungen meiner Studienzeit.

Mein ganz besonderer Dank geht an meine Kollegin und Freundin Dorothee Sandmann, für die wundervollen gemeinsamen Aufenthalte in Ecuador und die gemeinsame Zeit im Büro. Danke, dass du immer ein offenes Ohr für meine Fragen hattest und mich immer ermutigt und unterstützt hast. Vor allem danke ich dir für deinen ungeheuren Enthusiasmus beim Bestimmen der Oribatiden. Ohne deinen Elan und dein Wissen wäre der Berg an neuen Arten niemals zu bewältigen gewesen.

Vielen Dank an alle Mitglieder der AG Scheu für die schöne gemeinsame Zeit, die angenehme Atmosphäre, die gute Zusammenarbeit und eure Hilfe in den verschiedensten Lebenslagen. Besonders danken möchte ich Melanie Maraun für die tolle gemeinsame Zeit im Büro, Garvin Schulz für die Unterstützung nicht nur bei technischen Fragen, Sarah Zieger dafür, dass sie alle meine dummen Fragen zur Promotion beantwortet hat, der ganzen Sozialraum-Mittagsessen-Gesellschaft für viele lustige und interessante Gespräche und eigentlich allen anderen auch :)

Besonderen Dank auch an Andrea Lambertz, Christel Fischer, Ingrid Kleinhans, Susanne BöningKlein, Guido Humpert, Andrea Gräbe-Treger, Dora Volovei und Dieter Nünchert ohne deren unermüdliche Arbeit die ganze Arbeitsgruppe vermutlich im Chaos versinken würde.

Danke an alle Helfer, Bachelor- und Masterstudenten, die mit mir nach Ecuador gereist sind und mir bei der Feldarbeit mit Rat und Tat zur Seite gestanden haben: Jens Bast, Christian Bluhm, Stephan Remin, Garvin Schulz, Stefanie Fronczek, Linda Gervinga, Tobias Lauermann, Lucas Marian, Kristina Röben, Kristina Richter, Dana Augustin, Fionn Clissmann, Pablo Ramirez und Laura Sanchez. Vor allem vielen Dank an meine erfahrenen Kolleginnen im Ecuadorprojekt, Valentyna Krashevska und Dorothee Sandmann. Ohne eure Vorabreiten und Ratschläge wäre meine Arbeit unmöglich gewesen. 
Ein großes Dankeschön auch an alle, die als Hiwis für mich stundenlang Blätter und Wurzeln putzen mussten, ich weiß, was ich euch angetan habe und ich hoffe ihr habt keine bleibenden mentalen Schäden davon getragen. Ich bin euch zu ewigem Dank verpflichtet.

Danke auch an alle Mitglieder der Forschergruppe 816 und an alle meine "Mitbewohner" auf der Forschungsstation in Ecuador. Ihr habt die Zeit dort unvergesslich gemacht und mir über diverse Sprachbarrieren hinweg geholfen. Danke an Felix Matt und Jörg Zeilinger für eure Unterstützung bei sämtlichen Behördengängen in Ecuador und an Marias Küchenteam für das leckere Essen.

Ich danke auch meinen Freunden hier in Göttingen. Danke an die Mädels aus unserer GNTM Gruppe für viele lustige Abende und an Tobi für eine Freundschaft die auch nach dem WG Leben besteht. Ein ganz besonders großes Dankeschön an meine besten Freundinnen Doro und Melanie, für die tolle gemeinsame Zeit hier in Göttingen, für lange Gespräche und Ratschläge in allen Lebenslangen und dafür, dass ihr immer für mich da seid und mich immer wieder mit gemeinsamen Ausflügen und Heimwerker Wochenenden vom Promotionsstress abgelenkt habt.

Danke an meine Freundinnen aus meiner alten Heimat, Feli, Suzy und Emmy die mich seit so vielen Jahren begleiten und deren Freundschaft ich um nichts in der Welt missen möchte. Danke, dass ihr immer für mich da seid und es auch immer sein werdet. Danke auch an Natalie für eine Freundschaft die mich geprägt hat und die ich nie vergessen werde.

Ein ganz besonderes Dankeschön geht an meinen besten Freund und Mann Lucas. Du bist das Beste was ich bei meinen Reisen nach Ecuador gefunden habe. Danke für die vielen Stunden in denen du meine Arbeit Korrektur gelesen hast, für deine Hilfe beim Formatieren und generell bei allem was mit Technik zu tun hat. Danke, dass du dich in der Zeit meiner Genesung so liebevoll um mich gekümmert und mich aufgebaut hast. Ganz besonders danken möchte ich dir dafür, dass du mich immer unterstützt und motiviert hast und mich auch dann ertragen hast, wenn ich ein extrem anstrengendes Nervenbündel war. Und vor allem danke dafür, dass du immer an mich glaubst und mich genauso liebst wie ich bin.

Mein letzter und größter Dank geht an meine Familie und vor allem an meine Eltern Helga und Roland. Danke, dass ihr immer für mich da seid, mir immer vertraut und mich in allem unterstützt und motiviert was ich tue. Danke Mama, dass du nicht nur meine Mutter sondern vor allem meine Freundin bist, immer weißt wie du mich mit einem „dummen“ Spruch zum Lachen bringst und vor allem immer ein Vorbild für mich bist. Danke Ben, dass du mein Interesse für die Natur geweckt und gefördert hast, dass ich immer Quatsch mit dir machen kann und dass ich dank dir immer eine lustige Geschichte zu erzählen habe. Ohne euch wäre ich nicht der Mensch der ich heute bin. 


\section{List of Publications}

Maraun M, Fronczek S, Marian F, Sandmann D, Scheu S. 2013. More sex at higher altitudes: Changes in the frequency of parthenogenesis in oribatid mites in tropical montane rain forests. Pedobiologia 56: 185-190.

Butenschoen O, Krashevska V, Maraun M, Marian F, Sandmann D, Scheu S. 2014. Litter mixture effects on decomposition in tropical montane rainforests vary strongly with time and turn negative at later stages of decay. Soil Biology and Biochemistry 77: 121-128.

Ermilov SG, Bayartogtokh B, Sandmann D, Marian F, Maraun M. 2013a. New and little known species of oribatid mites of the family Haplozetidae (Acari, Oribatida) from Ecuador. ZooKeys 57: 43-57.

Ermilov SG, Sandmann D, Marian F, Maraun M. 2013b. New oribatid mites of the genera Machadobelba and Campachipteria Acari: Oribatida) from Ecuador. Systematic \& Applied Acarology 18: 145-152.

Ermilov SG, Sandmann D, Marian F, Maraun M. 2013c. Two new oribatid mite species of the genus Gittella from Ecuador. Spixiana 39: 1-8.

Ermilov SG, Sandmann D, Marian F, Maraun M. 2013d. Oribatid mites of the superfamily Oppioidea from Ecuador (Acari : Oribatida). Systematic \&Applied Acarology 18: 218-224.

Ermilov SG, Sandmann D, Marian F, Maraun M. 2013e. Three new species of the genus Sternoppia (Acari: Oribatida: Sternoppiidae) from Ecuador. Zootaxa 3641: 565-576.

Ermilov SG, Sandmann D, Marian F, Maraun M. 2013f. New taxa and new records of oribatid mites of the family Galumnidae (Acari: Oribatida) from Ecuador. Zootaxa 3700: 259-270.

Ermilov SG, Sandmann D, Marian F, Maraun M. 2013g. Two new species of oribatid mites of the genus Truncozetes (Acari, Oribatida, Epactozetidae) from Ecuador. ZooKeys 31: 23-31.

Ermilov SG, Sandmann D, Marian F, Maraun M. 2013h. Three new species of oribatid mites (Acari, Oribatida) from Ecuador. Acarologia 53: 111-123.

Ermilov SG, Sandmann D, Marian F, Maraun M. 2013i. Perscheloribates paratzitzikamaensis $n$. sp., with supplementary descriptions of Scheloribates elegans and Monoschelobates parvus (Acari, Oribatida, Scheloribatidae) from Ecuador. Acarologia 53: 429-437.

Ermilov SG, Sandmann D, Marian F, Maraun M. 2014. New species of oribatid mites of the genera Hermannobates and Rhynchoribates (Acari: Oribatida: Hermanniellidae, Rhynchoribatidae) from Ecuador. Systematic and Applied Acarology 19: 313-321. 


\section{Thesis Declarations}

\section{Declaration of the author's own contribution to manuscripts with multiple authors}

The experiment presented in Chapter 2 and 3 was set up by Dorothee Sandmann and Valentyna Krashevska. Samples of the different sampling dates were collected and prepared for analysis by me with the help of Dorothee Sandmann, Jens Bast, Christian Bluhm, Tobias Lauermann, Linda Grevinga, Kristina Richter and Dana Augustin. The experiment presented in Chapter 4 was set up and samples were collected by Lucas Marian and myself with additional help from Kristina Röben and Fionn Clissmann. Linda Grevinga helped determine part of the soil fauna community analysed in Chapter 3 and 4 . Measurements of $\mathrm{C}$ and $\mathrm{N}$ contents for Chapter 2 and 4 were performed by Ute Schlonsog in the laboratory of Prof. Dr. Christoph Leuschner (Göttingen/Germany). Ergosterol measurements for Chapter 2 were performed by Gabriele Dormann in the laboratory of Prof. Dr. Rainer Georg Joergensen (Kassel/Witzenhausen/Germany).

I am the first author of all manuscripts; I have analysed the data, written the manuscripts, developed the main ideas, created tables, figures and appendices and contributed significantly to the study design. The study design of each study was developed in the framework of the DFG Research Unit "Biodiversity and Sustainable Management of a Megadiverse Mountain Ecosystem in South Ecuador" (FOR 816). All persons contributing to the manuscripts have been named. All coauthors contributed to finalizing the manuscripts.

The cover-photographs were all taken by me or my helpers in Ecuador (see acknowledgements) except for the EM pictures of Oribatida used on the third page and in the cover picture for Chapter 3, which were taken by Mark Maraun and Garvin Schulz under the supervision of Dorothea Hause-Reitner from the Faculty of Geoscience and Geography, University and Goettingen. 


\section{Plagiarism declaration}

I, Franca Marian, declare that I have written this doctoral thesis independently. All persons contributing to the manuscripts have been named (see above). All sentences or passages quoted from other people's work have been specifically acknowledged by clear crossreferencing.

I have not submitted this thesis in any form for another degree at any university or institution.

Franca Marian

Göttingen, June 2016 